\title{
A Legislative Review of U.S. Aquaculture: A State Analysis Relating to West Virginia
}

Ryan M. Benninger

West Virginia University

Follow this and additional works at: https://researchrepository.wvu.edu/etd

\section{Recommended Citation}

Benninger, Ryan M., "A Legislative Review of U.S. Aquaculture: A State Analysis Relating to West Virginia" (2011). Graduate Theses, Dissertations, and Problem Reports. 3455.

https://researchrepository.wvu.edu/etd/3455

This Thesis is protected by copyright and/or related rights. It has been brought to you by the The Research Repository @ WVU with permission from the rights-holder(s). You are free to use this Thesis in any way that is permitted by the copyright and related rights legislation that applies to your use. For other uses you must obtain permission from the rights-holder(s) directly, unless additional rights are indicated by a Creative Commons license in the record and/ or on the work itself. This Thesis has been accepted for inclusion in WVU Graduate Theses, Dissertations, and Problem Reports collection by an authorized administrator of The Research Repository @ WVU. For more information, please contact researchrepository@mail.wvu.edu. 


\title{
A Legislative Review of U.S. Aquaculture: A State Analysis Relating to West Virginia
}

\author{
Ryan M. Benninger \\ Thesis Submitted to the Davis College of Agriculture, Natural Resources and Design \\ at West Virginia University \\ in partial fulfillment of the requirements for the degree of
}

\author{
Master of Science \\ In \\ Agricultural Resource Economics \\ Thesis Committee: \\ Jerald J. Fletcher, Ph.D., (Chair) \\ Kenneth J. Semmens, Ph.D. \\ Peter V. Schaeffer, Ph.D. \\ Daniel J. Miller, Ph.D. \\ Fonda L. Holehouse, J.D.
}

Division of Resource Management

Morgantown, West Virginia (2011)

Keywords: Regulatory, Legislative, Aquaculture Development, West Virginia 


\section{ABSTRACT \\ A Legislative Review of U.S. Aquaculture: A State Analysis Relating to West Virginia \\ Ryan M. Benninger}

This case study was designed and presented to allow a reader-friendly" environment for aquaculture industry inquiry, specifically to pertain to West Virginia's recent surge in industry development. The sample for this thesis consisted of aquaculture producing states located within the continental U.S. The research design was qualitative descriptive that evaluated the legislative environments for each state aquaculture industry to ultimately pass recommendations for West Virginia. Of the states surveyed, it was found that 26 states enacted development acts for respective industries; 19 states were found to further develop with strategic plans. The greatest constraint discovered during this project was a lack of credible, consistent information. Not only does the U.S. aquaculture industry require more working manuscripts such as this case study, but also the U.S. Agriculture sector as a whole must strive to better inform its members and public alike.

Like the majority of the states surveyed for this case study, West Virginia has accomplished multiple achievements during its quest to develop its aquaculture industry. Having completed a legislative development act, additional work towards an on-going strategic plan should be the next goal for the State. While many question the place of regulation in state agricultural activities, a general theme must be remembered. Regulation acknowledges and protects a given industry, such as aquaculture, and it provides a foundational framework by which a respective industry can prosper competitively. In closing, research that frames regulation's impact on agricultural pursuits, such as aquaculture, must be the focus for the future as increasing domestic production must occur to meet a growing demand for sustenance. 


\section{ACKNOWLEDGMENTS}

The author would like to express his appreciation to the U.S. Department of Agriculture and the Division of Resource Management, Davis College of Agriculture, Natural Resource, \& Design of West Virginia University for financial grant assistance which made this research project possible. The author would specifically like to thank the following individuals for their direct involvement with this Master's degree: Cameron Hackney Ph.D., Jerald J. Fletcher Ph.D, Fonda L. Holehouse J.D., Peter V. Schaeffer Ph.D., Kenneth Semmens Ph.D., \& Daniel J. Miller Ph.D.

Michael Dougherty, Ph.D and Harry Boone Jr., Ph.D., are to be mentioned for their participation with editing and formatting of this thesis. Nyakundi Michieka was crucial in his assistance during the economic analysis phase. Also to note, Gloria Nestor and Vishesh Maskey were crucial during the graphical interpretation phase.

The author would like to take the opportunity to give special thanks to his parents: J. Michael Benninger and Barbara R. Benninger, specifically for their continued support. Following, the author would like to acknowledge the support of his wife, Claire AbrenicaBenninger, for her love and support as well.

Additionally, the author would like to acknowledge the administrative staff, which includes the following: Ms. Melanie Jimmie, Ms. Ellen Hartley-Smith, and Ms. Lisa Lewis; and also the graduate students that comprise the Division of Resource Management. Lastly, the author would like to thank the individual aquaculture representatives from the states evaluated for their input and desire to promote aquaculture in the U. S. The completion of this project hinged on the information provided. 


\section{TABLE OF CONTENTS}

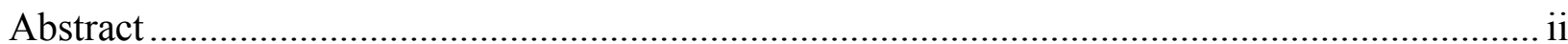

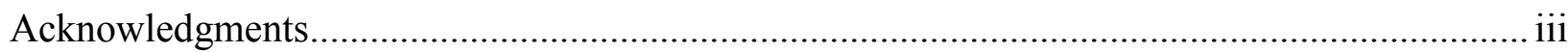

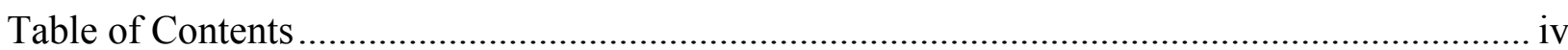

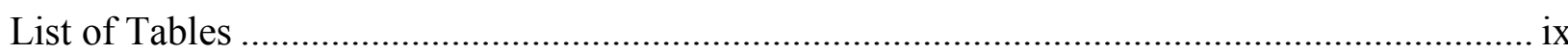

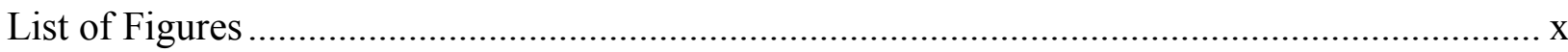

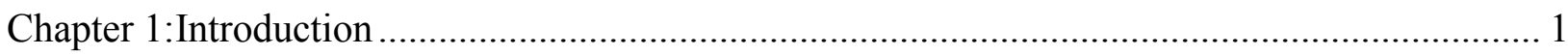

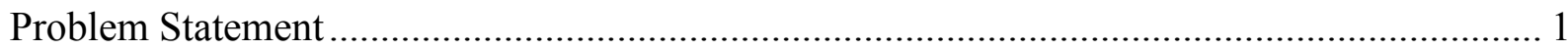

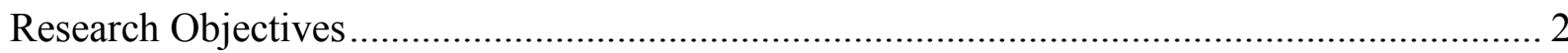

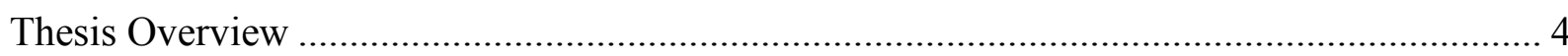

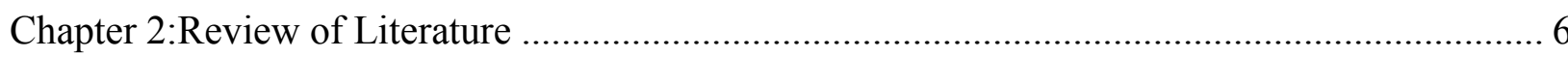

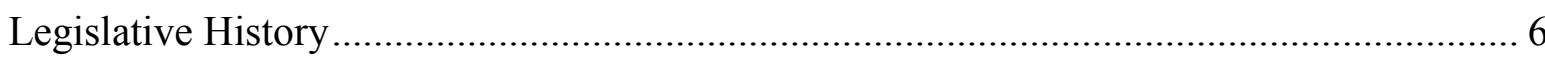

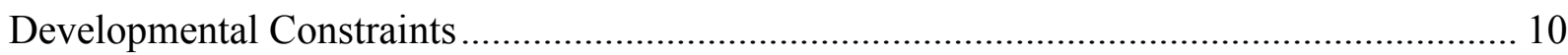

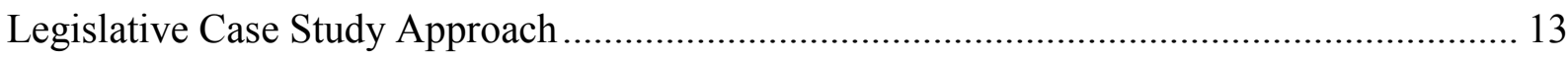

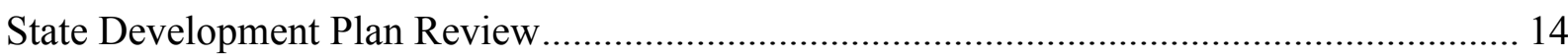

Regulatory Ranking Approach ................................................................................. 15

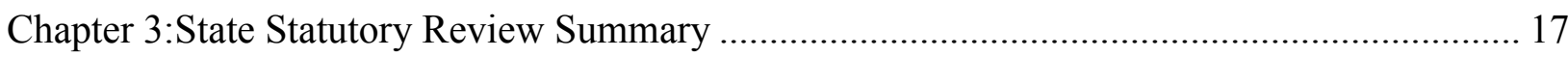

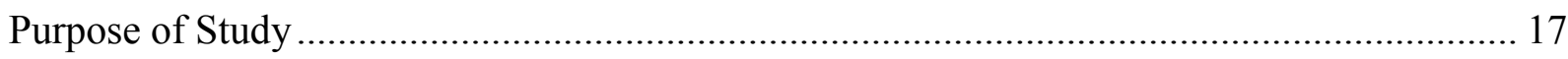

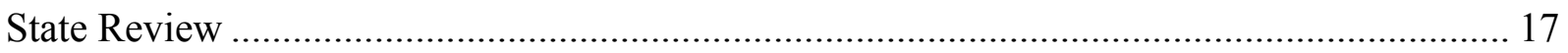

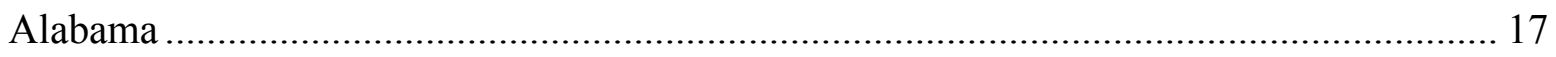

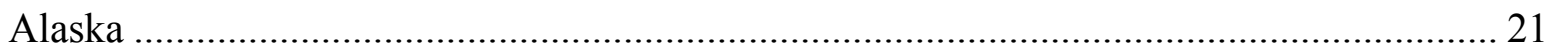

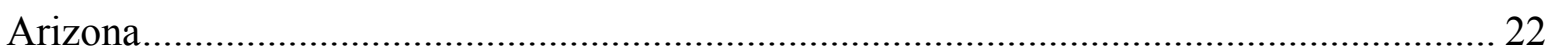

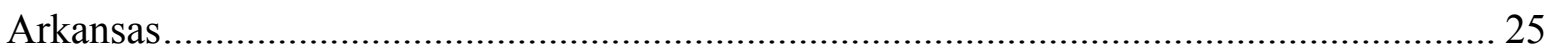

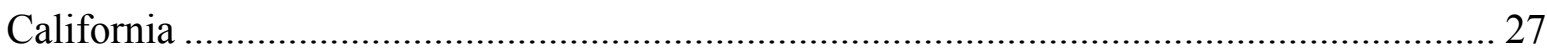

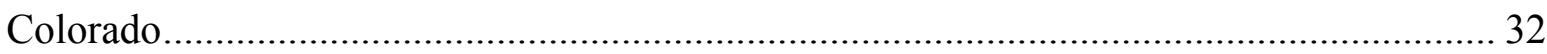

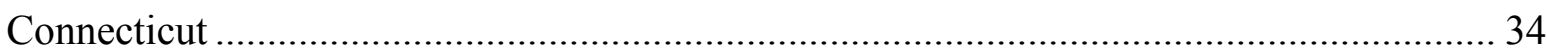

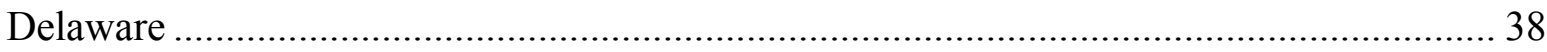

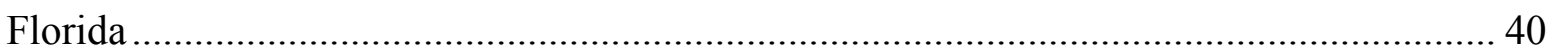

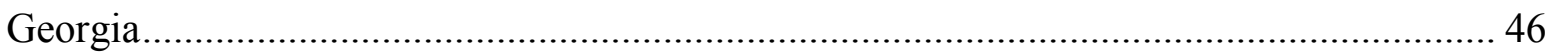

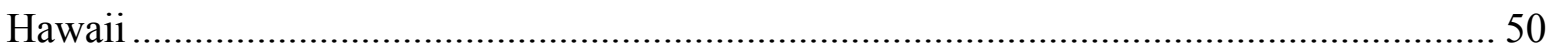

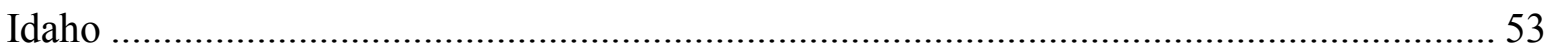

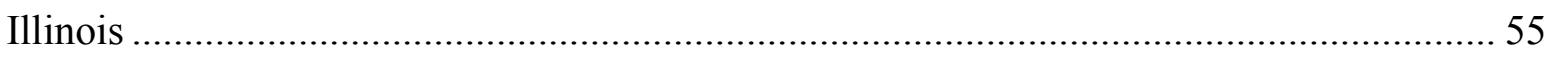

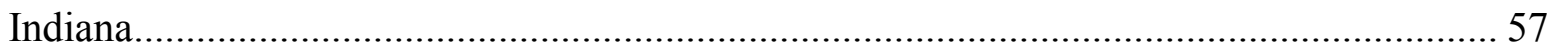




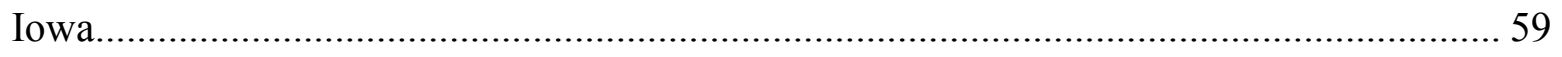

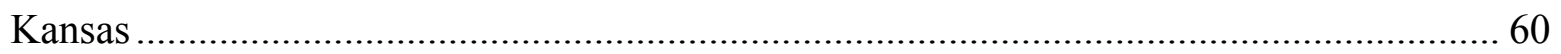

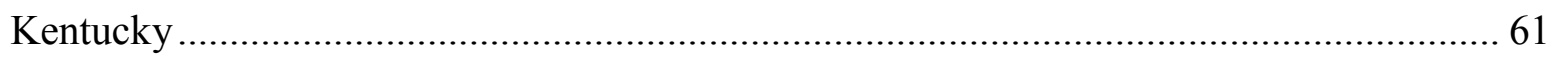

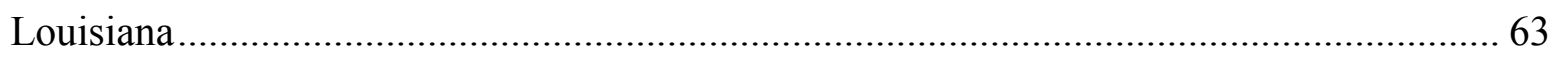

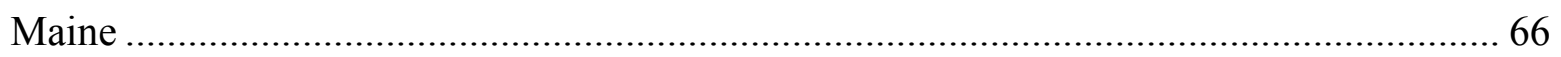

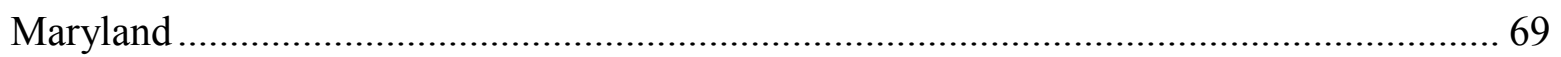

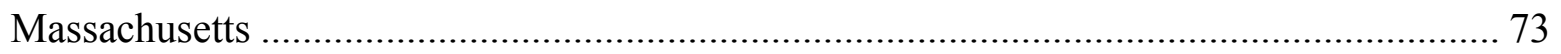

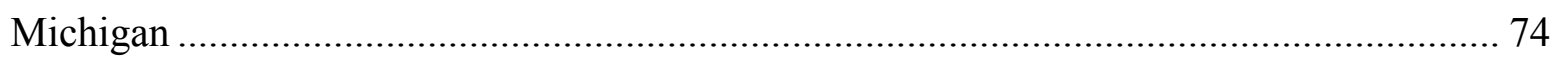

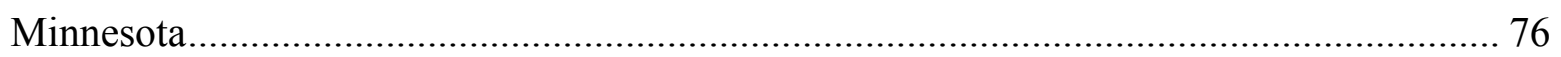

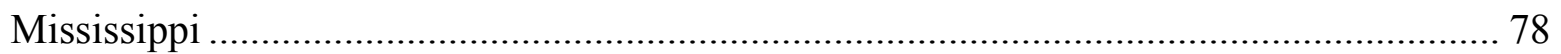

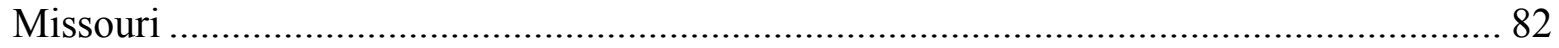

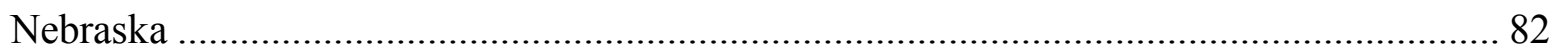

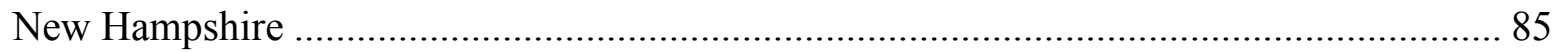

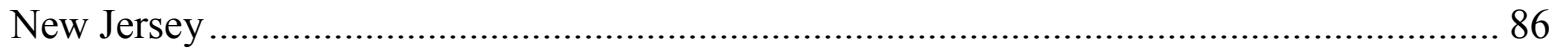

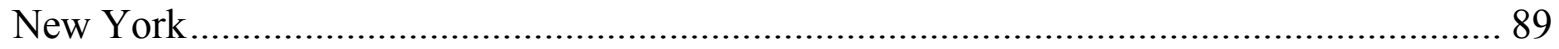

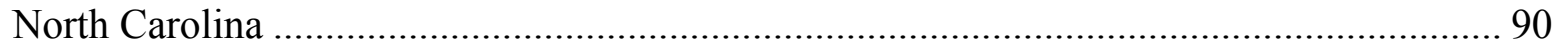

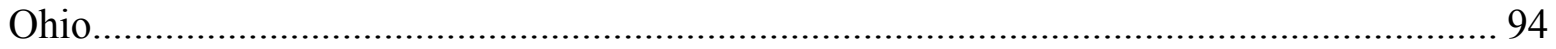

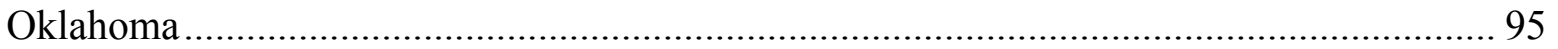

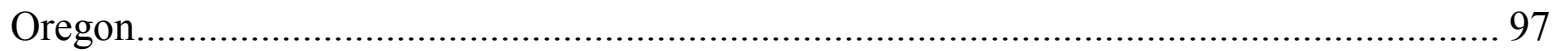

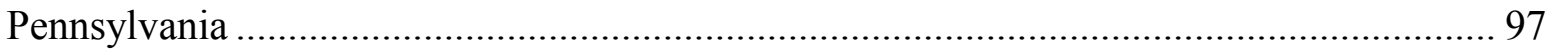

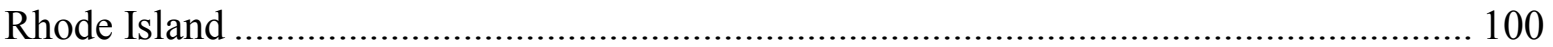

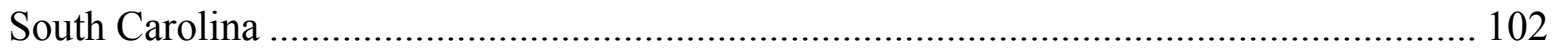

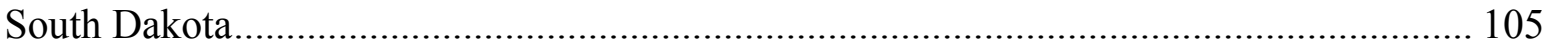

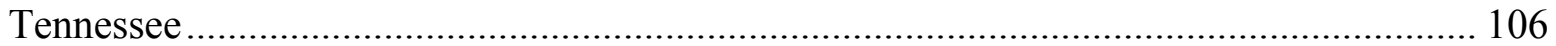

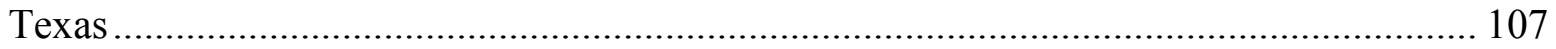

Utah

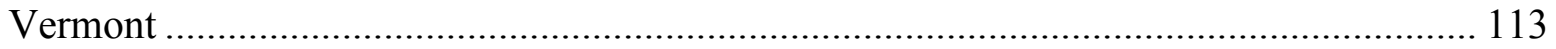

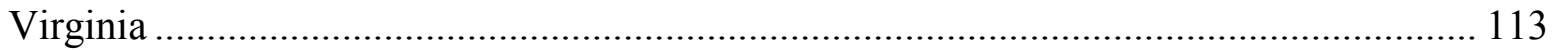

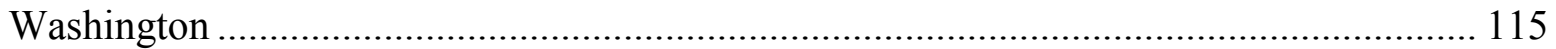

West Virginia ..................................................................................................... 119

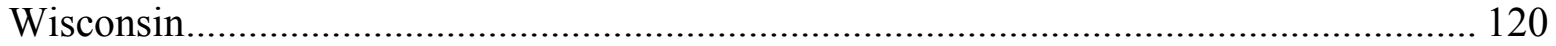

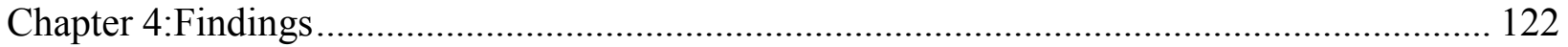

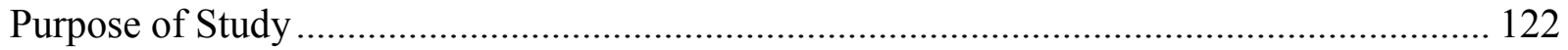

Two-Phase Economic Analysis ....................................................................................... 122 


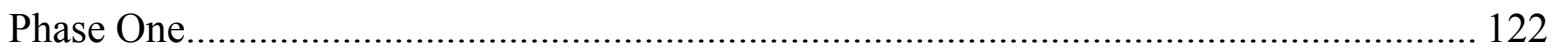

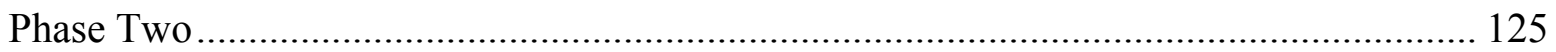

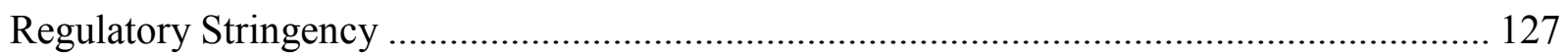

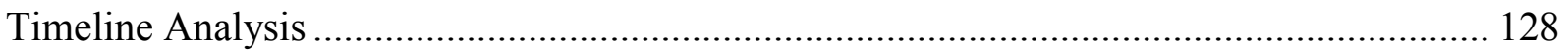

Chapter 5:Summary, Conclusions, \& Recommendations........................................................... 130

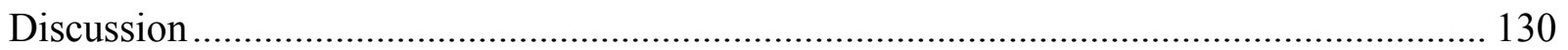

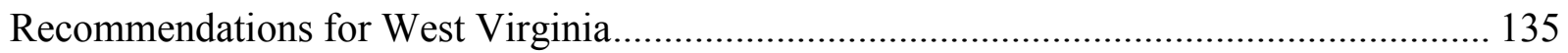

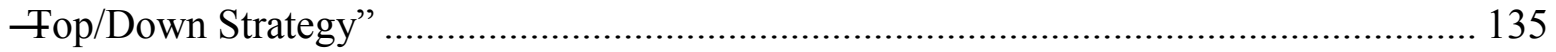

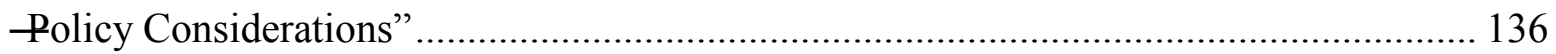

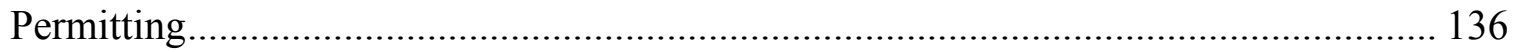

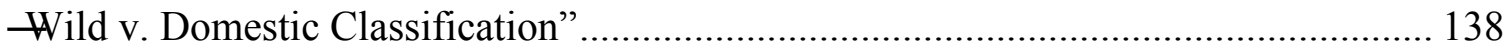

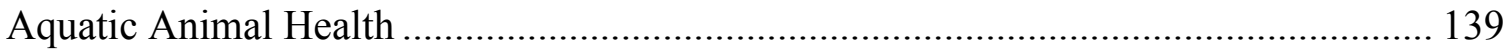

Incentivizing Economic Development......................................................................... 139

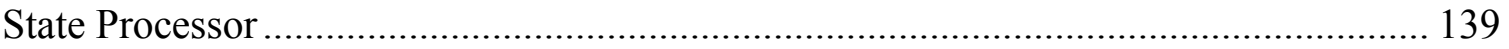

-Creative Niche Market Promotion" .............................................................................. 140

West Virginia's Reality" ........................................................................................ 141

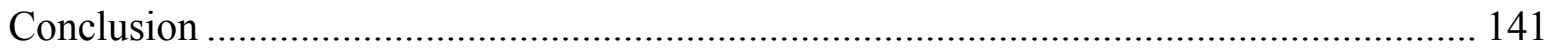

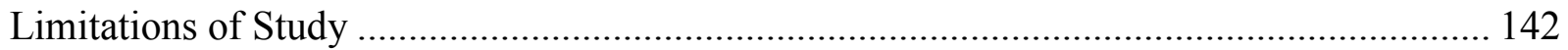

Further Research Considerations ................................................................................ 143

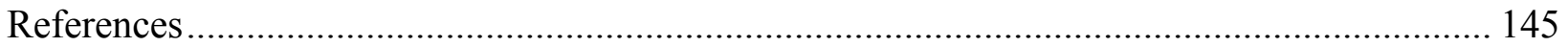

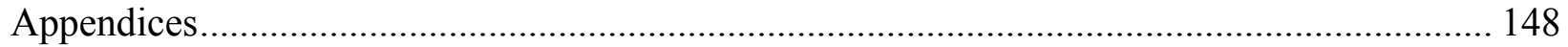

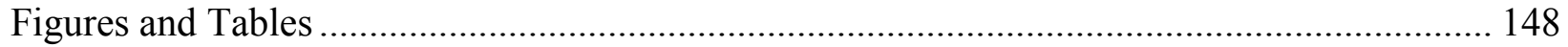

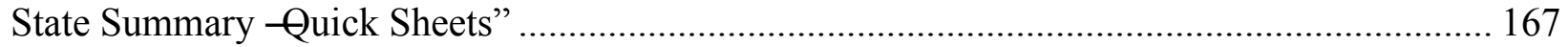

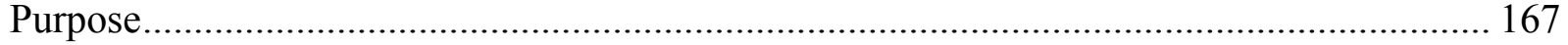

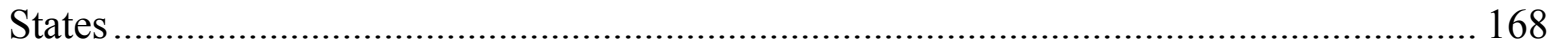

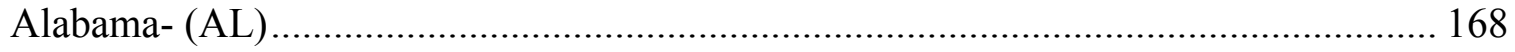

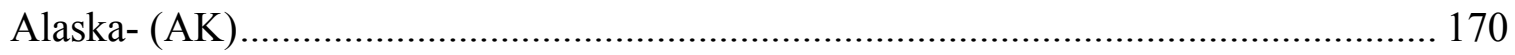

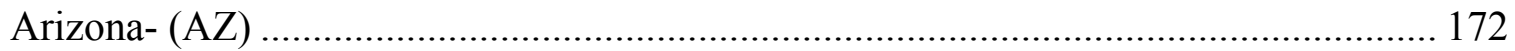

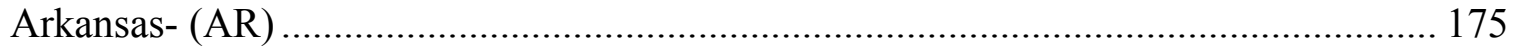

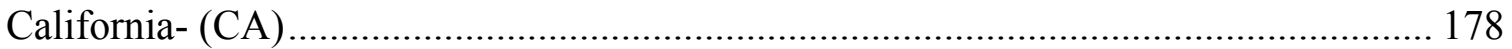

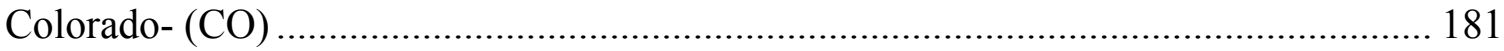

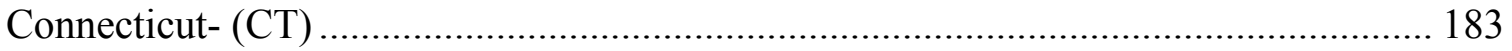

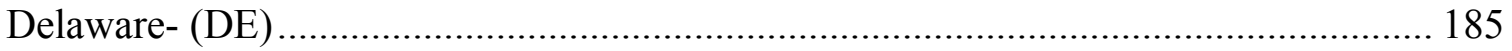

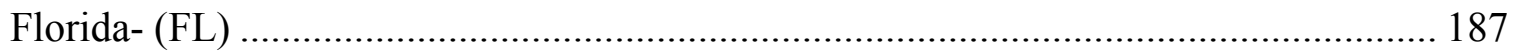




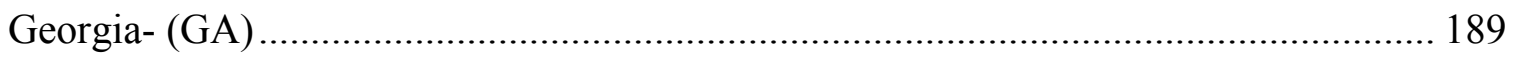

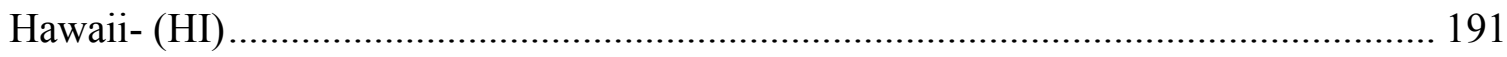

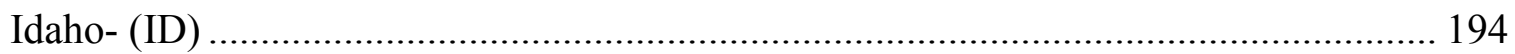

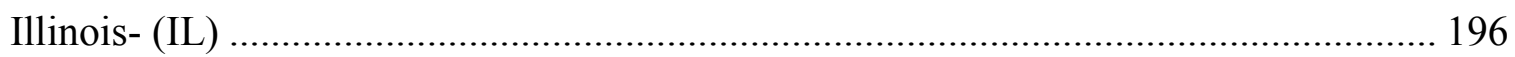

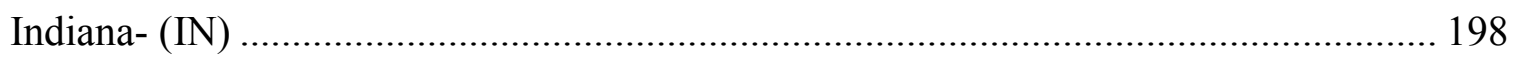

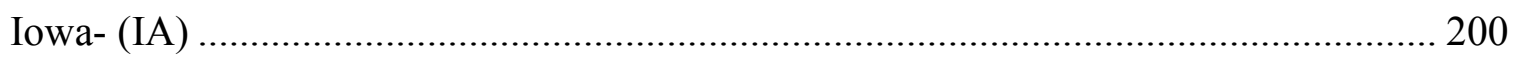

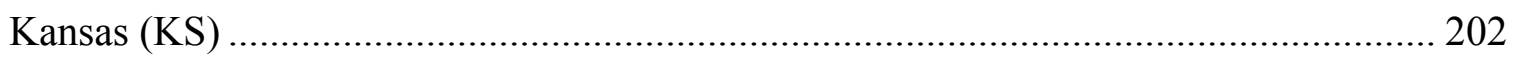

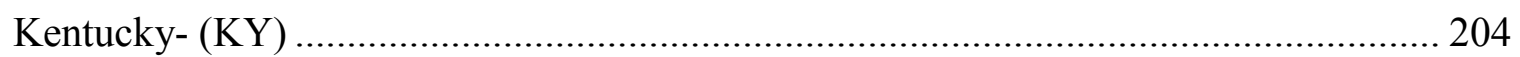

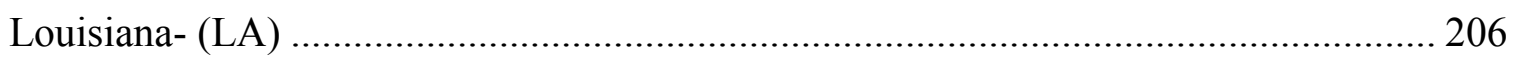

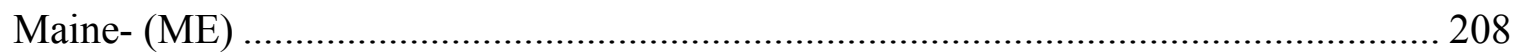

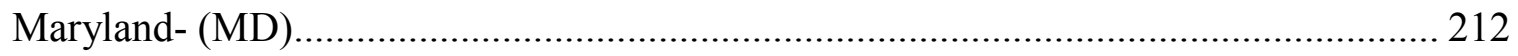

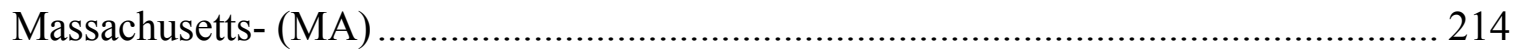

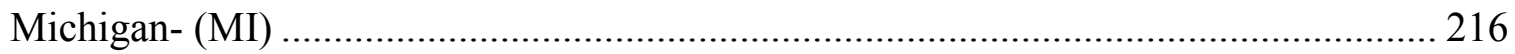

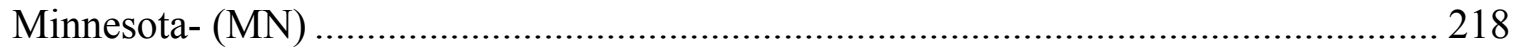

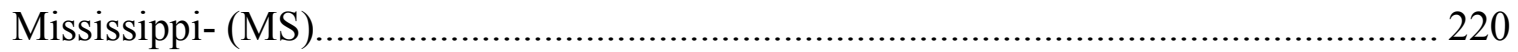

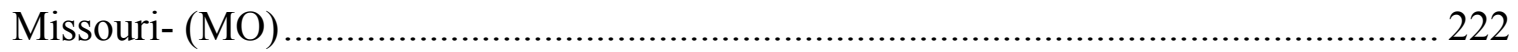

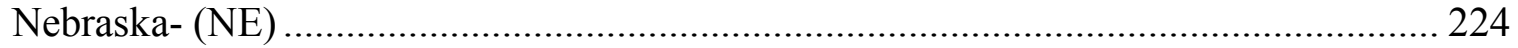

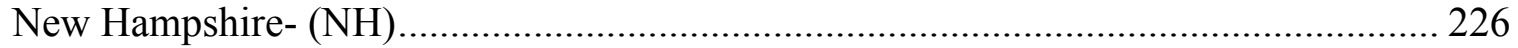

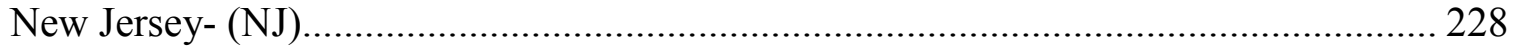

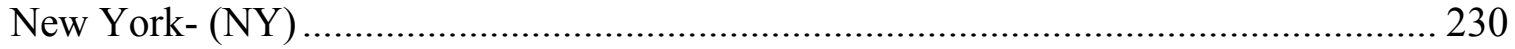

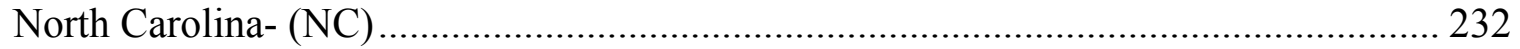

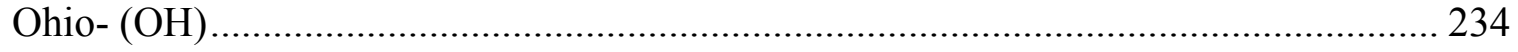

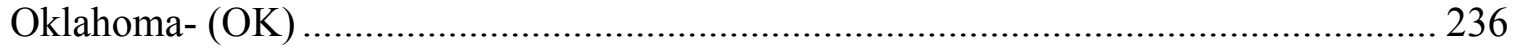

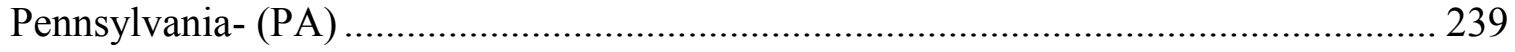

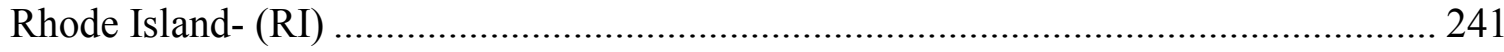

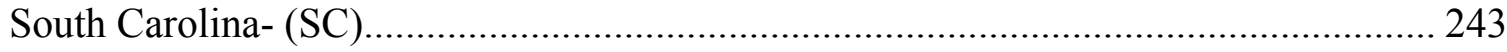

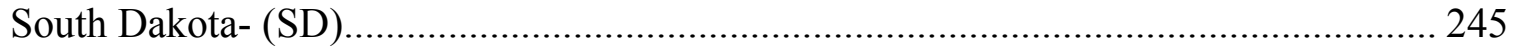

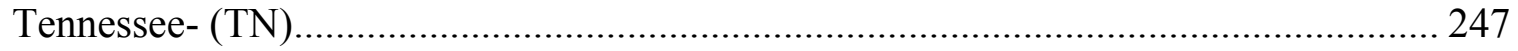

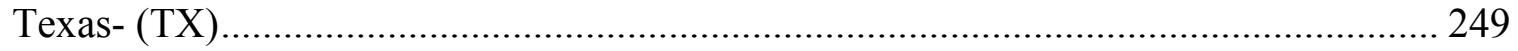

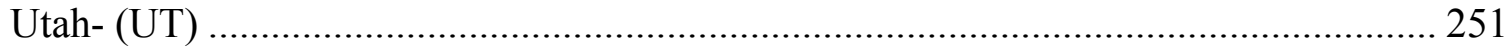

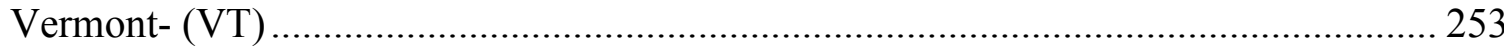

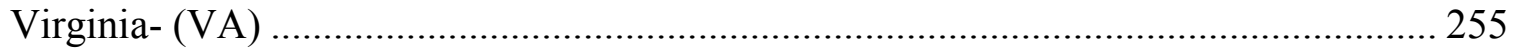

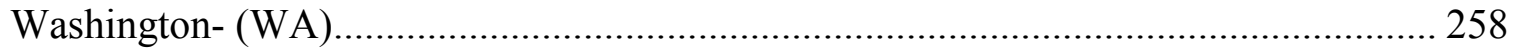

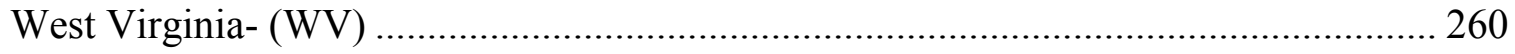


Wisconsin-(WI). 


\section{LIST OF TABLES}

Table 1: Individual State Contribution Dataset (1998-2005) ............................................. 157

Table 2: Aquaculture Value Per Farm (1998-2005) .......................................................... 158

Table 3: Top 5 Aquaculture Producing States in U.S. Dataset (2005) .................................. 159

Table 4: Bottom 5 Aquaculture Producing States in U.S. Dataset (2005).............................. 159

Table 5: Top 5 Aquaculture Producing States in U.S. Dataset (1998) ................................... 159

Table 6: Bottom 5 Aquaculture Producing States in U.S. Dataset (1998).............................. 159

Table 7: Percent Growth in Aquaculture Producing Farms (1998-2005) ................................ 160

Table 8: Percent Growth in Production Value for U.S. Aquaculture (1998-2005) .................. 160

Table 9: GIS Percent Change in U.S. Aquaculture (1998-2005) .......................................... 161

Table 10: Raw Wirth and Luzar 2000 Dataset for Regulatory Stringency .............................. 162

Table 11: Individual U.S. State Aquaculture Regulatory Time Dataset ................................. 163

Table 12: State Summary Review Dataset (A.) ................................................................. 164

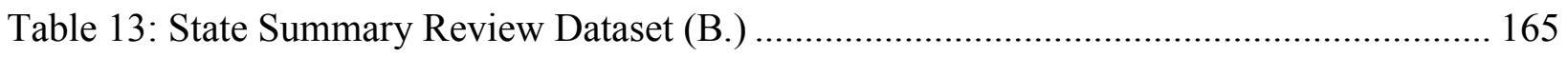

Table 14: State Summary Review Dataset (C.) ................................................................... 166 


\section{LIST OF FIGURES}

Figure 1: State Contribution to Overall Production (2005) ................................................ 148

Figure 2: State Contribution to Overall Production (1998) ................................................. 149

Figure 3: Percent Change in Number of Aquaculture Farms (1998 and 2005) ...................... 150

Figure 4: Percent Change in Aquaculture Farm Production Value (1998 and 2005)............... 151

Figure 5: Top Five Aquaculture Producing States in U.S. (2005) ........................................ 152

Figure 6: Bottom Five Aquaculture Producing States in U.S. (2005) ................................... 152

Figure 7: Top Five Aquaculture Producing States in U.S. (1998) ........................................ 153

Figure 8: Bottom Five Aquaculture Producing States in U.S. (1998) ................................... 153

Figure 9: U.S. Aquaculture Percent Change in Total Number of Farms (1998-2005) .............. 154

Figure 10: U.S. Aquaculture Farm Value Percent Change in Production Growth (1998-2005) 155

Figure 11: Regulatory Scale Measure of Individual State Aquaculture 200 (Wirth and Luzar) 156 


\section{CHAPTER 1}

\section{INTRODUCTION}

\section{PROBLEM STATEMENT}

Regulation generally is a combination of organizations, rules, and sanctions that result in behaviors to provide orderly market structure, industry accountability, and overall economic stability, while promoting an overall public interest. Aquaculture development in the United States is heavily influenced by regulation often occurring at both the federal and state levels. The central problem with the idea of regulation over aquaculture is that it is perceived to be a detriment to development. Many times, stifled development results from improper regulation, which amounts to unnecessary, duplicitous rules or legislation, or the lack of a regulatory structure. The occurrence of constrained development prevents the U.S. from reaching its maximum production potential for aquaculture development. Comparing the relationship between regulation and aquaculture industry development is not straightforward, therefore, research must occur.

Across the nation, aquaculture received formal recognition in 1980 when Federal statutory acknowledgment and protections were afforded to the industry. ${ }^{1}$ Since the Act was codified, states have been urged to develop their own industries. The State of West Virginia, unlike other thriving states, has taken approximately three decades to develop its industry by

\footnotetext{
1 National Aquaculture Policy, Planning, and Development Act, 16 U.S.C. § 2801 et seq. Added by Act of Sept. 26, 1980, P. L. 96-362, 94 Stat. 1198.
} 
enacting legislation in $2010 .^{2}$ Currently, West Virginia is in the process of development, but the State is far from reaching its full development potential.

This thesis presents a case study designed to identify the current state of aquaculture legislation and regulation across the United States. This manuscript represents the first time that legislation for the entire industry has been reviewed and presented in one report. Before effective regulatory development may occur, this evaluation must first take place in order to understand the current state of aquaculture in this country.

\section{RESEARCH OBJECTIVES}

Following formal acknowledgement of aquaculture in the United States by Congress in the early 1980s, research into development constraints has been conducted. Nowhere has there been a thorough review of the legislative atmosphere of aquaculture throughout the country. This document serves as an extension of already completed research while collating over three decades worth of legislation.

The initial discussion over the design of this research project took place over the course of more than a year and a half to pinpoint a scope of necessity that would assist the West Virginia Aquaculture Advisory Board promulgated in late 2010. This purpose of this document is to aid the Board in developing a strategic plan for the industry in this state. This research acts as a case study that reviews the current legislative status of the United States aquaculture industry as a whole. By reviewing what current development practices have been implemented throughout other states, West Virginia would serve to benefit from the experience of other developed industries. Thus, the state potentially could specifically tailor efficient legislation, reducing developmental constraints previously faced in other states, by selecting a methodology

\footnotetext{
2 West Virginia Aquaculture Development Act, SB 236, (2010). http://www.legis.state.wv.us/Bill Status/bills text.cfm?billdoc=SB236\%20SUB1.htm\&yr=2010\&sesstype=RS\&i=23 $\underline{6}$
} 
to maximize the production potential for the uniqueness of the state of West Virginia. Beyond its usefulness for West Virginia, this document will hopefully be a research manuscript for other potential aquaculturists and other states looking to promote the industry.

The research was conducted by utilizing Westlaw, an online legal library, which provides a non-annotated access to all state statutes referencing aquaculture in the continental U.S. Westlaw allowed for a historical perspective of state aquaculture as well as current up-to-date legislation. The non-annotated search for aquaculture returned over 1700 statutory references for the states. The initial review began looking to answer seven main questions:

1. Does the state have development legislation?

2. Does the state have an aquaculture advisory broad, council or other administrative committee?

3. Which regulatory agency is appointed as the tead" or principal agency?

4. Does the state have an aquaculture coordinator position?

5. How does the state address aquatic waste disposal?

6. How does the state handle aquatic animal health management?

7. How does the state incorporate higher education during the industry development phase?

These seven questions are perceived to be an indicator of an efficient aquaculture industry. Pending the initial review through Westlaw, contact was made to NASAC to obtain a list of contacts for each state's industry. Multiple telephone and email contacts were made with various parties over the duration of the research period, in order to obtain a more personal point of view for the individual state industries.

In addition to the research that was completed, appendices contain summaries that serve as quick references for states. The appendices are included in place of graphs that usually accompany this type of research. The summary sheets are useful to the industry because they provide a concise, up-to-date notation of state legislative status. 


\section{THESIS OVERVIEW}

This thesis is presented in five chapters beginning with this introduction. The thesis presents a case study of current U.S. Aquaculture legislation to emphasize the different approaches taken by individual states. The research will be utilized by the State of West Virginia as its progresses with its industry development. A brief description of the remaining chapters follows.

Chapter Two consists of background information on the industry. A comprehensive legislative history is outlined. Also, this chapter comprises the literature review for the thesis.

The individual state review is contained in Chapter Three. While some analysis is contained in the text, the majority is summarized and found in Chapter Four. The legislative information was obtained by researching Westlaw, an online legal library. The administrative rules, which represent a form of law promulgated through an agency rather than through a state legislature, were also referenced for each state by reviewing individual state codes. Reports from state industries and bulletins from state regulatory websites also accompany the legislative review. Telephone conferences were attempted to all state $\mathrm{NASAC}^{3}$ contacts and the information gained is included in Chapter Three. In many instances, additional contact to industry producers or other representatives was made to familiarize the author with the individual state in question.

Chapter Four presents the economic analysis conducted to summarize the research by drawing correlations between changes in state regulations and known production values for the years 1998 and 2005. The data was obtained by reviewing the $\mathrm{NASS}^{4}$ census data released in 2007.

\footnotetext{
${ }^{3}$ National Association of State Aquaculture Coordinators ("NASAC")

${ }^{4}$ National Agricultural Statistics Service, associated with the USDA.
} 
Chapter Five contains the conclusions of this research. A discussion describing a simplified development strategy for West Virginia is outlined. Limitations affecting the research will be elaborated. Further research is advised. 


\section{CHAPTER 2}

\section{REVIEW OF LITERATURE}

\section{Legislative History}

In 1978, Newton published a law review article concerning emerging aquaculture issues that provides an historical perspective relating aquaculture to agriculture, dating back to 1966 (Newton, 1978). According to Newton, aquaculture was first recognized as a separate industry under the National Sea Grant College and Program Act of 1966. ${ }^{5}$ The 1966 Act declared aquaculture as a land-based form of agriculture that could substantially benefit the United States. ${ }^{6}$ Under the Act, Newton indicated that the National Science Foundation, (NSF), was the first federal authority to oversee aquaculture, where their role was to administer funding for research and development (Newton, 1978). By 1970, aquaculture was then transferred to the Department of Commerce, to be administered by the National Oceanographic and Atmospheric Administration, (NOAA). ${ }^{7}$ Following the transfer in 1970, U.S. marine aquaculture is regulated by the NOAA Aquaculture Program. ${ }^{8}$

By 1976, the Act had been amended, subsequently deleting any reference noting aquaculture." Congress acted in response to the statutory amendment to the 1966 Act, noting that aquaculture required federal recognition to continue to foster development (U.S. Commision on Ocean Policy, 2002). It addressed this concern by including aquaculture legislation under the National Agriculture Research, Extension, and Teaching Policy Act of $1977 .{ }^{9}$

\footnotetext{
${ }^{5}$ National Sea Grant College and Program Act of 1966, 33 U.S.C. $§ 1121$ et seq.

${ }^{6}$ Id. at 33 U.S.C. $\S 1121$ (c).

7 “1970 Reorganization Plan No.4, sec 1(d), eff. Oct.3, 1970, 35 Fed Reg. 15627, 84 Stat 2090.”

${ }^{8}$ National Oceanic and Atmospheric Administration (NOAA), Aquaculture Program.

${ }^{9}$ National Agriculture Research, Extension, and Teaching Policy Act of 1977, 7 U.S.C. $\S 3101$ et seq. Added by P.L. 95-113, Eff. Sept. 29, 1977.
} 
Aquaculture's involvement was described under the Agriculture Research Act because it is an industry that operates much like agriculture (U.S. Department of Agriculture (USDA), 2002). This point is predicated on the notion that species are selected to be bred to improve existing stocks, that the growth of agricultural organisms is heavily influenced by human labor, and that managerial practices permit food production to occur at levels far exceeding natural productivity. Aquaculture, however, still lacked individual formal statutory recognition (Newton, 1978).

Under the $95^{\text {th }}$ Congress, lobbying to promote aquaculture legislation began to occur. The National Aquaculture Organic Act of 1978 (the Aquaculture Organic Act") was passed, only to be vetoed by the President Carter. ${ }^{10}$ Despite the failure of the 1978 Act, significant support by both houses of Congress represented an overall opinion that a comprehensive formal acknowledgment was vital to continued industry success. In spite of the lack of total support, Newton's point of view suggested the Aquaculture Organic Act was better suited for the industry than the Agriculture Research Act, for the sole reason that it fostered development through coordination of multiple regulatory agencies that have an interest in the industry. Aquaculture would not see formal acknowledgment for three more years until 1980 (Newton, 1978).

As termed by the federal government under the Code of Federal Regulations (CFR), aquaculture is the legal propagation or rearing of aquatic species, utilizing a controlled or selected environment, including but not limited to, ocean ranching. ${ }^{11}$ Legislation was promulgated and adopted, resulting in the National Aquaculture Policy, Planning, and Development Plan Act of 1980 (-the 1980 Act"). ${ }^{12}$ The 1980 Act was revised under the

\footnotetext{
${ }^{10}$ HR 9370, $95^{\text {th }}$ Cong, $1^{\text {st }}$ Sess. (1977).

${ }^{11} 40$ C.F.R. et seq.

${ }^{12}$ National Aquaculture Policy, Planning, and Development Act, 16 U.S.C. $§ 2801$ et seq. Added by Act of Sept. 26, 1980, P. L. 96-362, 94 Stat. 1198.
} 
National Aquaculture Improvement Act of 1985; however, the legislation is still referred to as the 1980 Act. $^{13}$

Under the Act, Congress has since declared that aquaculture presents a current potential for the reduction in U.S. trade deficits in the areas of fisheries, further augmenting the possible food sources produced by both commercial and recreational fisheries. ${ }^{14}$ Furthermore, aquaculture creates a renewable resource that could increase future sustainability of food sources. Congress has declared aquaculture to be a national interest and policy to encourage development of aquaculture in the United States. ${ }^{15}$ Responsibility for the creation of aquaculture practices lies solely in the private sector. ${ }^{16}$ However, it should be noted that the need for development is inhibited by the lack of scientific research, economic funding, jurisdictional conflicts, the disparity between regulatory agencies and their laws, and lastly, an overall lack of societal awareness and knowledge in general. ${ }^{17}$

Under directive of the NAA of 1980, a National Aquaculture Development Plan (NADP) was to be drafted within 18 months of the formal act's establishment. ${ }^{18}$ However, it took until September of 1983 for the NADP to be published (The Joint Subcommittee on Aquaculture of the Federal Coordinating Council on Science, 1983).

\footnotetext{
${ }^{13}$ National Aquaculture Improvement Act of 1985, 16 U.S.C §1732(1), Added by P. L. 99-198, 99 Stat. 1641,

${ }^{14}$ Id. at $\$ 2801$ (a) (1-4) \& (c) et seq.

${ }^{15} \mathrm{Id}$. at $\S 2801$ (c) (1).

${ }^{16}$ Id. at $\S 2801$ (a) (6).

${ }^{17}$ Id. at $\S 2801$ (a) (7).

${ }^{18} \mathrm{Id}$. at $\S 2803(\mathrm{a})(1-2)$ et seq.
} 
The NADP contained six main research areas:

1.) Chapter 1: Summary \& Status of Aquaculture,

2.) Chapter 2: Current Aquaculture Technologies,

3.) Chapter 3: Impediments to Aquaculture Development,

4.) Chapter 4: Existing Programs,

5.) Chapter 5: Recommendations,

6.) Chapter 6: Anticipated Impacts.

The NADP's applicability to this current research can be linked to Chapters 3 and 6 of the report. Chapter 3 specifically outlines general constraints to aquaculture development as follows:
a.) Inadequate assessment of current issues,
b.) Lack of knowledge, economic, and legal barriers,
c.) Inadequate pilot-scale testing and demonstration facilities,
d.) Legal constraints and high start-up costs,
e.) Inadequate transfers of information and technical assistance,
f.) Multiple-use conflicts,
g.) Marketing,
h.) Jurisdictional overlapping and inadequate coordination,
i.) Shortage of trained industry workers.

Specifically, the NADP referenced how few laws or regulations were designed to protect or promote the U.S. aquaculture industry. During that time, most of the regulation existed as a means of environmental or land-use (zoning-based) restrictions that normally hindered development by removing economic incentives needed for the initial start-up. Similarly, the industry was plagued by a particularly lengthy and convoluted permit process, which delayed development by adding time and cost to each individual operation (The Joint Subcommittee on Aquaculture of the Federal Coordinating Council on Science, 1983).

Likewise, the NADP also reported on the issue of jurisdictional overlap affecting U.S. aquaculture. According to 1983 research, many federal agencies and numerous state regulatory and local municipalities affected aquaculture in some fashion. Overlapping occurred when state regulation conflicted with federal oversight, which created a highly convoluted compliance 
structure. This issue surfaced when individual states worked independently of each other, often skewing developmental capacities before federal involvement even was considered an issue.

In Chapter 6 of the report, projections for impacts resulting from the legislation were described. One of the report's primary impacts related policy implementation to shifting market structures. The report acknowledges both the lack of available information and research. The report's projection purports that the addition of legislation provides access to development, which in return supports higher production, at a lower cost per unit. The public benefits from increased production, in line with the language of the 1980 Act, which calls for the development of aquaculture to be in the public's interest (The Joint Subcommittee on Aquaculture of the Federal Coordinating Council on Science, 1983).

The NADP further notes -secondary impacts" which account for environmental considerations. The report acknowledged aquaculture impacts to include:

1.) Changes in Land-Use,

2.) Changes in Water Use,

3.) Effluent Discharge,

4.) Wildlife Biodiversity,

5.) Disease \& Pathogen Introduction,

6.) Recreational \& Sport Fishing.

\section{DEVELOPMENTAL CONSTRAINTS}

This thesis research serves to continue prior, more limited research conducted in 1980, which followed the federal statutory recognition of aquaculture in the U. S. The genesis for research pertaining to legislative development began with the Aspen Systems Report, published in 1981 (Aspen Research and Information Center (Aspen Systems Corporation), 1981). Aspen was hired to conduct research for the Joint Subcommittee on Aquaculture (JSA) as part of an effort to reduce developmental constraints for the nation's industry found by the 1983 NADP report. The Aspen Systems Report, as a limited research manuscript, can be summarized into 
two integral parts. First, the researchers conducted a regulatory constraints review, where a select number of states were evaluated. The second part of their research compiled a regulatory constraints action plan, which was designed to mitigate development hindrance (Aspen Research and Information Center (Aspen Systems Corporation), 1981).

In part one of the Aspen report, under section 1.1, regulatory constraints hindering development were outlined. Aspen's review describes the following constraints: fisheries management, water use, land use, pollution management, health and safety, access to financial capital, labor and transportation, and intergovernmental/international factors. The report notes that gaps, inconsistencies, and duplication often create a burden to development. The report justifies its research by suggesting that legal constraints present the most significant obstacles to growth (Aspen Research and Information Center (Aspen Systems Corporation), 1981).

In the early 1980 's, 32 states were determined to have regulatory frameworks supporting aquaculture in the U.S. Of those 32 states, 8 were selected for the Aspen report on the basis of geography and species. By selecting states based on these criteria, Aspen asserted that the states reviewed constituted a valid representation of the industry in total. This is significant because, as the report's review describes, most aquaculture law and regulation occurs at the state level. But, following the promulgation of the 1980 Act, significant regulatory overlapping began to occur. Beyond the federal and state overlap, there also was inconsistency on a state by state basis, which further complicated the regulatory complexity (Aspen Research and Information Center (Aspen Systems Corporation), 1981).

At the time of publication of the report, many of the states that were chosen had mature industries" for that time period. It was not that these states were necessarily heavily regulated, but that they had an already established aquaculture industry in place, particularly Hawaii, 
Mississippi, and Florida. These states are still major industry producers. This indicates a major limitation of this study, namely that the chosen states did not represent the national trend. This point is reinforced because marine aquaculture in the major producing states is a poor indicator of fresh water production, and vice versa. A marine program may not hold lessons for development in a state where only fresh water production can occur. While there were fresh water states evaluated, even today the chosen states still have very limited total production. Additionally, the states considered to be the top producers" and evaluated at this time were heavily motivated to develop aquaculture because they had limited choices for economic development, such as the State of Hawaii. Agriculture has been found to be an economically feasible option to produce food in Hawaii, in view of its geographic limitations and natural resources. The state had no other choice but to develop industries which could allow them to be somewhat self-reliant from total costly importation (Aspen Research and Information Center (Aspen Systems Corporation), 1981).

One advantage gained by review of the Aspen report was the insight into personal interviews, which were conducted by the research group. Their individual interviews were broken down into a 5-element structure.

1. Overview of operation?

2. What were the perceived regulatory restrictions?

3. Apparent financial impacts?

4. Economic factors?

5. Additional Comments?

Part 2 of the report compiled a plan for solving regulatory constraints. The report notes an analysis completed by Holmstrom (1980) providing recommendations for regulatory inefficiency 
reduction. ${ }^{19}$ Holmstrom's research suggests six main areas that plague aquaculture development and are elaborated as follows:

1. Poor communication

2. Delay

3. Lack of coordination

4. Procedural redundancy

5. Lack of criteria for decision making, as it pertains to regulation

6. State nonconformity of regulatory protocol

Applying Holmstrom's research, Aspen recommended these constraint areas to JSA for federal implementation of regulatory programs (Aspen Research and Information Center (Aspen Systems Corporation), 1981).

\section{LEGISLATIVE CASE STUDY APPROACH}

Prior to this thesis, some states attempted to evaluate aquaculture development, specifically by region. Thomas et al. (1990) provided the first compilation of aquaculture legislation for the north central region (Thomas, Sullivan, Vertrees, \& Floyd, 1990). Thomas et al., (1990) acts as a digest for all of the state statutes or laws passed by the state legislatures in that region. While the majority of text contained compiled legislation, the case study noted two specific limitations of the research. First, each state is different in its approach to development. Following this declaration, some states in the region contained laws that are more specific than others or contained more administrative rules. The research also noted that, in most cases, a majority of the law - n the books" were no longer enforced or applicable to current industry operation. The second limitation to the study noted that additional law concerning the business aspect of aquaculture operations had not been evaluated. This bulletin marks the first attempt where states took the initiative to understand what they had available to assist them during their developmental processes (Thomas, Sullivan, Vertrees, \& Floyd, 1990).

\footnotetext{
${ }^{19}$ Holmstrom, Problems of Regulatory Inefficiency \& Issues to be Considered in Reducing Them, Technical Supplement \#15, Department of Planning \& Economic Development, State of Hawaii (Jan 1980).
} 
In 1995, the Maryland Department of Agriculture (MD DOA) published a report on permitting and regulatory impacts for the industry (Maryland Department of Agriculture, 1995). The MD DOA report evaluated the following areas: water use, effluent discharge, production, and marketing. The conclusions from the MD DOA study indicated that an average of 4-10 permits for overall licensure compliance were mandated for state aquaculture industries. The study also noted that Florida, New York and Texas required more than 20 permits or licenses as part of their compliance programs. This suggests that some states over-regulate, which may lead to unnecessary burdens on industry development. While this material is limited only to permit and licensure regulation, it is a clear indication that the U. S. industry faces regulatory development constraints (Maryland Department of Agriculture, 1995).

\section{STATE DEVELOPMENT PLAN REVIEW}

Nelson, DeVoe, and Jensen reviewed the impacts of state aquaculture development plans (Nelson, DeVoe, \& Jensen, 1999). Their work represents a major attempt at reviewing state developmental progress by looking at the initial legislation and the resulting plan for further industry development. It provided a timeline for a majority of the states who had development plans promulgated. It briefly described the contents of their development legislation and emphasized the significance of plan development following the formal statutory acknowledgement of state industries. The study's findings support the idea that a significant investment must occur to review all potential development approaches before initiating a set plan. The article's discussion supports the idea that sufficient developmental review protects a state from -putting the cart before the horse," in an attempt to minimize developmental errors. This research investment, while initially time consuming and costly, will reduce costs to revise or re-implement later down the road (Nelson, DeVoe, \& Jensen, 1999). 


\section{REGULATORY RANKING APPROACH}

The publication of Wirth and Luzar in 2000 marks the first attempt to rank state regulatory schemes, according to individualized structures, greatly influenced by the political and agricultural-based infrastructure normally associated with aquaculture (Wirth \& Luzar, 2000). The authors note that individual state development occurs in response to the rapid growth of the industry as a whole. They cite that the regulatory environments, often being diverse and convoluted, represent a negative perception for the industry. They further state that constraints to development often occur between industry, regulatory agencies, and separate interest groups over access to natural resources and potential environmental effects. The authors assert that a particular state's regulatory climate is directly influenced by its institutional structure; more specifically the regulatory authority delegated to oversee the respective state industry. The applicability of this article not only affects state development decisions but also may influence individual producer decision-making (Wirth \& Luzar, 2000).

Duff's, Getchis', and Hoagland's 2003, white paper for the Northeastern Regional Aquaculture Center (NRAC) examined aquaculture policies identifying impediments to development (Duff, Getchis, \& Hoagland, 2003). They conducted a survey of both industry and regulatory officials, which represented a variation of the Aspen (1981) methodology. One point on aquaculture policy that was elaborated here was that some laws were viewed as constraining factors, while others promoted an environmentally friendly arena for aquaculture growth. 
Specifically as to the constraints for growth, the Duff paper notes the following areas as the predominant policies that hinder aquaculture growth in the northeast:

1. Convoluted property rights

2. A poorly defined environmental standard for natural resources

3. Poorly defined agency jurisdiction and responsibility

4. Redundant regulation

5. Inefficient wildlife restrictions for fishery stocks

The authors note in their conclusion that aquaculture appears to be one of the most heavily regulated industries in the U. S. Duff's study serves as an extension of the Wirth and Luzar report in 2000, where the authors created a ranking scale for aquaculture regulation. 


\section{CHAPTER 3}

\section{STATE STATUTORY REVIEW SUMMARY}

\section{PURPOSE OF STUDY}

Chapter 3 contains the most up-to-date record of aquaculture legislation currently affecting aquaculture. This review commences following a 1700 statute non-annotated academic study occurred over six months. Additionally, a review was conducted that examined each individual state's administrative code for any rules or extra regulations not found during the initial legislative study. Telephone conferences with state experts were conducted for a majority of the states to gain insight generally not obtained by the initial review. Interesting points-ofview were gained from these interviews.

During the design phase for this case study, we decided to only evaluate the states of the

continental U. S. This study disregards aquaculture production occurring in the U. S. territories because production there normally involves mariculture (marine-focused aquaculture production) requiring legislation not applicable to West Virginia, a land-locked, freshwater production state. We found that Montana, Nevada, New Mexico, New York, North Dakota, Oregon, and Wyoming had minimal or no statutory references for industry review that pertained to this case study. Contacting each state's expert was attempted but unsuccessful.

\section{STATE REVIEW}

\section{Alabama}

Arguments can be made as to when aquaculture in Alabama originated, but it is undisputed that in 1991, the State industry was formally codified under law, with the passage of 
its development plan. Unlike other states, Alabama managed to complete its plan in less than a year (Nelson, DeVoe, \& Jensen, 1999). It can be noted that the State of Alabama in essence developed its legislative procedures along the same time frame as its fellow Southern Regional Aquaculture states. The following states, Arkansas, Georgia, North Carolina, South Carolina, and others, like Alabama, all codified their industry in a similar 4-6 year pattern. Prior to this movement, many of the southern states operated in a de facto $^{20}$ state under the law, rather than $d e$ $j_{u r e}{ }^{21}$. Evidence to support this notion is explained by the existence of the Alabama Catfish Producers, $(\mathrm{Al} \mathrm{CP})$, a division of the Alabama Farmers Federation (ALFA), which is composed of fish farmers across the state involved in aquaculture since 1974 (Walker, 2003-2004).

Deeper research into the Alabama plan explains that the State was vested heavily as its partners included the following members: state officials, both executive and legislative, academia and higher education, industry growers and producers (Nelson, DeVoe, \& Jensen, 1999). The State of Alabama previously had an advisory panel which was tasked with creation of the state plan; however, now it ceases to exist. In the absence of the former advisory panel, the state Department of Agriculture and Industries (AL DOA) has taken control as lead agency working concurrently with both the Department of Environmental Management (ADEM) and the Department of Conservation and Natural Resources (AL DNR) to manage the state industry. ${ }^{22}$ The contents of Alabama's plan included the following: agency jurisdictions, educational research and development possibilities and responsibilities, marketing and promotion, and most importantly strategies for industry development from a legislative point of view.

Interesting facts about Alabama as a producing state have been produced by Matt Walker, the director of ALFA's ALCP, who explains that currently over 25,000 acres of water are

\footnotetext{
${ }^{20}$ De Facto- Actual: existing in fact; having effect even though not formally or legally recognized (Garner, 2009)

${ }^{21}$ De Jure- Existing by right or accordance with law (Garner, 2009).

${ }^{22}$ Ala. Code 1975 §2-3A-2 et seq.
} 
currently used to produce over twenty-five species by two hundred commercial farms (Crew \& Chappell, 2006), (Walker, 2003-2004) In the past decade, even as Alabama lagged behind neighboring Mississippi, the State calculated that it produced over 142 million tons of catfish with a net worth of more than $\$ 98$ million dollars (Crew \& Chappell, 2006). This explains why most of the State's statutes are geared toward expanding and regulating catfish solely under Article II, Marketing of Catfish. ${ }^{23}$ Chapter 11 of the State Code outlines marketing requirements for catfish as well. ${ }^{24}$

While catfish remains Alabama's largest species cultured, the State has established production of other species which include: yellow perch, crayfish, shrimp, tilapia, largemouth bass and bluegill to satisfy recreational and food fish markets. It is estimated that the Alabama aquaculture industry employees over 3,000 workers in various capacities throughout its state industry. Even with the current production estimates, it is stated that Alabama has the natural resource availability (i.e. land/water resources) to continue to support the industry indefinitely, also at an increased rate of ten-times its current production.

Codified provisions in 1994 for licensure of live salt water bait dealers specifically exempted those salt water species which were cultured in an aquaculture environment. ${ }^{25}$ Later in 2000, procedural amendment again revised the statute with regard to transportation of eommercial" saltwater bait designations. ${ }^{26}$

Aquaculture disease control provisions fall within the agricultural livestock legislation. ${ }^{27}$ Also, catfish received its own designation under the code to allow statewide promotion and

\footnotetext{
${ }^{23}$ Id. at $\$ 2-11-30$ et seq.

${ }^{24}$ Id. at $\$ 2-11-33$ et seq.

${ }^{25}$ Id. at $\S 9-12-54-1$.

${ }^{26} \S$ 9-12-54-1, Infra Note 25 at 19.

${ }^{27}$ ALA. ADMIN. CODE §80-3-8 et seq.
} 
regulation. $^{28}$ Interestingly enough, shrimp culture is valued as a marketable product under the agriculture code, eliciting a promotional program mimicking Alabama’s catfish industry. ${ }^{29}$

Research conducted on how Alabama handles federal compliance explains that the State mirrors the USDA requirements for importation/ exportation of fingerlings and aquatic animal health standards through routine sampling and processing. The State of Alabama is unique because channel catfish, a species native to the State, is the most commonly cultured species, which presents no cause to deviate or mandate rules more stringent when dealing with health management.

With regard to aquatic waste management, the State of Alabama does not require NPDES as set forth by EPA due to its adherence to effluent-based limitation guidelines (ELG's), which are monitored on a voluntary basis. Alabama has, however, implemented its own BMP's regarding effluents, holding producers liable to self-reporting which is monitored by ADEM and Auburn University (Boyd, et al., 2003). ADEM holds authority to revert to general NPDES enforcement for any operation that may fall outside of compliance with state regulation regarding discharges from aquaculture.

A phone conversation with Mitt Walker, president of the ALFA Farmers Organization, expressed that state producers were adamant about water quality and ensuring the environment was not only productive for culture but compliant with state regulations. Currently, three private processors are located within Alabama to handle the necessary food processing services in order for products to be accessed to markets for sale. ${ }^{30}$

\footnotetext{
${ }^{28}$ Id. at $§ 80-8-6$ et seq.

${ }^{29}$ Id. at $§ 80-8-10$ et seq.

${ }^{30}$ Telephone Conference, Mitt Walker, September 2010.
} 


\begin{abstract}
Alaska
In 1971, the state legislature of Alaska set forth statutory provisions allowing for equal access" to natural waters of the State. Under these provisions, aquaculture is not exempt from property rights access legislation. ${ }^{31}$ This endorsement provided access for economic growth for the state industry. Similarly, the State recognized early that ownership would be an issue. It addressed this potential concern by expressing under Chapter 4, Article 1, of the Public Lands Code, that aquacultural-based activities (i.e. agriculture) were considered a beneficial use of the state lands, cited as a public interest. ${ }^{32}$ Following the declaration for beneficial aquaculture, in 1978 the State promulgated legislation that promoted private entrepreneurship by classifying private land availability on the condition that the land use was stated in the public's interest". 33 The State codified legislation under the 1983 session which established the potential for development of aquaculture operations in marine sanctuaries, permitted and regulated under the state park system. ${ }^{34}$

Under Chapter 5, Article 1, of the Fish and Game Code, the State outlines duties of the commissioner to regulate and permit aquaculture. ${ }^{35}$ No formal development act exists for the state; however, Alaska did promulgate the Aquatic Farm Act in 1988 under the Fish and Game Code ${ }^{36}$ which authorizes the commissioner to issue permits for the construction and operation of aquatic farms and hatcheries (Alaska Department of Fish and Game (AK DFG), 2011). The State is attempting to codify a permit system that would cover all aspects of compliance both at the federal and state level. Currently, the State does not apply a NPDES program for the simple fact

\footnotetext{
${ }^{31}$ AK Const. Art. 8, §15.

${ }^{32}$ AS $\S 38.04 .015(1)$.

${ }^{33}$ Id. at $\$ 38.04 .035(1)(e)$.

${ }^{34}$ Id. at $\S 41.21 .302(e)$.

${ }^{35}$ Id. at $\$ 16.05 .050(a)(1-16)$.

${ }^{36}$ 5AS 41. (200-400) (Aquatic Farm Regs).
} 
that most production is too small to require producers to apply for a permit. Most finfish production occurs as a means of ocean ranching, which extends out to the federal Exclusive Economic Zone (EEZ), approximately three miles from shore. ${ }^{37}$

\section{Arizona}

In 1989, the State of Arizona began its developmental process by organizing developmental authority under $\S 3-102$ of Title Three of the Agriculture Statute. ${ }^{38}$ During this process, aquaculture originally was grouped with other sectors of livestock under Chapter 11 of the Agriculture Statutes. ${ }^{39}$ Effective January of 1991, Chapter 16 formally designated aquaculture under its own set of statutory provisions. ${ }^{40}$ Under this new statutory reference, the Arizona Department of Agriculture (AZ DOA) assumed responsibility as lead agency for aquaculture under its animal services division ${ }^{41}$.

The importance of this is that Arizona has its own supervisor of aquaculture, who serves under the AZ DOA. This supervisor is tasked specifically with handling all aquaculture-related inquiries and issues. ${ }^{42}$ Agency cooperation is also outlined under the 1990 revision to Chapter 16 , where promotion of the interests of aquaculture may include research and dissemination of pertinent information with public and resulting industry. ${ }^{43}$

Separate research into the state administrative code provided additional regulation codified under Title 3 of the State Agriculture Regulation. ${ }^{44}$

\footnotetext{
${ }^{37}$ Telephone Conference Cynthia Pring-Ham, August 2010.

${ }^{38}$ A.R.S. § 3-102.

${ }^{39}$ Id. at § 3-1201.

${ }^{40}$ AZ ST T. 3, Ch. 16, Refs.

${ }^{41}$ Id. at $\S 3-2901(6)$ (7).

42 Id. at $\S 3-2902$, et seq.

${ }^{43}$ Id. at $\S 3-2903(4)(5)$.

${ }^{44}$ ARIZ ADMIN. CODE Title 3 Agriculture, Article 10: Aquaculture Regulation.
} 
General licensure is pursuant to R3-2-1003 of the State administrative rules and regulations. ${ }^{45}$ Article 10 also requires aquaculture facilities in the State to apply and hold a facility-wide license. ${ }^{46}$ The transportation of aquatic wildlife is managed under the Title 17 of the Game and Fish Code. ${ }^{47}$ Similar regulation can be referenced under Title 3 of the administrative code. ${ }^{48}$ Under statute, if an aquaculture facility is found compliant with requirements set forth under Chapter 16 of the Aquaculture Code, then an exemption will be given for the processing or storage of animals cultivated under such facility. Processors in Arizona are also required to comply with regulation under Article 10 mandating operating licensure. $^{49}$

Public outreach for information in Arizona is on the rise. Pursuant to statute, the State has promulgated regulation authorizing special use licenses for educational purposes which are not renewable, only valid in 3 year durations. ${ }^{50}$ The University of Arizona has implemented a user-friendly website comprising links to newsletters, research and extension activities, and state aquaculture associations (The University of Arizona, 2011). While the latest updated Arid Lands newsletter available to the public is dated from 2002, it is interesting to research that in 2001, approximately 1,646,000 lbs. of product was processed. The market value for this production was released at $\$ 3.7$ million dollars for 2000 and 2001 (University of Arizona College of Agriculture, Department of Soil, Water, and Environmental Sciences, 2002). But the most impressive area Arizona established is the outreach programs, found by accessing its aquaculture website, which were implemented at the high school level for tilapia, trout, and catfish.

\footnotetext{
${ }^{45}$ Id. at R3-2-1003.

${ }^{46}$ Id. at R3-2-1004.

${ }^{47}$ A.R.S. $\$ 17-273$ (A)(B).

${ }^{48}$ ARIZ ADMIN.CODE R3-2-1007.

${ }^{49}$ Id. at R3-2-1006.

${ }^{50}$ A.R.S. §3-2908(A).
} 
Chapter 16 further outlines procedures for compliance with licensing at the state level to include any aquaculture facility or activity. ${ }^{51}$ Under Chapter 16, Arizona designates a quality and disease control mandate for regular monitoring and diagnostic procedures and sets forth guidelines for quarantine and destruction of aquatic animals and plants. ${ }^{52}$ Mandatory inspections and certifications are required for all aquaculture based facilities. ${ }^{53}$ Under the administrative code, the state industry is required to comply with disease certification requirements. ${ }^{54}$ Aquaculture enterprises must review the importation requirement referenced under R3-2-1010. ${ }^{55}$

The State has reserved the authority to place restriction on water supply or tailing water discharges to aquaculture based facilities if the discharges are deemed detrimental to aquatic wildlife. ${ }^{56}$ Permits are required to protect aquifers under Chapter Two, Article $3 .{ }^{57}$ With regard to discharge compliance, Arizona follows a BMP plan for aquaculture effluents. However, a state driven pollutant discharge program does exist under Title 18 of the state administrative code $^{58}$ The state Department of Environmental Quality (AZ DEQ) has primary authority to ensure nitrogen-based wastes, discharging from aquaculture facilities, do not pollute waters of the state. Aquaculture facilities may be required to obtain NPDES permits from AZ DEQ, which are evaluated on an individual application basis. ${ }^{59}$ It is recommended that contact be made with AZ DEQ to determine specific permit requirements (Fitzsimmons, 1998). This contact is necessary to ensure application for the right permit based on an individual operation. The State

\footnotetext{
${ }^{51}$ A.R.S. § 3-2907, et seq.

52 Id. at § 3-2904.

53 Id. at § 3-2905.

${ }^{54}$ ARIZ ADMIN.CODE R3-2-1009.

55 Id. at R3-2-1010.

${ }^{56}$ A.R.S. $§ 3-2909$.

${ }^{57}$ Id. at $\S 49-248(A)$.

${ }^{58}$ ARIZ ADMIN.CODE Title 18 Environmental Quality, Article 9: Pollutant Discharge Elimination System Program.

${ }^{59}$ Id. at R18-9-B901-B907 et seq. (Part B. Individual Permit Requirements).
} 
also has a general discharge permit referenced also under Title $18 .^{60}$ Biosolid waste regulation may apply to aquaculture, which can be referenced under Article 10 of Title 18 of the state administrative code. ${ }^{61}$

\section{Arkansas}

Traditionally viewed as the leading rice producing state with regards to U.S. agriculture, Arkansas is also ranked second in the U.S. for its aquaculture production, according to data reported by the University of Arkansas's Division of Agriculture. Aquaculture Cooperative Extension Service programming in Arkansas is administered through the Aquaculture/Fisheries Center at the University of Arkansas, Pine Bluff (UAPB). Currently in Arkansas, five extension fisheries specialists and an extension technician provide assistance to the aquaculture industry from locations including: Lonoke, Pine Bluff, and Lake Village, Arkansas (University of Arkansas, Division of Agriculture, Research, \& Extension, 2011).

Arkansas operates its industry much differently than other states. For instance, Arkansas lacks a formal aquaculture act, but does have statutes in place that formally recognizes catfish, as referenced by Chapter 61 Fish and Seafood code of $1975 .^{62}$ Aquaculture is formally designated as agriculture under general provisions of the 1981 Agricultural Code in Arkansas. ${ }^{63}$ An ancillary committee was promulgated under Act 1760 in July of $2003 .^{64}$ The purpose of this committee was to promote agriculture sectored businesses, specifically including aquaculture. ${ }^{65}$ In 2005 , aquaculture in the State is represented by the state Department of Agriculture (AR DOA). ${ }^{66}$

\footnotetext{
${ }^{60}$ ARIZ ADMIN. CODE Title 18 Environmental Quality, Article 9, Part C. (General Permits).

${ }^{61}$ Id. at R18-9-1003-1015 et seq. (Article 10: Disposal, Use, \& Transportation of Biosolids).

${ }^{62}$ A.C.A. $\$ 20-61-206(a)(1-4)$

${ }^{63}$ Id. at § 2-4-102(2).

${ }^{64} \mathrm{Id}$. at $§ 2-1-206(\mathrm{~b})(4)$.

$\$ 2-1-206$ et seq., Infra Note 64 at 25.

${ }^{66}$ Id. at $\S 25-38-203(3)(4)(6)(7)$
} 
The State has vested interest in the development of aquaculture-based enterprises when it endorsed the activity under the 2007 Research Parks Authorities Act. ${ }^{67}$ Access to finance has been stated to be a constraint to aquaculture development. Therefore, in 1987, the state attempted to avoid this concern by codifying legislation that recognizes and allows aquaculture access to capital investments, under Title 15 of the Natural Resources and Economic Development Code $^{68}$ Under a recent amendment, a transfer occurred where aquaculture operations under the state Development Finance Authority were now regulated under the AR DOA. ${ }^{69}$ Now under new direction, aquaculture is overseen by the state agriculture board which acts in summary as an advisory board appointed by the governor. ${ }^{70}$

While the State lacks major aquacultural focused legislation, the state Game \& Fish Commission (ARGFC) has implemented regulation which can be referenced in the state code of regulations (Arkansas Game and Fish Commission, 2000-2001). Section 42.00 pertains to fish farming regulation. The ARGFC has implemented permit requirements. ${ }^{71}$ Record keeping is vital to efficient management of much of the state industry and subsequent regulation was passed to mandate it as a requirement for compliance. ${ }^{72}$ Transportation and sale compliance for white crappie production is also referenced under the state code of regulation. ${ }^{73}$ Rearing regulation of aquatic wildlife is referenced under Section 42.00 as well. ${ }^{74}$ Paddlefish and sturgeon culture is

\footnotetext{
${ }^{67}$ Id. at §14-144-204( b)(2)(c).

${ }^{68} \mathrm{Id}$ at $\$ 15-5-103(2)$.

${ }^{69}$ Id. at $\S 25-38-204(5)$.

${ }^{70}$ Id. at $\S 25-38-207$ (b).

${ }^{71}$ Section 42.02 (Fish Farmer Regulation).

${ }^{72}$ Id. at $\$ 42.02$.

${ }^{73}$ Id. at $\$ 42.05$

${ }^{74}$ Id. at $\S 42.06$.
} 
protected in Arkansas. ${ }^{75}$ Lastly, biosecurity regulation pertaining to importation is referenced under Section 42.11. ${ }^{76}$

Overall, aquaculture in Arkansas has been occurring since at least early 1960 with the introduction and production of grass carp. While Arkansas lacks major aquacultural focused legislation, the state industry has managed to thrive on the voluntary participation of its producers. The State follows many of the EPA's requirements for effluent-based limitations and guidelines for discharge since much of the production are static, occurring in ponds rather than traditional flow-through systems. Similarly, animal health certification occurs on a voluntary basis, since much production is export-based to meet demand for stock overseas and also in nearby states. Interstate transportation and importation regulation requires certification before export. This information was gained during a recent telephone conference with a state aquaculture contact from the University of Arkansas, location, Pine Bluff. ${ }^{77}$

\section{California}

Beginning in 1982, the State of California codified legislation under Division Five of the Fish and Game Code, which recognized aquaculture as a viable industry. ${ }^{78}$ Pursuant to Division Five was regulation mandating a classification of both wild animals v. domesticated animals" under Chapter 2, Division 3 of the state Fish and Game Code. ${ }^{79}$ This regulation was pertinent for two reasons; first, to alleviate species ownership, and second, to stimulate industry growth. Later, in 1998, law was promulgated to consolidate all aquaculture law under one section of code, as it pertains to fish and game, with the sole intention of alleviating impairments to

\footnotetext{
${ }^{75} \mathrm{Id}$. at $\S 42.10$.

${ }^{76}$ Id. at $§ 42.11$

${ }^{77}$ Telephone Conference, Nathan Stone, June 2011.

${ }^{78}$ Ca. Fish \& Game Code, D.05, Aquaculture.

${ }^{79}$ Cal. Fish \& G. Code $\$ 2116$ (Definition).
} 
development. ${ }^{80}$ Following 1995, Chapter 7, under Division 2 of the Fish and Game Code, declares aquaculture to be beneficial to the public subject to public policy. ${ }^{81}$ Aquaculture provisions were grouped with commercial fishing statutes under Division 12. The State addressed the ownership of wild animals under $\S 15001$; this is always a continuing battle for aquaculture development because of the nature of ownership of products while in captivity versus their status upon release. ${ }^{82}$ After the 1998 revision, Chapter 2 sets forth the Aquaculture Development Section, specifically addressing employment of an aquaculture coordinator, facility licensure and registration, and fees and penalties. ${ }^{83}$ Chapter 2 also sets forth the state aquaculture coordinator position under statute. ${ }^{84}$

Specific aquaculture regulation that differs from statutory law can be referenced by reviewing the state code of regulation. ${ }^{85}$ Under this regulation, the sale of live aquaculture products is outlined. ${ }^{86}$ Aquaculture enterprise registration is mandated under the same code. ${ }^{87}$ Any operation looking to sell or transport products must comply with the regulation for all aquaculture products cultured in the state. ${ }^{88}$

Aquatic animal health standards are set forth in Chapter 6 called disease control. ${ }^{89}$ This portion of the statute calls for the appointment of an eleven member committee, that reports directly to the state Aquaculture Industry Advisory Committee, whose overall purpose is to research and recommend regulations designed to safeguard both wild and cultured products. ${ }^{90}$

\footnotetext{
${ }^{80}$ CA. Fish \& Game Code, D. 12, Aquaculture.

${ }^{81} \mathrm{Id}$. at $\S 1700(\mathrm{f})$.

82 Id. at $\S 15001$.

${ }^{83}$ Id. at $\S 15101-05$.

${ }^{84}$ Id. at $\$ 15100$ et seq.

${ }^{85} 14$ CCR, Aquaculture Regulation

${ }^{86} \mathrm{Id}$. at $\$ 227$ et seq.

${ }^{87}$ Id. at $\$ 235$ et seq.

${ }^{88} \mathrm{Id}$. at $\$ 238-239$ et seq.

${ }^{89}$ Cal. Fish \& G. Code § 15500-16.

${ }^{90}$ Id. at §15502-03.
} 
Under Title 13 of the State Code, requiring warrants for inspection, aquaculture is referenced as a viable industry covered under state statute..$^{91}$ The importation of mollusks and aquatic plants is regulated by the state Department of Natural Resources. ${ }^{92}$ Also, California imports anadromous species, which require regulation that can be reviewed under the state code of regulations. ${ }^{93}$

Shellfish culture is mandated by statute to comply with the state health and safety code as it pertains to the wholesale of cultured products. ${ }^{94}$ By law, the state health board may conduct routine seafood sample testing to ensure the safety of products being introduced into the marketplace. ${ }^{95}$

Similarly, under Chapter 4, the Department of Fish and Game is mandated to inspect for injected, diseased, or parasitized products for the protection of humans and environment alike. ${ }^{96}$ Importation requirements for aquatic plants and animals under state regulations are detailed in Chapter 7. ${ }^{97}$ Section 2270.5 under Article 3, Chapter 3, discusses importation requirements of aquatic species from diseased areas, while providing an exemption if the importation practice has been preapproved by the Department of Fish and Game pursuant to Section $15600 .^{98}$ The State has enacted regulation for aquaculture disease control specifically, which can be referenced online under the administrative code as well..$^{99}$

Chapter 5 of Division 12 outlines state property leasing for purposes of aquaculture development. ${ }^{100}$ Similarly, regulation pertaining to the state leasing program for state water

\footnotetext{
${ }^{91}$ CA. C.C.P. Pt. 3, T. 13.

9214 CCR $§ 236$ et seq.

${ }^{93}$ Id. at $\$ 236.1$ et seq.

${ }^{94}$ Cal. Health \& Safety Code $\$ 112165(1)$.

${ }^{95}$ Id. at $\$ 114775$ et seq.

${ }^{96}$ Cal. Fish \& G. Code $\S 6301$. Stats.2007, c. 285 (A.B. 1729), §108.

${ }^{97}$ CA. Fish \& Game Code, D. 12, Aquaculture $\S 15600-05$.

${ }^{98}$ Id. at $\$ 2270.5$ (w/ exemption provision).

${ }^{99} 14$ CCR $§ 245$ et seq.

${ }^{100}$ Cal. Fish \& G. Code $\S 15400$, et seq.
} 
bottoms can be referenced under the administrative code. ${ }^{101}$ Much like Alaska, the State of California has a public access leasing program for the economic development usage of the state water bottoms. ${ }^{102}$ Regulated by the CADFG, this leasing program is permitted on a conditional basis that maintains any recreational pursuit must not degrade the resource in any aquaculture culture area. This investment is viewed as a means of public policy pursuant to Section $1700 .{ }^{103}$ The State, valuing the potential diminishment of its domestic water sources, enacted regulation that mandates a water quality control plan. ${ }^{104}$ Under Chapter 3, Article 3, the State has a purchasing program to stimulate private operations for its urban fishing program under a conditional agreement. This agreement becomes null and void if the private facilities are unable to provide specific species for program participation; or if the species are found to be infected or diseased. ${ }^{105}$ The urban fishing program can be referenced as part of the California Aquaculture Promotion Act of $1995 .^{106}$

Similarly, under the Section 2 of the 1995 act, the legislature acknowledged that the commercial aquaculture industry within the state had been significantly stifled due to duplicate and costly regulation and illegal importation and trading in aquaculture products." ${ }^{" 107}$ Marketing responsibilities for the state aquaculture industry were transferred under the 1995 act from the state Fish and Game to the state Food and Agriculture Service. ${ }^{108}$ Prior to the 1995 act, an Interagency Committee for Aquaculture Development existed but was abolished by the promulgation of the act to later become the state development committee. This newly created

\footnotetext{
10114 CCR $\$ 237$ et seq.

102 Cal. Fish \& G. Code $\S 15400$.

${ }^{103}$ Id. at $\$ 15411$.

10423 CCR $\S 667$ \& 3920 et seq.

105 Id. at $§ 1123.5$

${ }^{106}$ Sections 1 and 2 of Stats.1995, c. 810 (A.B.1636)

107 Section 2, Infra note 274 at 27.

${ }^{108}$ CA LEGIS 810 (1995)(1).
} 
development committee was mandated to report to the Department of Fish and Game, with recommendations on improvements to effectively stimulate the state industry. ${ }^{109}$ For all intents and purposes, the 1995 Act should be considered the precursor to the state aquaculture development act under Chapter 4 in 2001. ${ }^{110}$

Chapter 8 sets forth the state's Aquaculture Development Committee, containing at least 12 members representing both fresh and marine sectors of the industry. ${ }^{111}$ Chapter 9 originally discussed the interagency committee, developed for coordination with the advisory committee and disease council, but now ceases to exist after legislation passed in 1995 repealed this section. ${ }^{12}$ Chapter 1 under the Fish and Game Code redefines marine finfish aquaculture, which was the result of industry lobby back in $2006 .^{113}$ Furthermore, ocean ranching practices were defined under Section 61 of Chapter $1 .^{114}$ Under Chapter 4, the lead agency is described to be the state Department of Fish and Game (CA DFG).

Similarly, the state legislature had also originally organized provisions for ocean ranching practices under Chapter 10, which also were later repealed under SB $1176 .{ }^{115}$ During the same time period when marine ocean ranching was a priority; the state legislature codified the Marine Life Protection Act, which included provisions that required submitting master plans with the Joint Committee on Fisheries and Aquaculture. ${ }^{116}$ In essence, the submission for a master plan acted as a federal NEPA review for any potential harmful activity degrading the natural

\footnotetext{
${ }^{109}$ CA LEGIS, Infra note 276 at 27.

${ }^{110}$ Cal.Pub. Res.Code D.1, Ch.4 Aquaculture Development Act.

${ }^{111}$ CA. Fish \& Game Code, D. 12, Aquaculture $\S 15700-03$.

112 Id. at $\S 15800-03$, repealed by Stat. 1995, c. 810 (A.B. $1636 \S 10$ ).

${ }^{113}$ Cal. Fish \& G. Code $§ 54.5$.

${ }^{114}$ Id. at $\$ 61$.

${ }^{115}$ Id. at $\S 15900-08$, repealed by Stat. 1995, c. 677 (S.B. 1176 §6).

${ }^{116}$ Id. at $\S 2859(d)$.
} 
environment. ${ }^{117}$ An interesting side note, following the Exxon Valdez spill in 1991, the State codified oil spill prevention measures to protect marine finfish cultured by ocean ranching. ${ }^{118}$

Chapter 5, Article 8 outlines the state drive ocean resource enhancement program, which is a research driven initiative, aimed at maintaining ocean fisheries, etc. ${ }^{119}$ Moreover, under this program, a 10 member panel is created which oversees research and development on ocean fisheries, not to exclude marine ocean ranching. ${ }^{120}$ The State in 1998 acknowledged the importance of balancing commercial aquaculture growth with fisheries management. ${ }^{121}$

A telephone conference with the NASAC coordinator described approximately 200 producers that comprise the state industry, where freshwater culture dominants due to regulatory impairment in the marine production sector. ${ }^{122}$ NPDES requirements are to be met according to CWA mandates under state code Chapter 5.5, Division Seven. ${ }^{123}$

\section{Colorado}

Taken from legislation passed in 1975 under Article 1 of the state Administrative Organizations Act of 1968, aquaculture was to be created and regulated by the Colorado Department of Agriculture (CO DOA). ${ }^{124}$ Under this act, an oversight board was to be created and its duties of creating the state industry were to be transferred to the CO DOA by a Type-Two transfer pursuant to Title 35 C.R.S. ${ }^{125}$ Subsequently, the State codified its aquaculture development act (CO ADA) in 1991 under Article 24.5 of the Agriculture Code referenced under

\footnotetext{
${ }^{117}$ Stats. 1999, c. 1015(A.B. 993), §1, later amended by Stat. 2001, c. 753 (A.B. 1673), §3; Stats.2002, c. 559(A.B.892), §2.

${ }^{118}$ Cal. Fish \& G. Code $\$ 5654(a)(1), \&(f)(2)$.

${ }^{119}$ Id. at $\S 6954$ et seq.

${ }^{120} \S 6954$, Infra Note 119 at 32.

${ }^{121}$ Cal. Fish \& G. Code $\$ 7050(4)(7)$.

${ }^{122}$ Telephone Conference, Heather McIntire, July, 2010.

${ }^{123}$ Cal. Water Code $§ 13382.5$

${ }^{124}$ C.R.S.A. $\S 24-1-123$ et seq.

${ }^{125}$ Id. at $\S 24-1-123(i)(6)$.
} 
Title $35 .{ }^{126}$ Under Section 102, the CO ADA was to be considered an agricultural enterprise, as defined by the Colorado Agricultural Development Act of 1981, which was the precursor to the CO ADA. ${ }^{127}$ Under the 1981 Act, aquaculture is recognized as a viable agricultural enterprise. ${ }^{128}$ The CO ADA contains language which creates an aquaculture board within the CO DOA, consisting of seven members. ${ }^{129}$ Regulation and rules are the main duties of the board, as outlined under Section 107. ${ }^{130}$ Administrative code sets forth the enforcement of the state development act under law. ${ }^{131}$

Facility permitting is outlined under the COADA, mandating a valid application for any facility for the purposes of propagating, selling, trading, or transporting live fish or viable gametes. ${ }^{132}$ Under Section 109(5), an exception to the permit requirement is declared for facilities not connected to state waters, which protects native biodiversity and pathogen introduction. ${ }^{133}$ Likewise, under statute, individuals holding a permit pursuant to Section 109 may charge a fee for sport fishing at such permitted facility, but no formal state fishing license is required. ${ }^{134}$ Moreover to alleviate unnecessary permits, the State has approved the creation of a plant wide permit for aquaculture enterprises which operate with several satellite stations. ${ }^{135}$

In an attempt to address any potential fish health concerns, the State in 1991 implemented a fish health board, which can be referenced under the Wildlife and Parks and Outdoor Recreations Code, Title 33, Article 5.5. ${ }^{136}$ The state fish health board has been tasked with

\footnotetext{
${ }^{126}$ CO ST $\S 35-24.5-100$ et seq.

${ }^{127}$ Id. at $\S 35-24.5-102(2)$.

${ }^{128}$ Id. at $\S 35-73-103(1)$.

${ }^{129}$ Id. at $\S 35-24.5-104(1)(a)$.

${ }^{130}$ Id. at $\S 35-24.5-107(1)$ (c)\&(3).

${ }^{131} 8$ CCR $1201-1221$ et seq. Administrative Enforcement of CO ADA.

${ }^{132}$ CO ST §35-24.5-109(1).

${ }^{133}$ Id. at §35-24.5-109(5).

${ }^{134}$ Id. at $\$ 33-4-102$ (12)(a)

${ }^{135}$ Id. at $\S 33-4-102(12)(b)$.

${ }^{136}$ Id. at §33-5.5-101(c).
} 
mitigating the spread of aquatic disease within private aquaculture facilities or cultured aquatic stocks, through adequate regulation of importation into the state and distribution of exotic aquatic species. ${ }^{137}$ The state wildlife commission has enacted regulation pursuant to chapter 0 , Article VII, which outlines aquatic wildlife health management provisions. ${ }^{138}$ Similarly, under the same article of wildlife regulation, importation of aquaculture production must be reviewed to ensure compliance. ${ }^{139}$ Likewise, any form of transportation will trigger regulation pursuant to Article VII. $^{140}$

During a recent telephone conversation with the state NASAC contact, it was discovered that approximately 47 licensed aquaculture operations currently exist in the state. Of those licensed operations, the following species are cultured: trout, bass, bluegill, catfish, carp, walleye. Baitfish are generally imported from other states and tested for pathogens prior to introduction. $^{141}$

\section{Connecticut}

Under statute, the State of Connecticut determined that aquaculture is to be defined as agriculture". ${ }^{142}$ The state has declared state policy to develop aquaculture under Chapter 438, Title 22. ${ }^{143}$ The state Department of Agriculture (CT DOA) has assumed the role as lead agency under statute. ${ }^{144}$ Created in 1994, an Interagency Aquaculture Coordinating Committee was initiated with the intention of developing and enhancing aquaculture in the State. ${ }^{145}$ The coordinating committee was comprised of members representing the CT DOA, the state

\footnotetext{
${ }^{137}$ Id. at $\S 33-5.5-102(1) \&(6) \&(8)$.

${ }^{138}$ COLO. CODE REGS. Ch.0, Art. VII, \#014 et seq. (Aquatic Health Management). Colorado Wildlife Commission Regs.

${ }^{139}$ Id. at \#011.

140 Id. at \#010.

${ }^{141}$ Telephone Conversation, Scott Leach, May 2011.

${ }^{142}$ C.G.S.A. $§ 22-11(c)$.

$143 \mathrm{Id}$. at §22-416 et seq.

${ }^{144}$ Id. at §22-11d.

${ }^{145} \mathrm{Id}$. at §22-11e et seq.
} 
Department of Environmental Protection (CT DEP), and the state Department of Economic and Community Development (CT DED). ${ }^{146}$ Based on Section 22-11e (b), the committee was instructed to develop a strategic plan by 1995. Also, the State promulgated a state aquaculture commission to act as the advisory body for industry oversight under Chapter $438 .{ }^{147}$ Recent statutory amendment has, however, repealed the existence of the aquaculture commission. ${ }^{148}$ In 1998, the State codified its development plan under statute. ${ }^{149}$

The CT DOA, working in conjunction with the CT DEP, has been tasked together to adopt regulation to implement a licensing program for aquaculture facilities to control importation, cultivation, or the raising of aquatic plants and animals, which are non-native to the state. ${ }^{150}$ This legislation acts to protect the environment from the impact of contamination of wild stocks of aquatic plants or animals through invasive introduction. Generally, licenses and permits regarding transportation and exportation of aquaculture products must be obtained. ${ }^{151}$ Recent amendment to statute Section 26-57 provides authorized licensed aquaculture facilities an exemption, if the transport of live aquaculture products occurs within state boundaries to hatcheries or other potential stocking areas subject to waters of the State, on the condition that the live products are indigenous. ${ }^{152}$ Exclusive authority to grant or deny aquaculture permits, excluding water discharge concerns, lies with the CT DOA. ${ }^{153}$ Concerns over water issues will be addressed by the CT DEP.

\footnotetext{
${ }^{146} \S 22-11 \mathrm{e}$, Infra Note 145 at 34.

147 Id. at $\$ 22-416(\mathrm{a})(\mathrm{b})$.

${ }^{148}$ Id. at $\S 22-417-22-449$. Repealed. (1997, P.A. 97-234, §11).

${ }^{149} \mathrm{Id}$. at $\S 22-11$ et seq.

${ }^{150}$ Id. at $\$ 22-11 \mathrm{f}$.

${ }^{151}$ Id. at $§ 26-57$ et seq.

152 §26-57, Infra Note 151 at 35.

153 Id. at $§ 22-11 \mathrm{~h}(\mathrm{a})$.
} 
The CT DOA has assumed responsibility to oversee releases from aquaculture operations that incorporate storage from the following: tanks, containers, impoundments, and ponds. ${ }^{154}$ The CT DOA works concurrently with the CT DEP to maintain water quality, but the CT DEP operates and regulates its own set of aquacultural-focused release systems. Water Pollution control measures are outlined under the CT DEP statutes, referenced under Chapter $446 \mathrm{~K} .^{155}$ The CT DEP requires a permit for water discharges, which can be referenced under Section 22a$430(\mathrm{C})$. This permit requirement is subject to review, pending a withdraw notice and comment period. Also, a flow diversion exemption measure has been codified. ${ }^{156}$ Under the direction of the CT DOA, releases from such aquaculture enterprises are subject to notice to the commissioner of the CT DOA under statute. ${ }^{157}$ With regard to the CT DEP, any aquaculture enterprise must apply for a permit for dredging or erection of structures, gravel placement, or fill and mooring areas under legislation passed in 1997 and amended in 1998, which is when aquaculture was affected by this statute. ${ }^{158}$

The State has made an investment to developing its industry through its support on the part of its Regional Agricultural Sciences and Technology Education Centers. ${ }^{159}$ This push to educate both industry and the public serves to benefit the industry, by encouraging the youth to become more involved in a vocation involving either an aquaculture or other marine-related employment position. ${ }^{160}$ Similarly, under the same program, aquaculture grants are available for research and information dissemination to fund courses which endorse the industry. ${ }^{161}$ The

\footnotetext{
154 Id. at $\S 22-11 \mathrm{~g}$.

155 Id. at $\$ 22 a-430$ et seq.

${ }^{156}$ Id. at $\$ 22 a-367$ et seq.

${ }^{157} \S 22 a-367$, Infra Note 16 at 36.

158 Id. at $\$ 22 a-361(e)(3)$.

${ }^{159}$ Id. at $§ 10-64$ et seq.

160 Id. at §10-64(c).

${ }^{161}$ Id. at §10-65(b).
} 
public school system has received legislation that recognizes aquaculture in the classroom under statute. $^{162}$

The State has placed regulation on the sale of turtles cultured in commercial aquaculture facilities, which were not collected from the wild prior. ${ }^{163}$ On the other hand, the State actively promotes the marketing of aquaculture products as farm products," so long as the products are concurrent with Section 1-1 of the state code. ${ }^{164}$ Aquaculture product marketability is dependent on farmer's market certification. ${ }^{165}$ To date, animal health requirements follow state law under interim guidelines for freshwater production mandated by the USDA under APHIS (U.S. Department of Agriculture; Animal and Plant Health Inspection Service (APHIS), 2007).

Recently, the State has mandated that -any" discharge of water, substance, or material into the waters of the State requires a permit issued by the Department of Environmental Protection. The discharge permit is required for Federal Clean Water Act compliance and the protection of the State's water quality and aquatic resources. Following the implementation of state driven NPDES, Connecticut now requires water diversion permits. The withdrawal, alteration, modification or diminution of State water resources for consumptive uses greater than 50,000 gallons per day requires a permit issued by the Department of Environmental Protection. The permit is required to protect the State's water resources (Connecticut Department of Agriculture, N.D.).

A telephone conference with the state NASAC contact returned information which suggests that the industry is heavily climate-affected. The state marine sector is larger than the freshwater production. For the most part, freshwater production occurs in a contained pond

\footnotetext{
${ }^{162}$ Id. at $\S 10-282(15)$.

${ }^{163}$ Id. at §19a- 102(c).

${ }^{164}$ Id. at $\$ 22-6 g(11)$.

${ }^{165} \mathrm{Id}$. at §22-6r(7).
} 
environment, while marine production is also cultured in closed containment systems. The State has a separate Seafood Council, which handles marketing and promotion capacity for much of the shellfish culture. Talk of a proposed tax on aquaculture products may result in upcoming legislative sessions. But at the current time, this is speculative. Due to a non-mandatory reporting requirement to the U.S. Census of Agriculture, the State has not reported production data and values. ${ }^{166}$

\section{Delaware}

In 1990, the State codified legislation now known at the state aquaculture act under Chapter 4 of the Agriculture code. ${ }^{167}$ Under the 1990 act, the state Department of Agriculture (DE DOA) assumed the role as lead agency over aquaculture. ${ }^{168}$ Similarly, the DE DOA has been tasked with the development of a technical assistance and marketing program to assist industry and promote the industry alike. ${ }^{169}$ Also, based on the language of the 1990 Act, a 12 member state aquaculture council is to be created to enhance and promote the industry, acting as a recommendation body to the DE DOA. ${ }^{170}$ Aquaculture is also represented as part of the state Agricultural Lands Preservations Act codified in 1998. ${ }^{171}$

The State is concerned with invasive outbreak of pathogens and a loss of biodiversity; therefore, under statute, the State explicitly describes measures to ensure that these concerns do not come to fruition. ${ }^{172}$ Following with this protection, statutes under the 1990 Act have been promulgated to cover aquaculture facilities. ${ }^{173}$ The state Department of Natural Resources and

\footnotetext{
${ }^{166}$ Telephone Conference, David Carey, September, 2010.

${ }^{167}$ DE ST TI $3 \S 401$ et seq.

${ }^{168}$ Id. at $§ 403(9)$.

${ }^{169}$ Id. at $\$ 404$ et seq.

170 Id. at $\$ 405$ et seq.

${ }^{171} 3$ Del.C. §902(3).

172 Id. at $\$ 407$ et seq.

173 Id. at $\$ 409$ et seq.
} 
Environmental Control (DE DNR) handles permits for finfish culture in tidal waters under Title $7{ }^{174}$ To guard against unlawful propagation of finfish from aquaculture operations, the DE DNR has issued a mandate requiring permits for capture within a certain slot limit to be issued. ${ }^{175} \mathrm{An}$ interesting point regarding aquaculture was found during the research phase where a reciprocity agreement existed between Delaware and New Jersey, which promotes both industry construction and development for public benefit under the Delaware-New Jersey Compact, originally signed into effect back in $1953 .{ }^{176}$ This promotion of commercial focus fisheries suggests the investment Delaware has made to develop aquaculture to culture products.

An outlook publication released through the North Central Regional Aquaculture Center (NRAC) in 2009 discusses the two main constraints to industry development are the following:

1.) Lack of a formal development plan or set of regulations following the development legislation passed in 1990, and

2.) No state policy has been developed for either shellfish or finfish aquaculture production occurring in tidal waters (McIntosh \& Ewart, 2009).

A telephone conference with the state NASAC contact suggests that Delaware currently is the only Northeast state without a commercial shellfish industry. Production is small and occurs as semi-flow through, closed-recirculation systems. Delaware growers culture tilapia, baitfish as fingerlings for restocking, however, a disease outbreak has stifled both industries. Most tidal water production lacks a formal water rights structure which has been suggested to be a hindrance to growth inter alia. ${ }^{177}$ Political regime change has had a significant influence on the lack of support and financial backing for the state industry. With a location access to large product markets such as Boston, New York City, and Washington D.C., Delaware should be able to expand with the necessary political backing. The conference suggested that regulation

\footnotetext{
1747 Del.C. $\$ 903(\mathrm{j})$.

${ }^{175}$ Id. at $\S 929(\mathrm{a})$.

17617 Del.C. $\$ 1701$ et seq.

177 "among other things"
} 
promulgated for the industry matches the direction it should reach in the future; it just needs a catalyst to drive growth and development. The Division of Fish and Wildlife (DE DFW) regulates the harvest of finfish and shell fish, stocking, endangered and threatened species, and injurious fish bans. This agency regulates fresh and saltwater species. On a side note concerning aquatic animal health, all certification and registration requirement are to be met with DE DOA. $^{178}$

\section{Florida}

The State of Florida devised an act in 1984, completing its development plan one year later in 1985. The Florida plan can be referenced under Chapter 597 of the Florida Statute. Referencing Chapter 597, the state aquaculture policy act declares aquaculture an important investment which returns employment, fisheries enhancement, and profit for aquaculturists, and tangible state benefits. ${ }^{179}$ The lead agency is the state Department of Agriculture (FL DOA), which works with other agencies such as the state Department of Environmental Protection (FL DEP), etc. ${ }^{180}$ The state aquaculture policy act calls for a state aquaculture review council and an aquaculture interagency coordinating council to concurrently oversee the industry, then pass recommendations on to the FL DOA to be promulgated into rules and regulation. ${ }^{181}$

Under the direction of the FL DOA, aquaculture has been placed in its own division by statute. ${ }^{182}$ With this placement, the administration was tasked with promulgating a certification program, with enforcement of a shellfish culture program, and with maintenance of a leasing program for potential enterprises. Education and technical assistance programs, with the intent of public outreach, work with a state extension program to be discussed later.

\footnotetext{
${ }^{178}$ Telephone Conference, Dr. John Ewart, October 2010.

${ }^{179}$ F.S.A. $\$ 597$ Aquaculture Policy Act, et seq.

180 Id. at $§ 597.003$ et seq.

${ }^{181}$ Id. at $\$ 597.005$ et seq. \& $\$ 597.007$ et seq.

182 Id. at $§ 570.061$ et seq.
} 
The State has taken a strong proactive approach to its industry; since implementation, the State has revised its plan more than a half dozen times, with a recent modification completed for its 2011 plan just released. Aquaculture is a high priority within the levels of state government, as witnessed when referencing the State Comprehensive Plan in $2008 .^{183}$ The comprehensive plan originally began in the 1980's as prioritizing state goals and has been subsequently amended on a yearly basis to continue striving to promote and grow the state economy.

Any potential aquaculture enterprise must register with the State pursuant to Section 004 of Chapter 597. ${ }^{184}$ General operating permits for aquaculture are issued pursuant to Section 403.814 of state code. ${ }^{185}$ Specifically tailored for marine culture, permits must be obtained as part of a mandate codified under Title 28 of the state Natural Resources: Conservation, Reclamations, and Use code. ${ }^{186}$ In many situations, a state saltwater products license must be purchased for the transport and marketing of saltwater products not covered under the general permits required as part of Section 597.004. ${ }^{187}$ Do note this requirement is much different from the standard license mandate under Chapter 379 for commercial fisheries. ${ }^{188}$ A side note to mention, unlike other states that have had debates over the classification of wild $\mathrm{v}$. domesticated" aqua-cultured products, Florida has explicitly labeled the production of aquaculture to fall under the domesticated classification, given statutes referenced under Chapter $570 .^{189}$

In some parts of Florida, water management permits are required for aquaculture operations, mainly for consumptive usage, driven by the recent surge in the Everglades water

\footnotetext{
${ }^{183}$ Id. at $\$ 187.201(22)$ et seq.

${ }^{184} \mathrm{Id}$. at $§ 597.004$ et seq.

185 Id. at §379.046(3).

${ }^{186}$ Id. at $\S 379.2523$ et seq.

${ }^{187}$ Id. at $\S 379.2523(1)(c)$.

188 Id. at $\S 379.361$ et seq.

${ }^{189}$ Id. at $§ 570.073(1)(a)$.
} 
management protection. ${ }^{190}$ Based on law promulgated in 1996, water-use permits are typically issued concurrently under Title 28 and can be consolidated as a means of alleviating hefty application processes for authorization of multiple aquaculture-based activities by a single enterprise. ${ }^{191}$ Now it has been described that permitting has been removed from state regulation based on federal oversight, which creates an unnecessary burden by requiring potential producers to go to other states for the necessary documentation. ${ }^{192}$

Florida has created its own BMP's with regards to aquatic animal health standards and aquatic waste management, as set forth by the federal government (Florida Department of Agriculture, Division of Aquaculture, 2007). Under these BMP's, the State has codified legislation which provides an exemption for aquacultural pursuits compliant under Section 597.004. ${ }^{193}$ Also, important enough to mention, over 900 certified facilities currently handle product certification and waste management. ${ }^{194}$ Pollution control can be referenced under Chapter 403 of the Environmental Control code, which outlines the need for the development of the NPDES program to handle discharges, not to exclude aquaculture. ${ }^{195}$ Under statute, if an aquaculture enterprise has an annual discharge less than the minimum parameters set forth by the federal NPDES requirement, they will be exempt from wastewater management regulations. ${ }^{196}$ Likewise, another option is the general permit including the NPDES mandate for operations exceeding the annual discharge limit under Section 403.814(8). ${ }^{197}$

\footnotetext{
${ }^{190}$ Id. at 373.4595 et seq.

191 Id. at $\$ 373.1131(3)$.

192 Telephone Conference, Paul Zajack, (July, 2010).

${ }^{193}$ F.S.A. §373.406(8).

${ }^{194} \S 373.406(8)$, Infra note 193 at 42.

${ }^{195}$ FL ST $\$ 403.0885$ et seq.

196 Id. at $§ 403.0885(5)$.

${ }^{197}$ Id. at $\S 403.814(8) \&(9)$.
} 
The State has also emphasized the importance of conservation of its water resource by enacting provisions under statute directing the state Department of Environmental Protection (FL DEP) on how to regulate aquaculture operations. ${ }^{198}$ An interesting exemption is afforded to aquaculture under a pro-farming initiative referenced under Chapter 403 of the Environmental Control Code, which exempts aquaculture water management systems located within waters of the state by disregarding the enforcement of water quality standards for an agricultural water management system. ${ }^{199}$ This exemption removes unnecessary duplication of permits for multiple emitters under one visible tltimate" point of discharge. In essence, this requirement only regulates one point source when multiple emitters exist. It decreases issues with compliance and enables more efficient enforcement of discharge. In summary, the exception is known as the -storm water exemption" under NPDES.

The State of Florida can be characterized as a hybrid state of production. In fact, it is the ideal representation of why the aquaculture industry, as a whole, is a truly dynamic nontraditional form of agriculture. Aquaculture is represented and formally recognized by the state Department of Agriculture (FL DOAG), where currently one coordinator has been appointed for a solely networking capacity. Florida epitomizes the traditional American model for information dissemination. Industry officials from both the marine and freshwater sectors of state production collate knowledge with members of the state higher education institutions (universities). Academia then networks with extension positions located across the sixty-six state counties, which then disseminate the necessary information to the general public. To reemphasize the position that Florida is an aquaculture-friendly state, the DOAG has a great reference tool citing its main webpage found on the internet. DOAG currently has the Aqua farm Program Assistance

\footnotetext{
${ }^{198}$ F.S.A. $\$ 253.002(1)$.

${ }^{199}$ Id. at $§ 403.927(2)$.
} 
Program, which is a means of efficient information collation with the intent to disseminate to the general public and those interested in the state industry (Florida Department of Agriculture and Consumer Services, 2011). This particular website is very user-friendly and provides a great deal of information for anyone searching for aquaculture answers.

The current state of Florida law is the result of over two decades of intense involvement from all industry sectors, beginning with the adoption of the state Mariculture Act, which authorized the leasing of submerged lands and the vertical water column (Aspen Research and Information Center (Aspen Systems Corporation), 1981). Leasing or use of tidal waters is addressed under section 253.60 (chapter 18-31) of the state statute (Soil and Water Engineering Technology, Inc., 2008). Aquaculture enterprises seeking to operate on state lands must file an application with the FL DOA and FL DEP pursuant to statutes referenced under Chapter 253 of the Public Lands and Property code. ${ }^{200}$ Under the Public Lands Section of state code, aquaculture received adequate attention as a viable public interest to be under the control of the FL DEP to preserve aquatic preserves and urban aquatic sanctuaries. ${ }^{201}$ Such leases are required to be complaint with state mandate under Section 253.71 and 597.010. ${ }^{202}$

Under the lease contract, the enterprise must be found to operate in a manner consistent with a stated public interest or public purpose. ${ }^{203} \mathrm{~A}$ performance standard is a major requirement, as part of the potential aquaculture operating lease for state lands. If a breach of lease occurs, forfeiture much like a mineral lease will take place, where the State will assume

\footnotetext{
${ }^{200}$ Id. at $\S 253.002(1)$.

${ }^{201}$ F.S.A. $§ 258.42(1)(b)$.

${ }^{202}$ Id. at $\S 253.001(1)(b)$.

${ }^{203}$ Id. at $\$ 253.71$ et seq.
} 
ownership of all works, improvements, and plant and animals life contiguous to the land and water columns. $^{204}$

Marine aquaculture production is regulated concurrently by the FL DOA and the state Fish and Wildlife Commission (FL FWC) under Chapter 379 of Title 28, Natural Resources Code. ${ }^{205}$ The State has large vested interest in aquaculture, which is evident in its legislation to protect its shellfish aquaculture production on state lands under Chapter 253 and $597 .^{206}$ Potential aquaculturists should note that the state values adequate use of state lands and has implemented legislation to protect the use of zones," where aquaculture leases may allow production to occur. ${ }^{207}$ If the state Department of Fish and Wildlife Conservation (FL DFW) finds nonproductive zones" or areas where the environment is adversely affected, recommendations may be made which prohibit or limit the use of zones". This precaution is environmentally friendly, which protects the native habitat from misuse or any degrading harm. While the State is certainly vigilant with its efforts to protect state lands, it does promote developing aquatic preserves as a viable source for aquaculture production. ${ }^{208}$

However, more importantly is production that occurs throughout the State. Much of the manner of production in Florida is via small, private farms, which view day-to-day operations as a means of profit-driven survival in a downed economy. The product being propagated is diverse. Currently, 1500-1800 species are cultured in the state of Florida, where markets exist for food fish, commercial recreational sport fishing and a major percentage of the U. S. ornamental fish production. ${ }^{209}$

\footnotetext{
204 §253.71 et seq., Infra Note 203 at 44.

205 F.S.A. $\$ 379.2521$ et seq.

${ }^{206}$ F.S.A. $§ 253.72(3)$.

207 Id. at $\$ 253.75$ et seq.

${ }^{208} \S 253.75$ et seq., Infra Note 207 at 45.

${ }^{209}$ Paul Zajack, Infra Note 192 at 42.
} 
As a coastal state, Florida recognizes the importance of environmental protection; in fact, much of the aquaculture enterprises operate in or around tidal and such contiguous areas. Industry input on conservation boards is vital to a working relationship to continue balancing both industry growth and environmental management. One example of industry cooperation can be referenced under Chapter 161 of the Beach and Shore Preservation code, where members from industry are appointed by the FL DOA to hold a position on the Florida Oceans and Coastal Council. $^{210}$ This council oversees relevant research to monitor activities occurring in coastal environments; aquaculture's appointment, however, is to solely achieve sustainable marine focused culturing of safe and viable products. ${ }^{211}$

According to statute referenced under Title 12 of the Municipalities code, aquaculture as an agricultural purpose" receives an exemption from the normal levied tax on the purchase of bottled gas or fuel oil required for the operation of such enterprise. ${ }^{212}$ The similar agricultural purpose" classification places aquaculture also under the reference for Taxation and Finances Code, Title $14 .^{213}$ This reference is significant to aquaculture if an operation chooses to operate on land either reclassified non-agricultural or is no longer being used for the state agricultural purposes, then the property is subject to state appraisal and zoning pending a request of the local municipality. $^{214}$

\section{Georgia}

The State of Georgia traditionally has been a small producing state, largely due to a lack of formal acknowledgement of the aquaculture industry until lately. Like many of the remaining small producing states, Georgia has been faced with setbacks to development. Funding has been

\footnotetext{
${ }^{210}$ F.S.A. $\$ 161.73(3)$.

${ }^{211}$ Id. at $\$ 161.74(\mathrm{i})$.

212 Id. at $\$ 166.231(4)(b)$.

${ }^{213}$ Id. at $\S 193.461(5)$.

${ }^{214} \$ 193.461(5)$ Infra Note 213 at 46.
} 
an issue, which has resulted in the deletion of an aquaculture coordinator position. Subsequently, state regulatory officials currently employed are charged with the tasks normally assigned to that position, which include permit enforcement, inter-agency coordination, registration and compliance checks and acting as an intermediary with the state regulatory agencies and the industry sector. Because of the current economic downturn faced by all agricultural sectors, the State of Georgia has taken a different marketing approach by offering free registration for new" producers. This incentive-based registry will hopefully stimulate growth within the state industry.

Originally, a development act aimed at promoting pacific white shrimp was established under statute, but then later repealed in $2008 .^{215}$ The development act placed aquaculture originally under control and husbandry of the state Department of Agriculture (GA DOA). ${ }^{216}$ Interesting to note, the State of Georgia outlined permit registration pursuant to $\$ 2-15-6,7^{217}$ The GA DOA was responsible under statute to set rules and regulation to ensure best management practices (BMP's) with regards to efficient and safe Pacific Shrimp culturing. ${ }^{218}$ Do note that explicit in the language of all of this legislation was that it was subject to appropriation of funding, based on laws promulgated in 2004. Mandatory inspections were mandated under the act. $^{219}$ Reading along the varied sections of the act, each provision was subject to fiscal appropriation, which was the reason for the statutory repeal. ${ }^{220}$ In the absence of formal recognition, the Georgia Department of Natural Resources (GA DNR) assumed regulatory authority of the state industry.

\footnotetext{
${ }^{215}$ Ga. Code Ann., §2-15-1.

${ }^{216}$ Id. at $\$ 2-15-2$ (Definitions).

${ }^{217}$ GA ST. §2-15-6.

${ }^{218}$ Ga. Code Ann., §2-15-12(b).

${ }^{219}$ Id. at §2-15-14.

${ }^{220}$ Telephone Conference, Michael Spencer, (June, 2010).
} 
Despite the current State of the Georgia aquaculture industry, the state has implemented formal statutes, which recognize aquaculture as a viable industry for the State under §391-4-14, taken from the (GA DNR) website (Georgia Department of Agriculture, N.D.). Under §391-414 , registry applications and revocation information is specifically outlined.

Water Use Permits are required for industries such as aquaculture that will require withdrawal, divergence, or impounding of any of the state surface waters. ${ }^{221}$ Permits are required for surface water usage according to research conducted outlining Article Two, Chapter Five of the Water Resources Code. ${ }^{222}$ This provision protects domestic use of state waters, while promoting agricultural-based industries at the same time: in essence it accounts both for economic and ecological considerations together. But at the same time, wetland protection preempts state economic development of aquaculture, so a fine distinction is made to consider both areas in the decision making process. ${ }^{223}$

Initial research reveals that the early legislation suggested a state vested interest in Pacific Shrimp culture. When the legislature failed to appropriately fund for the industry, all of the early legislation was repealed. Most recently, aquaculture support has resulted in the passage of fish production legislation. In fact, under Chapter 4 of Title 27, labeled the Game and Fish code, aquaculture development was promulgated for fish. ${ }^{224}$ Upon first glance, the same appropriations disclaimer headed the development act. Georgia codified under the act to create an aquaculture focused development commission (GA ADC), comprised of a 14 member board,

\footnotetext{
${ }^{221}$ Ga. Code Ann., § 12-5-31(a)(1).

${ }^{222}$ Id. at $\S 12-5-31(b)(3)$.

${ }^{223}$ Id. at $\S 15-5-288(b)(6)$.

${ }^{224}$ Ga. Code Ann., T.27, Ch.4, Article 6, Aquaculture Development.
} 
to pass recommendations resulting in an amended aquaculture development plan, eventually to facilitate the continued growth of the state industry. ${ }^{225}$

As set forth by state mandate under the law, GA ADC is charged with creating an aquaculture development plan, which says under $§ 27-4-254$ the following will be completed:

(1) An evaluation of Georgia's natural resources as they relate to aquaculture;

(2) An evaluation of species with potential for culture in Georgia;

(3) An identification of constraints to development of aquaculture in Georgia and recommendations on methods to alleviate these constraints;

(4) An identification of the roles of the Department of Agriculture and the Department of Natural Resources in supporting the aquaculture industry, including an evaluation of existing physical and personnel resources and recommendations for allocation of additional resources where needed;

(5) Recommendations for implementation of the plan; and

(6) An identification of the role of other state and federal agencies in the development of the aquaculture industry. ${ }^{226}$

Mandatory registration with the state Department of Natural Resources (GA DNR) is stated under the act. ${ }^{227}$ Unlike many states, Georgia was explicit in its application process and content for compliance through the language of its act. With regard to rules and regulation, the state aquaculture board, concurrent with both the assistance of the state development commission and GA DNR, were to create enforceable standards for the industry. ${ }^{228}$ The act went so far as to require mandatory authorized inspections of aquaculture operations. ${ }^{229}$ The State of Georgia has taken a firm stance to develop the industry because it realizes that the industry is in the public's interest. However, until this current economic climate steadies, possible development is threatened.

\footnotetext{
${ }^{225}$ Id. at $§ 27-4-253$ et seq.

${ }^{226}$ Id. at $\$ 27-4-254$.

227 Id. at §27-4-255.

${ }^{228}$ Id. at §27-4-262.

${ }^{229}$ Id. at §27-4-263 et seq.
} 


\section{Hawaii}

Drawing upon the federal codification in the early 1980's, the State of Hawaii began its transformation into the most efficient industry for information dissemination rivaling Florida. ${ }^{230}$ Therefore, first, the state initially declared police power for the development of marine resources utilizing waters of the state. A condemnation process occurred pursuant to vested public use, cited as procedural right to take, for agricultural development. ${ }^{231}$ Following, the State has permitted the leasehold access of lands to native Hawaiians for the purpose of agricultural sector development. $^{232}$

Taken from 1920 state law, the state Department of Agriculture was authorized to employ an -expert" for aquacultural enterprise development under Title 2 of the state Hawaiian Homes Commission provisions. ${ }^{233}$ Early in its industry development, the State of Hawaii understood the importance of water conservation, so water regulation was passed under the same title to license rights to use governmental-owned waters" by the state promulgated board of land and natural resources. ${ }^{234}$ Based on more recent legislation, a leasing program promulgated under the Public Lands code, referenced under Chapter 171, allows aquaculture enterprises the opportunity to enter into lease agreements to develop agricultural pursuits. ${ }^{235}$

Hawaii has always been viewed by the aquaculture community as a progressive state, with regard to management and development. Perhaps this is due to the nature of the State being an island, whereby all food sources must be either produced locally or must be imported at great expense. The sustainable development of agriculture centers helped to offset any fiscal burden

\footnotetext{
${ }^{230}$ National Aquaculture Policy Act, Infra Note 1 at1.

${ }^{231}$ Hawaii Const. Art. 11, §6.

${ }^{232}$ HHCA §207, (HRS § 190D-33).

${ }^{233}$ HHCA 219 (1921). \& $220(d)$.

${ }^{234}$ HHCA $\$ 221$ et seq.

${ }^{235}$ Id. at $§ 171-36$ (b) et seq. \& (c) et seq. \& (d) et seq.
} 
created by their isolation from the mainland. Additionally, the social culture of the Hawaiian Islands, as a whole, places value on the conservation of its readily available water resource. Ecotourism and Agritourism have required the efficient management of this resource for the public's benefit, which comprises a large sector of the state's economy. In essence, this has resulted in all facets of the state economy being interrelated and equally important. Aquaculture is referenced in the state water code under Chapter $174 \mathrm{C}$ for purposes of domestic or agricultural uses. ${ }^{236}$ Following, the State implemented a water resource protection plan, which controls the use and development of agriculture and industrial sectors to include aquaculture. ${ }^{237}$

In 1959, the State recognized the need for formal aquaculture development, placing its priority under the Department of Agriculture (HI DOA). ${ }^{238}$ Under the recommendation of the state legislature and the direction of the HI DOA, aquaculture was codified under Chapter 141 of the state code. ${ }^{239}$ Funding was appropriated for the aquaculture development program to implement disease management programs and to support research and development for the state industry. ${ }^{240}$ Prior to 2000 , the State had an aquaculture advisory council, dually listed under both the state aquatic resources and wildlife and agriculture and animals codes, which both have since been repealed. ${ }^{241}$

Under the Conservation and Resources portions of the code, aquaculture is referenced with regard to harvest permits, based on law codified in 1985 and subsequently amended in $1987{ }^{242}$ Under that same title, there are provisions for aquatic resources, specifically which

\footnotetext{
${ }^{236}$ Id. at $\S 174 C-2$.

${ }^{237}$ Id. at $\S 174 C-31$.

${ }^{238}$ HRS $\S 26-16$ (c) (4).

${ }^{239}$ Id. at $\S 141-2.5$.

${ }^{240}$ Id. at $\S 141-2.7$.

${ }^{241}$ Id. at $\S 148(D)(1-5)$. \& $\S 189(g)$. Repealed by Laws 1998, Ch. 176, §10. \& Laws 2000, Ch. 71, § 1.

${ }^{242}$ Id. at $\S 183 D-61(3-4)$.
} 
include products cultured as a means of aqua cultural enterprises. ${ }^{243}$ Licensure issues are discussed under the aquatic resources chapter. ${ }^{244}$

The legislature had vested much time and money into aquaculture development; therefore, provisions were set to record and analyze developmental growth for the industry under Title 13 of the Planning and Economic Code. ${ }^{245}$ Included in that same section, agricultural districts, along with aquaculture enterprises, were characterized and grouped together regarding production and regulation was passed to control land use. ${ }^{246}$ Much like the State of Louisiana, Hawaii enacted a comprehensive coastal zone management plan, (CZM), to incorporate development of aquacultural enterprises for state delegated management areas. ${ }^{247}$ This law was passed in 1986, later amended in 1989, and basically has not been updated since. Understanding that fiscal access burdens new enterprises, the state enacted a specific aquaculture loan program under Chapter 219. ${ }^{248}$ The significance of this promotion emphasizes the state's vested interest in aquaculture development by encouraging access for new business startup. Economic priority is again represented under Title 13 of the state code, which outlines the promotion of aquaculture statewide. $^{249}$ Hawaii has proposed an agricultural focused education program that creates curriculums centered on aquaculture. ${ }^{250}$

The State also has implemented an aquaculture development fund, appropriated through Chapter 190D of the Ocean and Submerged Lands Leasing code for state marine waters. ${ }^{251}$ The language of Chapter 190D-33 explains any revenue obtained from this program shall go to the

\footnotetext{
243 Id. at $\S 187 \mathrm{~A}-1$.

${ }^{244} \mathrm{Id}$. at $\S 187 \mathrm{~A}-3.5$.

245 Id. at $\S 201-19(a)(1)(G)$.

246 Id. at $\S 205-2(d)(3)$.

${ }^{247}$ Id. at $\S 205 A-44(b)(4)$.

${ }^{248}$ Id. at $\S 219-1$ et al.

${ }^{249}$ Id. at § 226-103 et seq.

${ }^{250}$ Id. at $\S 302 A-431.7$ (b) \& (e).

${ }^{251}$ Id. at $\S 190 D-33$ et seq.
} 
planning, research, and development of state aquaculture. This endorsement represents the state's position on the value of aquaculture. In fact, it is even stated that aquaculture exists as a matter of state policy under statute to solidify this point. ${ }^{252}$ Hawaii has long viewed aquaculture as a means of facilitating employment growth, a benefit that diversifies its economy, plus it is a renewable form of sustenance. ${ }^{253}$ This declaration was based on legislation promulgated over 30 years ago.

To reiterate the state's devotion to environmental protection, an environmental policy act was established under Chapter 344 of the code. ${ }^{254}$ This consideration notes Hawaii's position on protection of the environment, in conjunction with continued agricultural growth and promotion. Aquacultural enterprises are required to account for any potential impact to the environment pursuant to the Hawaii's version of NEPA, the Hawaii Environmental Policy Act (HEPA). ${ }^{255}$

A telephone conference with the state NASAC contact confirmed that state producers culture yellowtail and pacific threadfin, while technology for open-ocean culturing is in the research and development phase for yellow fin tuna culture. With regard to aquatic animal health, specific pathogen testing occurs, since importation of products does occur from Asia, to ensure food security for the islands. However, at this time, no official importation regulation exists as they are still in the draft phase. ${ }^{256}$

\section{Idaho}

The state Department of Agriculture in Idaho (ID DOA) has declared aquaculture to be an agriculture pursuit; and it is a matter of state policy to promote state development. ${ }^{257}$ The

\footnotetext{
${ }^{252}$ HRS $§ 226-7(b)(12)$.

253 Id. at $\S 226-10(b)(1)$.

${ }^{254}$ Id. at $\S 344-4(5)$ et seq.

${ }^{255}$ Id. at § 344(10.5).

${ }^{256}$ Telephone Conference, Todd Low, October 2010.

257 I.C. $§ 22-103(4)$.
} 
majority of aquaculture references under statute now lie in Chapter 44 of the Agriculture and Horticulture Code, pursuant to Title $22 .^{258}$ The state legislature acknowledged the economic capacity aquaculture brought to the state, so what resulted was a codified chapter, dedicated to the promotion of the industry. Under the aquaculture chapter, a state industry commission was created, comprised of five members appointed by the governor. ${ }^{259}$ The commission's duties are outlined under Section 4404, which explicitly describes the duty to oversee record keeping for the state industry and to conduct promotional activities further enhancing product marketability.

The commission must also perform the important task of disseminating accurate information to the public, concerning the value of aquaculture products. ${ }^{260}$ An odd occurrence was found under Chapter 44, where Section 4409 allows for an who elect not to comply with record reporting or other measures of the chapter. ${ }^{261}$ This statutory provision appears to violate the stated goals of accurate record keeping and information dissemination, which comprise the root of Chapter 44. Section 4409 holds producers to a goodfaith effort for reporting and compliance, basically rendering the chapter toothless." By not mandating a compliance standard, how can a state regulatory agency efficiently disseminate accurate industry information?

Based on law codified in 1992 and later amended in 1994, state aquaculture facility regulation is handled by the ID DOA. Management rules can be referenced under Title 22, Chapter $46 .^{262}$ On-site inspections, standards for fish health maintenance, and marketing protocols are outlined under this chapter as well. Waste disposal measures are outlined by the

\footnotetext{
258 ID ST §22-4401 et seq.

${ }^{259}$ Id. at $\$ 22-4403$ et seq.

${ }^{260}$ Id. at $\$ 22-4404$ et seq.

${ }^{261}$ Id. at $\$ 22-4409$ et seq.

262 Id. at §22-4603 et seq.
} 
Health and Safety Code under Title 39, Chapter $1 .^{263}$ Both Chapters 1 and 46 work together to ensure aquaculture facility compliance for the state. In Idaho, aquaculture operations must comply with state waste management guidelines by comprising a management plan regulated by the state Department of Environmental Quality (ID DEQ).

Normally, the ID DEQ is the lead agency for water quality. But due to such demand, the ID DOA oversees aquaculture specifically. ${ }^{264}$ Idaho was an interesting state to research concerning water rights because, under statute, the legislature created water measurement

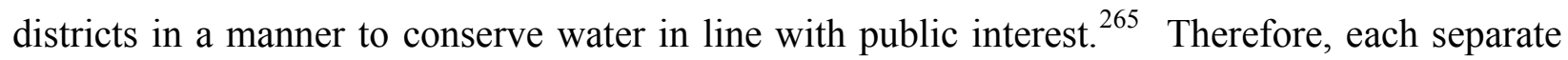
water source constitutes a -district" with an appropriator.

\section{Illinois}

Under Article 205, the Illinois Department of Agriculture (IL DOA) has the power to develop and implement aquaculture focused programs pursuant to the state development act. ${ }^{266}$ The state aquaculture development act, codified in January of 1988, can be referenced in Act 215 under Chapter 20 of the Executive Branch statutes for the state. ${ }^{267}$ Originally, the act was established to promote the state industry and other related economic activities of the State. ${ }^{268}$ Under the provisions of Act 215, the IL DOA is tasked as lead agency. ${ }^{269}$ The state aquaculture advisory committee was directed under section $215 / 6$ of the act, which mandates a 12 member

\footnotetext{
${ }^{263}$ Id. at $§ 39-118(5)$ et seq.

${ }^{264}$ Id. at $\$ 39-3602(8)$.

265 Id. at $42-706$ et seq.

266 ILCS $\$ 205 / 205-60$.

26720 ILCS $\$ 215 / 1$.

268 IL ST CH $\S 20$ §215/3.

${ }^{269}$ Id. at $\S 215 / 5$ et seq.
} 
board representing all sectors of the state industry. ${ }^{270}$ Under the act, an aquaculture cooperative was to be created, but has since been repealed following an amendment to state law in $2009 .{ }^{271}$

In 1990, the State enacted statutes which protected potential aquaculture enterprises from zoning restrictions, which may restrict industry growth in the state. ${ }^{272}$ To help stimulate growth and development, the State codified a statewide Agri-first Program," referenced under Act 19, for agricultural industries including aquaculture. ${ }^{273}$ The legislature acknowledged in 2001 that the state agricultural economy was stifled due to a long list of constraints, thus this legislation was promulgated with the intention of eliminating the hindrances to development. While aquaculture lacks a direct surge in political influence, it does benefit from its agricultural sisterindustries that also suffer. The legislature has found that an $\mathrm{Ag}$-Wide" push for development serves the public's best interest.

Now, most of regulatory oversight for the state industry comes by way of the state Department of Natural Resources (IL DNR) (North Central Regional Aquaculture Center, 2008). The IL DNR aquaculture regulation exists under sections 870.50 of the administrative code known as the fish rule". ${ }^{274}$ Based on legislation passed originally in 1990, aquaculture permits are required for compliance with the IL DNR. ${ }^{275}$ Since 1992, fish health requirements and species importation permit compliance can be referenced and checked under Section 5/10-105 under the IL DNR regulations. ${ }^{276}$ Illinois has a strict, non-indigenous (non-native species) importation requirement that must be checked with the IL DNR for both aquaculture and stocking purposes.

\footnotetext{
${ }^{270}$ Id at $\S 215 / 6$.

${ }^{271} 20$ ILCS $\S 215 / 5.5$. Repealed by P.A. 93-839 (June 2009).

27255 ILCS $\S 5 / 5-12001$

${ }^{273} 505$ ILCS $\$ 19 / 5$ et seq.

27417 ILL. ADM. CODE $§ 870.50$.

${ }^{275} 515$ ILCS 5/5-5 et seq.

${ }^{276} 515$ ILCS §5/10-105.
} 
State requirement for facility permits can be referenced under section 5/20-90. ${ }^{277}$ A dead animal disposal act under Chapter 225 of the state food and agriculture code affects state aquaculture. ${ }^{278}$ In an effort to protect the public from pesticide introduction through aquaculture product consumption, the state has declared agricultural commodities", including those cultured from aquaculture facilities, to be subject to regulation under the state Pesticide Act under Chapter $415 .^{279}$ Also, pursuant to Act 215, the state has similar language to conserve agriculture areas" to include aquaculture intensive areas under Act 5 of Chapter $505 .^{280}$

Administrative rules for sport fishing are by code reference. ${ }^{281}$ Further research into Illinois rules explains aquaculture has rules for the transportation, importation, and possession of fish under code as well. ${ }^{282}$ The State has enacted rules to protect aquaculture stock from contamination with Viral Hemorrhagic Septicemia (VHS). ${ }^{283}$ A telephone conference with the state NASAC contact revealed that state producers grow hybrid striped bass, largemouth bass, channel catfish, freshwater prawns, tilapia, rainbow trout, and various other species. ${ }^{284}$ Viral Hemorrhagic Septicemia (VHS) is a concern for aquatic fish health in the state, and regulators are vigilant in their approach to prevent outbreaks of this epidemic (Whitledge \& Hitchens).

\section{Indiana}

A potential aquaculturist can reference statutes pertaining to aquaculture in Indiana under Chapter 3.8 of Article $4 .^{285}$ Under Chapter 3.8, the State Department of Agriculture (IN DOA) has assumed control as lead agency. Section 2 mandates the IN DOA to encourage the

\footnotetext{
${ }^{277}$ Id at $\S 5 / 20-90$.

278 ILCS Ch. 225, ACT 610, Refs \& Annos.

279415 ILCS $\S 60 / 4(4)$.

${ }^{280} 505$ ILCS 5/3.02 et seq.

281 ILL. ADMIN. CODE 810: Sport fishing Regulation.

282 Id. at 870: Aquaculture, Transportation, Importation, \& Possession Rules.

283 Id. at 875: VHS Rules.

${ }^{284}$ Telephone Conference, Delayne Reeves, July 2010.

285 IN ST 4-4-3.8 et seq., (Indiana Aquaculture).
} 
development and growth of aquaculture in the State by instigating" the formation of a market and development plan for the industry. ${ }^{286}$ The state legislature inserted language under Chapter 3.8 to provide potential aquaculture enterprises access to financial support, which is entitled to other sectors of the state agricultural industry. ${ }^{287}$ In line with Section 3 of Chapter 3.8, the State also included aquaculture to be affected by statutes referencing the Indiana Development Finance Authority, pursuant to Chapter $11{ }^{288}$ Chapter 11 authorizes the State to employ aquaculturists as a matter of public interest.

Following the State's initial interest in aquaculture development, the industry then was transferred to Chapter 7, where further promotion has expanded industry reference. ${ }^{289}$ Under Chapter 7, similar duties were delegated to the IN DOA, to include market formation and development plan implementation, but new goals were outlined. Of those, the IN DOA was encouraged to promulgate education programs, focused at sparking industry interest by advocating farming diversification" and not to exclude the creation of an annual reporting program for the industry. ${ }^{290}$

The State has an invasive species control council, where aquaculture holds a seat under the direction of the IN DOA. ${ }^{291}$ The Purdue University School of Agriculture lobbied for the creation of this council which, following its establishment of the 11 member council under statute, is required to recommend rules and regulations concerning invasive control to the state legislature. The council is also tasked with developing an invasive species inventory to include a

\footnotetext{
${ }^{286}$ Id. at $\S 2$ et seq.

${ }^{287}$ Id. at $\$ 3$ et seq.

${ }^{288}$ IC 4-4-11-15(7).

${ }^{289}$ IN ST 15-11-7-1 et seq., (Indiana Aquaculture Promotion). Added by P.L.2-2008, Sec.2.

${ }^{290}$ Id. at §2 et seq., (Revised Duties of IN DOA).

${ }^{291}$ Id. at $15-16-10-5$ et seq.
} 
data management system and to communicate with other state and federal agencies in order to enhance the effectiveness of their preventive measures. ${ }^{292}$

The State has addressed the industry-wide debate over wild v. domestic" classification of products by stating explicitly, under Article 17, Chapter 2, that it declares any aquatic animal subject to aquaculture is a -domestic animal.,"293

\section{Iowa}

Based on 1980 legislation, aquaculture is referenced as an agricultural farming practice” under Chapter 175 of the Iowa Agriculture Development Code. ${ }^{294}$ The majority of statutes, however, appear to be referenced under Title 11 of the Natural Resources Code. ${ }^{295}$ Under Title 11, ownership of all fish or aquatic organisms cultured by aquaculture enterprises is outlined to either be property of the State or of a specific private business owner. ${ }^{296}$

Since 1992, Aquaculture unit licensure requirements pursuant to Section 141 must be met before any person may engage in the business of aquaculture in the State. ${ }^{297}$ The State has declared an operating license is not required for operating aquaculture «nits" from private ponds or non-meandered lakes and streams. This exemption benefits privatized aquaculture to grow so long as their production does not affect the native species or fauna-inhabiting waters of the state. The activities regulated for licensure compliance are outlined under Section $142 .^{298}$ State bait dealer licenses may be obtained on a conditional basis, where statute provisions are met according to Section $144 .{ }^{299}$ According to the language of the statute under Section 141, tropical

\footnotetext{
292 Id. at $\$ 4$ et seq.

293 IC 15-17-2-26(b)(3). Added by P.L.2-2008, Sec.8.

294 I.C.A. $\$ 175.2(\mathrm{k})$.

295 Id. at §481A.1 (3),(4),(28).

${ }^{296}$ Id. at $\$ 481 A .2$ et seq.

${ }^{297}$ Id. at §481A.141(1).

298 IA ST §481A.142 et seq.

${ }^{299}$ Id. at $§ 481$ A.144 et seq.
} 
ornamental production is regulated, which is interesting considering Iowa is a state far from coastal borders. ${ }^{300}$ The state aquaculture unit license fee may be referenced by statute under Chapter 483A, which has been amended multiple times following $1990 .^{301}$

According to a telephone conference with NASAC contact, Rich Clayton, Iowa aquaculture is a unique and necessary entity to U.S. production. Its numbers, however, are significantly less than production in states like Florida or Mississippi. The State of Iowa currently operates under a joint regulatory structure which includes: the Department of Natural Resources (DNR) and Department of Agriculture (DOAG) acting as a cohesive regulatory unit. Approximately 50-60 producers licensed through the state DNR produce baitfish and koi for recreational restocking and wholesale production marketing.

Iowa's permitting structure follows a simple procedure as required by the state DNR, who handles all licensing of fisheries. Marketing of aquaculture products is handled through the state DOAG. Currently, Iowa State University acts as the main extension service for aquaculture, where courses are taught at the B.A., M.S., and PhD level, focusing on Animals Ecology, supported by a strong fisheries emphasis. The Iowa Aquaculture Association acts as the advisory council for the state's industry. ${ }^{302}$

\section{Kansas}

Under Chapter 47, Article 19, state aquaculture in Kansas is referenced since 1992. ${ }^{303}$ Under Article 19, the state legislature tasked the State Department of Agriculture (KS DOA) to act as tead agency" and coordinate all industry focused activities, not to exclude the draft and

\footnotetext{
${ }^{300}$ Id. at $\S 481 \mathrm{~A} .141(\mathrm{~b})(3)$.

${ }^{301}$ Id. at $§ 483 A .1(1),(2)$., Added by Acts 2001 (79 G.A.), Ch. 148. et seq.

302 Telephone conference, Rich Clayton, August 2010.

${ }^{303}$ KS ST 47-1901 et seq., Kansas Aquaculture Development.
} 
execution of a state development plan. ${ }^{304}$ Kansas, unlike other states, explicitly classifies aquaculture as agriculture under Article 19. ${ }^{305}$ Most other states place this declaration under separate areas of state code. Originally, the State promulgated an aquaculture advisory council under S.B. 203 in 1992; however, its existence has since been repealed. ${ }^{306}$

The State has created a promotional fund to help financially assist research and development for the industry. ${ }^{307}$ Even back in 1992, the legislature recognized that production was small so that the State attempted to remove fiscal constraint to the industry by exempting the industry from ad valorem taxes on machinery and equipment. ${ }^{308}$

A telephone conference held with the state NASAC contact confirms that production is small for Kansas. In 2005, the value of products cultured by aquaculture reached $\$ 375,000$ dollars U.S. Because production levels are small, waste discharge pursuant to the federal NPDES requirement is not triggered. The State has also not declared primacy with regard to its aquatic animal program, since industry production is so small. Fiscally speaking, it is cheaper to follow federal guidelines than petition for a separate program which would require intensive capital oversight. Kansas does have significant assistance from higher education at Kansas State University. ${ }^{309}$

\section{Kentucky}

In 1998, the Kentucky Aquaculture Task Force was created under the direction of the state Department of Agriculture (KY DOA), referencing Title 21 Chapter 246, comprised of 13

\footnotetext{
${ }^{304}$ Id. at §47-1902(a).

${ }^{305}$ Id. at \$47-1905(c).

${ }^{306}$ Id. at $\S 47-1903 .$, Added by Laws 1992, Ch. 102, §11., (S.B. 203)., Repealed by Laws 2006, Ch.16, §2.

${ }^{307}$ Id. at $§ 47-1905$ et seq.

${ }^{308}$ K.S.A. $79-201 \mathrm{j}(\mathrm{b})(1)$.

${ }^{309}$ Telephone Conference, Randy Nelson, July 2010.
} 
members appointed by the governor. ${ }^{310}$ The goal of this task force was to research and draft a development plan for aquaculture. Roughly ten years ago, the State of Kentucky implemented their aquaculture development plan under Chapter 260, the Marketing of Agricultural Products Code. ${ }^{311}$ In that section, the general assembly recognized the importance of aquaculture for the agricultural economy of the state. The KY DOA serves as the lead agency, providing marketing and promotion possibilities for this fledgling production state. ${ }^{312}$ Under the legislative mandate pursuant to Section 960(3), the KY DOA will work concurrently with other agencies to coordinate development and industry oversight.

During the research phase, it was interesting to find that the state tax code references aquaculture as agricultural land," under statute potentially subject to exemption. ${ }^{313}$ A grant program was established under statute for the construction of commercialized aquaculture operation ponds. ${ }^{314}$ In lieu of its findings in 2002, the legislature called for a study committee to assist in promotion under Parks and Tourism, referenced under Chapter 148. ${ }^{315}$ Later in 2010, this study committee was repealed under HB $166 .^{316}$

A telephone conference with the state marketing representative, Angela Caporelli, noted that the state industry lacks a centralized processor. This failure to have readily available processing for products makes aquaculture an expensive business venture for most private operations. Currently, production is small enough to allow the State to not exceed federal mandate under NPDES discharge program, but rather implements an informal version of BMP's. The species cultured in Kentucky range from paddlefish, tilapia, baitfish, freshwater prawns to

\footnotetext{
${ }^{310}$ KRS T. XXI, CH. 246, §1., Kentucky Aquaculture Task Force.

${ }^{311}$ KRS $\$ 260.960$ et seq. (KY ST $\left.\S 260.960\right)$.

${ }^{312}$ KRS $§ 246.010$ (5)(d), $\S 260.960(3)$.

${ }^{313}$ KRS $\$ 132.010(9)(b) . \&$ KRS $\S 139.480$.

${ }^{314} 200$ KAR 35:020.

${ }^{315}$ KRS § 148.840

${ }^{316} 2011$ Kentucky Laws Ch.19 (HB 166).
} 
hybrid striped and largemouth bass for the state restocking program initiative. Most operations are limited to small private operations. ${ }^{317}$

\section{Louisiana}

In 2003, the state legislature of Louisiana investigated potential constraints to agricultural development. The results indicated both that the state recognizes aquaculture as an agriculture industry and also that access to available capital investments stifles aquaculture or any other mariculture project. ${ }^{318}$ As a progressive state, Louisiana amended legislation originally codified in 1983, implementing the Louisiana Agriculture Finance Act to include aquaculture, so to invest and further alleviate these acknowledged fiscal constraints. Pending the results of the state legislative investigation, an agricultural finance authority was codified under Title 3 of the Agriculture and Forestry Code, tasked with alleviating fiscal tensions on agricultural sectors, directly affecting aquaculture. ${ }^{319}$ Around the same time period that Louisiana investigated fiscal concerns for agricultural industries, it also formed an informal task force to research aquaculture potential under Chapter 3-C of the Louisiana Agriculture Development Act. ${ }^{320}$ The task force held the following:

Eouisiana residents rely on Louisiana farmers and agricultural processors as their primary source of safe, nutritional, and affordable food. Furthermore, agriculture and industries are a major source of employment for Louisiana residents. The financial survival of these industries in Louisiana is dependent on increasing markets for Louisiana products. For this reason, the legislature finds it necessary to encourage and promote markets in Louisiana for the sale of Louisiana agricultural and aquacultural products. ${ }^{, 321}$

To date, the research conducted by the agricultural task force has now come to be referenced as the state aquaculture development act under statutory revision in $2004 .{ }^{322}$ Early on,

\footnotetext{
${ }^{317}$ Telephone Conference, Angela Caporelli, (August, 2010).

${ }^{318}$ LSA-R.S. 3:262(b).

${ }^{319}$ Id. at $3: 264(b)$.

${ }^{320}$ Id. at 3:291.

${ }^{321}$ Id. at 3:291 (Legislative Finding).
} 
the State recognized the potential that aquaculture production provided for the state economy and for the nations' fish demand. Subsequently, this act followed with goals to provide a solid framework for development and maintenance of the state agriculture sector. ${ }^{323}$ Promulgated under the 2004 act, the state aquaculture coordinating council was created as a 15 member board, consisting of regulatory officials and industry representatives. ${ }^{324}$ Recent amendment has repealed the existence of the council under statute. ${ }^{325}$ The state act codified regulation for production licensure. ${ }^{326}$ Facility inspections are to be conducted under the supervision of the state Department of Agriculture and Forestry (LA DOA). ${ }^{327}$

The marketing of agricultural products are handled by the LA DOA under Chapter 6, Title 3 of the Agriculture Code. ${ }^{328}$ In 2004, the State codified a state-driven, board of animal health to include aquaculture as a viable agriculture industry. ${ }^{329}$ Two members representing the industry are nominated by the state Senate Legislative Agriculture committee. ${ }^{330}$ Under the state board of animal health, regulations pursuant to the transportation of diseased or deceased products were passed, directly affecting aquaculture. ${ }^{331}$ To prevent invasive pathogen introduction, regulations were also passed to protect native species under statute. ${ }^{332}$

Following in line with other nearby southern states, in 2009, Louisiana promulgated species specific regulation, noting for catfish respectively under Chapter $30 .^{333}$ In summary, the state catfish law set out to accomplish many goals to include: establishing and developing a

\footnotetext{
322 Id. at 3:559.1

${ }^{323}$ Id. at 3:559.2(c).

${ }^{324}$ LA LEGIS 865 (2004) (§559.4). (Originally, LA R.S. 3:559.4-5).

${ }^{325}$ ACTS 2010, No. 743, §2(c), eff. 1 July, 2010. - (repealed §599.4, 599.5).

${ }^{326}$ Id. at $§ 559.8$ (LA R.S. §3:559.8).

${ }^{327}$ Id. at $\S 559.9$ (LA R.S. §3:559.9).

${ }^{328}$ LSA- R.S. 3:561 et seq., LSA- R.S. 3:663 et seq.

${ }^{329}$ Id. at 3:29091 et seq.

${ }^{330}$ Id. at 3:2091(16).

${ }^{331}$ Id. at 3:2097(3).

${ }^{332}$ Id. at 3:2658.1 et seq.

${ }^{333}$ Id. at 3:4732 et seq.
} 
thorough market for catfish demand, providing high-quality products, protecting product misrepresentation, and disseminating accurate information to the public to promote aquaculture as a whole. ${ }^{334}$ Pursuant to the catfish law's goals, statutes have been promulgated to protect product disparagement" or the dissemination of false information, as it may pertain to perishable agricultural products. ${ }^{335}$ The state's vested interest in aquaculture is served to protect public perception about the quality and quantity of products being processed within the State. This could explain why the State spent time and money to enact statutory protection for its agricultural products.

Under the 2009 legislation, a seafood safety task force was implemented. Under the Department of Health and Hospitals, this task force was charged with evaluating inspection methods of imported seafood, the frequency thereof, and for determining what substances are being tested. ${ }^{336}$ Pursuant to Section 327(b), individuals may not sell seafood products not registered and certified with the Department of Health and Hospitals. ${ }^{337}$ Under the same section, the legislature was specific in its decision to exclude live specimens of fish so as not to conflict with other sections of code which already regulate importation of live products. ${ }^{338}$ Louisiana has implemented an aquatic invasive species council basically to oversee the biological integrity of native species in $2004 .^{339}$ Under the Wildlife and Fisheries Code, Title 56, the legislature sets out license requirements for domesticated aquatic organisms, including transportation and

\footnotetext{
${ }^{334}$ Id. at 3:4732 (Definitions).

${ }^{335}$ Id. at 3:4502.

${ }^{336}$ Id. at $40: 5.5 .3$.

${ }^{337}$ Id. at 56:327(b)\& “b(1)”., Amended by Acts 1988, No. 889, §4 and Acts 1990, No.78, §2, Subpar.(A)(1)(b), effective 1991.

${ }^{338}$ Id. at 56:327.1 et seq.

${ }^{339}$ Id. at 56:360.2.
} 
importation. ${ }^{340}$ To be in compliance for harvest or sale of domesticated aquatic organisms, a potential aquaculture enterprise must also reference Section $413 .{ }^{341}$

The State of Louisiana places great value on riparian property rights associated with aquaculture. Therefore, under Title 9 of the Civil Code, the ability to use water for aquacultural pursuits is outlined. ${ }^{342}$ Similarly, under Chapter 2 of Title 49, the state set forth a coastal zone management program (CZM) in 1978 and later revised under legislative acts in $1989 .{ }^{343}$ CZM provides for permit application for aquaculture activities on CZM lands. ${ }^{344}$ The state considered aquaculture products as property", pursuant to the sport and commercial fishing code under Title 56; this provision was later repealed in $2010 .^{345}$

\section{Maine}

Unlike many states, Maine has a very direct history of aquaculture production listed on the state Department of Marine Resources (Me DMR) website. According to the ME DMR, aquaculture began back in the 1800's, when land was reserved for the culture of shellfish. Public leasing programs began in 1905, which still exist today. The State of Maine endorsed aquaculture as an agriculture pursuit indirectly, by its recognition of the industry in all agriculture related statutes and boards. ${ }^{346}$ Marine aquaculture is mainly enforced by the ME DMR, which began in 1983 (Maine Department of Marine Resources (ME DMR), 2006).

The State has an informative reference site, which can be researched using the internet. Concise links, coupled with updated information, make information dissemination easy for the potential aquaculturist. Individuals interested in verifying compliance with the law can reference

\footnotetext{
${ }^{340}$ Id. at 56:412, et seq.

${ }^{341}$ Id. at 56:413, et seq.

${ }^{342}$ Id. at. 9:1104, et seq.

${ }^{343}$ Id. at 49:214.21.

${ }^{344}$ Id. at 49:214.34 (3).

${ }^{345}$ LSA- R.S. $56: 356$, repealed by acts 2010 , no. 743 , § 2(c).

${ }^{346} 7$ M.R.S.A. $\$ 125(1) \&(2(K)) \&(7)$.
} 
all applicable statutes currently on the books (Maine Department of Marine Resources (ME DMR), 2006). Similarly, any necessary application for permits or leasehold agreements can be accessed from the ME DMR website.

Maine has multiple advisory councils, which manage separate industries to ensure adequate oversight and development. Until being repealed in 2009, the State had an aquaculture advisory council, originally enacted under Title $12 .{ }^{347}$ Likewise, an aquaculture research council was codified under Section 6081, which initially worked concurrently with the main aquaculture advisory council, to pass recommendations and to promulgate rules and regulation for the industry. ${ }^{348}$ A separate shellfish advisory council was promulgated to oversee strictly shellfish culture production. $^{349}$ Since 1995, Maine has been a resource conscious state, which is witnessed by its adoption of a land and water resources council under Title Five Chapter $314 .^{350}$ Following its enactment, the council appointed a member from the state aquaculture industry to hold a public" position on its board. Under a directive from the legislature, the council was to coordinate state policy that would mitigate degradation of the natural environment of the State, by implementing land management programs involving intrastate agency cooperation. This periodic review allowed for a more efficient management of both lands and waters of the state. ${ }^{351}$

The State is progressive with an outreach program creating the Aquaculture Innovations Center, to promote the development of the industry referenced under the Economic and Community Development Code of Title Five, Chapter $387 .{ }^{352}$ Similarly, the state legislature emphasized the importance of aquaculture, by inserting statutes, which promote the State

\footnotetext{
${ }^{347}$ Id. at §12004-I (57-c\&d.)., Original Reference (12 M.R.S.A. $§ 6080$ et seq.)., Repealed by Laws 2009, c. 369, §A.

34812 M.R.S.A. $\$ 6081$ et seq.

${ }^{349}$ Id. at $§ 6038$ et seq.

5 M.R.S.A. $\$ 3331$ et seq.

${ }^{351} \S 3331$, Infra Note 350 at 67.

${ }^{352} 5$ M.R.S.A. §13141(1)(a\&b).
} 
Technology Institute, to focus also on research and development. ${ }^{353}$ Under Title 12, the State created an aquaculture focused management fund, which allows financial access for potential enterprises. ${ }^{354}$ Under Title 7, the State has marketing and labeling provisions set forth under statute to market and promote aquaculture products. ${ }^{355}$ An agriculture marketing loans program, including aquaculture products, has been promulgated also under Title $7 .{ }^{356}$ Similarly in 1999, under the Commerce and Trade code referencing Title 10, the State included aquaculture to be a target area" for economic research and applied development, due to its -significant" benefit to the people and economy of the State. ${ }^{357}$

Marine organism licensure is expressed by Section $6085 .{ }^{358}$ Harvester license exemptions can be referenced under Section 6073C. ${ }^{359}$ Special licensure application must be checked to be in compliance with Section $6071 .^{360}$ A municipal shellfish permit is required for culture. ${ }^{361}$ Atlantic salmon licenses can be purchased pursuant to Section $6140 .{ }^{362}$ Other licenses pertaining to commercialized forms of fishing or aquaculture must be held pursuant to Section $6601 .{ }^{363}$

Under Title 12, any aquaculture enterprise engaged in leasehold must consent to operation inspection. ${ }^{364}$ The State addresses importation of live marine products under statute. ${ }^{365}$ Aquaculture enterprises seeking to import live freshwater fish or eggs must hold a permit

\footnotetext{
${ }^{353}$ Id. at $\S 15301$ et seq.

35412 M.R.S.A. $§ 6072-D$ et seq.

3557 M.R.S.A. $\$ 401$ et seq.

${ }^{356}$ Id. at 434 et seq.

35710 M.R.S.A. $\$ 947$ et seq.

35812 M.R.S.A. $§ 6085$ et seq.

${ }^{359}$ Id. at $§ 6073-c$ et seq.

${ }^{360}$ Id. at $\$ 6074$ et seq.

${ }^{361}$ Id. at $\$ 6673$ et seq.

${ }^{362}$ Id. at $\$ 6140$ et seq.

${ }^{363}$ Id. at $\$ 6601$ et seq.

${ }^{364}$ Id. at 6306 et seq.

${ }^{365}$ Id. at $\$ 6071$ et seq.
} 
pursuant to Section $12509 .{ }^{366}$ Aquatic health provisions are outlined under the state aquaculture monitoring program. ${ }^{367}$ Shellfish health monitoring is regulated separately and referenced also under Title 12. ${ }^{368}$ Antibiotic use notice can be referenced under Section 6078 of the ME DMR code Title $12 .{ }^{369}$ A pathology program was established under Section $6075 .{ }^{370}$

The State has enacted a nutrient management plan for hatcheries, which helps cover waste discharge. ${ }^{371}$ Separate waste discharge classifications invoke the necessity of holding a state discharge license under Chapter 3 of the Protection and Improvement of Waters Code. ${ }^{372}$

A development focused leasing program is outlined under statute. ${ }^{373}$ Also, in 2005, under the Bureau of Parks and Lands code citing Chapter 220, the state legislature inserted an aquaculture exemption with regards to submerged and intertidal lands owned by the State. ${ }^{374}$ Questions into lease options can be referenced under statute. ${ }^{375}$

\section{Maryland}

A statutory reference exists which explains that, in 1987, the State of Maryland was to establish both an aquaculture review board and a coordinating council under state agriculture code. ${ }^{376}$ Undoubtedly, the State saw potential for development of an aquaculture industry. Under Title 10, the Promotion and Identification of Agriculture Products provision outlines authority for seafood marketing under the state Department of Agriculture (MD DOA). ${ }^{377}$ Subtitle 10 designates aquaculture development in accordance with the MD DOA's division of

\footnotetext{
${ }^{366}$ Id. at $\$ 12509$ et seq.

${ }^{367}$ Id. at $\$ 6077$ et seq.

${ }^{368}$ Id. at $\$ 6076$ et seq.

${ }^{369}$ Id. at $\$ 6078$ et seq.

${ }^{370}$ Id. at $\$ 6075$ et seq.

3717 M.R.S.A. $§ 4214$ et seq.

37238 M.R.S.A. $\$ 413$ et seq.

${ }^{373} 12$ M.R.S.A. $§ 6072$ et seq.

${ }^{374}$ Id. at $§ 1862(10)$.

${ }^{375}$ Id. at $\$ 6083$ et seq.

${ }^{376}$ MD Code, Agriculture, §2-106.

${ }^{377}$ MD Code, Agriculture, T. 10, Subt. 10, Refs \& Annos.
} 
marketing development. ${ }^{378}$ The state development act can be referenced under Subtitle 13 of Title 10 of the agriculture code, which was codified in $1988 .{ }^{379}$ The MD DOA as the lead agency under statute. ${ }^{380}$ Unlike other states, Maryland has declared the University of Maryland to be lead research agency, as it pertains to aquaculture production education and extension program implementation. ${ }^{381}$ Though not limited, the state Department of Natural Resources (MD DNR) is responsible for enforcement of laws, regulations and subsequent rules. ${ }^{382}$

Following this declaration, a seafood marketing advisory commission was codified, consisting of 13 members, for industry oversight. ${ }^{383}$ The mission of this advisory commission is two-fold, primarily relating to wild harvest form of aquaculture:

1.) Promoting increased consumption and distribution of Maryland seafood products, and

2.) Seeking out efficient methods to reduce costs, while improving the quality and marketability of Maryland products. ${ }^{384}$

With respect to the aquaculture review board, five members would be chosen to represent the regulatory agencies tasked with management and general oversight. ${ }^{385}$ The MD DOA, the state Department of Environment (MD DOE), the state Department of Health and Mental Hygiene (MD HMH), the state Department of Natural Resources (MD DNR), and a single representative of the state Board of Public Works (MD BPW) would comprise the regulatory side of the board, while an aquaculture coordinator would be elected as the contact person responsible for permit and license application designee. ${ }^{386}$

\footnotetext{
${ }^{378}$ Id. at $\S 10-1001 . \&$ Id. at $\S 10-1301$ et seq.

${ }^{379}$ MD AGRIC $§ 10-1303$.

${ }^{380}$ Id at. $\S 10-1303(c)(1)(2)$. \& Id. at $§ 10-1301(c)$ et seq.

${ }^{381}$ Id. at $\S 10-1301(\mathrm{e})$.

382 Id at. $§ 10-1303(d)$.

383 Id. at §10-1101.

${ }^{384}$ Id at. $\$ 10-1101$ (i)(1)(2).

${ }^{385}$ MD Code, Agriculture, $\S 10-1302$ et seq.

${ }^{386}$ Id. at $\S 10-1302$ ( c)(1)(2).
} 
Separately, the coordinating council would consist of 17 members. ${ }^{387}$ Members include: MD DOA, MD DNR, MD DOE, MD HMH, representatives from the state legislature, and representatives remaining from state higher education institutions and cooperative extension service. ${ }^{388}$ Working in conjunction with the other two boards discussed, the coordinating council acts merely to coordinate research projects, implementing the scientific capacity of higher education, while attempting to streamline the industry.

Separately, under Title 4 of the Fish and Fisheries Code, aquaculture regulation is compiled. $^{389}$ The MD DNR has proposed legislation back in 2002, necessary to ensure that operations do not compromise wild fishery stocks. ${ }^{390}$ This legislation holds MD DNR responsible for working with the aquaculture coordinating council under $\S 4-11 \mathrm{~A}-08$, providing public notice for any amendment to regulation. ${ }^{391}$ Licensure compliance is also required under Subtitle 11A. Following under Section 205.1, nuisance provisions are outlined to comply with Section 11A. ${ }^{392}$ Fishery Management plans, including lists of managed species, is provided under Subtitle 2. ${ }^{393}$ Similarly, under the same code proposal, departmental inspection is now held as a requirement for compliance at reasonable hours for any facility, equipment, and species involved for any permittee in the State. ${ }^{394}$

Oyster culture production has its own set of statutes under Title 4, Subtitle $10 .{ }^{395}$ An oyster shell purchase program has been codified to develop the industry for purposes of the

\footnotetext{
${ }^{387}$ Id. at $§ 10-1303$ et seq.

${ }^{388}$ MD Code, Agriculture, $\S 10-1303(b)$ et seq.

${ }^{389}$ MD NAT RES T. 4 Subt. 11A. et seq.

${ }^{390}$ MD Code, Natural Resources, §4-11A-02(a)(1) et. seq.

${ }^{391}$ Id. at $\S 4-11 \mathrm{~A}-08$.

${ }^{392}$ Id. at $\S 4-205.1(b)(1) \&(2)$ et seq.

${ }^{393}$ Id. at 4-215 et seq.

${ }^{394}$ MD Code, Natural Resources, §4-11A-02(C)(d).

${ }^{395}$ Id. at §4-1019.2 et seq.
} 
product of lime, chicken meal, or road construction projects. ${ }^{396}$ Management plans have begun to be outlined under Subtitle 11 of Title 4 for this species. ${ }^{397}$ Separate endangered species are outlined under statute. ${ }^{398}$ Shellfish importation regulation is outlined under also under Title $4 .{ }^{399}$ Transport regulation for oysters and other mollusks are outlined under Section 18 of Title $4 .^{400}$

State environmental code under Title 5 outlines aquaculture production occurring nearing non-tidal wetlands. ${ }^{401}$ With regard to dredge or fill licensure, aquaculture operations must also comply with licenses obtained by the MD DNR under Title Four, Subtitle 11A. ${ }^{402}$ Aquaculture Enterprise Zones are outlined under the same code to promote production subject to a prior approval by a leasing program for submerged lands with the MD DOE and state Wetlands Administrator of the State Board of Public Works. ${ }^{403}$

The state's economic development division has been tasked with promoting two separate projects affecting aquaculture development. The first program under statute pertains to animal waste technology research, while the second project is a marine processing program. ${ }^{404}$ Under Title 10, a seafood marketing fund was established to allow potential aquaculture enterprises the opportunity to have access to financial capital for operational purposes. ${ }^{405}$ Chesapeake Bay aquaculture is under scrutiny over water quality concerns from other sectors of agriculture. The state legislature placed statutes for production occurring in this region under Title 4, Subtitle $11 \mathrm{~A} .{ }^{406}$

\footnotetext{
${ }^{396}$ Id. at $\$ 4-1909.2$ et seq.

${ }^{397}$ Id. at $§ 4-1103$ et seq.

${ }^{398}$ Id. at $§ 4-2 A-05$ et seq.

${ }^{399}$ Id at $\S 4-11 A-12(b)(1)(2)$ et seq.

${ }^{400}$ Id. at $\S 4-11 \mathrm{~A}-18$ et seq.

${ }^{401}$ MD Code, Environment, §5-901(b)(1).

${ }^{402}$ Id. at $\S 16-202(h)(5)$ et seq.

${ }^{403}$ Nat Resource Aquaculture Code, Infra note 333 at 31.

${ }^{404}$ MD Code, Economic Development, § 5-301 (a)(b)(c).

${ }^{405}$ MD Code, Agriculture, $\$ 10-1002$ et seq.

${ }^{406}$ MD NAT RES T. 4, Subt. 11A $§ 05$ et seq.
} 


\section{Massachusetts}

In 1995, the State of Massachusetts vested interest in aquaculture development. A strategic plan was formally drafted by an advisory committee with no revision to date (Massachusetts Office of Coastal Zone Management (MA CZM), 1995). Today, in the absence of a committee, the state Aquaculture Association (MA AA) (Massachusetts Aquaculture Association (MA AA), 2006) acts as the formal industry governing body that oversees the industry (Massachusetts Aquaculture Association (MA AA), 2006). Following implementation of the state strategic plan, governing bodies, such as the state Department of Agriculture (MA DOA) and state Department of Marine Fisheries (MA DMF), were left to promulgate regulation to ensure that the plan's goals were met. ${ }^{407}$

Under the MA DMF, regulations outlining marine aquaculture management can be referenced. ${ }^{408}$ Under Title 322 , the State expresses clear intent to establish a procedural based legal framework, for which the marine production sector is to development and operate. The scope of regulation reaches possession, transport, and marketing sales of tive" marine organisms. ${ }^{409}$ Anti-degradation measures are briefly mentioned under this procedural development mandate.

License requirements for the state shellfish industry are set forth under Chapter 130 since 1994. ${ }^{410}$ Pursuant to Section 57, all licensees must comply with an annual reporting requirement or forfeiture may occur. ${ }^{411}$ To help alleviate potential development constraints, lobby against

\footnotetext{
${ }^{407}$ Telephone Conference, Sean Bowen, July 2010.,

${ }^{408} 322$ MA ADC 15.01. : (Mass. Regs. Code Tit. 322 §15.01).

${ }^{409}$ Id. at $\$ 15.01$.

${ }^{410}$ M.G.L.A. $130 \S 57$ et seq.

${ }^{411}$ Id. at $130 \S 65$ et seq.
} 
zoning regulations, which normally discourage aquaculture industry growth, resulted in legislation codified under Title 7, Chapter $40 .{ }^{412}$

\section{Michigan}

In 1996, the State of Michigan codified its aquaculture development act (Act 199), which can be referenced under Chapter 286 of the state Agriculture Industry code. ${ }^{413}$ Under Act 199, the state Department of Agriculture (MI DOA) assumes the task as lead agency. ${ }^{414}$ Interesting to note, aquaculture is agriculture" in the State, according to Section 286.874 of Act $199 .{ }^{415}$ Michigan has enacted an approved species list for the industry, which is contained in Act 199. Given the language of the Act, only species listed are allowed to be cultured. ${ }^{416}$ Permitting and registration provisions are outlined under Section $286.876 .^{417}$ Inspection requirements of aquaculture facilities and operations are also outlined under Act $199 .^{418}$

While the State has an approved species list, it also approves research for \#napproved" species pursuant to Act 199. ${ }^{419}$ Prior to the promulgation of Act 199, the State codified the Michigan Animal Industries Act (Act 466) in 1989 under Chapter 287. ${ }^{420}$ Under Act 466, the State was responsible for the prevention, control, and eradication of infectious, contagious, or toxicological diseases that may potentially affect all sectors of agriculture. Act 466 references aquaculture products and aquaculture facilities to ultimately revert back to Chapter $286 .{ }^{421}$

\footnotetext{
${ }^{412}$ M.G.L.A. 40A §3.

413 M.C.L.A. Ch.286 et seq., Michigan Aquaculture Development Act 199. (1996).

${ }^{414}$ Id. at $\$ 286.872(\mathrm{j})$.

${ }^{415}$ Id. at $\$ 286.874(2)$.

${ }^{416}$ Id. at $\$ 286.875$ et seq.

${ }^{417}$ Id. at $\$ 286.876$ et seq.

${ }^{418} \mathrm{Id}$. at $\$ 286.879$ et seq.

${ }^{419}$ Id. at $\$ 286.878$ et seq.

${ }^{420}$ M.C.L.A. Ch.287 et seq., Michigan Animal Industries Act 466 (1989).

${ }^{421}$ Id. at $§ 287.703(4),(5)$.
} 
As in Act 199, the MI DOA is the lead agency for control and oversight of Act $466 .^{422}$ Under Act 466, a state veterinarian is appointed as -ehief animal health official of the state." ${ }^{423}$ The powers of the state veterinarian are outlined under Section 287.708 of the act. ${ }^{424}$ Based on the language of Act 466 in 1994, fish disease inspection reports for aquaculture are mandatory for all products imported into the state. ${ }^{425}$ Following amendments from 1996, more stringent importation requirements are outlined under Section 287.729a for aquaculture in Michigan. ${ }^{426}$ Transgenic or nonnative species culture must comply with requirements under Article Three, Chapter 2 of the state Natural Resources and Environmental Protection Act. ${ }^{427}$

The propagation, rearing, possession, or sale of game fish must occur pursuant to registration and permit requirements under Act 199, according to statutes referenced in Chapter 324. In Michigan, this reference is better known as Act 451 by the state Department of Natural Resources (MI DNR). ${ }^{428}$ Also under Act 451, aquaculture products including fish, reptiles, amphibians, mollusks, crustaceans, or other cultured species are not considered property of the state if the species are propagated, reared, produced, or possessed compliant to requirements of Act 199. ${ }^{429}$ To alleviate permit application constraint, pursuant to Act 199, a game fish breeder's license normally required to be obtained fulfills the same aquaculture permit requirement. ${ }^{430}$ This significance reduces that duplicity normally stifling the aquaculture industry as a whole.

\footnotetext{
${ }^{422}$ Id. at $\S 287.703(14)$.

${ }^{423}$ Id. at $\$ 287.707(1)$.

${ }^{424}$ Id. at $\$ 287.708$ et seq.

${ }^{425}$ Id. at $\$ 287.719(f)$.

${ }^{426}$ Id. at $\left.\$ 287.729 a(1),(2), 3\right)$.

${ }^{427}$ M.C.L.A. $\$ 324.413$ et seq.

${ }^{428}$ Id. at $§ 324.45902(1)(b)$.

${ }^{429}$ Id. at $\S 324.48702(2)$.

${ }^{430}$ Id. at $\S 324.48702(3)$.
} 


\section{Minnesota}

In 1991, the State of Minnesota codified legislation intended to develop aquaculture as a means of -eulturing products for both consumption and sale". ${ }^{431}$ Referencing Chapter 309, sections 4-16 have become known as the state aquaculture development act. ${ }^{432}$ The state Department of Agriculture (MN DOA) has assumed the role of lead agency under statute. ${ }^{433}$ The State has declared aquaculture to be an agricultural pursuit under statute. ${ }^{434}$ More specifically, the act mandates coordination and development under the direction of the Commissioner of Agriculture, as that position was responsible for oversight of the industry and state aquaculture advisory board until recent legislation repealed the advisory committee under statute. In the absence of a committee, the Minnesota Aquaculture Association has been created to oversee potential constraints and address current issues facing the state industry.

In 1994, the State enacted waste disposal legislation for the industry under Section 17.4999. ${ }^{435}$ Minnesota follows NPDES requirements under EPA. Currently, two commercial operations are held to apply for discharge permits. ${ }^{436}$ In its entirety, Minnesota aquaculture exists as small production operations focused on recreational restocking of game fish. Similarly, two farms operate to produce Tilapia sought for table fare. The State has recently proposed legislation to amend permit requirements under statute. ${ }^{437}$ The amendment now reclassifies application for permits under two categories, either private or public, holding the applicant responsible for submitting biographical data for more efficient record keeping of the state industry. Agency coordination, however, is still mandated for both the MN DOA and the state

\footnotetext{
${ }^{431}$ MN ST. $\$ 17.47$.

432 Id. at $\$ 17.46$ et seq., Minnesota Aquaculture Development Act. (1991).

${ }^{433} \mathrm{Id}$. at $\$ 17.47$. (Subdivision Note 6.).

${ }^{434}$ Id. at $\$ 17.49$ et seq.

435 M.S.A. $\$ 17.4999$ et seq.

${ }^{436}$ David Weinand, Telephone Conference (July, 2010).

${ }^{437}$ M.S.A. §13.643. (Subdivision Amendments.3. - §17.47-17.498).
} 
Department of Natural Resources (MN DNR). ${ }^{438}$ Also, under Section 17.494, state permitting is outlined. $^{439}$

Aquatic animal health management in the State follows the USDA APHIS requirements, for the simple fact that creation of a separate state-primacy program would be burdensome financially. Therefore, federal compliance is equally as effective and referenced under statute in the act. $^{440}$ Additionally, inspection process requirements for compliance are outlined. ${ }^{441}$ Minnesota has outlined quarantine provisions under its development act. ${ }^{442}$ The rules for importation of exotic species (i.e. non-native) can be referenced under statute as well. ${ }^{443}$ Likewise, transportation of aquatic life must be reviewed to ensure compliance with Section $17.4985 .^{444}$ If an individual does not hold an aquaculture license pursuant to Section 17.4985, transportation of live fish is prohibited. ${ }^{445}$

The State can be considered environmentally conscious based on the language of its aquaculture development act, referencing Section 17.4981, which outlines the regulation of aquatic farms. This statute considers environmental concerns for aquatic culture decision making. ${ }^{446}$ Aquatic farm licensure must be obtained prior to culture. ${ }^{447}$ Minnesota's aquatic approved species lists can be referenced by researching Chapter $97 \mathrm{~A}-\mathrm{C}^{448}$ To reiterate the notion that the state is environmentally friendly, Minnesota places much emphasis on wetlands

\footnotetext{
${ }^{438}$ MN ST. $\$ 17.47$ (M.S.A. 117.494$)$.

${ }^{439}$ Id. at $\$ 17.494$ et seq.

440 Id. at $\$ 17.4986$.

${ }^{441}$ Id. at $\$ 17.4988$.

442 Id. at $\$ 17.496$ et seq.

${ }^{443}$ Id. at $\S 17.497$ et seq. \& Id. at $§ 17.4986$ et seq.

${ }^{444}$ Id. at $\$ 17.4985$ et seq.

${ }^{445}$ M.S.A. §97C.205(a)(1).

${ }^{446}$ Id. at $§ 17.4981$ et seq.

${ }^{447}$ Id. at $\$ 17.4981$, Subdivision 1, Licensure.

${ }^{448}$ Id. at $§ 17.4984$, Subdivision 3. Listed Species.
} 
protection with regard to aquaculture production. ${ }^{449}$ Aquaculture is provided an exemption under Chapter 103G for wetlands mitigation replacement plans on a conditional basis that pond construction or excavation occurs with notice to the U.S. Army Corps of Engineers. ${ }^{450}$

It is ironic that, for such a small producing state, a comprehensive development act such as this exists. Traditional views of aquacultural development lends that a fully established regulatory act suggests a industry operating at its maximum potential, which is not the case in this state. Besides the normal provisions declaring intentions for promotion and development, the state has sufficiently outlined permit requirements and compliance standards succinctly in a manner suggesting a very efficient industry. But a telephone conversation with industry contacts suggested that the State, as a whole, is a difficult arena to produce. Overall, trend wise Minnesota saw a spike in production in the late 1980's, but production has either slowly dropped off or leveled out in the 1990's to its current level, largely hypothesized on the stringent interstate regulation on market transported products.

\section{Mississippi}

Named for the Mississippi River which forms its western boundary and empties into the Gulf of Mexico, the state of Mississippi is not only steeped in history, but it is also the single largest aquaculture producing state in the U. S. According to the Union of Concerned Scientists, a non-profit group of scientists and environmental lobbyists, the State of Mississippi's aquaculture production value in 2009 was greater than $\$ 290$ million. U.S. Data taken from the Mississippi Department of Agriculture \& Commerce (MS DOA) website suggests that agriculture is the state's leading industry, which employs over $30 \%$ of its total workforce (Mississippi Department of Agriculture and Commerce (MS DOA)). What makes Mississippi

\footnotetext{
${ }^{449}$ M.S.A. §103B.3355(a)(5).

${ }^{450}$ Id. at $\S 103 G .2241(5)$.
} 
such a unique production environment is simply explained by its location to both the fertile Gulf of Mexico and also the Mississippi River Basin. In terms of aquaculture production, the State leads in the following species categories: food fish, baitfish, crawfish, and oysters (Union of Concerned Scientists: Citizens and Scientists for Environmental Solutions, 2010). Catfish in Mississippi is - king

As a state, Mississippi presents a business-friendly environment. Inquiry into their aquaculture industry can be easily accessed through the MS DOA website (Mississippi Department of Agriculture and Commerce (MS DOA)). Mississippi, as an aquaculture producing state, has become quite a diverse economy since the development and implementation of its Aquaculture Act in $1988 .^{451}$

In fact, the Mississippi Aquaculture Act of 1988 enacted the Mississippi Aquaculture Task Force (MS ATF), which consists of a group of state regulatory agencies that possess a shared common interest in aquacultural production, jointly-tasked with oversight and consultation of the state industry. Some of the state agencies involved with the MS ATF include: the Mississippi Department of Agriculture and Commerce (MS DOA), the Mississippi Department of Wildlife, Fisheries and Parks (MS DWF), the Mississippi Department of Marine Resources (MS DMR), Mississippi State University (MSU), the Mississippi Agribusiness Council (MAC), the Gulf Coast Research Laboratory (GCRL), and other aquaculture industry leaders. It is important to note that the MS DOA is charged as lead agency under the Aquaculture Act of 1988 as referenced under Mississippi Code Annotated. ${ }^{452}$ Furthermore, the MS DOA employs an aquaculture coordinator.

\footnotetext{
${ }^{451}$ MS ST. §79-22 et seq. Mississippi Aquaculture Development Act, 1988. ${ }^{452}$ Id. at 79-22-2 (et seq).
} 
Marketing permits for state aquaculture is referenced under code. ${ }^{453}$ Brood stock rules and regulation for the industry is also referenced under the MS ADA. ${ }^{454}$ Tilapia production is protected by regulation enacted under the act. ${ }^{455}$

Continuing to evaluate the MS ADA, a key provision is noticed referencing Section 7922-23, which sets forth a leasing program for state waters, otherwise a general leasing program promoting aquaculture management of natural resources. ${ }^{456}$ Similarly, the state legislature enacted legislation establishing a water leasing program pursuant to Section $79-22-23{ }^{457}$ Mississippi has been declared a progressive development state with its implementation of a - - nestop permit system" under its development act. ${ }^{458}$

A major provision of the state permitting structure reads as follows,

(2) All state and governmental entities that are involved in the regulation and enforcement of marine aquaculture activities or related activities shall develop a coordinated procedure for one-stop permitting applicable to marine aquaculture activities. One-stop permitting is defined as a procedure that allows an aquaculturist to fill out a joint application form and deposit it with any of the aforementioned governmental agencies. The receiving agency shall forward the joint application or copies of it to the appropriate entities for review and expeditious action. The one-stop permitting procedure document shall state the time schedules for review and action by the applicable agencies after the permit has been received and dated.

Mississippi has enacted legislation separately to promote its catfish industry which predates the state aquaculture development act in $1988 .^{459}$ The 1975 law recognized the significance of the market for catfish production in the State; this law also predates the federal 1980 Act. $^{460}$ The Mississippi catfish law originally mandated the MS DOA to act as lead

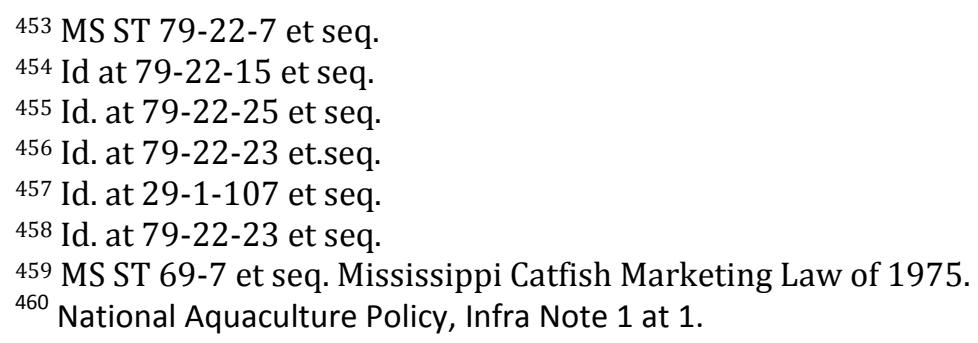


agency. ${ }^{461}$ Rules and regulation pertaining solely to catfish can be referenced under Section 697-611. ${ }^{462}$ Prior certification and disease testing was mandated way before the federal acknowledgment of aquaculture in the U.S. ${ }^{463}$

As in most states, in order to comply with federal guideline set forth under the 1979 CWA, aquaculturists are required to apply for an NPDES permit filed with the Mississippi Department of Environmental Quality Office of Pollution Control located in Jackson. Also, potential operations must obtain a permit with the Mississippi Valley Division of the U.S. Army Corps of Engineers (MVD-USAC), if their operations involve utilization of navigable waters or the disposal of dredge. Permits required for the marketing of cultivated products or aqua cultural activities are to be obtained through the MDAC. Game fish and brood stock harvesting permits were regulated by the MS DWF prior to the 1988 Act.

Additional research was conducted which provides the state of Mississippi has administrative rules for aquaculture. Under Title 22, the MS DMR is to regulate marine aquaculture. ${ }^{464}$ Chapter 4 applies to general aquaculture regulation; while chapter 5 is specific rules for fin fish and crustacean culture production. ${ }^{465}$ Chapter 6 mandates regulation by MS DMR for state mollusk production; while Chapter 7 tasks the MS DMR with industry monitoring. ${ }^{466}$

\footnotetext{
${ }^{461} \mathrm{Id}$. at 69-7-605(e) et seq.

${ }^{462}$ Id. at 69-7-611 et seq.

${ }^{463}$ Id. at 69-7-612 et seq.

${ }^{464}$ MISS. ADMIN. CODE Title 22, Marine Aquaculture Rules \& Regulation.

${ }^{465}$ Id. at Title 22 , ch. 4 et seq. $\&$ ch. 5 et seq.

466 Id. at Title 22 , ch. 6 \& ch. 7 et seq.
} 


\section{Missouri}

In 1989, under Chapter 275, the State of Missouri promulgated its aquaculture marketing council. $^{467}$ The council is tasked with reporting accurate lists of commercial producers of fish products for the State to the state Department of Agriculture (MO DOA). The council's main goal is to enhance the marketability of Missouri aquaculture products. ${ }^{468}$ The council has been delegated authority by the MO DOA to divide the State into aquaculture districts, so representatives from each respective district will be appointed to the council. Under Section 275.454, an aquaculture market fund is authorized and regulated by the state marketing council. Pursuant to the marketing fund, mandatory fees are to be collected from state aquaculture enterprises, which are separate from the normal state licensure or permitting requirements. ${ }^{469}$ The collected funds ensure the MO DOA can market the products.

Aquaculture products are classified as Hivestock" under Chapter 277 of the state Livestock Marketing Law, since $1995 .{ }^{470}$ Missouri has promulgated waste discharge legislation under Chapter 644 to comply with federal permits requirements under the Clean Water Act of $1977 .^{471}$ Aquaculture waste discharge permit questions can be addressed by referencing Section 644.951(4). ${ }^{472}$ Normally, general permits are issued to potential aquaculture operations, but sitespecific permits are also available to be obtained. ${ }^{473}$

\section{Nebraska}

In Nebraska, the state agricultural products marketing act outlined under Article 28 from Chapter 2 designates aquaculture production to fall under the agricultural products"

\footnotetext{
${ }^{467}$ MO ST 275.450 et seq. \& V.A.M.S. 275.450 et seq.

468 Id. at 275.450(5).

${ }^{469}$ Id. at 275.454 et seq.

${ }^{470}$ Id. at 277.024(2)., (L.1995, S.B. No. 109, §A(§1).)

${ }^{471}$ Id. at 644.016 et seq.

472 Id. at 644.051(4).

${ }^{473}$ Id. at 644.051(9).
} 
classification. ${ }^{474}$ More specifically, Section 2-3804.01 declares aquaculture to be construed as agriculture. ${ }^{475}$ In 1987 under Section 2-3815, the state Department of Agriculture (NB DOA) was urged to establish a promotion and development program, which focuses primarily on agriculture-based production such as aquaculture. ${ }^{476}$ This cause for development was amended recently in 2011. ${ }^{477}$ The state development act is referenced under Article 50 following promulgation in $1993 .{ }^{478}$ In conjunction with the codification of the act, the State placed emphasis under the fish and game statutes for the creation of an aquaculture board, repealing the following sections: $37-719,101,102$, and 702 collectively. ${ }^{479}$ The legislative findings of the aquaculture review conducted in 1993 state:

- The Legislature finds that it is in the interest of the people of the state that the practice of aquaculture be encouraged in order to promote agricultural diversification, augment food supplies, expand employment opportunities, promote economic activity, increase stocks of fish, and other aquatic life, protect and better use and manage the natural resource of the state and provide other tangible benefits to the state. ${ }^{480}$

The Nebraska aquaculture board called for an aquaculturist position to be created, which in essence, is the coordinator for industry development and monitoring. ${ }^{481}$ The position is to be employed through the state Cooperative Extension Service pursuant to section 85-1, 104.01. The remaining six board members are appointed under the governor with appointments staggered. ${ }^{482}$ Proposed legislation is the main focus goal for the board to implement. Areas of interests are not limited to the following: funding, production standards for all aquatic-based products, permit structuring, quarantine measures for situations affecting aquatic animal health protocols, penal

\footnotetext{
${ }^{474}$ Neb. Rev. ST. §2-3804.

${ }^{475}$ Id. at $\$ 2-3804.01$ et seq.

${ }^{476}$ Id. at $\$ 2-38185$

${ }^{477}$ Revised Statutory Amendment under 2011 Nebraska Law, L.B. 334.

${ }^{478}$ Neb. Rev. St. §2-5001.

${ }^{479}$ NE LEGIS 830 (1993). (1993 Nebraska Law, L.B. 830).

${ }^{480}$ Id. at Section 1 Findings.

${ }^{481}$ NE ST §2-5003 et seq.

${ }^{482}$ Id. at $§ 2-5003$.
} 
violations for non-compliance, etc. ${ }^{483}$ Specific duties are outlined under section 2-5006 to include the remaining goals: advisory over industry, public consultation and involvement, manage aquatic pathogen introduction, respectively. ${ }^{484}$

Aquaculture is referenced in Chapter 37 of the Game and Parks Code. ${ }^{485}$ Regulatory provisions regarding aquaculture facilities are referenced under Chapter $37{ }^{486}$ State licensure and permit requirements for aquaculture facilities are found under Section 37-461. ${ }^{487}$ Also under the special permits and licenses section of Article 4, reporting by the permit/license holder is mandated to include total number and species cultured, sold, or transported during the year. ${ }^{488}$ Notice is posted by the legislature, pursuant to Section 37-471, which expresses that aquaculture products propagated or raised under a state issued permit may be sold or transported at any time, but subject to rules and regulations adopted, amended, and promulgated by the state Game and Parks Commission. ${ }^{489}$

Furthermore, aquaculture product quarantine measures are outlined under the same code. ${ }^{490}$ Compliance with mandatory facility inspections must occur or permit revocation will result. ${ }^{491}$ Non-resident permit requirements are outlined under the control of the Game and Park Commission as well. ${ }^{492}$

Traditionally, trout has been the main species cultured within the State. For the few commercialized operations, NPDES permits are sought; while the remaining small privatized production operations fall under the necessary permit trigger for application. Most production

\footnotetext{
${ }^{483}$ Id. at $§ 2-5005$.

${ }^{484}$ Id. at $\S 2-5006$.

${ }^{485}$ Id. at $\S 37-203$ et seq.

${ }^{486}$ Id. at $\$ 37-204$ et seq.

${ }^{487}$ Id. at $\$ 37-461$ et seq.

${ }^{488}$ Id. at $\$ 37-469$ et seq.

${ }^{489}$ Id. at $\$ 37-471$ et seq.

${ }^{490}$ Id. at $\$ 37-470$ et seq.

${ }^{491}$ Id. at $§ 37-479$ et seq.

${ }^{492}$ Id. at $\S 37-4,106$ et seq.
} 
occurs for recreational restocking purposes for sport fishing. Though, there is a small production market for food fish culture within the state. The economic feasibility of transporting products across state lines is compromised by tedious costly regulation.

A telephone conversation with the NASAC contact, Steve Martin, revealed that production has the capacity to expand, in lieu of the absent thriving food fish market within state boundaries. At this point, the trend in recreational production is based on the notion that people are spending more on catching fish than eating the product. Mr. Martin indicated that the focus of agricultural development is in other sectors such as cattle, where Nebraska traditionally has been considered a beef state". Martin also noted that the lack of a readily available processor increases the costs to producers, a condition found in other states. ${ }^{493}$

\section{New Hampshire}

The State of New Hampshire recognizes aquaculture production to be a form of traditional agriculture. ${ }^{494}$ The State has vested interest in aquaculture by balancing growth while taking into consideration how to accomplish this goal by not degrading the environment. ${ }^{495}$ No formal designation is given to Chapter 211, Section 62, but most of the aquaculture legislation has been placed under this reference; therefore, this serves indirectly as the state aquaculture development act. ${ }^{496}$ Originally codified in 1978 and amended twice in 1992 and 1995, section 211:62-e serves as the best reference for potential aquaculture enterprises seeking questions pertaining to industry entrance. Under this legislation, the state Fish and Game Commission (NH FGC) was to act as lead regulatory agency. ${ }^{497}$

\footnotetext{
${ }^{493}$ Steve Martin, Telephone Conference, June, 2010.

${ }^{494}$ N.H. Rev. Stat. §21:34-a(II)(a)(6).

${ }^{495}$ Id. at §211:62-e (1).

${ }^{496}$ Id. at $\$ 211: 62-e$, et seq., New Hampshire Aquaculture Development Legislation.

${ }^{497}$ Id. at §206:8(1). \& Id. at §211:62-e(II)(a).
} 
Rulemaking and licensure was to be adopted pursuant to RSA 541-A. ${ }^{498}$ Under this designation, all fees, bonding, insurance, inspection, possession, processing, sale, propagation and rearing, harvesting, and transportation of aquatic and marine specimens culture under aquaculture production schemes were to be promulgated. Separately, license requirement exceptions exist for aquaculture enterprises, which can be referenced under Chapter $214 .{ }^{499}$

Part of the state's development program for aquaculture involves participation in the state Healthy Tidal Waters and Shellfish Protection Program, which began in 2006. ${ }^{500}$ This program is an environmental initiative enacted by the legislature to conduct strategic planning through interagency cooperation, which enhances the potential harvest for New Hampshire shellfish culture, while integrating environmental protection standards to maintain the commercial fishery. The sustainable fisheries movement is a major focus of most recent legislation passed within the past decade in New Hampshire. The State acknowledges the benefit that healthy fisheries present to the public economy and state as a whole through employment, tax-base increases, and recreational income.

\section{New Jersey}

In 1997, the State of New Jersey vested interest in aquaculture development. The state aquaculture development act (Act 236) can be referenced under Chapter 27 of the statute. ${ }^{501}$ The state development act was prepared by the state Aquaculture Development Task Force, promulgated under Executive Order No. 104 in 1993. ${ }^{502}$ Pursuant to the act under Section 5, the state Aquaculture Advisory Council was established. ${ }^{503}$ Similarly, in conjunction with the

\footnotetext{
${ }^{498}$ Id. at $\S 211: 62-e(I I)$.

${ }^{499}$ Id. at $\$ 214: 2(1)$.

${ }^{500}$ Id. at $\$ 487: 34($ II) et seq.

${ }^{501}$ NJ ST §4:27-(1-24) et seq., New Jersey Aquaculture Development Act. (1997). Added by L.1997, c.236, §1.

${ }^{502}$ Id. at $\S 4: 27-3$.

${ }^{503}$ Id. at $\S 4: 27-5$.
} 
council, the Office of Aquaculture Coordination was promulgated under Section 4 of the act. ${ }^{504}$ The lead agency was delegated to the state Department of Agriculture (NJ DOA) under statute, where it also declares aquaculture as agriculture. ${ }^{505}$

The state legislature codified an interagency memorandum of agreement by the state Department of Environment Protection (NJ DEP) and NJ DOA. ${ }^{506}$ To be included under the memorandum of agreement is the promotion initiative, promulgated by the state legislature, for an informational campaign to feasibly develop and enhance the marketability of state culture products. ${ }^{507}$ The promotional program delegated to the state advisory council to work concurrently with other state regulatory agencies.

The State had an interesting differing addendum to statute, where provisions for protection of wetlands and sedimentation issues were outlined. ${ }^{508}$ Specific soil erosion measures are later outlined under the state development act with regard to aquaculture production operations to be monitored by the advisory council and the NJ DEP. ${ }^{509}$ Separate statutory provisions may affect aquaculture enterprises concerning water supply. ${ }^{510}$ The State has implemented a water management plan, which may include aquaculture for the diversion from both saline and freshwater groundwater sources. ${ }^{511}$ Water pollution control measures are outlined under Chapter 10A. ${ }^{512}$ Waste discharge limitations for aquaculture enterprises can be

\footnotetext{
${ }^{504}$ Id. at $\S 4: 27-4$.

${ }^{505}$ Id. at $\$ 4: 27-6$ et seq.

${ }^{506}$ Id. at $\$ 4: 27-9$ et seq.

${ }^{507}$ Id. at $\S 4: 27-22$ et seq.

$508 \mathrm{ld}$. at $\$ 4: 27-12,13,16$.

${ }^{509}$ Id. at $\S 4: 27-16$ et seq.

${ }^{510} \mathrm{Id}$. at $§ 58: 1 \mathrm{~A}-3$ et seq.

511 Id. at §58:1A-13(4).

${ }^{512}$ Id. at $§ 58: 10 A-3$ et seq.
} 
referenced also under Chapter 10A. ${ }^{513}$ State waste discharge permits are accessed through both the EPA and NJ DEP. ${ }^{514}$

Like many of the other states, New Jersey set forth mandates for licensure and permitting under statute in its development act. $^{515}$ Also, the state legislature recognized the New Jersey Aquaculture Association under also under Act 236. ${ }^{516}$ The need for aquatic health management was not overlooked by the creators of the development act, for this potential issue was succinctly outlined under 4:27-18. ${ }^{517}$ NJ DEP has been tasked with formulating a comprehensive waste management plan as it would pertain to aquaculture and other agricultural-based industries. ${ }^{518}$

Aquaculture leases are outlined under the state development act ${ }^{519} \mathrm{~A}$ leasing program has been implemented, under the NJ DEP, for development of shellfish culturing utilizing coastal lands under Chapter 25..$^{520}$ Under Chapter 1, Title 50, the state has enacted statutory recognition of its shellfish industry, which dates back to $1996 .^{521}$ An advisory council was promulgated, pursuant to the shellfish code, which is tasked with comprising development policies in conjunction to researching and assisting in the marketing of products for the state economy. ${ }^{522}$ Licensure requirements for shellfish culture are outlined under Chapter $2 .^{523}$ Similarly, the purchase or transportation of oysters or other shellfish is regulated based on statute from Section $50: 2-12 .^{524}$

\footnotetext{
513 Id. at $§ 58: 10 A-6$ et seq.

${ }^{514} \mathrm{Id}$. at $\S 58: 10 \mathrm{~A}-7.1$ et seq.

${ }^{515} \mathrm{Id}$. at $§ 4: 27-10$ et seq.

${ }^{516}$ Id. at §4:1-6 et seq., Added by L.1997, c.236, §25.

${ }^{517}$ Id. at $\$ 4: 27-18$.

${ }^{518}$ Id. at §13:1D-9. (Proposed Legislation, Jan. 2008).

${ }^{519}$ Id. at $\S 4: 27-8$ et seq.

${ }^{520}$ NJ ADC $\S 7: 25-24.1$.

${ }^{521}$ Id. at $§ 50: 1-18(a)$.

522 Id. at $\S 50: 1-18(\mathrm{~b})(\mathrm{d})$.

${ }^{523}$ Id. at $\S 50: 2-2$ et seq.

${ }^{524}$ Id. at $§ 50: 2-12$ et seq.
} 
Back in 1999, the state legislature acknowledged the importance of higher education, represented by Rutgers University, through its fisheries management research. What resulted from this acknowledgment was the promulgation of the state Fisheries Information and Development Center, which was to be under the authority of the Institute of Marine and Coastal Sciences Program at Rutgers University. ${ }^{525}$ In its conservation friendly point of view, Rutgers was tasked with creating a research coordinating program to stimulate the state aquaculture industry, through establishing a commercial fisheries-friendly management program.

Later in 2007 , the state legislature began revising its marine fisheries code, pending the release of research suggesting how aquaculture in other states had been stated to cause environmental degradation, resulting from poor management practices. In a proactive manner, the legislature promulgated the Aquaculture Technology Extension Center to encourage development of the state industry, while integrating protection of natural fisheries and surrounding habitats under Title $23 .^{526}$ Following the implementation of the Aquaculture Technology Center, the state went one step further to revise its original Aquaculture Task Force to conduct a thorough 2-year, re-evaluation of the industry under statutory mandate. ${ }^{527}$ Some of the stated goals declared by the legislature were to promote commercial fisheries, clearly define roles of the state regulatory agencies, and mandate reports directly to both the Governor and Legislature, by way of recommendations to stimulate the industry.

\section{New York}

Taken from 2004 legislation passed, the State of New York acknowledges aquaculture to be an agricultural-based industry, subject to the same access for product marketing. ${ }^{528}$

\footnotetext{
${ }^{525}$ Id. at §18A:65-86 et seq., Added by L.1999, c.419, §1, eff. Jan. 18, 2000.

${ }^{526}$ N.J.S.A. T.23, Ch.2B et seq., New Jersey Marine Fisheries Code.

${ }^{527}$ Id. at $\S 23: 2 B-10$ et seq.

${ }^{528}$ NY AGRI \& MKTS $\$ 293(1-a)$ \& (1-b).
} 
Researching historical background explains that, in 1994, the State endorsed aquaculture originally under Article 13 of the Marine and Coastal Resources code. ${ }^{529}$ Under this original statute designation, the State recognized the potential relief aquaculture presented to economically important species, which in return enhanced natural, viable, wild species stocks.

The State originally enacted freshwater wetlands regulations under Title 7 of Article 24 . Following amendments in the early 1990's, aquaculture permitting was included, where the deposition or removal of the natural products of such environments was deemed regulated. ${ }^{530}$ Similarly, under Title 4, more regulation pertaining to aquaculture occurring in tidal wetland environments is referenced. ${ }^{531}$

\section{North Carolina}

Commercial aquaculture has been practiced in North Carolina, prior to the recent codification of the industry in 1989 with the creation and passage of the North Carolina Aquaculture Development Act (NC ADA). ${ }^{532}$ The NC ADA formally charges the North Carolina Department of Agriculture (NC DOA) as the lead agency and commissioner of its aquaculture advisory board. ${ }^{533}$ The State acknowledges aquaculture as agriculture, which is referenced under the state Agriculture Development code, Chapter 106, Article $52 .{ }^{534}$ The NC ADA is a substantive document that outlines the following: registration and licensing, aquatic animal health, watercourse information, and penalty violations, all under one article of state

\footnotetext{
${ }^{529}$ NY ENVIR CONSER §13-0105(7).

${ }^{530}$ Id. at $\S 24-0701(3)$.

${ }^{531}$ Id. at $\S 25-0401(3)$.

${ }^{532}$ G.S. 113-129, \& NC ST §106 et seq., North Carolina Aquaculture Development Act.

${ }^{533}$ Id. at $\$ 106-759$ et seq.

${ }^{534}$ Id. at $\S 106-581.1(4)$.
} 
code. Under the state development act, an aquaculture focused advisory board was established within the NC DOA. ${ }^{535}$

Aquaculture facility registration and licensure compliance is outlined under the state development act. ${ }^{536}$ Approved species listing is referenced under the same section of the act. Aquatic disease management is discussed under Section 106-762. ${ }^{537}$ The sale of fish is regulated under Chapter 113, Article 14A, of the Coast and Estuarine Commercial Fishing Licenses Code $^{538}$

North Carolina promulgated the Joint Legislative Commission on Seafood and Aquaculture in $1989 .{ }^{539}$ One of the main goals was to study and evaluate the effects on water pollution in the state. Also to help stimulate industry growth, the state has enacted a fishery management plan program to include marine aquaculture production. ${ }^{540}$ The State promulgated a fishery resource grant program, to include higher education, to protect and enhance the state's coastal fisheries by providing research grants for aquaculture (both freshwater and marine production sectors). ${ }^{541}$ Since 1997, the commission reports annually on the state codified coastal habitat protection plan, which includes aquaculture production. ${ }^{542}$

Following the passage of the state development act, a non-profit group was created in 1991 under the name of The North Carolina Aquaculture Association, consisting of state regulatory agencies, producers, and higher education. The association's main goal is aimed at providing support through promotion, marketing, and other beneficial acts to strengthen, expand,

\footnotetext{
${ }^{535}$ Id. at $§ 106-760$ et seq.

${ }^{536}$ Id. at $\$ 106-761$

${ }^{537}$ Id. at $§ 106-762$ et seq.

${ }^{538}$ Id. at $\S 113-168.4$ (b) et seq.

${ }^{539}$ Id. at $\$ 120-70.60$ et seq., Laws 1989, c. $802, \S 12.1$.

${ }^{540}$ Id. at $§ 113-182.1$ (c1-e) et seq.

${ }^{541}$ Id. at $\$ 113-200(a)(3)$, (b), (i) et seq.

${ }^{542}$ Id. at $\S 143 B-279.8$ et seq.
} 
and diversify the industries of freshwater and marine aquaculture in the State of North Carolina (North Carolina Aquaculture Association (NC AA)).

Currently, the NC DOA employs two aquaculture coordinators that are responsible for both the eastern and western parts of the state. They are responsible for acting as an intermediary between the regulatory components enforced by state agencies and the public sector, including higher education and the industry producers. Also, contained within NC DOA is a reputable marketing department, which strongly endorses this state agricultural industry as An Aquaculture Friendly State. ${ }^{, 543}$

The North Carolina aquaculture industry currently focuses on the following species: trout, catfish, hybrid striped bass, crawfish, ornamental fish, baitfish, clams, and oysters, according to the NC DOA website (North Carolina Department of Agriculture \& Consumer Services (NC DOA)). From data released by the NC DOA, it is suggested that in 2001, North Carolina was the second largest producer of trout (10\% of total production in the U.S.) behind Idaho (58\%). The value of production in 2001 for trout alone brought approximately $\$ 6.4$ million, based on data reporting that a total of $\$ 64$ million dollars worth of trout were produced in the U.S. ${ }^{544}$

Shellfish culture in the state has a leasing program available for residents, which helps promote the industry. ${ }^{545}$ Pursuant to Section 113-202, the State of North Carolina also permits water column leasing to apply to aquaculture enterprises, for development of its shellfish culture program. ${ }^{546}$ The state legislature has declared the transportation of specific shellfish (i.e. oysters

\footnotetext{
${ }^{543}$ Telephone Conference, Debra Sloan, May, 2010.

544 Sloan, Infra Note 543 at 92.

${ }^{545}$ N.C.G.S.A $\S 113-202$ et seq.

${ }^{546}$ Id. at $\$ 113-202.1(b)(1-4) \&(c)(4-5) \&(i)$ et seq.
} 
and clams) to be lawful under a slot size limit, which can be referenced under Article 16 of Chapter $113^{547}$

North Carolina's freshwater production capacity is unique. For instance, the westernmost region of the state utilizes cool and coldwater flow-through, raceway and tank culture production systems. On the other hand, production occurs in the middle region of the State, utilizing primarily recirculation tank systems that are water-limiting, to conserve the resource for domestic usage. Lastly, aquaculture production occurring in the eastern-most part of the state is primarily dominated by warm water pond production. The State has overcome constraints with water availability by adapting specialized production schemes to match each unique production environment.

As a result of appropriate regulation, efforts to strongly endorse the industry on the part of the NC DOA, coupled along with a solid work force, has created a viable industry in North Carolina, which currently produces $\$ 10-50$ million dollars in valued revenue each year. The state's success can also be attributed to the dedication of the individuals responsible for oversight and industry coordination. It is obvious in North Carolina's sense of pride about the industry that most participants recognize the value and future potential of continuing promotion and development of this important resource. As future demand continues to grow for both recreational and commercial fishing for food sources, the availability of aquaculture enterprises in the State will help to satiate this greater demand for sustenance. ${ }^{548}$

${ }^{547}$ Id. at $\$ 113-203$ et seq.

${ }^{548}$ Sloan Infra Note 543 at 92. 


\section{Ohio}

Under Chapter 1, agriculture" has been expanded in Ohio to include aquaculture production. ${ }^{549}$ Applying the agriculture classification, aquaculture appears under Title 3 of the County Code, which discusses agriculture revitalization as a means of repurposing slums or blighted areas. Under this particular designation, aquaculture has been recognized as a beneficial agricultural influenced" industry by which repurposing would occur: this declaration indicates the state's position of importance for this industry. ${ }^{550}$

Title 15 has indirectly become the state aquaculture development code. ${ }^{551}$ The state Division of Wildlife $(\mathrm{OH} \mathrm{DW})$ handles regulation of aquaculture permits. ${ }^{552}$ The adoption of rules and regulation pertaining to aquaculture production in Ohio is handled by the $\mathrm{OH} \mathrm{DW}$. $^{553}$ Under Title 15 of the Conservation of Natural Resource Code outlines permit requirements. ${ }^{554}$ Specifically, transfer permits are to be obtained pursuant to section 1533.301 , which was recently amended under legislative review. ${ }^{555}$

The State has permits under two categories: class A and class B. ${ }^{556}$ Under statute, class A permit application envisions the intent to possess, buy, and sell species, except unrestricted, that are labeled aquacultural products. Class B permits cover restricted or unclassified species listings, that can be referenced under state rule 1501:31-1-02 of the Administrative Code. ${ }^{557}$ Ohio explicitly declares that the sale of aquaculture specimens is deemed unlawful given two conditions. First, the sale is unlawful if specimens were not cultured in a state approved and

\footnotetext{
${ }^{549}$ R.C. $§ 1.61$ (Definition Agriculture Classification).

550 Id. at $§ 303.01$.

551 Id. at $§ 1533.632$ et seq., Ohio Aquaculture Code.

552 Id. at $\S 1533.632(\mathrm{~A})(3)$.

553 Id. at $\$ 1533.632$ (B) et seq.

$554 \$ 1533.632$ et seq., Infra Note 551 at 94.

555 Id. at $\$ 1533.40$ (Revised Code)- (Originally, R.C. §1533.301).

${ }^{556} \mathrm{OH}$ ADC 1501:31-39-01(D)(1),(2) et seq.

${ }^{557}$ Id. at 1501:31-39-01(E), F).
} 
registered aquaculture production facility. ${ }^{558}$ Second, sale is unlawful if an individual does not hold a current, valid aquaculture permit. ${ }^{559}$ The State has addressed disparagement concerns, similar to Louisiana, by enacting regulation under the state Civil Action Code, Title XXIII. ${ }^{560}$

\section{Oklahoma}

An extensive review of the State of Oklahoma's aquaculture industry returns disappointing results. Originally, the legislature placed aquaculture on the books in 1974, sponsored largely by U. S. Representative Wes Watkins. ${ }^{561}$ Watkins worked to appropriate funds for research for the state's aquaculture development for about a decade in the late 70's and early 80 's. His point of view was that aquaculture would provide a way for the state to diversify its economy. But funding for this research dried up; and progress in this area was halted. Nearly three decades later, the state industry is still in the beginning phase of development. Originally, the State had codified legislation for aquaculture relating to licensure, technical assistance, and wild species inspection and reporting mandates, all of which have since been repealed. ${ }^{562}$

In the early 2000s, the State developed an Aquatic Strategic Plan," which outlines the creation of an advisory council to oversee the development of the industry. In the absence of formal codification, a group of individuals led both by current producers and regulatory officials meet on an informal basis to oversee the minimal amount of production. ${ }^{563}$

The State has a minimal license requirement, following the repeal of major legislation in 2002. However, what still can be referenced under Chapter 1, Article 6, outlines a requirement

\footnotetext{
${ }^{558}$ R.C. $§ 1533.632(\mathrm{C})$

${ }^{559}$ Id. at $\S 1533.632(\mathrm{D})$.

${ }^{560}$ Id. at $\$ 2307.81(\mathrm{~b})(3)$.

56129 Okl.St.Ann. 4-102.

56229 O.S. 2001, Sections, 4-102, 6-101. 6-102, 6-103, 6-104, and 6-105 Repealed by Laws 2002, c. 295.

563 Telephone Conference, Dr. Hall, April 2011.
} 
to hold an OK DOA commercial production license. ${ }^{564}$ Other licensure must be referenced with Chapter 1, Article 4. ${ }^{565}$ Approved species in Oklahoma include catfish, minnows, fingerlings, fish, frogs, etc. Restricted species are based solely on the importation/ exportation requirements for minnows and fish, held to comply with Chapter 1, Article 7 of the wildlife transportation code. ${ }^{566}$ Minnow licenses are pursuant to Chapter 1, Article 4. ${ }^{567}$

With regard to waste water discharge, the State bases enforcement on state-driven BMPs, while federal NPDES requirements still apply. ${ }^{568}$ Because production is minimal, the discharge permit requirements have not yet actually been triggered. ${ }^{569}$ In 2002 , the State addressed waste discharge issues by delegating oversight authority to the state Department of Environmental Quality, (OK DEQ). ${ }^{570}$ Further research reveals that Oklahoma has licensing requirements under statute. $^{571}$ Ultimate environmental jurisdiction over aquaculture and fish hatcheries, however, was delegated following amendment in 2006 to the OK DEQ. ${ }^{572}$

The current production occurring in the State of Oklahoma focuses on recreational fish stocking, being one of the largest producers of seahorses in the country. Production within the State occurs for the following species: baitfish, channel catfish, paddlefish, crawfish, frogs, shrimp, fingerlings, tilapia, trout and salmon. ${ }^{573}$

Dr. Hall's recommendation, during telephonic conference, suggests that, in lieu of Oklahoma's current status, the state would benefit from implementing a centralized processing plant. Hall's belief purports that this notion would reduce operators' processing fees, provide

\footnotetext{
${ }^{564} 2$ Okl.St.Ann. §6-311(A).

${ }^{565} 29$ Okl.St.Ann. §4-105 et seq.

${ }^{566}$ Id. at §6-311(D). \& 29 Okl.St.Ann. §7-602 et seq.

${ }^{567} 29$ Okl.St.Ann. §4-115 et seq.

${ }^{568} 2$ Okl.St.Ann. §2-4(16)(a)(3).

${ }^{569}$ Hall, Infra note 563 at 96.

${ }^{570} 2$ Okl.St.Ann. §3-85(H.1)(c).

${ }^{571}$ Oklahoma Statutes, 35:50-1-30 \& 32 et seq.,

572 Okl.St.Ann. §8-41.16(3) et seq.

573 Hall, Infra note 563 at 96.
} 
stable jobs, raise state revenues, and allow for overall growth of the state aquaculture industry, much like that envisioned by Watkins in the 70 s. ${ }^{574}$

\section{Oregon}

Based on legislation from 2006, Oregon's Fish and Wildlife Commission (OR FWC) is authorized to issue special permits with regard to white sturgeon egg collection for commercial aquaculture. ${ }^{575}$ No further statutes or regulations were found during the legislative review. Multiple attempts to contact the state expert were made but were unsuccessful.

\section{Pennsylvania}

Beginning in 1998, the State of Pennsylvania initiated its aquaculture development law by enacting a series of statutes under Chapter 42 of Title 3, which can be referenced in the state code. ${ }^{576}$ Originally, the state industry was regulated by the state Fish and Boat Commission (PA FBC) until completion of its development act (Faulds \& Conklin, 2009). Section 4202(1) acknowledges that aquaculture operations should be viewed the same as other agriculture sectors and, therefore, should receive the same protections. Under subchapter b of Chapter 42 , the State designates aquaculture as agriculture, a progressive stance towards future development. ${ }^{577}$ As a result of these actions, there was now a vested interest in furthering the state industry for aquaculture production. The State went to the next step through its enactment of Title 7, Chapter 106 , which sets forth the state's formal aquaculture development plan. $^{578}$

\footnotetext{
${ }^{574}$ Hall, Infra note 563 at 96.

575 O.R.S. $\$ 497.325(3)$.

5763 Pa.C.S.A. § 4201, Pennsylvania Aquaculture Development Law, added by 1998, Oct. 16, P.L. 768, No. 94 , § 1.

577 PA ST 3 Pa.C.S.A. §4211: “Aquaculture is hereby designated as a normal farming operation within this Commonwealth for all purposes. This designation shall be recognized by all agencies and local government."

${ }^{578} 7$ Pa.C.S.A § 106.1 et seq.
} 
Section 4216 of Chapter 42 sets forth the establishment of Pennsylvania's Aquaculture Advisory Committee (PA AAC) ${ }^{579}$ This board exists within the Department of Agriculture, comprised of a 21 member board, whose participants include the following ex officio members ${ }^{580}$ : the Secretary of Agriculture, the Secretary of Environmental Protection, the Secretary of Community and Economic Development, the Executive Director of the PA Fish and Boat Commission, four members from the state legislative committee for Agriculture and Rural Affairs and four members from the Game and Fisheries Committee, also from the state legislature. Nine additional at-large members are appointed by the Secretary of Agriculture, including aquaculture producers from different sectors of production or suppliers and one appointee representing recreational sport fishing. ${ }^{581}$

The purpose of this committee was to draft and submit the development plan itself, with a focus on economic development, not to exclude recommendations for regulations necessary to promote statewide development of the industry. In its entirety, its advisory component exists to report directly to the Secretary of Agriculture on production and development issues. ${ }^{52}$ The state development law mandated biennial statistical reporting to be conducted to allow accurate record keeping for the state industry. ${ }^{583}$ Similarly, the state legislature enacted an industry development account to financially stimulate growth of the aquacultural community in PA. ${ }^{54}$

Before enactment of the plan, aquaculturists were subjected to a somewhat complex permitting system that existed in the State of Pennsylvania. Under federal mandate by EPA, any

\footnotetext{
${ }^{579}$ Id. at $\S 4216$ et seq.

${ }^{580}$ An ex) (b).

${ }^{580}$ Id. at $\S 4216(d)$.

${ }^{580}$ Id. at $\$ 4217$ et seq.

${ }^{580}$ Id. at $§ 4218$ et seq. officio member is a member of a body (a board, committee, council, etc.) who is part of it by holding another office.

${ }^{581}$ Id. at $\S 4216$ (a) (b).

${ }^{582}$ Id. at $\S 4216$ (d).

${ }^{583}$ Id. at $\S 4217$ et seq.

${ }^{584}$ Id. at $\S 4218$ et seq.
} 
operation is required to apply for a general discharge permit pursuant to Section 402 NPDES. Pennsylvania currently does not have a state driven NPDES program, though for the past decade the state advisory committee has been discussing how to implement waste discharge measures. Beyond that general permit, there is a state application process under the Department of Environmental Protection (PA DEP). ${ }^{585}$ The complexity arose when an upcoming aquaculturist sought to comply with operational requirements and he/she missed one or the other permit. The entire permit would then be denied.

To solve this, the State of Pennsylvania in 2000 began to develop a comprehensive - - ne stop shop" consolidated permit for all potential discharges. This reduces permit application time, streamlining the startup or development process for a potential enterprise. Following in line with its permit restructuring, the State of Pennsylvania also reclassified its aquacultural waste designation. ${ }^{586}$ This reclassification of aquacultural waste to agricultural waste now subjected aquaculture enterprises to less intensive waste disposal practices, which opened up the overall industry requirements.

A telephone conference with the state NASAC contact returned that Pennsylvania addresses aquatic animal health requirements from the U.S.D.A. by mandating a three-phase pathogen testing for the prevention of any virological, parasitological, and bacterial introduction into state waters or interstate transportation to other states. Viral Hemorraghic Septicemia (VHS) was a recent pathogen to affect the state aquaculture industry. Great lakes culture suffered from stifling regulation over stock transportation. VHS came at high costs to producers,

\footnotetext{
${ }^{585} 3$ Pa.C.S.A. § 4213(b).

${ }^{586} 35$ P.S. § 6018.103.
} 
considering additional certification testing was required. Pennsylvania production has consequently suffered from this event. ${ }^{587}$

Recently published by the North Eastern Regional Aquaculture Center (NRAC) was the outlook for the state, taken from data released in 2008 and 2009. The report suggests that the State saw trout sales valued at $\$ 10.48$ million dollars. The food fish sector comprised the largest production totals at $83.4 \%$. Data was also released for hatchery production, which when totaled, valued approximately $\$ 20.12$ million dollars of product for the state in 2008 alone (Faulds \& Conklin, 2009). Also contained in the report is a section mentioning the following constraints or issues presently faced by the state industry elaborated as the following points:

1.) Development of more effective and uniform regional policies and management techniques dealing with interstate regulations on fish health and biosecurity,

2.) Providing assistance in bringing the industry into compliance with National Pollution Discharge Elimination System (NPDES) permits, with minimal financial impacts on farmers,

3.) Providing clear messages and balanced public awareness of the risks and benefits of consuming farmed fish (Public Information Dissemination),

4.) Establishment of a comprehensive PA fish pathogen laboratory that can test for viral, bacterial, and parasitic diseases (Faulds \& Conklin, 2009).

\section{Rhode Island}

Since 1982, aquaculture has been referenced in Rhode Island as an agricultural operation under state code. ${ }^{588}$ Early on, the State addressed possessory issues over aquaculture products to fall under Title 20 of the state Fish and Wildlife code. ${ }^{589}$ In 2001, the State acknowledged the implementation of an aquaculture coordinator, which can be referenced under Chapter 2 of the Fish and Wildlife code. ${ }^{590}$ Apparently, under the same legislative session, a distinction was made between commercial fishing and commercial aquaculture, due to the language of Section

\footnotetext{
${ }^{587}$ Telephone Conference, Charlie Conklin, June, 2011.

588 Gen. Laws 1956, §2-23-4(a).

589 Id. at $\$ 20-1-3(6)$.

590 Id. at $§ 20-2-45(c)$.
} 
20-3.1-7(4), which can be referenced under the state Marine Fisheries Management Modernization legislation, also in $2001 .{ }^{591}$ In 2002, the State recognized the assistance of higher education by naming the Blount Aquaculture Research Facility."

Aquaculture in Rhode Island can be referenced under chapter $10 .{ }^{593}$ The State was tasked with enacting a biosecurity board under statute. ${ }^{594}$ This seven member state board was to operate under the Coastal Resources Management Council (CRMC) to advise on aquatic diseases, while preventing pathogen introduction, which may potentially contaminate the state waters and aquatic life. The CRMC was codified under Title $46 .{ }^{595}$ According to language referenced under Section 20-10-2(3), the state Department of Environment Management (RI DEM) is the lead agency for Rhode Island aquaculture. ${ }^{596}$ Under statute, both the RI DEM and the CRMC are delegated ultimate authority to adopt, repeal, or amend any rules and regulations necessary to aquaculture in Rhode Island. ${ }^{597}$

The CRMC has been delegated authority to issue permits for compliant aquaculture production pursuant to Chapter $10{ }^{598}$ Permit application questions can be addressed by researching Section 20-10-4 et seq. ${ }^{59}$ Permit approval is subject to guidelines also referenced under Chapter $10 .^{600}$ The State offers a lease program to stimulate growth for aquaculture. ${ }^{601}$ Associated fees and restrictions are stated under Chapter 10 as well. ${ }^{602}$ Unlike other states, Rhode Island has a performance bond requirement for permits being applied for by aquaculture

\footnotetext{
${ }^{591}$ Id. at $\S 20-3.1-7(4)$.

592 Id. at $\$ 22-7.4-78$.

593 RI ST.T. 20, Ch.10, Rhode Island Aquaculture Development Legislation.

${ }^{594}$ Id. at $§ 20-10-1.1$ et seq.

${ }^{595} \mathrm{Id}$. at $§ 46-23-1$ et seq.

${ }^{596}$ Id. at $§ 20-10-2(3)$.

${ }^{597}$ Id. at $§ 20-10-11$ et seq.

${ }^{598}$ Id. at $§ 20-10-3$ et seq.

${ }^{599}$ Id. at $§ 20-10-4$ et seq.

${ }^{600} \mathrm{Id}$. at $§ 20-10-5$ et seq.

${ }^{601}$ Id. at $§ 20-10-6$ et seq.

${ }^{602}$ Id. at §20-10-7 \& §20-10-9 et seq.
} 
operations, subject to forfeiture if the permittee is found to violate his or her permit, adversely affecting the environment. ${ }^{603}$ Transportation, importation, sale, or taking permits and other licensure questions can be addressed under Section 20-10-12. ${ }^{604}$ The RI DEM has the right to enter and inspect all areas subject to aquaculture permits held under state mandate. ${ }^{605}$

\section{South Carolina}

Aquaculture's roots in South Carolina are witnessed by the state's declaration that the industry is agriculture under the 1986 revision to Title 46 of the Agriculture Code. ${ }^{606}$ In 1988 , the state legislature promulgated an aquaculture focused permit office with the state Department of Agriculture (SC DOA). ${ }^{607}$ The preamble of Act 586 of 1988 recognizes the SC DOA as the lead agency responsible for coordination and promotion in the state. Furthermore, the SC DOA under Act 587 was tasked with issuing aquaculture permits pursuant to Section 46-51-10. Under Act 587, the state Wildlife and Marine Resources Department (SC WMD) is responsible for fulfilling a law enforcement and research and development position, to work concurrently with the SC DOA. ${ }^{608}$

In 1989, the South Carolina Aquaculture Association (SC AA) was formed with the purpose of conducting activities beneficial to the production, promotion and marketing of aquaculture in South Carolina. This informal move allowed the SC AA to oversee and operate the state industry without the need of funding a formal advisory board. The SC AA is comprised of producers, suppliers, educators, technical support, regulatory agencies, government representatives and interested individuals. A seven member Board of Directors, elected by SC

\footnotetext{
${ }^{603}$ Id. at $\S 20-10-8$ et seq.

604 Id. at $\$ 20-10-12$ et seq.

${ }^{605}$ Id. at $\$ 20-10-15$.

${ }^{606}$ Code 1976, §46-1-10 et seq.

${ }^{607}$ Id. at §46-51-10 et seq.

6081988 Act No. 587, §1, eff. June, 3, 1988.
} 
AA members, was enacted to addresses industry issues and concerns, such as marketing, regulation, education, legislation, technology and research, and lastly, the preservation of the environment.

On a regular basis, the SC AA coordinates with the SC DOA, which is the lead agency responsible for marketing of the industry. Currently, the SC DOA employs one aquaculture coordinator. The role of the SC DOA aquaculture coordinator encompasses a variety of tasks including: marketing and advertising, mediation between regulatory agencies, higher education, and the industry, and also reporting directly to the commissioner of the SC DOA. ${ }^{609}$

Other agency involvement primarily includes the South Carolina Department of Natural Resources (SC DNR), whose responsibility lies in permitting of the industry. Mariculture is the sector that the SC DNR most actively regulated. However, the SC DNR does oversee a collection of state fish hatcheries to augment recreational stocks.

The organization of the South Carolina Aquaculture code is convoluted at best. Outlining the history of the state industry stretches for almost two decades before the state aquaculture enabling act (SC AEA) under Chapter 18 was promulgated in $2003 .{ }^{610}$ Before 2003, the lead agency was tasked singly to the SC DOA. Following the codification of the enabling act, authority was then dually delegated to both the SC DOA and the SC DNR. ${ }^{611}$ This dual appointment allowed the SC DOA to address marketing and promotion, while the SC DNR now regulates law enforcement and permitting and licensure.

The SC AEA, under Chapter 18, addresses permits and licensure questions. ${ }^{612}$ The application and issuance of state aquaculture permits can be referenced under the SC AEA

\footnotetext{
${ }^{609}$ Infra Note 608 at 102.

${ }^{610}$ Code 1976, §50-18-210, South Carolina Aquaculture Enabling Act (2003).

${ }^{611}$ Id. at $§ 50-18-215$ et seq.

${ }^{612}$ Id. at $\$ 50-18-220$ et seq.
} 
also. ${ }^{613}$ Language for freshwater possession, sale, and purchase of products cultured in South Carolina is outlined under Section $50-18-225 .^{614}$ Commercial aquaculture is acknowledged under the SC AEA. ${ }^{615}$ Mandatory inspection requirement for all licensed aquaculture facilities and operations is outlined under the act. ${ }^{616}$ The State has a transfer provision under statute for aquaculture enterprises. $^{617}$ In some cases, a game retail license may be required. ${ }^{618}$ Similarly, wholesale licensure is outlined under the SC AEA. ${ }^{619}$

The State has placed regulation on the release of imported species into state waters for the protection of the public and environment. ${ }^{620}$ During the application for permit/licensure phase, prior to operation, a request to engage in non-indigenous species must be made with the SC DNR. ${ }^{621}$ In 1991, the state legislature codified a land disturbance exemption that applied to aquaculture, which allows the state industry to construct agricultural" structures without triggering violations to the Storm water Management and Sediment Reductions Act. ${ }^{622}$ Later in 1993, the legislature again called for the development of the state coastal areas under statute. ${ }^{623}$ The coastal management program allows for promotion consideration of aquaculture to occur in habitat sensitive areas.

Federal guidelines for waste management are controlled by the South Carolina Department of Health and Environmental Control (SC DHEC). Regulations are pursuant to the South Carolina Code Sections 48-1-10 et, seq. under 1976 code, which promulgated the

\footnotetext{
${ }^{613}$ Id. at $\S 50-18-235$ et seq.

${ }^{614}$ Id. at $§ 50-18-225$ et seq.

615 Id. at $\$ 50-18-230$ et seq.

${ }^{616}$ Id. at $\$ 50-18-250$ et seq.

${ }^{617}$ Id. at $\$ 50-18-280$ et seq.

${ }^{618} \mathrm{Id}$. at $\S 50-18-260$ et seq.

${ }^{619}$ Id. at $\S 50-18-255$ et seq.

${ }^{620}$ Id. at $§ 50-18-270$ et seq.

${ }^{621}$ Id. at $§ 50-18-245$ et seq.

${ }^{622}$ Code 1976, §48-14-40(a).

${ }^{623}$ Id. at §48-39-80 et seq.
} 
Pollution Control Act (Bureau of water: SC Department of Health and Environmental Control, 2008).

The industry of aquaculture in South Carolina cultivates both marine and freshwater species that includes the following: clams, crabs, shrimp, eels, and finfish, etc. Commercially, South Carolina is on the forefront of fisheries stock replenishment, supplementing stocks of redfish, cobia, and other species. Generally known for its vast coastline and favorable climate for aquaculture cultivation, South Carolina has the capacity to expand its current aquaculture production. Reports from 2005 suggest that South Carolina had approximately 85 farms producing aquaculture products valuing $\$ 4.7$ million dollars. Overall, South Carolina, as an aquaculture producing state, is small in nature but growth is a possibility. ${ }^{624}$

\section{South Dakota}

Thorough research presents only one statutory reference pertaining to liability for product disparagement for the State of South Dakota. ${ }^{625}$ Like Louisiana, in 1994 South Dakota sought to protect its valuable agriculture stock by codifying legislation to ensure that perishable products would not be diminished without repercussion for such degrading action or activity.

According to a telephone conference with the state NASAC contact, no development act or plan was ever drafted for the industry. The state Department of Natural Resource (SD DNR) controls access to surface waters and discharges subsequent. Bait dealers culturing fathead minnows must be licensed under the SD DNR for any pond culture or sale. ${ }^{626}$

It was also discussed with a South Dakota producer via telephone conference that rainbow trout production occurs on a small scale, in the Black Hills region of the state, through private pond operations or for restocking purposes under (SD DNR) permit approval. Eastern

624 Telephone conference, Chad Truesdale, May 2010.

${ }^{625}$ SDCL $\S 20-10 A-1$ et seq.

${ }^{626}$ Telephone Conference, Sarah Jorgenson, July 2010. 
Central region production is predominantly restocking for recreational fishing purposes. Some tilapia production occurs for local food markets. Overall, a very small industry exists in South Dakota. $^{627}$

\section{Tennessee}

When researching aquaculture for states grouped in the Southern Region, it was recognized that formal industry enactment as a trend took two-five years to occur. For Tennessee, organizing a timeline helps to solidify this point. In 1991, the state legislature codified Act 481, known today as the Tennessee Aquaculture Policy Act of $1991 .^{628}$ Also under Act 481 , the state legislature added provisions for an aquaculture advisory board. ${ }^{629}$ Later in 2008, the state aquaculture policy act's Sections 101-105 were repealed. Also, under the same legislative session, Act 481's Sections from 105-125 were reserved for unknown reasons. ${ }^{630}$ It was suggested during a telephone conference with a state regional extension agent that this restructuring of the industry's main legislation occurred due to a lack of infrastructure and political backing. ${ }^{631}$

The State currently has statutes remaining -n the books" for both catfish and hybrid striped bass. $^{632}$ Tennessee has referenced aquaculture under its tax code, which is important for potential aquaculturists to note concerning agricultural income designations. ${ }^{633}$ According to research conducted regarding waste management practices, the State designates the Department of Environment and Conservation (TN DEC) for regulation. Aquaculture is cited as an

\footnotetext{
${ }^{627}$ Telephone Conference, John Lott, August 2010.

${ }^{628}$ TN ST §43-33-101 et seq., Tennessee Aquaculture Policy Act of 1991. Added by 1991 Pub. Acts. c. $481, \S 1$. Later repealed by 2008 Pub. Acts, c.622, §2, eff. July 1, 2008.

${ }^{629}$ Id. at §43-33-102 et seq., Later repealed by 2008 Pub. Acts. c. 622, §2, eff. July 1, 2008

${ }^{630}$ Id. at \$43-33-105-125 (Reserved by Legislature in 2008).

${ }^{631}$ Telephone Conference, David K. Amonett, June, 2011.

${ }^{632}$ T.C.A. §53-1-102(17)., \& T.C.A. §43-33-126 et seq.

633 Id. at §67-5-1004 et seq.
} 
alternative technology" based on 1984 legislation, referenced under Chapter $221 .{ }^{634}$ Alternative technology, according to the state legislature, provides for proven wastewater treatment processes normally requiring water reuse or the elimination of pollutant discharges.

A telephone conference with the state NASAC contact revealed that freshwater prawn production appears to have the largest sector of production, with approximately 35 registered producers in state, while catfish and tilapia production are also viable means of aquatic culture. Some baitfish culture occurs for recreational purposes. In summary, the State lacked solid infrastructure to allow for adequate growth of the industry; and until this problem is solved, production levels will remain low. ${ }^{635}$

\section{Texas}

Under Section 11.005(b)(2), Texas recognizes aquaculture is agriculture, on the condition that a person so engaged does so for the purpose of wholesale or retail sale of aquaculture related products. ${ }^{636}$ In 1989, the state legislature formally codified aquaculture under Chapter 134 of Title Six of the state Agriculture Code. ${ }^{637}$ Section 134.002 outlines departmental duties of the Department of Agriculture (TX DOA) to indirectly act as the lead agency for aquaculture. ${ }^{638}$ The responsibility of the agency includes promotion of industry products, provision of technical assistance, and coordination of support with higher education and other governmental agencies, inter alia. ${ }^{639}$ The Texas act outlines the other governmental agencies involved in aquaculture regulation in the state to include the Texas Natural Resource Conservation Commission, (TX NRCC), the Texas Animal Health Commission, (TX AHC), and the Parks and Wildlife

\footnotetext{
${ }^{634}$ Id. at $\S 68-221-803(1)$., Added by 1984 Pub. Acts. c. $768, \S 3$.

${ }^{635}$ Telephone Conference, Dan Strasser, August, 2010.

${ }^{636}$ TX AGRIC $\$ 11.005(b)(2)$.

${ }^{637}$ TX AGRIC T.6, Subt. A, Ch.134., Texas Aquaculture Legislation (1989).

${ }^{638}$ Id. at $\$ 134.002$.

639 "among other things"
} 
Department, (TX PWD). ${ }^{640}$ The TX PWD has a provision in Chapter 134, authorizing the agency to issue rules and regulation on a conditional basis, not to violate the exotic species legislation referenced under Section $134.020 .^{641}$

More specifically, a memorandum of agreement is clearly outlined, describing the regulatory relationships required by both TX NRCC and TX PWD for the management of waste water discharge, application review, and the management of sensitive aquatic habitat along the state coastal zone. ${ }^{642}$ For potential aquaculturists, additional requirements for shrimp culture in coastal environments exist under Chapter $134 .{ }^{643}$

Licensing inquiries are directed to the TX PWD for those businesses that are required to obtain licensure. ${ }^{644}$ Any potential aquaculture enterprise must provide a copy of each aquaculture license to both the TX PWD and the TX NRCC. Final application for licensure will not occur until the state approves a waste water disposal plan for a given facility. ${ }^{645}$ Licensure fees can be addressed under statute contained in Chapter $134 .^{646}$ Potential aquaculture enterprises must reference the culture and sale requirement that must be checked with the TX PWD. Wholesale fish dealer licenses are not required if the individual can show compliance with Section 134.011. ${ }^{647}$ If products are transported via truck, then a license must be held to be compliant with Section 134.012. ${ }^{648}$ If an individual holds a valid aquaculture facility license, then an exemption for retail fish dealer's license occurs on the condition that products are

\footnotetext{
${ }^{640}$ Id. at $\$ 134.004$.

${ }^{641} \mathrm{Id}$. at $\S 134.005$ et seq.

${ }^{642}$ Id. at $\$ 134.031$.

${ }^{643}$ Id. at $\S 134.013$ et seq.

${ }^{644}$ TX, Parks and Wildlife Code, $\S 66.111$.

${ }^{645}$ TX. AGRIC §134.011, et seq.

${ }^{646}$ Id. at $\$ 134.014$ et seq.

647 TX PARKS \& WILD §47.009(c).

${ }^{648}$ Id. at $§ 47.010(b)$.
} 
cultured on the licensed premise. ${ }^{649}$ Potential bait dealers may be exempt from holding a TX PWD license if they are compliant with Section $134.011 .^{650}$

Some species of fish do not require licensure, thus Chapter 134 outlines a definitive listing which addresses questions on this issue. ${ }^{651}$ An exotic species list exists for the state aquaculture industry. ${ }^{652}$ Regulation under the state Parks and Wildlife code, referencing Chapter 66 concerning exotic harmful fish, shellfish, and aquatic plants, must be checked before importation or culture. ${ }^{653}$ Redfish and speckled sea trout production is regulated under Section 134.019. ${ }^{654}$ During the research phase for the State of Texas, it should be noted that statutes pertaining to cultured fish processing plants have been repealed. ${ }^{655}$

The State has codified legislation to protect the state waters with regard to aquaculture discharges. ${ }^{656}$ Under Chapter 26, discharge permits for aquaculture facilities since 1999 are a requirement. The fees associated can be referenced also under Section 26.0292. ${ }^{657}$

Under Chapter 143 of the State Advanced Technology Program, the state legislature recommends technological support by way of research, coordinated with an advisory panel, so that development possibilities are promoted. ${ }^{658}$ Additionally, the State has promulgated a force majeure" provision under statute that protects agricultural products with respect to natural disasters, under its contingency fund. ${ }^{659}$ Questions pertaining to grant access can be answered by

\footnotetext{
${ }^{649}$ Id. at $\S 47.011(c)$.

${ }^{650}$ Id. at $\S 47.014(\mathrm{c})$.

651 TX AGRIC $\$ 134.018$ et seq.

652 Id. at $\$ 134.020$ et seq.

653 TX PARKS \& WILD $§ 66.007$ et seq.

${ }^{654}$ Id. at $\S 134.019$ et seq.

655 TX AGRIC T.6, Subt. A, Ch.134, §134.032-036., Repealed by Acts 1991, 72 ${ }^{\text {nd }}$ Leg., ch. 491, §12, eff Sept. $1,1991$.

${ }^{656}$ TX WATER $\$ 26.0345$ et seq.

${ }^{657}$ Id. at $\$ 26.0292$ et seq.

${ }^{658}$ VTCA, Education Code $\$ 143.003$.

${ }^{659}$ V.T.C.A., Government Code $§ 418.073(c)(1)$.
} 
reviewing Chapter $134 .{ }^{660}$ Like other southern states, in 1995 Texas added a protective statutory provision for its agricultural products" that applies to aquaculture. ${ }^{661}$ The false disparagement provision for perishable foods prevents individuals from releasing inaccurate information that would decrease the marketability of aquatic cultured products.

\section{Utah}

Review of Utah's state statutes reveals that it may hold one of the oldest pieces of aquaculture legislation in the U. S., being codified in $1953 .{ }^{662}$ Known as the Aquaculture Act," section 102 declares aquaculture as agriculture and, therefore, subject to any law designed to provide advancement, protection, or overall benefit afforded to the traditional" agriculture industry. ${ }^{663}$ The statute goes further to require the Department of Agriculture (UT DOA) ${ }^{664}$ to work concurrently with other state agencies, such as the Department of Natural Resources (UT DNR), in order to enforce their laws and rules as well. ${ }^{665}$ Based on the language of the Utah Act, it is assumed that the lead agency for aquaculture is the UT DOA.

To ensure cooperative working environments among the state regulatory agencies, the Utah legislature codified a provision referenced, under Section 4-37-106 that allows for a memorandum of understanding (i.e working agreement) to be entered into by the agencies. ${ }^{666}$ Originally, the legislature enacted an aquaculture advisory board; but since 1998, it has been repealed. ${ }^{667}$ Unlike other states, Utah has quite a large aquaculture act, with multiple sections for the differing sectors of the state industry.

\footnotetext{
${ }^{660}$ TX AGRIC $\S 134.021$ et seq.

661 TX CIV PRAC \& REM $§ 96.001$ et seq., Added by Acts $1995,74^{\text {th }}$, ch. $80, \S 1$.

662 U.C.A. 1953 §§ 4-37-1 to 4-37-4, renumbered §§4-37-102 thru 105 by Laws 1994, c. 153, §2-5, eff. July 1, 1994.

${ }^{663}$ UT ST §4-37-102 et seq.

${ }^{664}$ U.C.A. 1953 §4-37-109.

${ }^{665}$ Id. at §4-37- 104 (1b) (2a)\&(2b).

${ }^{666}$ Id. at $§ 4-37-106$ et seq.

${ }^{667}$ Id. at §4-37-107 et seq., Repealed by Laws 1998, c. 302, §9, eff. May 4, 1998.
} 
Consequently, permitting is more complex, wherein the Division of Wildlife Resources (UT DWR) must be accessed to determine what permits are required, what certification is available and so forth. ${ }^{668}$ Regulation of transportation and importation of aquaculture is also found under the same designation. ${ }^{669}$ Utah thoroughly outlines prohibited activities under part two of its act. ${ }^{670}$ Mandatory inspection of facilities is required for compliance under R657-169. ${ }^{671}$ Facility certification is mandated to remain in operational compliance with the State ${ }^{672}$ Facility transportation of aquatic animals requires departmental notice and a valid certificate of registration. ${ }^{673}$ The sale of aquatic products cultured in aquaculture facilities first must be able to show valid certification and registration with the state. Next, accurate sale record keeping must be taken and represented to state regulatory agencies, if transported out of state. ${ }^{674}$

Part four of the Utah act outlines the importation of aquatic animals. Individuals seeking to import aquatic animals must consult the state Wildlife board for certification approval. ${ }^{675}$ Beyond certification, the State requires any aquatic animal entering the state be accompanied by accurate documentation to be submitted to the state Wildlife board. ${ }^{676}$ With the documentation submission, a health approval number will be assigned by the state and returned to the source facility. Similarly as part of this importation process, individuals must comply with health approval requirements also prescribed within the state act. ${ }^{677}$ Following compliance with Section 4-37-110, inspections pending the health approval report must occur. ${ }^{678}$

\footnotetext{
${ }^{668}$ R657-16-3 et seq., R657-16-4 et seq.

669 U.C.A. 1953 §4-37-203.

${ }^{670}$ Id. at §4-37-109 et seq.

${ }^{671}$ Id. at $§ 4-37-110$ et seq.

672 Id. at §4-37-201 et seq.

${ }^{673}$ Id. at §4-37-203 et seq.

${ }^{674} \mathrm{Id}$. at $\S 4-37-204$ et seq.

${ }^{675} \mathrm{Id}$. at $\S 4-37-401$ et seq.

${ }^{676}$ Id. at §4-37-402 et seq.

${ }^{677}$ Id. at §4-37-501 et seq.

${ }^{678}$ Id. at §4-37-502 et seq.
} 
Section 503 of the act mandates immediate creation of a Fish Health Policy Board to establish policies for the prevention of potential outbreaks of, to control the spread of, or to eradicate pathogens contracted by aquatic animals. Members of the Board are appointed by the Governor of the State, under Subsection 4(a) to include the following ex officio members: a member of the UT DNR, UT DOA, two members from non-profit sport fishing promotion and also two non-profit producers from industry. At large members include members of higher education (fish pathology, parasitology or fish pathology).

Specifically, under Chapter 15 of the Wildlife Resources Code, private fish ponds are exempt from certification registration when receiving aquatic animals from aquaculture facilities. ${ }^{679}$ Though, any questions concerning certification requirements must be addressed with the Wildlife Board promulgated under Title $63 \mathrm{G}$ of the state code. ${ }^{60}$

Questions pertaining to the licensure or permit requirements for individuals engaging in the sale, trade, or barter of wildlife must comply with regulation under Chapter 19 of the state Wildlife Resources Code. ${ }^{681}$ Private fish ponds receiving aquatic animals from aquaculture facilities are exempt from holding takings tags" for aquatic species. ${ }^{62}$ This exemption only applies if the individual owning and/or operating this type of business receives the animals from a facility that received a health approval number pursuant to Section $501 .^{683}$

Fee Fishing operations covered by aquaculture production are governed by the Utah act. ${ }^{684}$ When aquaculture enterprises transfer ownership of production stock for fee fishing

\footnotetext{
${ }^{679}$ Id. at $\$ 23-15-10$ et. seq.

680 Id. at $\$ 23-15-10$ (4)(a)(b)(c).

${ }^{681}$ Id. at $\S 23-19-1$ et. seq.

${ }^{682}$ Id. at $\S 23-19-1(3)(a)(b)(c)$.

${ }^{683}$ Id. at $\S 23-15-10(3)$ et seq.

${ }^{684}$ Id. at $\S 4-37-301$ et seq.
} 
operations as a means of restocking, statutory provisions apply. ${ }^{685}$ The transportation of aquatic animals to fee fishing operations requires checking requirements under the Utah act. ${ }^{686}$ The actual sale and licensure provisions are also contained in part three of the act. ${ }^{67}$

\section{Vermont}

In 1993, the State of Vermont enacted legislation mandating the no-cost testing of cultured aquatic species by methods of aquaculture production. ${ }^{68}$ Concurrently, under Title 10, all health testing mandated pursuant to Title 6 of state code will occur jointly through the state Department of Agriculture (VT DOA) and Department of Fish \& Wildlife (VT DFW). ${ }^{689}$ Unlike other states, the information obtained for Vermont is limited in spite of multiple attempts to reach the state expert.

\section{Virginia}

Virginia has encouraged promotion of aquaculture as a viable state industry under Title 3.2 of the Agriculture, Animal Care, and Food Code, to offset commercial deficits in revenue. ${ }^{690}$ This strong declaration notes the potential for alternative sources of feedstock" for reducing our country's reliance on foreign supplies of fish-based products. ${ }^{691}$ Aquaculture regulation is also referenced as an agricultural-focused activity" under Chapter 4, the Agricultural Stewardship provision promulgated under Title 3.2. ${ }^{692}$ A seven member advisory board was established under Chapter 26 of state code, following the promulgation of the state development act in $1995 .{ }^{693}$ The state Marine Resource Commission (VA MRC) had significant input during the research

\footnotetext{
${ }^{685}$ Id. at $§ 4-37-302$ et seq.

${ }^{686}$ Id. at $§ 4-37-303$ et seq.

${ }^{687}$ Id. at §4-37-304-305 et seq.

6886 V.S.A. $\S 1154($ a) et seq.

68910 V.S.A. $\$ 5207$ (b).

${ }^{690}$ VA Code Ann. §3.2-108 (Formerly cited as VA ST. §3.1-14.5).

${ }^{691}$ Id. at $§ 3.2-108(1) \&(4)$.

${ }^{692}$ VA Code Ann. §3.2-400- (Definitions). (Formerly cited as VA. ST. §3.2-400).

${ }^{693}$ VA ST T. 3.2 Subt. II, PT. (§3.2-2600).
} 
phase of the development legislation three years earlier in 1992, though no formal statutory reference was found. While no formal declaration was found in statute review, the language describing the duties of the board found referencing Chapter 26, suggests the lead agency on aquaculture is the state Department of Agriculture (VA DOA). ${ }^{694}$ Separately, another formal producer-driven association has been created called the Virginia Aquaculture Association (VA AA), which focuses on trout, soft-shell crab, and other fish species production (Virginia Aquaculture Association (VA AA), 2007-2011).

Virginia has implemented a -ne-stop-shop" style permit to alleviate application congestion among concurrent agencies, significantly reducing the wait time normally associated with any application process. In the State, most trout farmers are held to NPDES permitting standards, where most production occurs for the purpose of restocking rather than traditional food markets. Marine production for little neck clams and other shellfish occur seasonally. Virginia has found a niche market for cobia, hybrid striped bass, and tilapia production utilizing re-circulating systems year-round for recreational restocking and also food production. Trends provided from the NASAC contact suggest that lately the hybrid striped bass production has seen the greatest movement. Demand for trout follows the national trend of little or no growth. ${ }^{695}$

In 1999, the State of Virginia provided fisheries grant access to allow for growth of aquaculture. ${ }^{696}$ The legislature acknowledged the importance of advancing seafood technologies" through research and development. Thus, the state marine aquaculture sector served to benefit from funding access provided through this initiative. Grants were to be issued on the conditional basis that species researched were not initially heavily invested so as to

\footnotetext{
${ }^{694}$ Id. at $\S 3.2-2602$ et seq.

695 T. Robins Buck, Telephone Conference (July, 2010).

${ }^{696}$ VA ST $\S 28.2-245(b)(3)$ et seq.
} 
diversify production possibilities for the state ${ }^{697}$ Following the implementation of the fisheries resources grant program, an advisory board specifically was promulgated to oversee the program and appropriate the grants accordingly. ${ }^{698}$

The State has regulated its shellfish culture specifically under Chapter $5 .{ }^{699}$ Potential harvesting occurs only once an individual or enterprise has obtained the necessary licensure. ${ }^{700}$ Harvesting seasons must be referenced by reviewing Chapter 5 to ensure an aquaculture operation is not in violation with the state. Similarly, the State has delineated oyster planting areas under its regulated oyster program, which establish opportunities for aquaculture production. ${ }^{701}$ The State has also established a leasing program pursuant to Section 28.2-603 for stimulating growth of the state oyster production. ${ }^{702}$

Virginia in 2004 amended prior legislation that related to water column leasing for aquaculture. $^{703}$ The statutory amendment pended on fiscal appropriation, which was later deemed in 2006 not effective. The lack of fiscal support in Virginia ended this growth potential for the industry much like in other states.

\section{Washington}

Aquaculture legislation in the State of Washington was found under Title 15 of the Agriculture and Marketing code. ${ }^{704}$ The state legislature was explicit in its declaration that aquaculture provides quality sustenance, establishes employment, increases agricultural farm stability, and improves trade balances. The State delegates the Department of Agriculture as lead

\footnotetext{
${ }^{697}$ Id. at $\S 28.2-245$ (c) et seq.

${ }^{698}$ Id. at $\$ 28.2-246$ et seq.

${ }^{699} \mathrm{Id}$. at $\$ 28.2-500$ et seq.

${ }^{700}$ Id. at $\$ 28.2-501$ et seq.

${ }^{701}$ Id. at $\$ 28.2-603$ et seq.

702 Id. at $§ 28.2-603.1-613$ et seq.

${ }^{703}$ Id. at §28.2-1600-1623., Amended by Acts 2004, c. 892, eff. July 1, 2005.

${ }^{704}$ WA ST T. 15, Ch. 15.85 et seq., Washington State Aquaculture Development Legislation.
} 
principal" agency (WA DOA) to oversee agricultural marketing and promotion; but it does not forget to delegate the Department of Fish and Wildlife (WA DFW) with aquatic disease management. ${ }^{705}$ Unlike other states, Washington places its cultured species list in the definitions section of its development legislation. ${ }^{706}$ Rule-making by the WA DOA is pursuant to Chapter 34.05 RCW, to coincide with the development legislation under Chapter $15.85 .^{707}$

Aquatic disease control statutes can be referenced under Chapter 75 of the state code. ${ }^{708}$ In 2000, much of the disease control statutes formerly contained in Chapter 75 were re-codified to Chapter 77 and have since been repealed. ${ }^{709}$ Still remaining on the book, section 77.115.010 calls for mandatory disease inspection for aquaculture operations. ${ }^{710}$ Aquatic enterprise registration is required for compliance also under the same article of code. ${ }^{711}$

In the absence of the majority of legislation originating under chapter 77, Title 16 covers aquaculture animal health measures. ${ }^{712}$ Agricultural quarantine provisions are discussed under Section 16.36.010. ${ }^{713}$ Rules pertaining to inspection and testing are later discussed under Chapter $16.36 .^{714}$ Transportation requirements, which may include aquaculture, can be referenced to ensure compliance. ${ }^{715}$ Similarly, importation provisions would be triggered if an aquaculture enterprise attempts to introduce species into the State. ${ }^{716}$ Aquaculture operations

\footnotetext{
${ }^{705}$ Id. at $\$ 15.85 .010$ et seq. \& $\$ 15.85 .030$ et seq.

${ }^{706}$ Id. at $\$ 15.85 .020(3)$ et seq.

${ }^{707}$ Id. at $\$ 15.85 .040$.

${ }^{708}$ WA ST $§ 75.115 .010$ et seq.

${ }^{709}$ Repealed by Laws 2000, Ch. 150, §2, eff. July 1, 2001.

${ }^{710}$ Id. at $\$ 77.115 .010$ et seq.

${ }^{711} \mathrm{Id}$. at $\$ 77.115 .040$ et seq.

712 WA ST $\S 16.36$ et seq.

${ }^{713}$ Id. at $§ 16.36 .010$ et seq.

${ }^{714}$ Id. at $§ 16.36 .040$ et seq.

${ }^{715}$ Id. at $\$ 16.36 .045$ et seq.

${ }^{716}$ Id. at $\$ 16.36 .050$ et seq.
} 
have a duty under Chapter 16.36 to report any disease to the WA DFW to ensure outbreak does not occur. $^{717}$

Environmental management is a priority for Washington State. In 1989, the State legislature codified statutes protecting ocean resources specifically which involve aquaculture production. $^{718}$ Under this legislation, plans were to be drafted to mitigate adverse social and economic impacts" that may affect aquaculture production or recreational uses of the coastal environments. ${ }^{719}$ Beyond strategic planning, a permit structure was to be created for activities, such as aquaculture, that use and rely on coastal environments as part of their production schemes. Similarly, the State enacted legislation that balances environmental considerations with growing economic value of industries such as aquaculture. The state marine waters planning and management statutes recognize the importance of maintaining a healthy, viable coastal environment, much like the ocean resources legislation did, but these statutes incorporate plans to also encourage aquaculture. ${ }^{720}$ Following these stated goals, the legislature began to develop a comprehensive marine management plan that encouraged aquaculture development in $2010 .^{721}$

The state geoduck industry is a heavily regulated production sector found during the statutory research phase. Washington State has implemented a sea grant research program for the species. ${ }^{722}$ General rules as a guideline for the geoduck industry can be referenced under chapter $43.21 \mathrm{~A}^{723}$ A leasing program for geoduck production and harvest exists in the State. ${ }^{724}$

\footnotetext{
${ }^{717}$ Id. at $§ 16.36 .080-.084$ et seq,

718 WA ST $\S 43.143 .005$ et seq.

719 Id. at $§ 43.143 .030(e)$.

${ }^{720}$ Id. at $\$ 43.372 .005$ et seq.

${ }^{721}$ Id. at $\$ 43.372 .040$ et seq.

${ }^{722}$ Id. at §28B.20.476 et seq.

${ }^{723} \mathrm{Id}$. at $\$ 43.21 \mathrm{~A} .681$ et seq.

${ }^{724}$ Id. at $\S 79.135 .100$ et seq.
} 
Tidal waters geoduck production is covered under the program. ${ }^{725}$ It is important to note that during the research phase it was found that historical recognition of ownership of tidal areas where shellfish are cultured has traditionally been critical to the development of the State's shellfish industry Inspection requirements exist for the geoduck leasing program. ${ }^{726}$

Under the Fish and Wildlife code referencing Chapter 77.12, commercial aquaculture species are regulated with the majority being some form of shellfish. ${ }^{727}$ Normally, licensure pertaining to shellfish culture would need to be held, but any individual compliant with the state aquaculture regulation, citing Section 15.85, may be exempt from this requirement. ${ }^{728}$ Finfish regulation tends to be operated in a different fashion in Washington State. Salmon culture requires compliance with Chapter $77.95 .{ }^{729}$

A telephone conference with the state NASAC contact suggested that permitting is the greatest hindrance to industry growth. Convoluted permit structures, coupled with long wait periods, make industry start-up a time consuming process, not to mention quite costly. The State permits aquatic waste through a state driven discharge permit program. Normally, finfish culture operations are required to apply for discharge permits. In the State, marine culture predominates as shellfish culture is a large sector, but salmon culture does exist in the coastal areas. Freshwater culture occurs as a means of normal flow-through production systems, where few producers utilize privately owned aquifers. Most freshwater production is subject to public leasing programs through the state. Washington State is one of the largest egg exporters of trout. .$^{730}$

\footnotetext{
${ }^{725}$ Id. at $§ 79.135 .110$ et seq.

${ }^{726} \mathrm{Id}$. at $§ 79.135 .130$ et seq.

${ }^{727}$ Id. at $\$ 77.12 .020(8)(b)$.

${ }^{728}$ Id. at $\$ 77.65 .490(3)$ et seq.

${ }^{729}$ Id. at $\$ 77.95 .010$ et seq.

${ }^{730}$ Telephone Conference, Dan Swecker, July 2010.
} 


\section{West Virginia}

The commercial industry existed before the 1990's, with the first attempt at aquaculture legislation occurring in 1999. Prior to the most recent revision, aquaculture had been referenced in some language in approximately 27 different articles of code. In early spring 2010, a group of researchers consisting of members representing higher education from West Virginia University, the state aquaculture association (WV AA), and state legislature, worked to finally codify aquaculture under one single article. Recently, the State of West Virginia amended its aquaculture development legislation to be contained under one article code which can be referenced by reviewing Chapter $19 .^{731}$

The state aquaculture development act, the state Department of Agriculture has been classified as lead agency for aquaculture. ${ }^{732}$ Chapter 19 calls for the creation of an aquaculture advisory board. ${ }^{733}$ The state development legislation requires the WV DOA to be responsible for developing a strategic aquaculture plan. ${ }^{734}$ West Virginia's development legislation is short in comparison to other states, but it was drafted in such a manner as to allow the WV DOA to pass recommendations, resulting in rules and regulations to further establish the industry.

West Virginia's waste disposal legislation is referenced under Chapter $22 .^{735}$ There has been focus on waste designations, which have been considered a constraint for producers in the state. According to the sludge management provisions under statute, rules pertaining to beneficial use sludge disposal do not apply to land-based aquaculture facilities. ${ }^{736}$ The State has

\footnotetext{
${ }^{731}$ W.Va. Code, $\$ 19.32$ et seq., West Virginia Aquaculture Development Legislation (2010).

732 Id. at $\$ 19-32-4$ et seq.

${ }^{733}$ Id. at $\$ 19-32-5$ et seq.

${ }^{734}$ Id. at $\$ 19-32-4(7)$.

${ }^{735}$ WV ST $\S 22-15-22$ et seq.

${ }^{736} \mathrm{Id}$. at §22-15-22(c).
} 
also enacted a water resources protection and management act referenced under Chapter $22 .^{737}$ The state water act was promulgated as a matter of public policy to protect and conserve the water resources of the state for the public welfare. Aquaculture is recognized as a farm-use," which suggests aquaculture is an agricultural pursuit; a designation that until recently has caused inter-agency confusion concerning who has the right to regulate the state industry.

As a whole, before the most recent addition of revised legislation, West Virginia produced approximately $\$ 2$ million dollars worth of stock. A telephone conference with the state NASAC contact revealed that, before growth can be seen; regulatory constraints must be first addressed. Unique to the State, West Virginia producers have been known to utilize -elean" mine water pumped out of abandoned, reclaimed mine sites as viable sources of water for production of trout. Trout is the dominant fish produced while bass, carp, catfish, baitfish, and some salmon culture occur throughout the state. ${ }^{738}$

\section{Wisconsin}

The State of Wisconsin designates aquaculture as an agriculture process" under statute. $^{739}$ In 1999, the State proposed legislation that would codify the implementation and operation of an aquaculture demonstration facility. This facility would be created and enforced by a regent board of the state higher education system. ${ }^{740}$ The State has placed a provision, under the farmland preservation code, to promote resource conservation that would positively affect development for the state industry. ${ }^{741}$ The lead agency in Wisconsin is the state Department of Agriculture (WI DOA), based on historical reference delegating statutory

\footnotetext{
${ }^{737}$ Id. at $\$ 22-26-1$ et seq.

${ }^{738}$ Telephone Conference, Rob Nichols, August, 2010.

${ }^{739}$ W.S.A. 29.181. (Subchapter III: Hunting, Trapping, and Fishing Approvals).

${ }^{740}$ W.S.A. 36.11 (36) et seq.

${ }^{741}$ W.S.A. $91.01(a)(5)$.
} 
authority in $1993 .^{742}$ As lead agency, explicit goals have been set forth under the Agricultural Diversity Code to promote and develop the industry. Also, it is mandated that the WI DOA work in conjunction with both the state Department of Natural Resources (WI DNR) and state higher education to achieve these proposed goals. ${ }^{743}$

${ }^{742}$ Id. at $93.01(1 b)(1 d)$. \& W.S.A. $\$ 93.46(1 \mathrm{~m})(a)$.

${ }^{743}$ Id. at $\S 93.46(2),(3)$. 


\section{CHAPTER 4}

\section{FINDINGS}

\section{PURPOSE OF STUDY}

Initially, the research focus was to investigate the current state regulatory structures for the domestic U. S. aquaculture industry. Then it was posed that the research should expand one step further to conduct a general examination of the importance of understanding how regulation relates to economic development, in order to provide direction for aquaculture development in the State of West Virginia. In an attempt to organize and interpret the massive amount of data, regulation was evaluated against 2007 amended aquaculture census data released by the National Agriculture Statistic Service (NASS) under the USDA. A two- phase approach was utilized.

\section{TWO-PHASE ECONOMIC ANALYSIS}

\section{Phase One}

The objective for Phase I was to evaluate the individual state contributions to overall U.S. aquaculture production for two separate years, 1998 and 2005 (see Table 1). These two years were utilized because they present the most current data available through NASS in order to examine the impact of regulation on industry production success. Phase I was to compare three of the largest producing states against three of the smallest producing states, in view of their respective regulatory environments. Data from NASS was compiled into an Excel worksheet where a comparison evaluation of an individual state's contribution to aquaculture production against the U.S. total value of production was performed (see Figure1 \& 2). 
A simple method for formulating individual state contribution to total aquaculture production value is as follows:

$$
\text { State Contribution }=\frac{\text { Individual State Value }(\text { Year })}{\text { Total U.S.Production Value }(\text { Year })}
$$

Where:

1. Years evaluated are 1998 \& 2005,

2. State totals are based on NASS Amended Census Data released in 2007,

3. Data analyzed only represents reported total value, not separate culture categories.

The results from Phase I express that in 2005, three of the largest producing states were Mississippi, Alabama, and Louisiana (see Figure 5). On the other end of the spectrum, three of the smallest producing states included Nevada, Alaska, and Montana (see Figure 6). In looking back at the year 1998, production contribution data suggests that three of the largest producing states were Mississippi, Arkansas, and Washington (see Figure 7). Three of the smallest producing states for that year were found to be Nevada, West Virginia, and South Dakota (see Figure 8). In reviewing both figures, it is apparent that the following states had significant changes in overall production contribution between the two years: Maine, Georgia, Alabama, Alaska, Louisiana, and New York (see Figures $1 \& 2$ ). Specifically, three states increased their production capacities while the other three states reduced in production values.

It is assumed that changes in regulation have some impact on variations in production in those states; though it is not readily apparent whether changes in regulations directly cause positive or negative impact without further research. For example, looking at Georgia, it traditionally has a small production volume. During the years, which are the focus of this statistical analysis, the state legislature began to repeal a significant portion of its pacific white shrimp industry legislation. This change in regulation, coupled with an overall national economic downturn, crippled production in the state as a whole. It was not until 2008 when the 
industry began to see some positive effects after the legislature, under the direction of the state DNR, assumed regulatory authority of the state industry and began to promulgate new regulation to attempt to reinvigorate production for the state industry. Additional research will be needed to evaluate new data in order to be able to effectively ascertain the significance that these changes in regulation have made on this particular industry.

Traditionally, the southern states are not affected by many of the disease concerns that occurred in some northern states in the early 2000s. Some states, like Pennsylvania, show no significant positive change in production contribution, perhaps due to the federal regulatory scheme placed to control VHS. Another example of negative regulatory change affecting an industry can be witnessed by reviewing the state of Maine. In response to an outbreak of infectious salmon anemia (ISA) introduced into the state watershed in 2001 from Norway, the USDA, citing APHIS, basically ceased all salmon production in the state. Part of the federal regulatory involvement mandated an updated management plan for salmon culturing (USDA APHIS Veterinary Services \& Maine Department of Marine Resourse \& Maine Aquaculture Association, 2008). While this was not a formal statutory requirement, it was regulation required by a federal regulatory agency.

The effect basically reduced overall production of salmon by approximately $\$ 35$ million when comparing the years of 1998 and 2005. According to a state expert, the production values have increased, but it has taken approximately a decade for the state's salmon industry to recover from the disease occurrence and the legislative response thereto. ${ }^{744}$ Further research looking at newer census data would be required to fully appreciate the changes that have occurred.

744 Telephone conference, Marcy Nelson, June 29, 2011. 


\section{Phase Two}

Phase II consists of a two-part analysis intended to evaluate the statistical percentage growth rates for both production farms and their associated values, utilizing NASS data ( see Table 2). The analysis was conducted to detect changes in growth corresponding to changes in regulation. Part I of Phase II compared the growth in number of aquaculture farms corresponding to years, 1998 and 2005 (see Figure 3 \& 4).

The formula used for the calculation of average aquaculture farm growth is as follows:

$$
A F G=\left(\left(V_{\text {Present }}-V_{\text {Past }}\right) / V_{\text {Past }}\right) \times 100 \%
$$

Where:

1. AFG represents Average Aquaculture Farm Growth Rate Percent,

2. $V_{\text {Present }}$ represents new Aquaculture Farm \# Value (2005)

3. $\quad V_{\text {Past }}$ represents original Aquaculture Farm \# Value (1998).

The results from this statistical analysis report that 23 states showed positive farm growth between the years 1998 and 2005. Those states that experienced positive growth were found to include:

Connecticut, Georgia, Illinois, Iowa, Kentucky, Louisiana, Maryland, Massachusetts, Minnesota, Nebraska, New Hampshire, New Jersey, North Carolina, Ohio, Oklahoma, Oregon, Pennsylvania, Rhode Island, South Carolina, Tennessee, Texas, Vermont, and Washington (see Figure 9: Table 7).

Conversely, 23 states showed negative growth in their total number of farms. Those states that experienced negative growth were found to include:

Alabama, Alaska, Arkansas, California, Colorado, Delaware, Florida, Hawaii, Idaho, Indiana, Kansas, Maine, Michigan, Mississippi, Missouri, Montana, North Dakota, South Dakota, Utah, Virginia, West Virginia, Wisconsin, and Wyoming (see Figure 9: Table 7). 
Three states were found to exhibit no growth out of the 50 total sampled, which included Arizona, New Mexico, and New York. The State of Nevada provided no data on farm growth. The average farm growth was calculated to be $24 \%$ across the nation, (see Table 7 ).

Part II of Phase II was concerned with the statistical analysis pertaining to the evaluation of percentage growth among state production. This same NASS census data was utilized for evaluation. By understanding changes in production value, correlations between regulation and the impact on resulting production can be made. The formula used for the calculation of percent production value rate between years 1998 and 2005 is as follows:

$$
A P G=\left(\left(V_{\text {Present }}-V_{\text {Past }}\right) / V_{\text {Past }}\right) \times 100 \%
$$

Where:

1. $A P G$ represents Average Aquaculture Production Growth Rate Percent, 2. $V_{\text {Present }}$ represents new Aquaculture Farm Production Value (2005),

3. $\quad V_{\text {Past }}$ represents original Aquaculture Farm Production Value (1998).

Based on a 50 state total sample size, 24 states were found to have positive growth in production value for the years, 1998 and 2005 (see Figure 10: Table 8). Those states that experienced positive growth in production value include:

Alabama, Arkansas, California, Georgia, Idaho, Illinois, Kentucky, Louisiana, Massachusetts, Michigan, Minnesota, Missouri, New Hampshire, New York, North Carolina, Ohio, Oregon, Pennsylvania, South Carolina, Texas, Virginia, Washington, West Virginia, and Wisconsin (see Figure10).

Nineteen states were found to have negative growth in production value, including:

Alaska, Arizona, Colorado, Connecticut, Florida, Hawaii, Iowa, Maine, Maryland, Mississippi, Montana, Nebraska, New Jersey, Oklahoma, South Dakota, Tennessee, Utah, Vermont, and Wyoming (see Figure 10).

No states exhibited no growth in production value. However, seven states reported no data and were unable to be included in the analysis. Those seven states are the following: Delaware, 
Indiana, Kansas, Nevada, New Mexico, North Dakota, and Rhode Island (see Figure 10). The average aquaculture production value growth rate percentage was found to be $23 \%$, (see Table 8).

\section{REGULATORY STRINGENCY}

This study incorporated data released by Wirth and Luzar in 2000. The significance of their publication relates the authors' findings of individual state regulatory climate to the current regulatory atmosphere found during the research phase for this case study. The authors utilized an exploratory factor analysis model, centered on the notion that location and species decisions at the producer level are directly influenced by a regulatory climate. According to Wirth and Luzar, this regulatory climate was ranked subject to the following factors:

Industry lobby, political-bureaucrats, environmental groups, recreational lobby interest, consumer groups, administrative agencies, enforcement agencies, development legislation ie. plan or act, aquaculture classification, species classification, and more specifically, region (Wirth \& Luzar, 2000).

The results of the study have been displayed in a reader-friendly method to show state stringency for the nation (see Figure 11: Table 10). The Wirth and Luzar data was crossreferenced against the current case study data for each state. The *ery high" stringency level group, set forth by (Wirth and Luzar 2000), contained states such as Maryland and Washington. Those states were found in the current case study to possess complex regulatory atmospheres in relation to other nearby states (see Figure 11). It was ironic, however, that New Hampshire and Montana were also cited by Wirth and Luzar as *ery high" stringency. Yet the current research revealed minimal or non-existent statutory references (see Figure 11). This inconsistency can be explained by the understanding that the authors incorporated a more expansive evaluation, beyond the nature of state statutory review, such as was conducted in the current research. 
Because of the limitation of this current research, future analysis into ranking" of state stringency must occur.

\section{TIMELINE ANALYSIS}

In an effort to attempt to make sense of the large amount of data collected for this case study, the research group decided that using a table to display the time line would help to discern whether there were trends that could be tracked among the individual aquaculture regions. The 50 states evaluated were placed into the following five groups: North Central Region, Northeastern Region, Southern Region, Western Region, and Tropical Region. A 61 year time span was the range displayed, due to the fact that a few states had recorded aquaculture legislation dating back to 1955 . Utah, a relatively small producing state, has the longest recorded industry based on the legislative review which established the passage of its development legislation in 1955 (see Table 11).

The majority of the legislative activity has occurred during a 20 year time span starting in 1980, when Congress solely recognized aquaculture as an industry under the 1980 Act. This point in time is when the industry indicates state development first began. However, the findings of this case study support at least five states, including Mississippi, Oklahoma, Colorado, Oregon, and Hawaii, all had legislative references predating the 1980 Act. Six states, including Montana, Nevada, New Mexico, New York, North Dakota, and Oregon, are reported with no legislative history (see Table 11). This does not mean that there is no industry activity or there is no legislative guidance - it simply means that the legislative information was not able to be located through the research methods utilized or the expert sources sought out.

A review of this time line data shows that 26 states have enacted development acts for their respective industries. Additionally, 19 of those 26 states have further developed their 
industries by establishing a development or strategic plan (see Table 11). An overall view of the time line reveals that most of the state development happened between the years of 1980 and 2000. Also, evaluating trends in the time line, several states developed their acts and plans within an average of one to four year time frame. Massachusetts is the only state to accomplish both goals in the same year, which represents a very progressive approach to aquaculture development. Some states still have only development legislation and have not proceeded to pass development plans (see Table 11).

Looking at the states by region, the Southeastern Region has the greatest depth of industry development, where each state has promulgated legislative acts and has also passed a development plan. In both the North Central Region and the Southeastern Region, three states in each region have enacted their development plans prior to passing the development legislation. It could be hypothesized that these states had industries that accommodated legislation to fit the needs of their ongoing production, in contrast to other states that developed their industry once the legislation was in place (see Table 11). 


\section{CHAPTER 5}

\section{SUMMARY, CONCLUSIONS, \& RECOMMENDATIONS}

\section{DISCUSSION}

Following the Aspen report (1981), there have been multiple attempts to quantify a model or an equation wherein constraints can be minimized to elicit an efficient aquaculture industry nationwide. To date, all such attempts have been unsuccessful, partly due to the fact that not all states possess the same geography, climate, access to natural resources and market, or political climate and support. Therefore, a uniform approach has not been devised. While one approach to development may work well in one state or region, it may need to be manipulated to achieve the same results in another.

Rather than attempt to fit every state into one mold for aquaculture development, it is better to be pragmatic and understand that every state has a potential for development. Instead, it must be tailor made to fit the needs of the individual state. Generally speaking, consider each state as a puzzle where the pieces are of differing proportion, represented by the factors required for development. Therefore, in a generic sense, in order to accomplish efficient development, an industry must rearrange the pieces to fit the puzzle.

For instance, by applying the legislative research, some states have fewer statutes regulating their industry than other states. A traditional view of development might be that greater legislative establishment would equal greater industry development. However, in states like Mississippi and Alabama, which are top producing states in the U.S., this is not the case. Both states have minimal statutory records, but their production levels are some of the highest in thenation. 
Contrary to the traditional view that greater industry potential goes along with a greater depth of statutory references, the state of Georgia vested almost a decade toward establishing its shrimp production industry, only to later repeal it and to this day has limited production compared to other states in the nearby region. Reverting back to the puzzle analogy, the legislative piece of the puzzle is not always going to be the same size or shape for each state.

A similar factor, representing another piece of the puzzle, would be the political climate or support in any particular state. Oklahoma originally had a very progressive atmosphere towards agriculture from its leadership, which was interested in pursuing non-traditional forms, such as aquaculture, to assist in its economic diversification. Over the past three decades, however, this focus has changed multiple times. The political climate and leadership has altered its emphasis to lead the state back toward more traditional farming practices like cattle production. Aquaculture as a focus of development has taken a back seat to more economically feasible programs, which required less initial investment.

The right of every state to produce represents an equal sized piece of the aquaculture puzzle. A contributing variable affecting this right is access to natural resources and to market. These factors can make the difference between a fairly simple production structure to one that requires a more organized and detailed infrastructure development approach. This point is not meant to discourage industry development in states where this constraint is greater than others, but merely to acknowledge the additional investment it would require to reach its maximized development potential. For example, Idaho has an abundant and accessible source of freshwater in the state, which makes trout production very straightforward. Very little must be done in the state of Idaho by aquaculture producers, other than obtaining permits for water consumption, in order to be able to culture their products. 
West Virginia, on the other hand, also has an abundant supply of water, however, some of it must be treated for usage after mineral reclamation. There is still a good source of water; however, it must first be treated for usage. The state's regulatory industry requires water to be treated prior to being discharged and repurposed for other industry uses, such as aquaculture. Therefore, in mineral extraction practices, it would be the responsibility of the mining companies to reclaim such water; which then would become available for usage by state aquaculture producers. The legislature basically enacted regulation to require the water mitigation as part of the reclamation $\operatorname{plan}^{745}$. This additional step, taken at face value, may appear to be a big obstacle to potential fish farmers. However, it actually allows aquaculturists the same access to fresh water as other states, such as Idaho, with the primary treatment step having been completed prior to usage for culturing of fish, without costs accrued to the producers. The point is that each state has the potential to culture fish products, however, the process to achieve this goal may be different for each individual industry. The process may require tweaking" to accommodate the individual needs and issues pertaining to access of natural resources or market in a given state.

Another factor affecting the access to market, which becomes another piece of the puzzle, is supported by the notion that marketability of aquaculture products is heavily influenced by consumer perception. It only requires one false statement regarding the quality of the products, for example, to seriously influence a customer's willingness to buy. States like South Dakota and Louisiana have enacted legislation that combats product disparagement. This form of regulation protects the value of cultured products in those states.

While consumer perception is important, the actual dissemination of credible and accurate information by industry professionals to the public is also a vital piece of the puzzle. During the research phase of this assignment, it took multiple attempts to reach so-called experts

\footnotetext{
${ }^{745}$ WV ST §22-11-(1-30) et seq.: W.Va. Water Pollution Control Act
} 
by phone or email, often unsuccessfully. Of the contacts that were made, the information provided was often inaccurate or incomplete. For example, some states were said to have no industry legislation on the books. However, they were then found through the Westlaw review to have extensive legislative references for the aquaculture industry. During some telephone conferences, the expert" was unable to answer simple questions and referred the researcher to other sources for additional information. Very few states have efficient information flow from the regulatory side to the public. Three states that were particularly noteworthy as being effective and knowledgeable were Florida, Hawaii, and North Carolina. Each of these states has experts who are well versed in the industry and have intimate knowledge of the legislative structure, as well as familiarity with general aquaculture questions. This type of support must be helpful for promotion of aquaculture in the state. That may qualify a state as aquaculture friendly."

An important constraint to development of aquaculture is the lack of infrastructure in many states regarding product processing. Most states operate without a centralized processor. In most cases, markets rely on plants located in other states to process the fish for the food markets. This activity is time consuming, is highly regulated due to interstate commerce and pathogen restriction laws, and often requires additional capital. The summation of these constraints often forces the producers to select less costly alternatives for production instead of maximizing their potentials. The limited economic feasibility resulting from this lack of infrastructure ultimately reduces food fish market access. For example, Mississippi has three centralized processors in the state, just to handle their volume of catfish production. If these processors were not available to the producers in-state, there would be a huge reduction in overall volume produced, because costs to ship out of state for processing would make it 
unfavorable to culture. This example is supported by Florida, where recently all fish food processing has been occurring in the State of Georgia, rather than Florida. As a result, Florida's food fish production has become less significant than its ornamental fish production. In Florida's case, the rise in ornamental fish production has offset the loss from its fish food production so that the industry has not been greatly harmed. A less diverse or economically resilient state may not be so fortunate.

Another consideration flowing from the legislative research involves the relation between the creation of regulation and the appearance of related impacts on aquaculture development. It has been hypothesized that either the time when legislation was enacted or the lag between legislative enactment and actual industry development would somehow predict greater or lesser success for production. This idea simply does not have merit. Some states, like Utah, had informal regulation and a significant, thriving industry for its size at least a decade before Congress enacted its first legislation. Many states had a commercial aquaculture industry before 1980, or even before policies were set - even West Virginia. Another example might be Georgia or Pennsylvania, who both enacted more recent development legislative plans, decades after Congress acknowledged the value of aquaculture. However, neither has a very active market in place. Some states just naturally have an ability to produce, such as Hawaii, whose aquaculture market has been in practice since the early $20^{\text {th }}$ century, largely due to the fact that they had no other means to provide sustenance for their people. Therefore, time is not necessarily an accurate indicator of success, but merely a representation of promotion and investment. 


\section{RECOMMENDATIONS FOR WEST VIRGINIA}

\section{"Top/Down Strategy"}

This research project is a first step in arranging the pieces to build West Virginia's puzzle for aquaculture development. During this organizational phase, the state stands to benefit from policy trial and error experienced in other states. By learning from those that have already proceeded through their developmental phases, West Virginia may avoid unnecessary constraints.

It is proposed that the most efficient approach for development in West Virginia would be a top-down strategy. This strategy incorporates industry development, beginning with the highest levels of the state government enacting -nabling" legislation to recognize and promote the state industry on a general level. This enabling legislation will allow for a regulatory agency to then further promulgate development through recommendations passed by advisory councils, higher education, and other state agencies. While this legislation does not possess great depth, it is integral to starting the development process. In essence, this legislation is the foundation upon which industry development may be built.

Once the enabling legislation is in place, a joint effort must occur between members of industry, legislative agencies and academia. This is vital because this is the level where the rules and additional regulations are developed and created as law. Next, infrastructure must be put into place. Once these two steps have been accomplished, investors must then be sought out in order to continue to foster development. The final step in this process is the maintenance stage, where all members, including the legislature, the regulatory agencies and individual producers and investors, participate in a review and revision of both the regulatory scheme and the 
infrastructure. The goal for the state is to strive to create an environment where there is incentive for development. In a general sense, the following areas must be addressed:

1. A statutory overhaul requiring the WV Department of Agriculture to act as lead agency, 2. State of West Virginia requires an aquaculture coordinator to oversee development and industry issues alike,

3. An aquaculture task force must be promulgated to pass recommendations,

4. Following the initial legislative investment, a development plan must be implemented,

5. Lastly, economic investment must incentivize continued state development.

The first recommendation has already been implemented, which was to enact the enabling legislation in the form of a single aquaculture development bill. ${ }^{746}$ Passed in 2010 under one article of the West Virginia State Code, this bill organized a procedural bare bones piece of legislation to formally establish and recognize that aquaculture is a viable, nontraditional form of agriculture in the state. Also under this act, a lead agency designation was proposed, requesting that the State Department of Agriculture, (WV DOA) be the principal authority regulating aquaculture. The Aquaculture Advisory Board was also established as part of the procedural act. By having a small act, expansion is allowed as the advisory board works to see how the pieces of this puzzle will fit together.

\section{"Policy Considerations"}

\section{Permitting}

It is at this point that the research recommends the state begin to work concurrently with other agencies. Based on the research, it is suggested that the state must first address how it will develop and regulate permitting for the industry. States like Mississippi and South Carolina have employed more efficient means of obtaining permit licensure. These states have implemented what is known as reduces the constraints on a particular enterprise seeking to be in compliance with the following

746 West Virginia Aquaculture Development Act, Infra note 2 at 8. 
areas: importation, health standards, water usage, and waste management. More specifically, by having one single permit, the time period allotted to completing the licensure process is reduced and well organized. West Virginia would benefit from this type of structure allowing easier entry into the industry. It is hereby recommended that the advisory board begin to research and promulgate legislation that will provide for the development of this type of permit system.

Of the production that occurs in West Virginia, three general production schemes can be found:

1. Fish pond - used generally for restocking purposes, 2. Indoor recirculating - used generally for food fish markets, and 3. Traditional flow through raceway design - used for mixed markets.

Many small, private fish pond production enterprises can be found across West Virginia. It is recommended that the advisory board promulgate an independent closed system culturing permit, specific to this type of production. Under this permit, specifications for waste discharge and aquatic health standards would be separate and distinct, custom tailored to this type of production scheme which takes place in a contained water body, rather than in typical flowing water production designs. The recirculating sector of West Virginia production should be included in the closed system permit structure because of its characteristic of geographic isolation which normally reuses its water resources. In contrast, a more generalized culturing permit would be envisioned for other types of production, which occur in raceways located near important watersheds, where water is diverted and then ultimately released back into the water body. Currently, trout production utilizing flowing-water systems, envisioned greatly by raceways focused designs, dominate the aquaculture industry in West Virginia.

By implementing a structure that offers two distinct types of permits that encompass specific standards for the given area of production, permit compliance will be improved with 
greater enforcement. Instead of producers having to apply for multiple permits to cover each of the different areas, the - ne stop shop" permit encompasses all needed regulation. From the regulatory standpoint, the WV DOA employs an aquaculture coordinator, responsible to be the puzzle-maker." As West Virginia progresses in its developmental stage, the potential for the coordinator's responsibilities to increase is expected. The - - ne stop shop" permitting structure will help to streamline the enforcement capacity of the coordinator.

In addition to the proposed permitting structure, this research recommends that the state industry mandate registration for all enterprises, hobby or commercial. This registration would be required on an annual basis that holds all enterprises accountable to ensure a more efficient, concise record of industry statistics. During the research phase, this was a significant hindrance to industry-wide development. More up-to-date records allow experts to release valid information to the public and potential aquaculturists. Some of the information to be filed on an annual basis would include the following:

1. Location,

2. Type of facility,

3. Aquaculture products grown or sold,

4. Quantity of products sold,

5. Estimate of value.

Additionally, the advisory board must specifically specify what products constitute -domestic" versus -wild." This issue has been faced by other states when addressing the ownership of aquacultural-based products. The mandatory registration will allow for a more thorough delineation on this topic.

"Wild v. Domestic Classification"

Nationwide, states have been troubled by how to classify aquaculture products, whether as wild or domestic. This dispute impacts how states delegate authority to regulate and overall 
impacts the producer's possessory right. Missouri as a state to note has quashed this potential development constraint by electing to classify all aquaculture products as Hivestock."747

\section{Aquatic Animal Health}

The State industry would benefit greatly from access to its own aquatic health specialist, separate from the veterinarian currently employed by the WV DOA. Not only would this individual would possess a greater depth of knowledge for the given field of aquaculture, but also would allow for a thorough dedication of time and effort to the unique needs of this industry.

Additionally, the advisory board must be urged to develop an approved and nonapproved species list for the industry. These two lists would be included as part of the initial permitting and licensure phases. Regulation of these approved and non-approved species helps protect native biodiversity and inhibits potential pathogen introduction into the state's watersheds.

The state must hold all enterprises to mandatory fish certification requirements, which are to be developed by the advisory board. These requirements would generally consist of pathogen testing for Viral Hemoragghic Septicemia (VHS), Infectious Pancreatic Necrosis (IPN), Whirling's disease, and Infectious Hematopoietic Necrosis (IHN). These are industry-crippling endemics currently faced by other states.

\section{Incentivizing Economic Development}

\section{State Processor}

Another significant addition would be improved market access through the establishment of an accessible state processor. The state originally had invested in a project to include a processor. However, due to a poor design, a lack of regulatory infrastructure, and economic

\footnotetext{
${ }^{747} 277.042(2)$, Infra Note at 82.
} 
hardship, the project failed and the processor was closed. This left a bad taste" with many advocates of aquaculture in the State of West Virginia, because of the financial investment made that was never fulfilled. Despite this outcome, opportunities and resources remain for development of an aquaculture industry in the state. Years later, joint effort of academia and industry experts, is now advocating that the state possesses the know-how to effectively and economically operate such a venture. By having a centralized processor in West Virginia, the food fish market potential may take advantage of the consumers' willingness to purchase home grown" products.

\section{"Creative Niche Market Promotion"}

To encourage development of aquaculture in West Virginia, a sustained, receptive environment supporting aquaculture must exist. Historically, this state has been synonymous with coal production. Broadening the focus to include aquaculture along with its long standing coal industry focus, can only promote the state's economy. It is in the state's vital interest to promote all agricultural opportunities, as well as the economic development initiatives, to include an industry that utilizes its own natural resources and creates a healthy, sustainable product to feed its people.

A 2003, research study conducted at WVU evaluated the feasibility of using mine water as a source for state aquaculture development. Ultimately, it was the conclusion of the study that mine water aquaculture links conservation, recreation and economic development for the future diversification of the State (D'Souza, Miller, Semmens, \& Smith, 2002).

This current project, as a whole, was aimed solely at reviewing legislative environments on a state-by-state basis: mine water production possibilities arose during this review. While this research needs to be expanded, this is certainly a viable possibility which presents a triche" 
production scheme, assisting in the marketability of state cultured products. West Virginia's mining legacy could add a new dimension, aquaculture.

To promote this —nilee" production possibility, the State aquaculture advisory board must investigate and develop legislation to promote this type of specific sub-industry. In many areas, the infrastructure (i.e. water resource) is available but small and widespread. Regulation, with respect to mineral extraction practices, is currently mandated under a state driven NPDES structure; aquaculture would simply require additional legislation to provide a definition of both access and ownership over the rights-to-use the waters of the State.

\section{“West Virginia's Reality”}

West Virginia traditionally has been viewed as a coal production state, rather than an agricultural state. To assume that West Virginia will become a top producing state maybe overzealous. Considering the amount of production in other states, West Virginia fills a small piece of the overall aquaculture production puzzle at best. However, while the State may never be a production powerhouse, like Mississippi, Idaho, or North Carolina; West Virginia has a significant opportunity for growth and expansion from its current economic status. West Virginia currently produces approximately $\$ 3$ million in stock value per year. There is no reason why, however, with the proper production development, that value could not be increased to compete with more profitable states like Pennsylvania or Washington. There is no reason why West Virginia cannot take its place as an important regional aquaculture producer.

\section{Conclusion}

This case study was designed and presented to allow a reader-friendly" environment for aquaculture industry inquiry, specifically to pertain to West Virginia's recent surge in industry development. The greatest constraint discovered during this project was a lack of credible, 
consistent information. Not only does the U.S. aquaculture industry require more working manuscripts such as this case study, but also the U.S. Agriculture sector as a whole must strive to better inform its members and public alike. Top producing states like Florida, North Carolina, Mississippi, and Alabama, all share one common theme, efficient promotion for their respective state aquaculture industries. West Virginia must rely on its Department of Agriculture to market the state's products effectively.

Like the majority of the states surveyed for this case study, West Virginia has accomplished multiple achievements during its quest to develop its aquaculture industry. Having completed a legislative development act, additional work towards an on-going strategic plan should be the next goal for the State. While many question the place of regulation in state agricultural activities, a general theme must be remembered. Regulation acknowledges and protects a given industry, such as aquaculture, and it provides a foundational framework by which a respective industry can prosper competitively. In closing, research that frames regulation's impact on agricultural pursuits, such as aquaculture, must be the focus for the future as increasing domestic production must occur to meet a growing demand for sustenance.

\section{LIMITATIONS OF STUDY}

The industry as a whole is negatively impacted by a lack of accurate and complete information that is readily available. During the initial research phase, multiple repeated contacts and review were required to attempt to obtain information from the various state sources. Cross-referencing the information gained through the telephone and email conferences with the information obtained through the major legislative review concluded that the insight provided by the experts was often inaccurate. This major limitation is a stark indicator of the environment for aquaculture development in the U.S. Based on this trend, the legislative review 
process was reformatted to ensure that the information included in this thesis was the most up-todate, accurate and useful information possible.

The original analysis occurred over a six month period, before the restructuring happened. The second analysis was summated following a year and a half of more detailed research. Not only should the State of West Virginia be vigilant to ensure that the information it releases to the general public is correct, but also the industry as a whole should be more effective in educating its experts to properly disseminate information in order to promote aquaculture development nationwide.

A major limitation of scientific research concerning aquaculture in general is the lack of understanding regarding on how to quantify the role of regulation and its impact on development. Policy based research lacks in many agricultural sectors, not limited to solely aquaculture. Most of the current research only generally discusses issues concerning regulatory development. However, there is no research which has determined the necessary scope or breadth of regulation that is required for optimal development potential. Because each state is unique, a -ne size fits all" model is unlikely to be feasible.

Further, due to the uncertain nature of regulation's role in aquaculture development, it is difficult to ascertain at this current point the influence of other external factors on development as well. Regulation alone is not the only point to consider. Other factors, reverting back to the puzzle analogy, such as climate, access to natural resources and market, political influence, and financial access to capital investment, make this a multi-dimensional consideration.

\section{FURTHER RESEARCH CONSIDERATIONS}

The scope of this thesis was to provide a thorough overview of the current legislative state of aquaculture as a digest for the newly promulgated West Virginia Aquaculture Board to 
reference as it begins to pass recommendations for further industry development. Further research may be necessary to expand the work completed here to evaluate what the state of West Virginia accomplishes as it reaches its full development potential. This current research only focuses on West Virginia in its infancy. While it is vital in its own respect, it will not accurately represent where West Virginia will go from here.

While this case study applies to West Virginia, other states may be able to use it to aid in their development processes. At a time when policy examinations are perceived to impact aquaculture industry development greater than science and economics, further research is advised. 


\section{REFERENCES}

Alaska Department of Fish and Game (AK DFG). (2011). Aquatic Farming. Juneau, AK, United States. Retrieved 01 21, 2011, from http://www.adfg.alaska.gov/index.cfm?adfg=fishingaquaticfarming.main

Arkansas Game and Fish Commission. (2000-2001). Licenses, Permits, Stamps, Tags, Costs, and Expiration Dates. Little Rock: Arkansas Game and Fish Commission.

Aspen Research and Information Center (Aspen Systems Corporation). (1981). Aquaculture in the United States: Regulatory Constraints. Rockeville, MD.

Boyd, C. E., Queiroz, J. F., Whitis, G. N., Hulcher, R., Oakes, P., Carlisle, J., et al. (2003). Best Management Practices for Channel Catfish Farming in Alabama. Special Report 1. Montgomery: Alabama Catfish Producers.

Bureau of water: SC Department of Health and Environmental Control. (2008). R.61-68, Water Classifications Standards (2008). Columbia, SC: Bureau of water: SC Department of Health and Environmental Control.

Connecticut Department of Agriculture. (N.D.). Aquaculture Permit Requirements in Connecticut. Retrieved 05 14, 2011, from Aquaculture Permit Requirements in Connecticut: http://www.ct.gov/doag/cwp/view.asp?a=1369\&Q=259186\#401

Crew, J. R., \& Chappell, J. А. (2006 йил February). Timely Information (Ag Economic Series)2005 Alabama Aquaculture Factsheet. Auburn University, Agricultural Economics \& Rural Sociology (Alabama Cooperative Extension Service). Auburn: Auburn University Extension.

D'Souza, G., Miller, D., Semmens, K., \& Smith, D. (2002). Mine Water Aquaculture as an Economic Development Strategy: Linking Coal Mining, Fish Farming, Water Conservation and Recreation. 2003 Aquaculture America Conference, (pp. 1-17). Louisville, KY.

Duff, J. A., Getchis, T. S., \& Hoagland, P. (2003). A Review of Legal and Policy Constraints To Aquaculture in the US Northeast. Portland, ME, Groton, CT, \& Woods Hole, MA: Northeasternl Regional Aquaculture Center (NRAC).

Faulds, A., \& Conklin, C. (2009). Aquaculture Sitation and Outlook Report 2009: Pennsylvania. College Park, MD: Northeastern Regional Aquaculture Center (NRAC).

Fitzsimmons, K. (1998). Review of Rules and Regulations Affecting Aquaculture in Arizona. University of Arizona. Tucson: University of Arizona.

Florida Department of Agriculture and Consumer Services. (2011). Division of Aquaculture Website. Retrieved 06 22, 2010, from Florida Aquaculture: http://www.floridaaquaculture.com/bad/aquaintro.htm

Florida Department of Agriculture, Division of Aquaculture. (2007). Aquaculture Best Management Practices Rules 2007. Tallahassee: FL Department of Agriculture.

Garner, B. A. (2009). Black's Law Dictionary (Vol. 9th). St. Paul, MN: Thomson Reuters. Georgia Department of Agriculture. (N.D.). Georgia Administrative Rules on Aquaculture Registration. Retrieved 09 24, 2010, from Georgia Aquaculture Registration: http://rules.sos.state.ga.us/cgi- 
HDR Engineering, Inc. (2010, 01 24). Fisheries \& Illinois Aquaculture Center. Retrieved 1018 , 2010, from Southern Illinois University Carbondale (Fisheries \& Illinois Aquaculture Center): http://fishdata.siu.edu/secure/bioman.pdf

Maine Department of Marine Resources (ME DMR). (2004). Governor's Task Force on Planning and Development of Marine Aquaculture in Maine (Report \& Findings). Maine Department of Marine Resources (ME DMR).

Maine Department of Marine Resources (ME DMR). (2006). Aquaculture Laws. ME, United States. Retrieved 04 11, 2011, from http://www.maine.gov/dmr/aquaculture/aquaculture_laws.htm

Maine Department of Marine Resources (ME DMR). (2006). What is Aquaculture. ME, United States. Retrieved 04 11, 2011, from http://www.maine.gov/dmr/aquaculture/what_is_aquaculture.htm

Maryland Department of Agriculture, N. A. (1995). State/Territory Permits and Regulations Impacting the Aquaculture Industry. Maryland: Joint Subcommittee on Aquaculture.

Massachusetts Aquaculture Association (MA AA). (2006). MA Aquaculture Association Official Website. Retrieved 05 24, 2011, from MA Aquaculture Association Official Website: http://www.massaqua.org/

Massachusetts Office of Coastal Zone Management (MA CZM). (1995). MA Aquaculture Strategic Plan. Boston, MA, United States. Retrieved 05 21, 2011, from http://www.mass.gov/czm/sptoc.htm

McIntosh, D., \& Ewart, J. (2009). Aquaculture sitation and Outlook Report 2009: Delaware. College Park, MD: University of Maryland.

Mississippi Department of Agriculture and Commerce (MS DOA). (n.d.). Mississippi Department of Agriculture and Commerce. Retrieved 05 13, 2011, from Bureaus \& Departments- Consumer Protection- Laws- MS Catfish Martketing Law of 1975: http://www.mdac.state.ms.us./n_library/agency_info/reg_laws/laws_conpro.html

Mississippi Department of Agriculture and Commerce (MS DOA). (n.d.). Mississippi Department of Agriculture and Commerce. Retrieved 05 13, 2011, from Marketing Development: http://www.mdac.state.ms.us./n_library/departments/marketing/index_marketing.html

Nelson, G. R., DeVoe, M. R., \& Jensen, G. L. (1999). Status, Experiences, and Impacts of State Aquaculture Plans and Coastal Zone Management Plans and Aquaculture in the United States. Journal of Applied Aquaculture, 9(1), 1-21.

Newton, G. (1978). Aquaculture: Emerging Issues of Law and Policy. Sea Grant Law \& Policy Journal, 2, 45-94.

North Carolina Aquaculture Association (NC AA). (n.d.). North Carolina Aquaculture Association: "Farming Fresh Alternatives". Retrieved 02 28, 2011, from North Carolina Aquaculture Association (NC AA)

North Carolina Department of Agriculture \& Consumer Services (NC DOA). (n.d.). North Carolina Department of Agriculture \& Consumer Services. Retrieved 02 19, 2011, from North Carolina Department of Agriculture \& Consumer Services Homepage: http://www.ncagr.gov/

North Central Regional Aquaculture Center. (2008, 05 28). North Central Regional Aquaculture Center. Retrieved 07 14, 2011, from NCRAC- Illinois-Aquaculture Contacts, Transport Regulation, and Approved Aquatic Species Lists: http://www.ncrac.org/Info/StateImportRegs/illinois.htm\#imports 
Soil and Water Engineering Technology, Inc. (2008). Preliminary Report For Project Entitled Nutrient Loading Rates, Reduction Factors and Implementation Costs Associated with $B M P$ 's and Technologies. South Florida Water Management District.

State of Alabama. (n.d.). Alabama Administrative Code- Search "Aquaculture Regulation". Montgomery, AL, United States. Retrieved 09 24, 2011, from http://alabamaadministrativecode.state.al.us/docs/agr/index.html

The Joint Subcommittee on Aquaculture of the Federal Coordinating Council on Science, E. a. (1983). National Aquaculture Development Plan. Washington D.C.: U.S. Department of the Interior.

The University of Arizona. (2011). Arizona Aquaculture. Retrieved 10 14, 2010, from Arizona Aquaculture: http://ag.arizona.edu/azaqua/

Thomas, S. K., Sullivan, R. M., Vertrees, R. L., \& Floyd, D. W. (1990). Aquaculture Law in the North Central State: A Digest of State Statutes Pertaining to the Production and Marketing of Aquacultural Products. Technical Bulletin No. 101, Columbus, OH.

U.S. Commision on Ocean Policy. (2002). U.S. Commision on Ocean Policy. Retrieved 01 18, 2011, from National Sea Grant College Program Act:

http://www.oceancommission.gov/documents/gov_oceans/Seagrant.PDF

U.S. Department of Agriculture (USDA). (2002). www.csrees.usda.gov. Retrieved 01 10, 2011, from Cooperative State Research, Education, and Extension Service (CREES) under USDA: http://www.csrees.usda.gov/about/offices/legis/pdfs/nar77.pdf

U.S. Department of Agriculture; Animal and Plant Health Inspection Service (APHIS). (2007). APHIS- Aquatic Animal Health Standards (March 2006 Report). Retrieved 08 14, 2010, from Animal Health: http://www.aphis.usda.gov/import_export/animals/oie/aquatic_mar06.shtml

Union of Concerned Scientists: Citizens and Scientists for Environmental Solutions. (2010). Union of Concerned Scientists: Citizens and Scientists for Environmental Solutions. Retrieved 03 05, 2011, from Food and Agriculture Section: http://www.ucsusa.org/

University of Arizona College of Agriculture, Department of Soil, Water, and Environmental Sciences. (2002). Arid Lands Aquaculture Newsletter. Tucson: University of Arizona.

University of Arkansas, Division of Agriculture, Research, \& Extension. (2011). Arkansas Aquaculture. Retrieved 12 28, 2010, from Arkansas Aquaculture: http://www.aragriculture.org/aquaculture.htm

USDA APHIS Veterinary Services \& Maine Department of Marine Resourse \& Maine Aquaculture Association. (2008). Infectious Salmon Anemia Program Standards. Washington D.C.: USDA APHIS Veterinary Services.

Virginia Aquaculture Association (VA AA). (2007-2011). Virginia Aquaculture Association. Retrieved 06 11, 2011, from Virginia Aquaculture Association Website: http://www.virginiaaquaculture.org/

Walker, M. (2003-2004). Serving Alabama Aquaculture. (M. Walker, Ed.) Retrieved 2010 йил 28-July from Alabama Farmers Federation (ALFA): http://www.alfafarmers.org/commodities/catfish.phtml

Whitledge, D., \& Hitchens, P. (n.d.). VHS Surveillance in Illinois. 1-19. Carbondale, Illinois, United States: Fisheries \& Illinois Aquaculture Center. Retrieved 09 07, 2011, from VHS Surveillance in Illinois: http://fishdata.siu.edu/cool10/cool8.pdf

Wirth, F., \& Luzar, E. J. (2000). A scale measure of State Regulatory Climate Toward Finfish Aquaculture. Journal of the World Aquaculture Society, 31(4), 545-557. 


\section{APPENDICES}

\section{FIGURES AND TABLES}

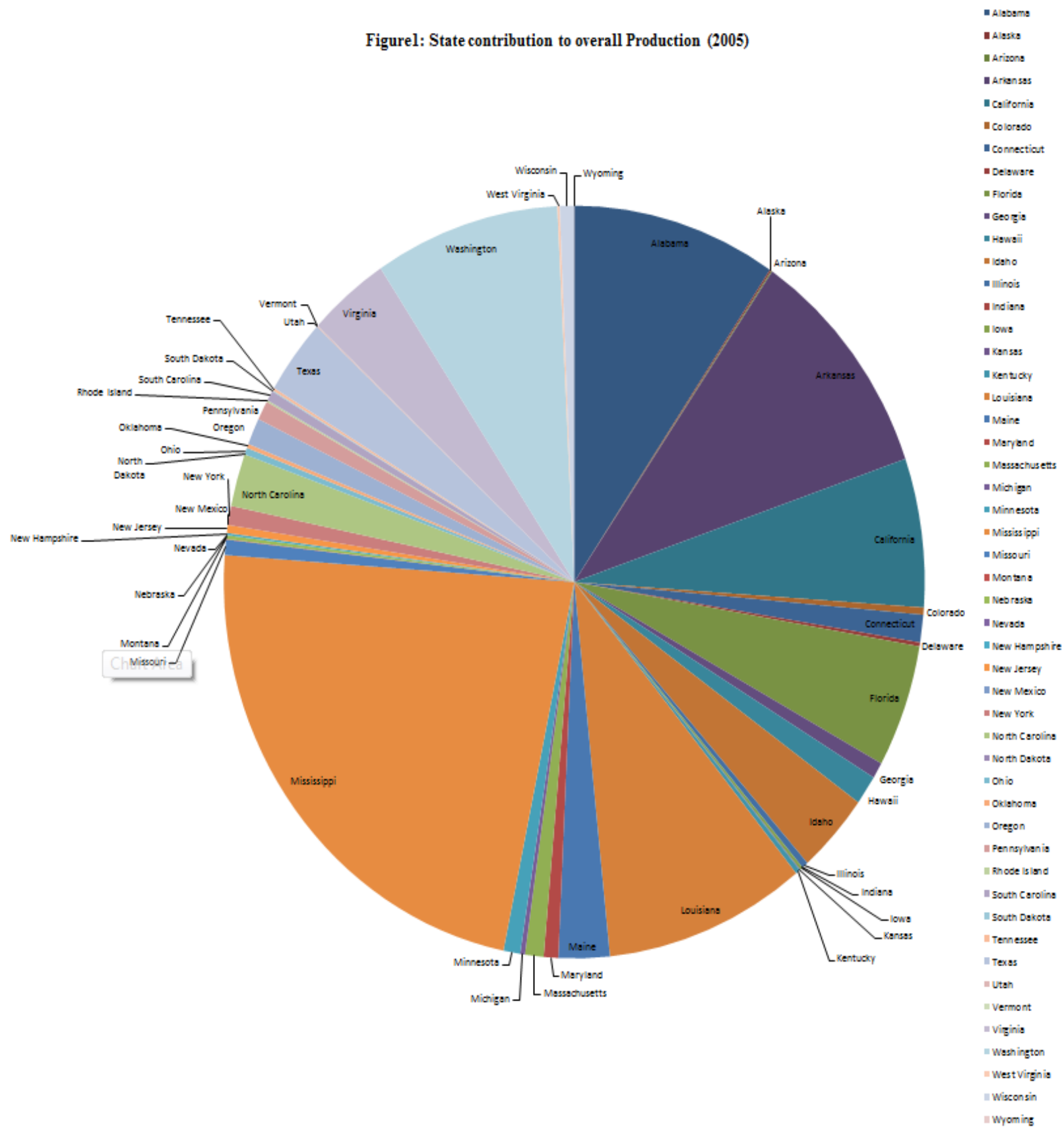

Source- Adapted 2007 NASS Census of Aquaculture

Figure 1: State Contribution to Overall Production (2005)

Source: Adapted NASS Census of Aquaculture Data (2007) 


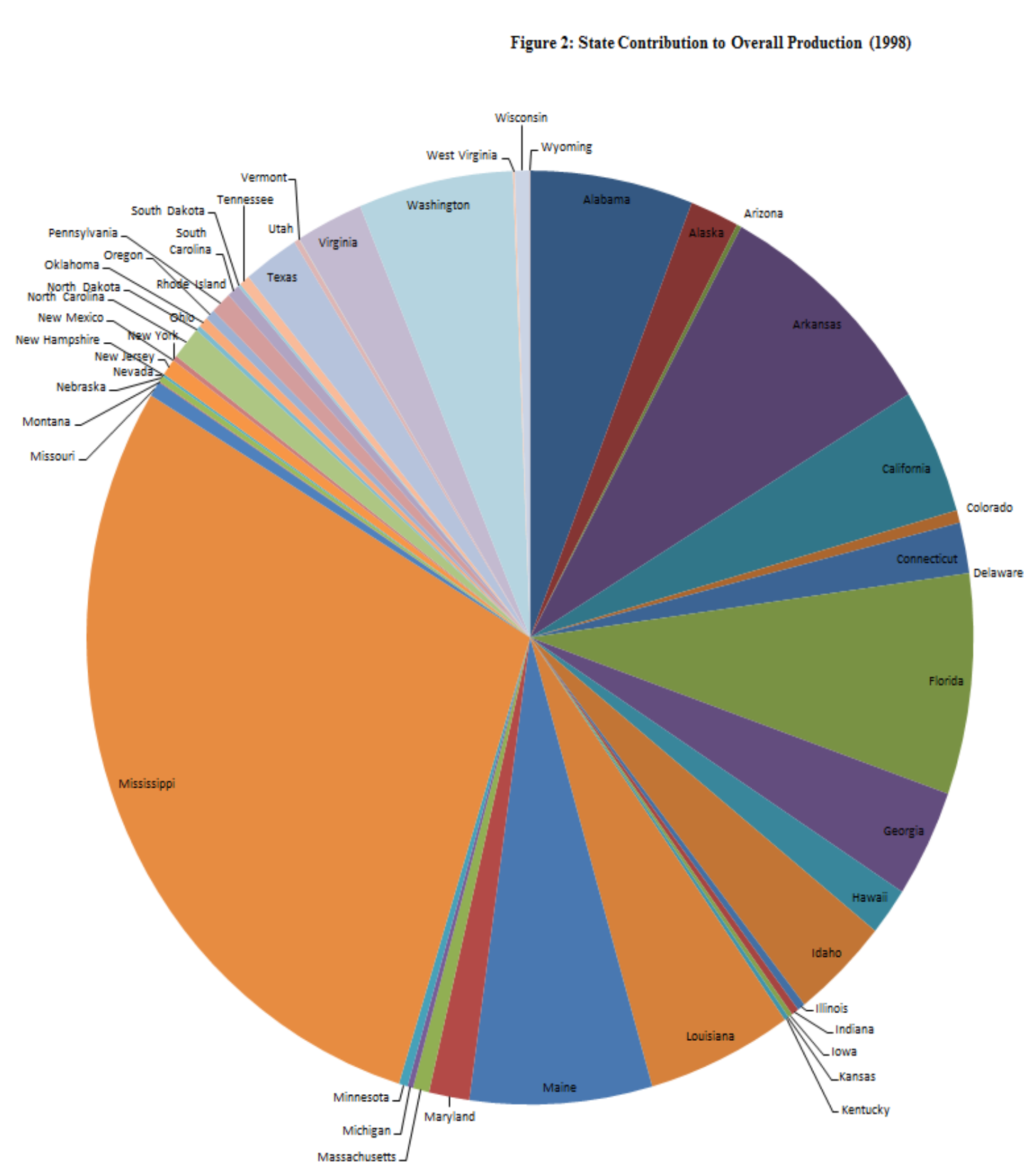

Source: Adapted NASS Census of Aquaculture Data (2007)

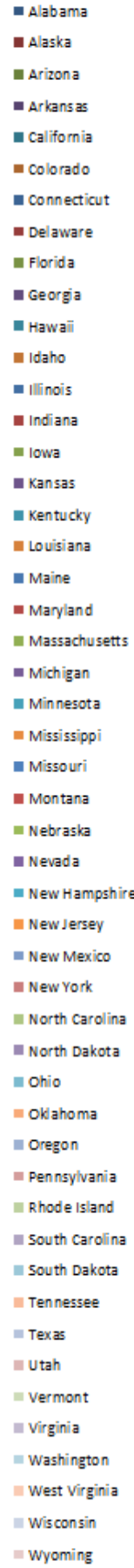

Figure 2: State Contribution to Overall Production (1998)

Source: Adapted NASS Census of Aquaculture Data (2007) 


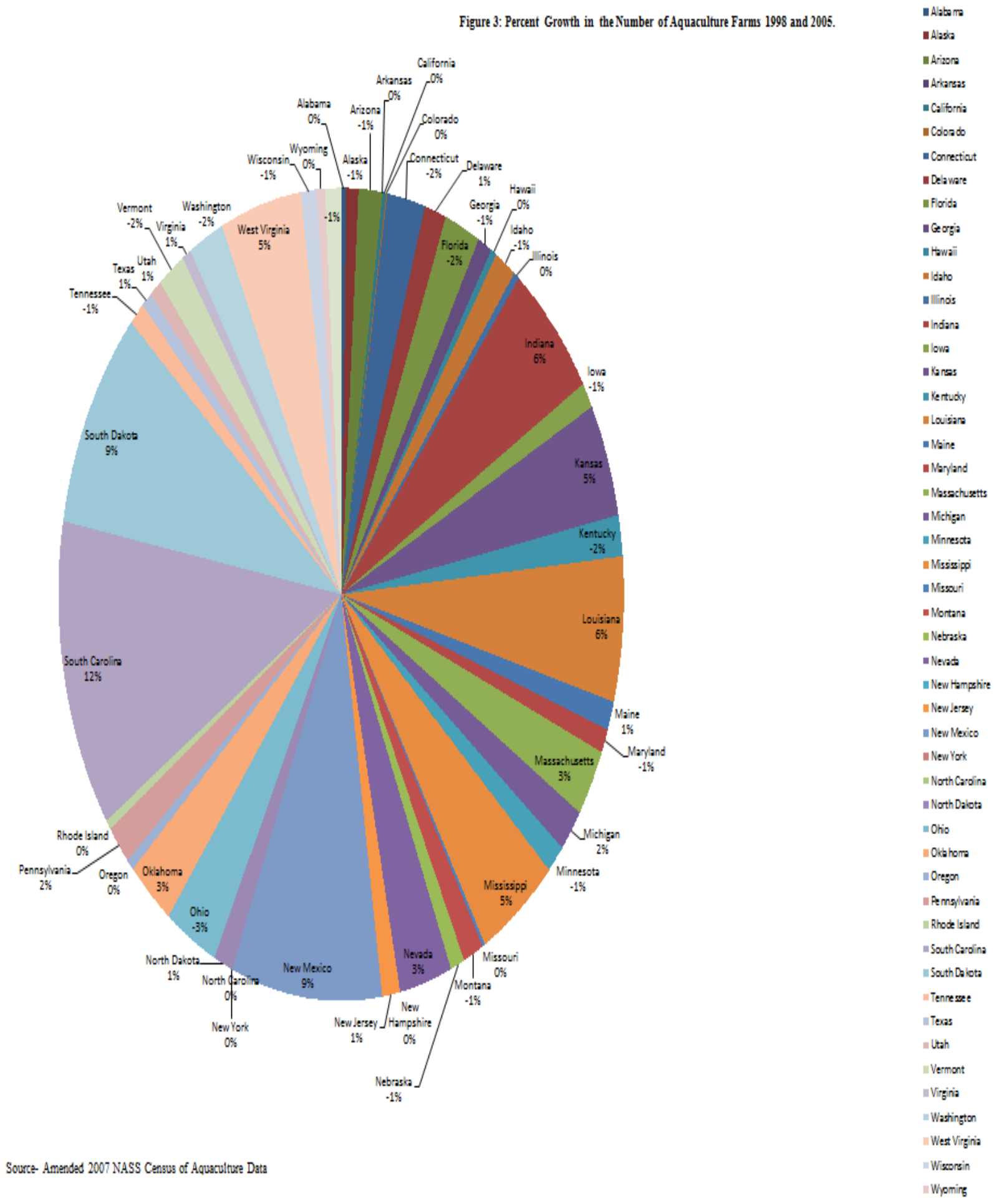

Figure 3: Percent Change in Number of Aquaculture Farms (1998 and 2005) Source: Adapted NASS Census of Aquaculture Data (2007) 


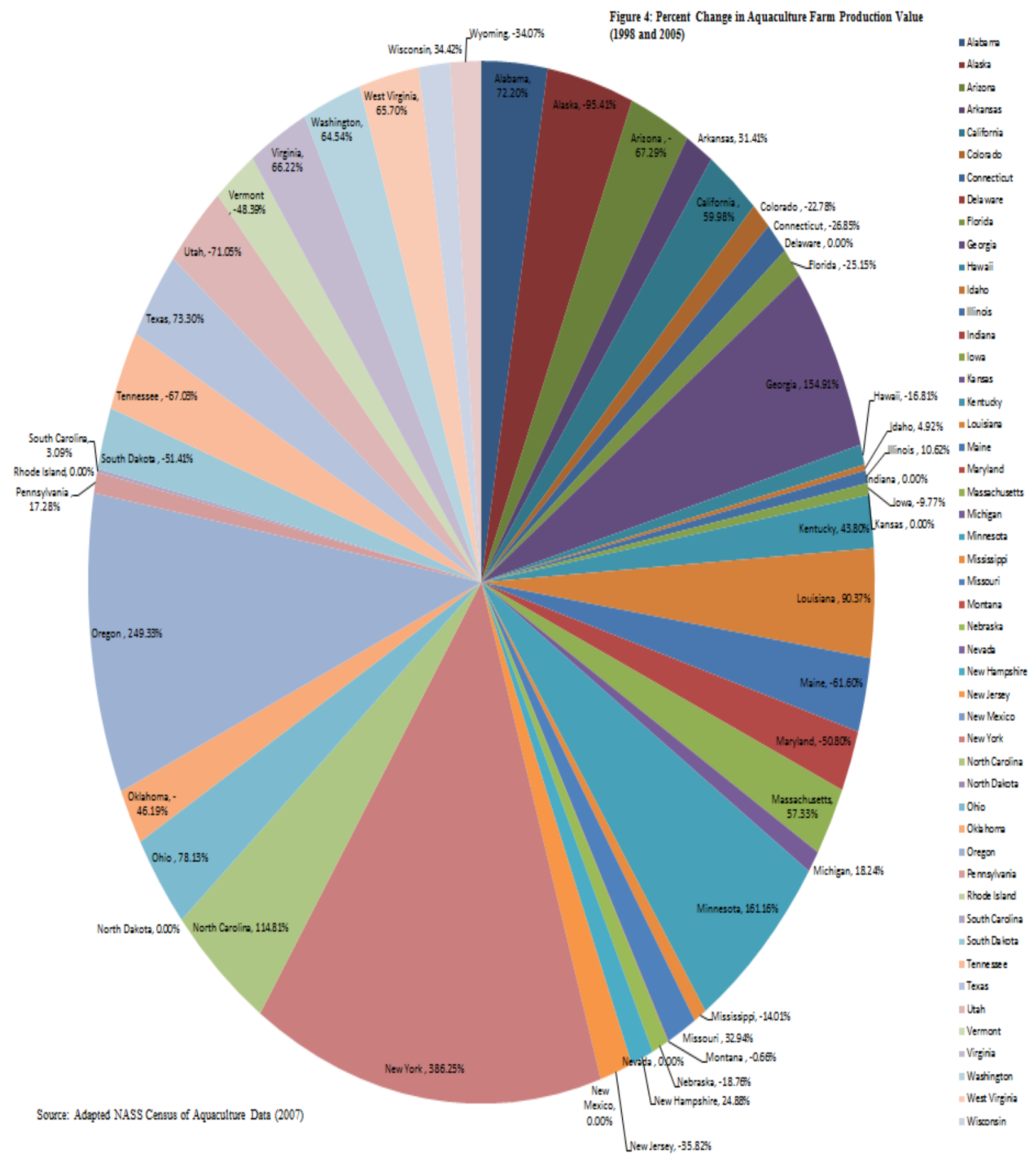

Figure 4: Percent Change in Aquaculture Farm Production Value (1998 and 2005) Source: Adapted NASS Census of Aquaculture Data (2007) 


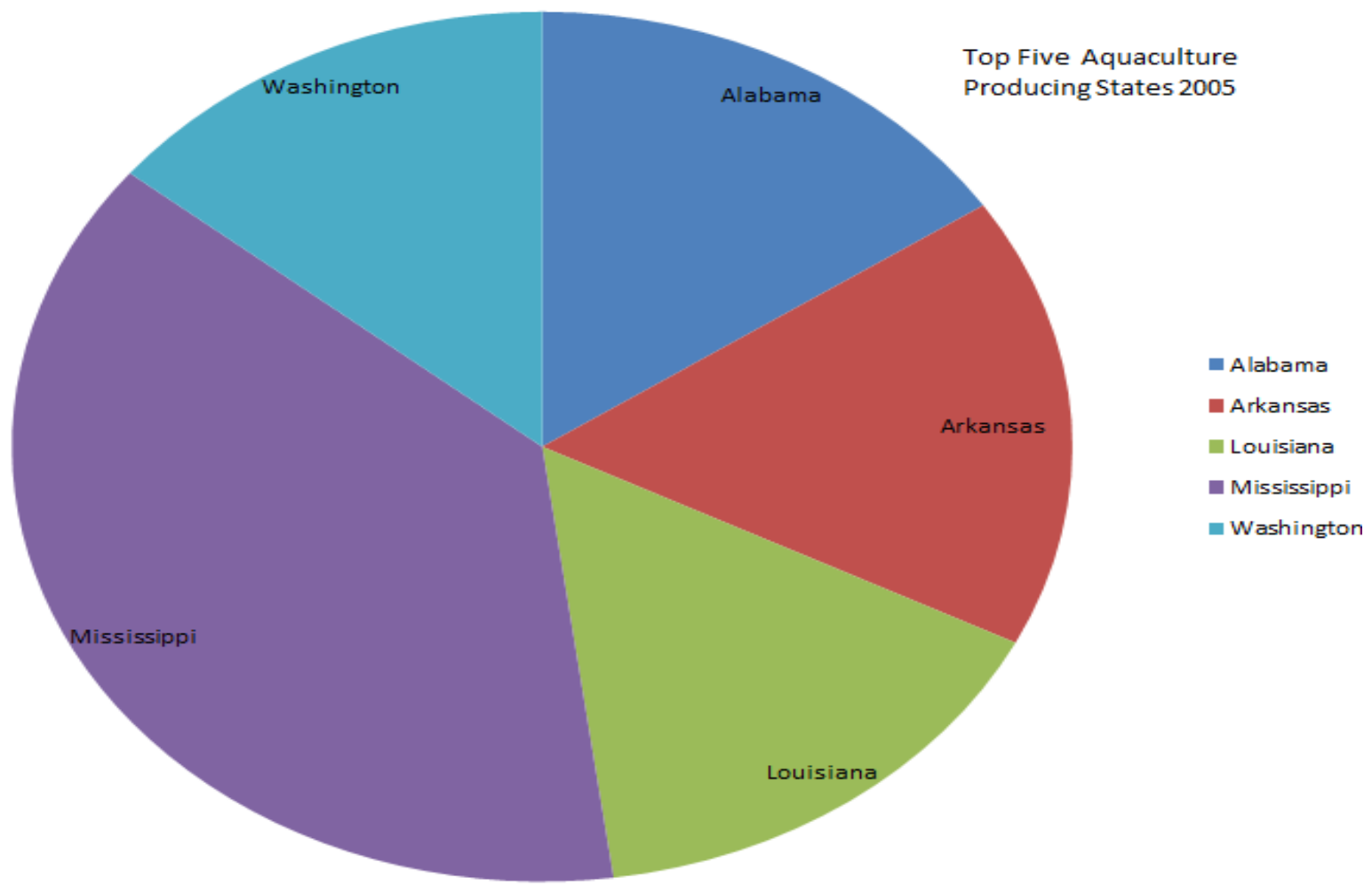

Figure 5: Top Five Aquaculture Producing States in U.S. (2005) Source: Adapted NASS Census of Aquaculture Data (2007)

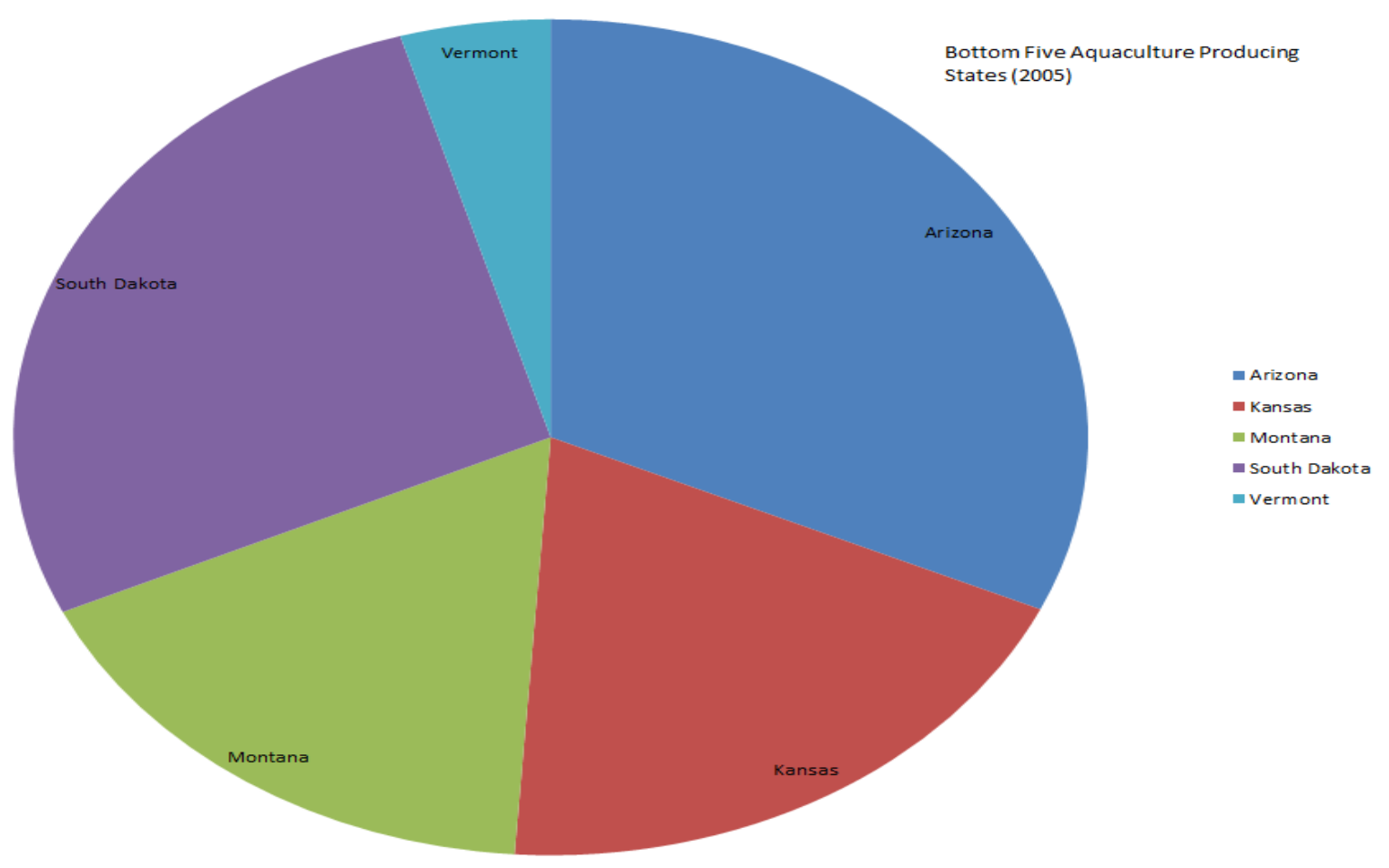

Figure 6: Bottom Five Aquaculture Producing States in U.S. (2005) Source: Adapted NASS Census of Aquaculture Data (2007) 


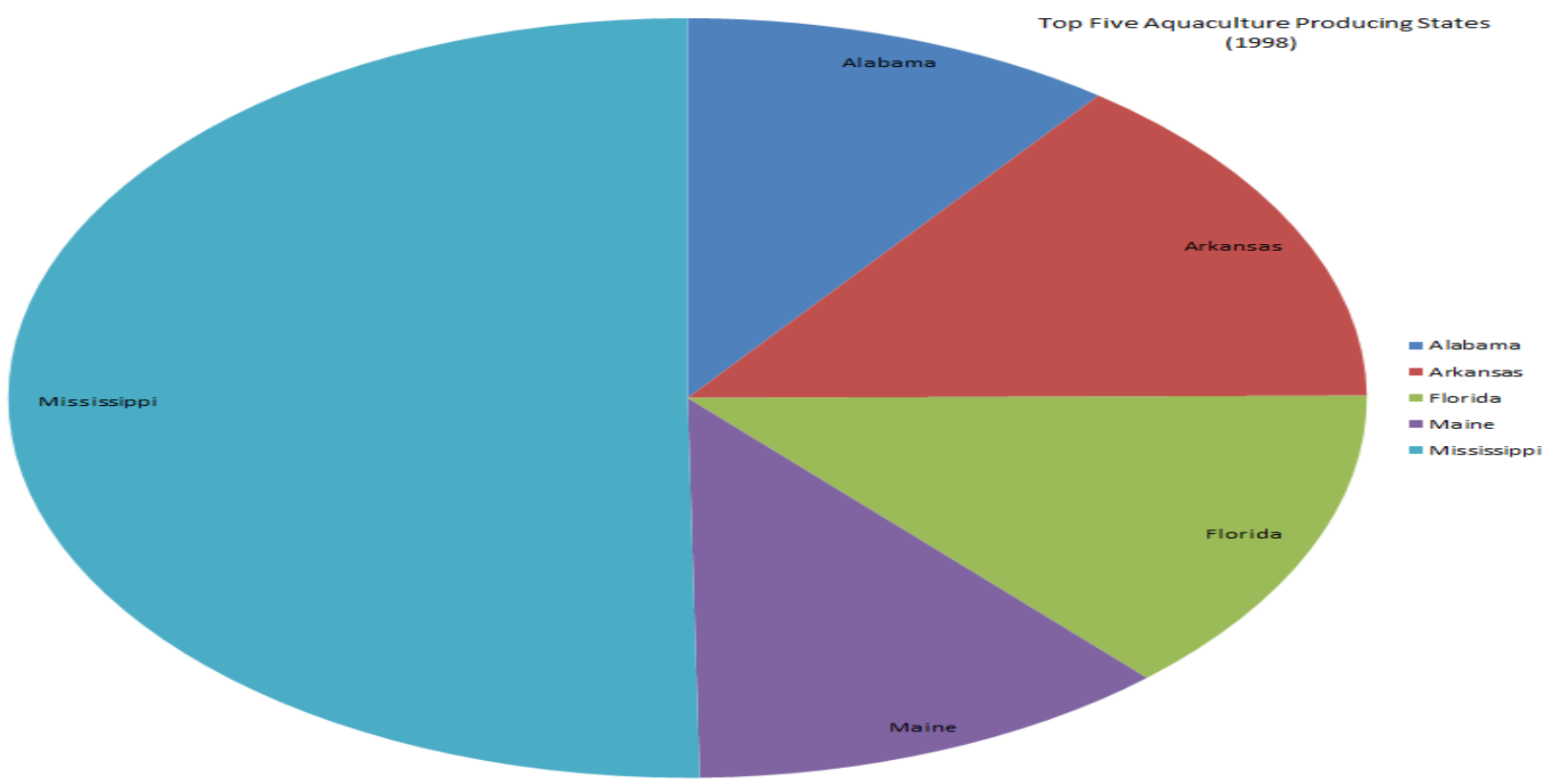

Figure 7: Top Five Aquaculture Producing States in U.S. (1998)

Source: Adapted NASS Census of Aquaculture Data (2007)

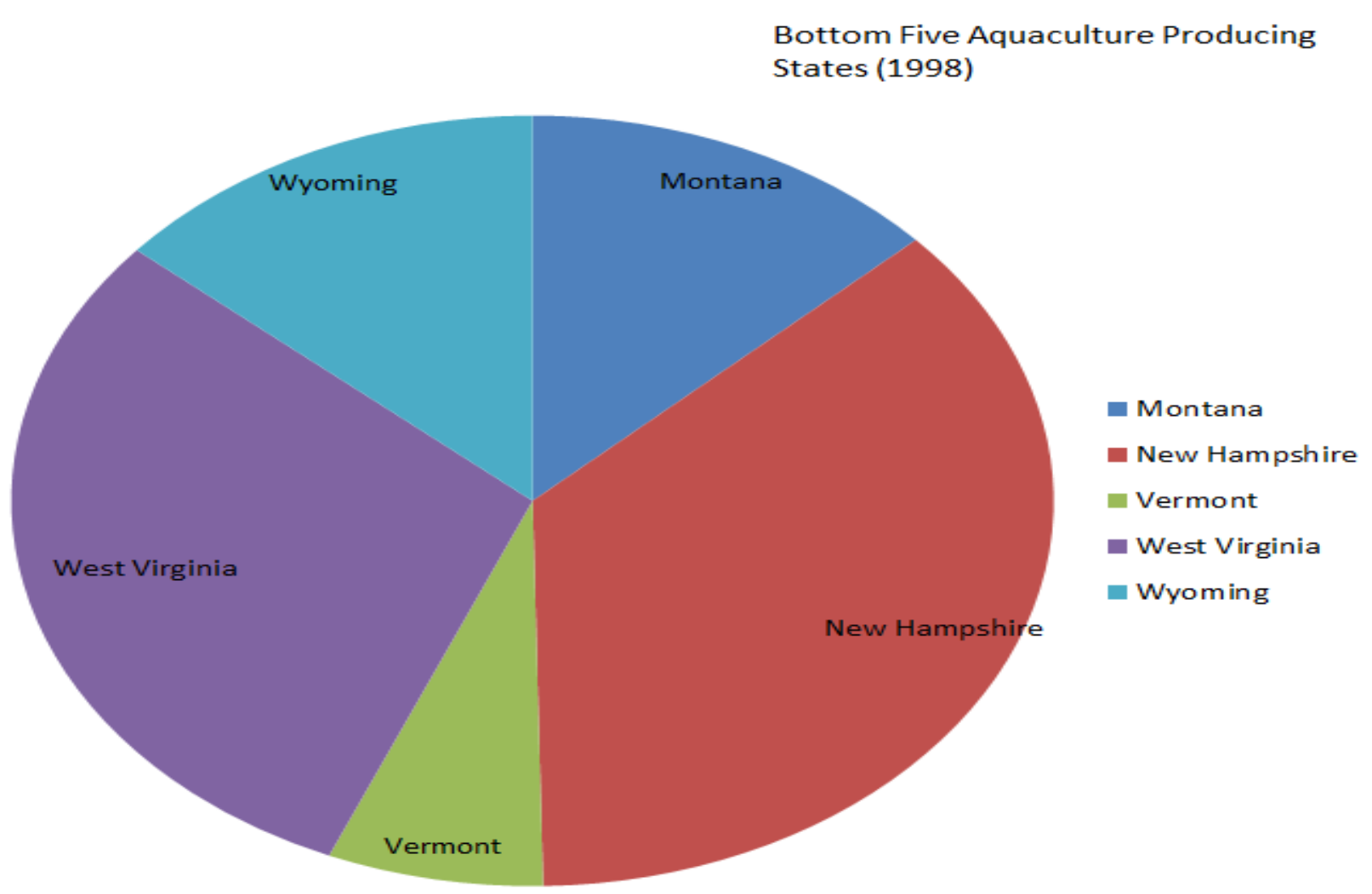

Figure 8: Bottom Five Aquaculture Producing States in U.S. (1998)

Source: Adapted NASS Census of Aquaculture Data (2007) 


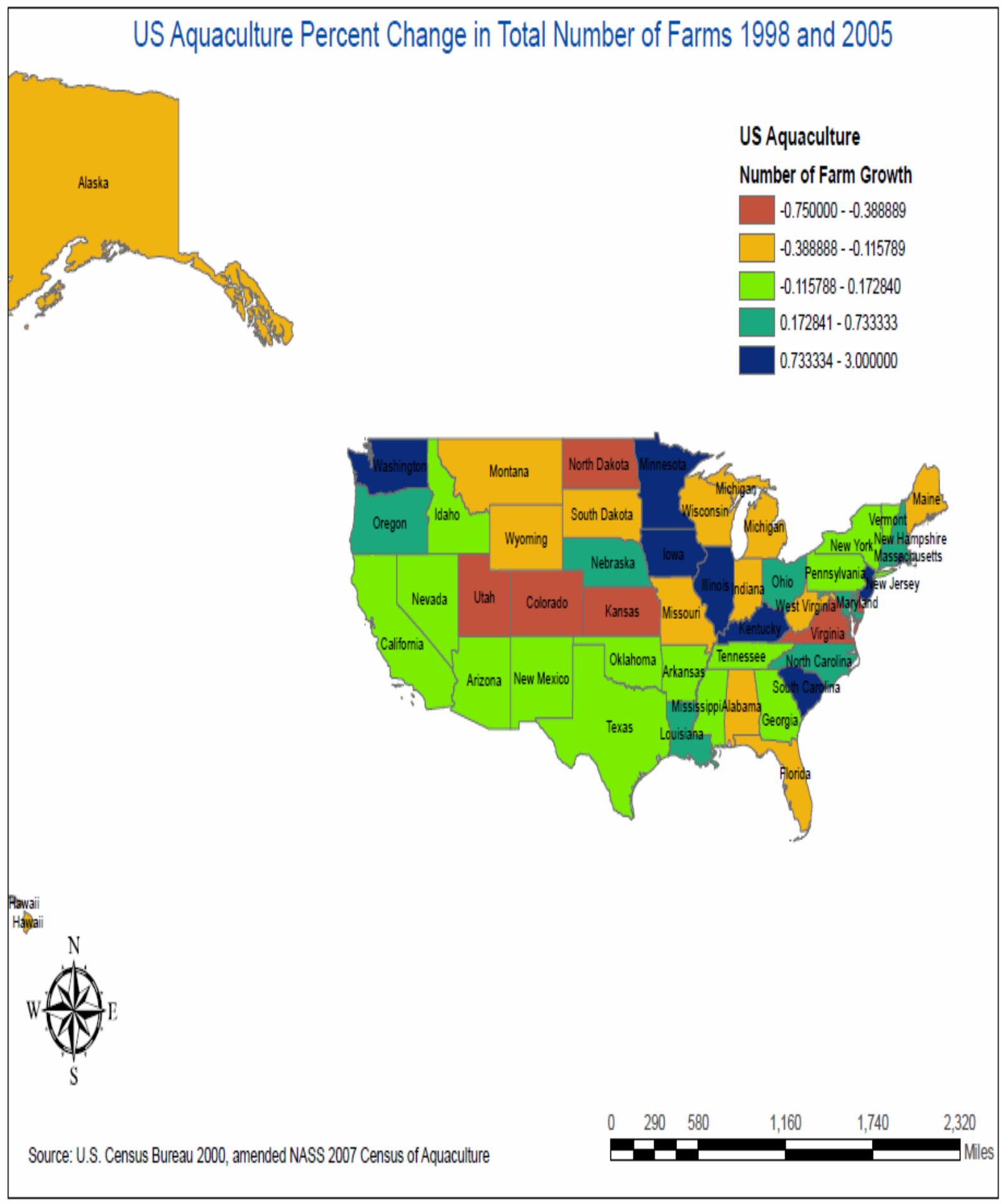

Figure 9: U.S. Aquaculture Percent Change in Total Number of Farms (1998-2005) Source: U.S. Census Bureau and Amended NASS 2005 Census of Aquaculture Data 


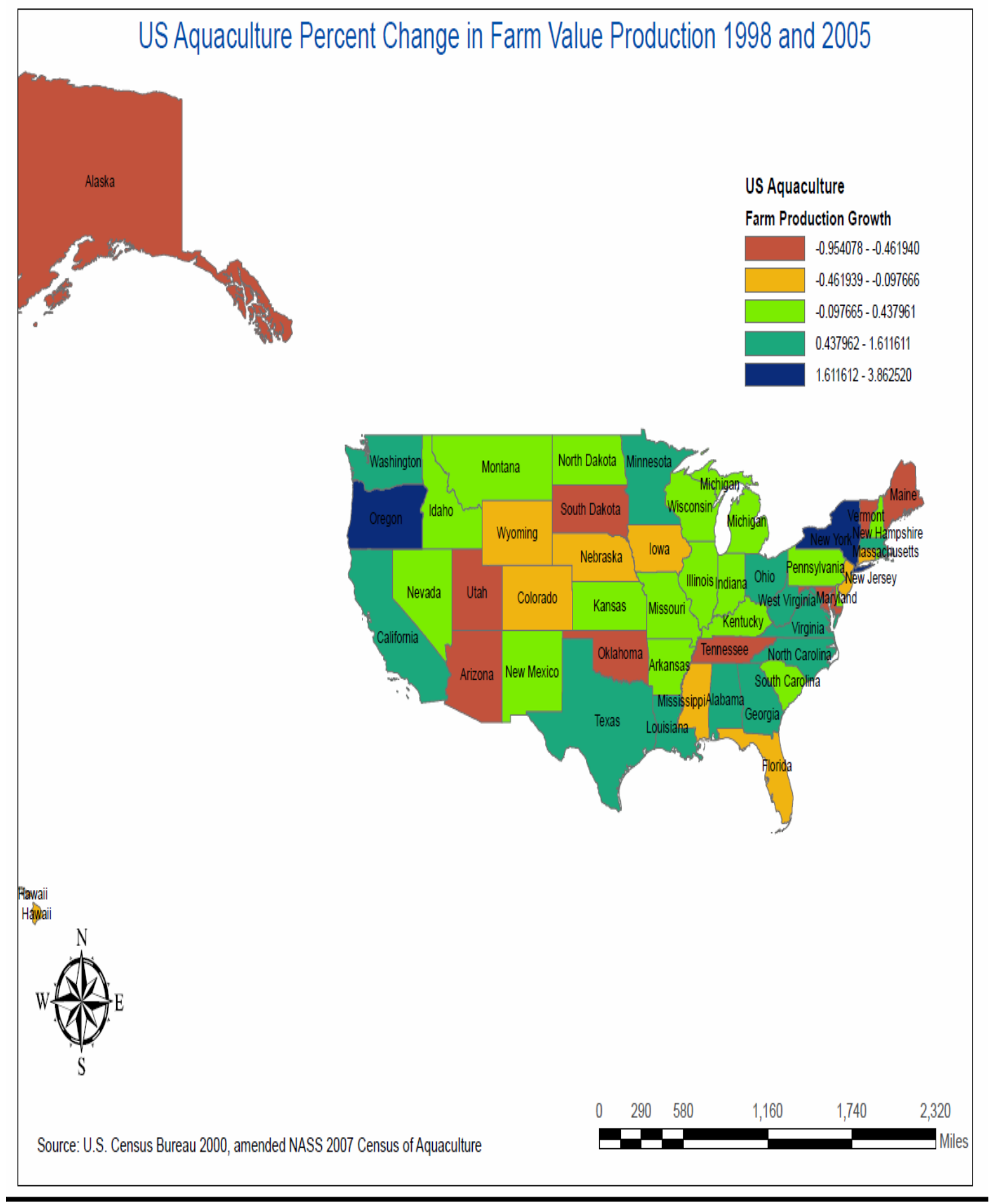

Figure 10: U.S. Aquaculture Farm Value Percent Change in Production Growth (1998-2005) Source: U.S. Census Bureau and Amended NASS 2005 Census of Aquaculture Data 


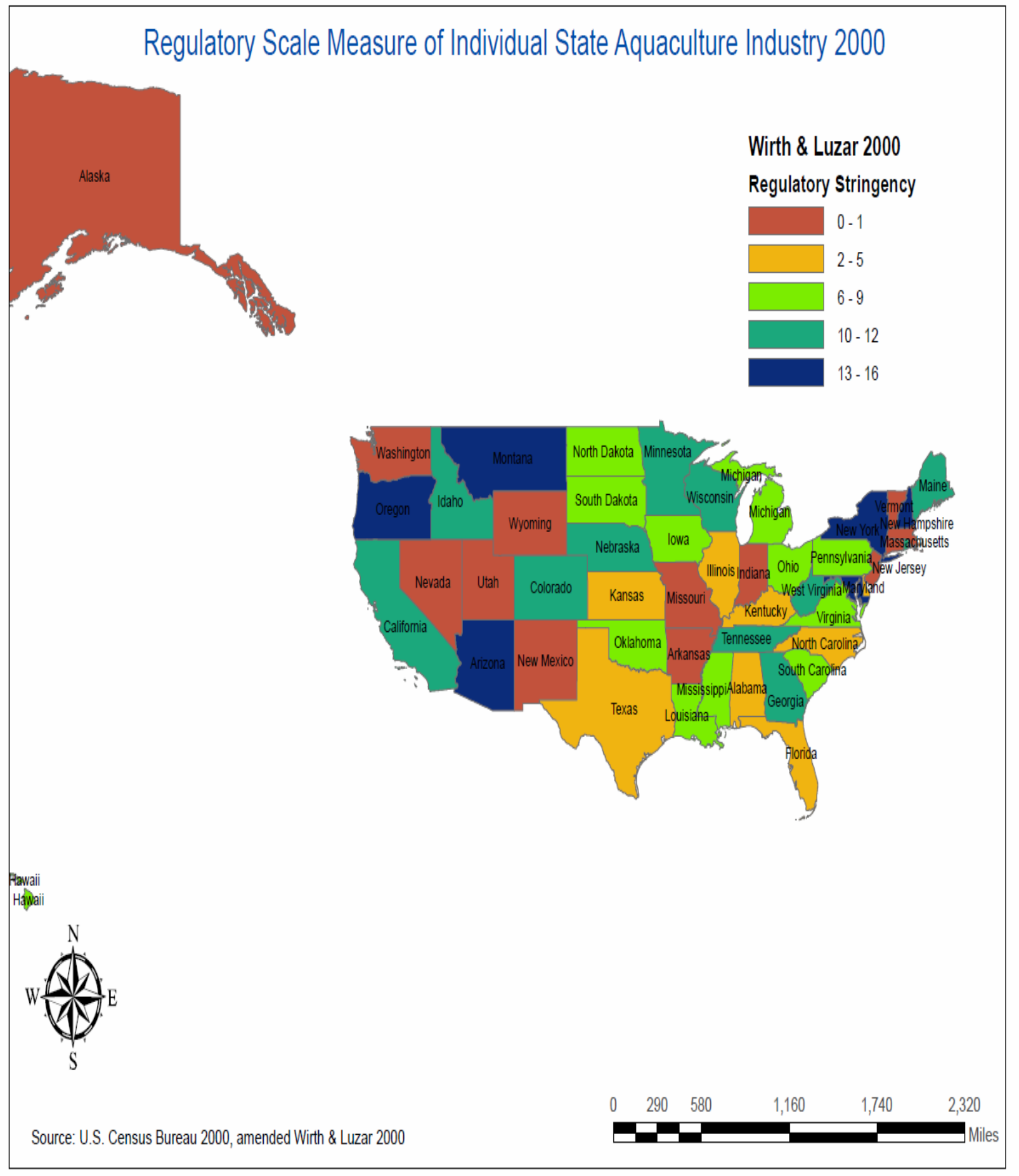

Figure 11: Regulatory Scale Measure of Individual State Aquaculture 200 (Wirth and Luzar) Source: U.S. Census Bureau and Amended Wirth and Luzar 2000 Data 


\begin{tabular}{|c|c|c|c|c|c|c|c|}
\hline & $2005 \#$ \# farms & 2005 Prod. Value & Zatio of State to total US (05 & 1998\# Farms & 1998 Prod. Value & Ratio of State to total US (98) & 1998 - 2005 Change in Prod. \\
\hline United States & 4,309 & $1,092,386$ & & 4,028 & 978,012 & & $-114,374$ \\
\hline Alabama & 215 & 102,796 & 0.094100 & 259 & 59,694 & 0.061036061 & $-43,102$ \\
\hline Alaska & 26 & 826 & 0.000756 & 39 & 17,987 & 0.01839139 & 17,161 \\
\hline Arizona & 11 & 562 & 0.000514 & 11 & 1,718 & 0.001756625 & 1,156 \\
\hline Arkansas & 211 & 110,542 & 0.101193 & 222 & 84,120 & 0.086011215 & $-26,422$ \\
\hline California & 118 & 69,607 & 0.063720 & 120 & 43,509 & 0.044487184 & $-26,098$ \\
\hline Colorado & 15 & 3,349 & 0.003066 & 32 & 4,337 & 0.004434506 & 988 \\
\hline Connecticut & 30 & 12,902 & 0.011811 & 23 & 17,638 & 0.018034544 & 4,736 \\
\hline Delaware & 3 & 1,870 & 0.001712 & 6 & (D) & N/A & $\mathrm{N} / \mathrm{A}$ \\
\hline Florida & 359 & 57,406 & 0.052551 & 449 & 76,696 & 0.078420306 & 19,290 \\
\hline Georgia & 79 & 7,502 & 0.006868 & 73 & 2,943 & 0.038372275 & $-4,559$ \\
\hline Hawaii & 59 & 13,761 & 0.012597 & 85 & 16,541 & 0.01691288 & 2,780 \\
\hline Idaho & 35 & 37,685 & 0.034498 & 38 & 35,919 & 0.036726543 & $-1,766$ \\
\hline Illinois & 47 & 3,176 & 0.002907 & 20 & 2,871 & 0.002935547 & -305 \\
\hline Indiana & 18 & (D) & N/A & 24 & 2,678 & 0.002738208 & $\mathrm{~N} / \mathrm{A}$ \\
\hline lowa & 21 & 1,469 & 0.001345 & 10 & 1,628 & 0.001664601 & 159 \\
\hline Kansas & 12 & 342 & 0.000313 & 20 & (D) & N/A & $\mathrm{N} / \mathrm{A}$ \\
\hline Kentucky & 65 & 2,341 & 0.002143 & 27 & 1,628 & 0.001664601 & -713 \\
\hline Louisiana & 873 & 101,314 & 0.092746 & 683 & 53,220 & 0.05441651 & $-48,094$ \\
\hline Maine & 50 & 25,580 & 0.023417 & 65 & 66,610 & 0.068107549 & 41,030 \\
\hline Maryland & 86 & 7,292 & 0.006675 & 52 & 14,822 & 0.015155233 & 7,530 \\
\hline Massachusetts & 157 & 9,342 & 0.008552 & 111 & 5,938 & 0.0060715 & $-3,404$ \\
\hline Michigan & 34 & 2,398 & 0.002195 & 47 & 2,028 & 0.002073594 & -370 \\
\hline Minnesota & 77 & 8,412 & 0.007701 & 36 & 3,221 & 0.003293416 & $-5,191$ \\
\hline Mississippi & 403 & 249,704 & 0.228586 & 419 & 290,382 & 0.296910467 & 40,678 \\
\hline Missouri & 35 & 7,144 & 0.006540 & 49 & 5,374 & 0.00549482 & $-1,770$ \\
\hline Montana & 8 & 302 & 0.000276 & 10 & 304 & 0.000310835 & 2 \\
\hline Nebraska & 26 & 1,750 & 0.001602 & 15 & 2,154 & 0.002202427 & 404 \\
\hline Nevada & - & - & N/A & 2 & (D) & N/A & $\mathrm{N} / \mathrm{A}$ \\
\hline New Hampshire & 10 & 1,054 & 0.000965 & 8 & 844 & 0.000862975 & -210 \\
\hline New Jersey & 87 & 3,714 & 0.003400 & 28 & 5,787 & 0.005917105 & 2,073 \\
\hline New Mexico & 3 & (D) & N/A & 3 & (D) & N/A & $\mathrm{N} / \mathrm{A}$ \\
\hline New York & 54 & 8,913 & 0.008159 & 54 & 1,833 & 0.00187421 & $-7,080$ \\
\hline North Carolina & 186 & 24,725 & 0.022634 & 147 & 11,510 & 0.011768772 & $-13,215$ \\
\hline North Dakota & 1 & (D) & N/.A & 4 & (D) & N/A & $\mathrm{N} / \mathrm{A}$ \\
\hline Ohio & 55 & 3,185 & 0.002916 & 33 & 1,788 & 0.001828198 & $-1,397$ \\
\hline Oklahoma & 20 & 1,958 & 0.001792 & 18 & 3,639 & 0.003720813 & 1,681 \\
\hline Oregon & 47 & 12,478 & 0.011423 & 34 & 3,572 & 0.003652307 & $-8,906$ \\
\hline Pennsylvania & 56 & 8,951 & 0.008194 & 51 & 7,632 & 0.007803585 & $-1,319$ \\
\hline Rhode Island & 12 & 840 & 0.000769 & 3 & (D) & N/A & $\mathrm{N} / \mathrm{A}$ \\
\hline South Carolina & 85 & 4,773 & 0.004369 & 27 & 4,630 & 0.004734093 & -143 \\
\hline South Dakota & 7 & 484 & 0.000443 & 9 & 996 & 0.001018392 & 512 \\
\hline Tennessee & 45 & 1,286 & 0.001177 & 39 & 3,901 & 0.003988704 & 2,615 \\
\hline Texas & 95 & 35,359 & 0.032369 & 81 & 20,403 & 0.020861707 & $-14,956$ \\
\hline Utah & 11 & 559 & 0.000512 & 18 & 1,931 & 0.001974413 & 1,372 \\
\hline Vermont & 9 & 80 & 0.000073 & 8 & 155 & 0.000158485 & 75 \\
\hline Virginia & 147 & 40,939 & 0.037477 & 294 & 24,629 & 0.025182718 & $-16,310$ \\
\hline Washington & 194 & 93,203 & 0.085321 & 91 & 56,646 & 0.057919535 & $-36,557$ \\
\hline West Virginia & 21 & 1,145 & 0.001048 & 27 & 691 & 0.000706535 & -454 \\
\hline Wisconsin & 84 & 7,025 & 0.006431 & 95 & 5,226 & 0.005343493 & $-1,799$ \\
\hline Wyoming & 7 & 209 & 0.000191 & 9 & 317 & 0.000324127 & 108 \\
\hline
\end{tabular}

Table 1: Individual State Contribution Dataset (1998-2005)

Source: Amended 2007 Census of Aquaculture Data 


\begin{tabular}{|c|c|c|c|c|c|c|}
\hline & $2005 \#$ farms & 2005 Prod. Value & 1998 \# Farms & 1998 Prod. Value & \# Of Farms growth (Percentage) & |\# Percentage production growth between (1998-2005) \\
\hline United States & 4,309 & $1,092,386$ & 4,028 & 978,012 & $6.98 \%$ & $11.69 \%$ \\
\hline Alabama & 215 & 102,796 & 259 & 59,694 & $-16.99 \%$ & $72.20 \%$ \\
\hline Alaska & 26 & 826 & 39 & 17,987 & $-33.33 \%$ & $-95.41 \%$ \\
\hline Arizona & 11 & 562 & 11 & 1,718 & $0.00 \%$ & $-67.29 \%$ \\
\hline Arkansas & 211 & 110,542 & 222 & 84,120 & $-4.95 \%$ & $31.41 \%$ \\
\hline California & 118 & 69,607 & 120 & 43,509 & $-1.67 \%$ & $59.98 \%$ \\
\hline Colorado & 15 & 3,349 & 32 & 4,337 & $-53.13 \%$ & $-22.78 \%$ \\
\hline Connecticut & 30 & 12,902 & 23 & 17,638 & $30.43 \%$ & $-26.85 \%$ \\
\hline Delaware & 3 & 1,870 & 6 & (D) & $-50.00 \%$ & $0.00 \%$ \\
\hline Florida & 359 & 57,406 & 449 & 76,696 & $-20.04 \%$ & $-25.15 \%$ \\
\hline Georgia & 79 & 7,502 & 73 & 2,943 & $8.22 \%$ & $154.91 \%$ \\
\hline Hawaii & 59 & 13,761 & 85 & 16,541 & $-30.59 \%$ & $-16.81 \%$ \\
\hline Idaho & 35 & 37,685 & 38 & 35,919 & $-7.89 \%$ & $4.92 \%$ \\
\hline Illinois & 47 & 3,176 & 20 & 2,871 & $135.00 \%$ & $10.62 \%$ \\
\hline Indiana & 18 & (D) & 24 & 2,678 & $-25.00 \%$ & $0.00 \%$ \\
\hline lowa & 21 & 1,469 & 10 & 1,628 & $110.00 \%$ & $-9.77 \%$ \\
\hline Kansas & 12 & 342 & 20 & (D) & $-40.00 \%$ & $0.00 \%$ \\
\hline Kentucky & 65 & 2,341 & 27 & 1,628 & $140.74 \%$ & $43.80 \%$ \\
\hline Louisiana & 873 & 101,314 & 683 & 53,220 & $27.82 \%$ & $90.37 \%$ \\
\hline Maine & 50 & 25,580 & 65 & 66,610 & $-23.08 \%$ & $-61.60 \%$ \\
\hline Maryland & 86 & 7,292 & 52 & 14,822 & $65.38 \%$ & $-50.80 \%$ \\
\hline Massachusetts & 157 & 9,342 & 111 & 5,938 & $41.44 \%$ & $57.33 \%$ \\
\hline Michigan & 34 & 2,398 & 47 & 2,028 & $-27.66 \%$ & $18.24 \%$ \\
\hline Minnesota & 77 & 8,412 & 36 & 3,221 & $113.89 \%$ & $161.16 \%$ \\
\hline Mississippi & 403 & 249,704 & 419 & 290,382 & $-3.82 \%$ & $-14.01 \%$ \\
\hline Missouri & 35 & 7,144 & 49 & 5,374 & $-28.57 \%$ & $32.94 \%$ \\
\hline Montana & 8 & 302 & 10 & 304 & $-20.00 \%$ & $-0.66 \%$ \\
\hline Nebraska & 26 & 1,750 & 15 & 2,154 & $73.33 \%$ & $-18.76 \%$ \\
\hline Nevada & $\cdot$ & $\cdot$ & 2 & (D) & $0.00 \%$ & $0.00 \%$ \\
\hline New Hampshire & 10 & 1,054 & 8 & 844 & $25.00 \%$ & $24.88 \%$ \\
\hline New Jersey & 87 & 3,714 & 28 & 5,787 & $210.71 \%$ & $-35.82 \%$ \\
\hline New Mexico & 3 & (D) & 3 & (D) & $0.00 \%$ & $0.00 \%$ \\
\hline New York & 54 & 8,913 & 54 & 1,833 & $0.00 \%$ & $386.25 \%$ \\
\hline North Carolina & 186 & 24,725 & 147 & 11,510 & $26.53 \%$ & $114.81 \%$ \\
\hline North Dakota & 1 & (D) & 4 & (D) & $-75.00 \%$ & $0.00 \%$ \\
\hline Ohio & 55 & 3,185 & 33 & 1,788 & $66.67 \%$ & $78.13 \%$ \\
\hline Oklahoma & 20 & 1,958 & 18 & 3,639 & $11.11 \%$ & $-46.19 \%$ \\
\hline Oregon & 47 & 12,478 & 34 & 3,572 & $38.24 \%$ & $249.33 \%$ \\
\hline Pennsylvania & 56 & 8,951 & 51 & 7,632 & $9.80 \%$ & $17.28 \%$ \\
\hline Rhode Island & 12 & 840 & 3 & (D) & $300.00 \%$ & $0.00 \%$ \\
\hline South Carolina & 85 & 4,773 & 27 & 4,630 & $214.81 \%$ & $3.09 \%$ \\
\hline South Dakota & 7 & 484 & 9 & 996 & $-22.22 \%$ & $-51.41 \%$ \\
\hline Tennessee & 45 & 1,286 & 39 & 3,901 & $15.38 \%$ & $-67.03 \%$ \\
\hline Texas & 95 & 35,359 & 81 & 20,403 & $17.28 \%$ & $73.30 \%$ \\
\hline Utah & 11 & 559 & 18 & 1,931 & $-38.89 \%$ & $.71 .05 \%$ \\
\hline Vermont & 9 & 80 & 8 & 155 & $12.50 \%$ & $-48.39 \%$ \\
\hline Virginia & 147 & 40,939 & 294 & 24,629 & $-50.00 \%$ & $66.22 \%$ \\
\hline Washington & 194 & 93,203 & 91 & 56,646 & $113.19 \%$ & $64.54 \%$ \\
\hline West Virginia & 21 & 1,145 & 27 & 691 & $-22.22 \%$ & $65.70 \%$ \\
\hline Wisconsin & 84 & 7,025 & 95 & 5,226 & $-11.58 \%$ & $34.42 \%$ \\
\hline Wyoming & 7 & 209 & 9 & 317 & $-22.22 \%$ & $-34.07 \%$ \\
\hline Average & & & & & $23.57 \%$ & $23.04 \%$ \\
\hline
\end{tabular}

Table 2: Aquaculture Value Per Farm (1998-2005)

Source: Amended NASS 2007 Census of Aquaculture 


\begin{tabular}{|c|c|c|c|c|c|c|c|}
\hline & 2005 \# farms & 2005 Prod. Value & Ratio of State to total US (05) & 1998 \# Farms & 1998 Prod. Value & Ratio of State to total US (98) & $\begin{array}{c}1998-2005 \text { Change in } \\
\text { Prod. }\end{array}$ \\
\hline United States & 4,309 & $1,092,386$ & & 4,028 & 978,012 & & $-114,374$ \\
\hline Alabama & 215 & 102,796 & 0.094100 & 259 & 59,694 & 0.061036061 & $-43,102$ \\
\hline Arkansas & 211 & 110,542 & 0.101193 & 222 & 84,120 & 0.086011215 & $-26,422$ \\
\hline Louisiana & 873 & 101,314 & 0.092746 & 683 & 53,220 & 0.05441651 & $-48,094$ \\
\hline Mississippi & 403 & 249,704 & 0.228586 & 419 & 290,382 & 0.296910467 & 40,678 \\
\hline Washington & 194 & 93,203 & 0.085321 & 91 & 56,646 & 0.057919535 & $-36,557$ \\
\hline
\end{tabular}

Table 3: Top 5 Aquaculture Producing States in U.S. Dataset (2005)

Source: Amended 2007 NASS Census of Aquaculture

\begin{tabular}{c|c|c|c|c|c|c|c} 
& $2005 \#$ farms & 2005 Prod. Value & atio of State to total US (0) & 1998\#Farms & 1998 Prod. Value & Ratio of State to total US (98) & 1998- 2005 Change in Prod. \\
\hline United States & 4,309 & $1,092,386$ & & 4,028 & 978,012 & & $.114,374$ \\
\hline Arizona & 11 & 562 & 0.000514 & 11 & 1,718 & 0.001756625 & 1,156 \\
\hline Kannas & 12 & 342 & 0.000313 & 20 & $(D)$ & \#VALLE! & \#VALLE! \\
\hline Montana & 8 & 302 & 0.000276 & 10 & 304 & 0.000310835 & 2 \\
\hline South Dakota & 7 & 484 & 0.000443 & 9 & 996 & 0.001018392 & 512 \\
\hline Vermont & 9 & 80 & 0.000073 & 8 & 155 & 0.000158485 & 75
\end{tabular}

Table 4: Bottom 5 Aquaculture Producing States in U.S. Dataset (2005)

Source: Amended 2007 NASS Census of Aquaculture

\begin{tabular}{|c|c|c|c|c|c|c|c|}
\hline & $2005 \#$ farms & 2005 Prod. Value & Ratio of State to total US (05) & 1998\#Farms & 1998 Prod. Value & Ratio of State to total US (98) & 1998-2005 Change in Prod. \\
\hline United States & 4,309 & $1,092,386$ & & 4,028 & 978,012 & & . 114,374 \\
\hline Alabama & 215 & 102,796 & 0.094100 & 259 & 59,694 & 0.061036061 & $-43,102$ \\
\hline Arkansas & 211 & 110,542 & 0.101193 & 222 & 84,120 & 0.086011215 & $-26,422$ \\
\hline Florida & 359 & 57,406 & 0.052551 & 449 & 76,696 & 0.078420306 & 19,290 \\
\hline Maine & 50 & 25,580 & 0.023417 & 65 & 66,610 & 0.068107549 & 41,030 \\
\hline Mississsippi & 403 & 249,704 & 0.228586 & 419 & 290,382 & 0.296910467 & 40,678 \\
\hline
\end{tabular}

Table 5: Top 5 Aquaculture Producing States in U.S. Dataset (1998)

Source: Amended 2007 NASS Census of Aquaculture

\begin{tabular}{|c|c|c|c|c|c|c|c|}
\hline & $2005 \#$ farms & 2005 Prod. Value & atio of State to total US (05) & $1998 \#$ Farms & 1998 Prod. Value & Ratio of State to total US (98) & 1998 - 2005 Change in Prod, \\
\hline United States & 4,309 & $1,092,386$ & & 4,028 & 978,012 & & $-114,374$ \\
\hline Montana & 8 & 302 & 0,000276 & 10 & 304 & 0,000310835 & 2 \\
\hline New Hampshire & 10 & 1,054 & 0,000965 & 8 & 844 & 0,000862975 & .210 \\
\hline Vermont & 9 & 80 & 0.000073 & 8 & 155 & 0,000158485 & 75 \\
\hline West Virginia & 21 & 1,145 & 0,001048 & 27 & 691 & 0,000706535 & -454 \\
\hline Wyoming & 7 & 209 & 0.000191 & 9 & 317 & 0,000324127 & 108 \\
\hline
\end{tabular}

Table 6: Bottom 5 Aquaculture Producing States in U.S. Dataset (1998)

Source: Amended 2007 NASS Census of Aquaculture 


\begin{tabular}{|c|c|}
\hline Statistics (Growth in \# of Farms): & \\
\hline Number of states with positive growth (1998-2005): & 23 \\
\hline Number of states with negative growth(1998-2005): & 23 \\
\hline Number of states with no growth (1998-2005): & 3 \\
\hline Nevada has not data & 1 \\
\hline Total \# of States: & 50 \\
\hline Average Farm growth & $24 \%$ \\
\hline
\end{tabular}

Table 7: Percent Growth in Aquaculture Producing Farms (1998-2005)

Source: Amended 2007 NASS Census of Aquaculture

\begin{tabular}{|c|c|}
\hline Statistics (growth in Production Value) & \\
\hline Number of states with positive growth (1998-2005): & 24 \\
\hline Number of states with negative growth(1998-2005): & 19 \\
\hline Number of states with no growth (1998-2005): & 0 \\
\hline States with no data & 7 \\
\hline Total \# of States: & 50 \\
\hline Average Production growth & $23 \%$ \\
\hline
\end{tabular}

Table 8: Percent Growth in Production Value for U.S. Aquaculture (1998-2005) Source: Amended 2007 NASS Census of Aquaculture 


\begin{tabular}{|c|c|c|c|c|c|c|}
\hline States & 2005 \# farms & 2005 Prod. Value & 1998 \# Farms & $\begin{array}{l}1998 \\
\text { Prod. } \\
\text { Value }\end{array}$ & $\begin{array}{c}\text { \# Of Farms growth } \\
\text { (Percentage) }\end{array}$ & $\begin{array}{l}\text { \# Percentage } \\
\text { production growth } \\
\text { between (1998- } \\
2005)\end{array}$ \\
\hline United States & 4,309 & $1,092,386$ & 4,028 & 978,012 & $6.98 \%$ & $11.69 \%$ \\
\hline Alabama & 215 & 102,796 & 259 & 59,694 & $-16.99 \%$ & $72.20 \%$ \\
\hline Alaska & 26 & 826 & 39 & 17,987 & $-33.33 \%$ & $-95.41 \%$ \\
\hline Arizona & 11 & 562 & 11 & 1,718 & $0.00 \%$ & $-67.29 \%$ \\
\hline Arkansas & 211 & 110,542 & 222 & 84,120 & $-4.95 \%$ & $31.41 \%$ \\
\hline California & 118 & 69,607 & 120 & 43,509 & $-1.67 \%$ & $59.98 \%$ \\
\hline Colorado & 15 & 3,349 & 32 & 4,337 & $-53.13 \%$ & $-22.78 \%$ \\
\hline Connecticut & 30 & 12,902 & 23 & 17,638 & $30.43 \%$ & $-26.85 \%$ \\
\hline Delaware & 3 & 1,870 & 6 & (D) & $-50.00 \%$ & $0.00 \%$ \\
\hline Florida & 359 & 57,406 & 449 & 76,696 & $-20.04 \%$ & $-25.15 \%$ \\
\hline Georgia & 79 & 7,502 & 73 & 2,943 & $8.22 \%$ & $154.91 \%$ \\
\hline Hawaii & 59 & 13,761 & 85 & 16,541 & $-30.59 \%$ & $-16.81 \%$ \\
\hline Idaho & 35 & 37,685 & 38 & 35,919 & $-7.89 \%$ & $4.92 \%$ \\
\hline Illinois & 47 & 3,176 & 20 & 2,871 & $135.00 \%$ & $10.62 \%$ \\
\hline Indiana & 18 & (D) & 24 & 2,678 & $-25.00 \%$ & $0.00 \%$ \\
\hline lowa & 21 & 1,469 & 10 & 1,628 & $110.00 \%$ & $-9.77 \%$ \\
\hline Kansas & 12 & 342 & 20 & (D) & $-40.00 \%$ & $0.00 \%$ \\
\hline Kentucky & 65 & 2,341 & 27 & 1,628 & $140.74 \%$ & $43.80 \%$ \\
\hline Louisiana & 873 & 101,314 & 683 & 53,220 & $27.82 \%$ & $90.37 \%$ \\
\hline Maine & 50 & 25,580 & 65 & 66,610 & $-23.08 \%$ & $-61.60 \%$ \\
\hline Maryland & 86 & 7,292 & 52 & 14,822 & $65.38 \%$ & $-50.80 \%$ \\
\hline Massachusetts & 157 & 9,342 & 111 & 5,938 & $41.44 \%$ & $57.33 \%$ \\
\hline Michigan & 34 & 2,398 & 47 & 2,028 & $-27.66 \%$ & $18.24 \%$ \\
\hline Minnesota & 77 & 8,412 & 36 & 3,221 & $113.89 \%$ & $161.16 \%$ \\
\hline Mississippi & 403 & 249,704 & 419 & 290,382 & $-3.82 \%$ & $-14.01 \%$ \\
\hline Missouri & 35 & 7,144 & 49 & 5,374 & $-28.57 \%$ & $32.94 \%$ \\
\hline Montana & 8 & 302 & 10 & 304 & $-20.00 \%$ & $-0.66 \%$ \\
\hline Nebraska & 26 & 1,750 & 15 & 2,154 & $73.33 \%$ & $-18.76 \%$ \\
\hline Nevada & - & - & 2 & (D) & $0.00 \%$ & $0.00 \%$ \\
\hline New Hampshire & 10 & 1,054 & 8 & 844 & $25.00 \%$ & $24.88 \%$ \\
\hline New Jersey & 87 & 3,714 & 28 & 5,787 & $210.71 \%$ & $-35.82 \%$ \\
\hline New Mexico & 3 & (D) & 3 & (D) & $0.00 \%$ & $0.00 \%$ \\
\hline New York & 54 & 8,913 & 54 & 1,833 & $0.00 \%$ & $386.25 \%$ \\
\hline North Carolina & 186 & 24,725 & 147 & 11,510 & $26.53 \%$ & $114.81 \%$ \\
\hline North Dakota & 1 & (D) & 4 & (D) & $-75.00 \%$ & $0.00 \%$ \\
\hline Ohio & 55 & 3,185 & 33 & 1,788 & $66.67 \%$ & $78.13 \%$ \\
\hline Oklahoma & 20 & 1,958 & 18 & 3,639 & $11.11 \%$ & $-46.19 \%$ \\
\hline Oregon & 47 & 12,478 & 34 & 3,572 & $38.24 \%$ & $249.33 \%$ \\
\hline Pennsylvania & 56 & 8,951 & 51 & 7,632 & $9.80 \%$ & $17.28 \%$ \\
\hline Rhode Island & 12 & 840 & 3 & (D) & $300.00 \%$ & $0.00 \%$ \\
\hline South Carolina & 85 & 4,773 & 27 & 4,630 & $214.81 \%$ & $3.09 \%$ \\
\hline South Dakota & 7 & 484 & 9 & 996 & $-22.22 \%$ & $-51.41 \%$ \\
\hline Tennessee & 45 & 1,286 & 39 & 3,901 & $15.38 \%$ & $-67.03 \%$ \\
\hline Texas & 95 & 35,359 & 81 & 20,403 & $17.28 \%$ & $73.30 \%$ \\
\hline Utah & 11 & 559 & 18 & 1,931 & $-38.89 \%$ & $-71.05 \%$ \\
\hline Vermont & 9 & 80 & 8 & 155 & $12.50 \%$ & $-48.39 \%$ \\
\hline Virginia & 147 & 40,939 & 294 & 24,629 & $-50.00 \%$ & $66.22 \%$ \\
\hline Washington & 194 & 93,203 & 91 & 56,646 & $113.19 \%$ & $64.54 \%$ \\
\hline West Virginia & 21 & 1,145 & 27 & 691 & $-22.22 \%$ & $65.70 \%$ \\
\hline Wisconsin & 84 & 7,025 & 95 & 5,226 & $-11.58 \%$ & $34.42 \%$ \\
\hline Wyoming & 7 & 209 & 9 & 317 & $-22.22 \%$ & $-34.07 \%$ \\
\hline Average & & & & & $23.57 \%$ & $23.04 \%$ \\
\hline
\end{tabular}

Table 9: GIS Percent Change in U.S. Aquaculture (1998-2005) Source: Amended 2007 NASS Census of Aquaculture 


\begin{tabular}{|c|c|c|c|c|c|c|}
\hline & Ornamentals & Baitfish & $\begin{array}{l}\text { Commercial } \\
\text { Food fish }\end{array}$ & $\begin{array}{l}\text { Freshwater } \\
\text { Game fish }\end{array}$ & $\begin{array}{l}\text { Marine } \\
\text { Game fish }\end{array}$ & \begin{tabular}{|l} 
Wirth \& \\
Luzar \\
Computed \\
Regulatory \\
Climate \\
Scale \\
Values
\end{tabular} \\
\hline \multicolumn{7}{|l|}{ States } \\
\hline Alabama & 2 & 2 & 0 & 9 & 2 & 3 \\
\hline Alaska & $\mathrm{N} / \mathrm{A}$ & $\mathrm{N} / \mathrm{A}$ & $\mathrm{N} / \mathrm{A}$ & $\mathrm{N} / \mathrm{A}$ & $\mathrm{N} / \mathrm{A}$ & $\mathrm{N} / \mathrm{A}$ \\
\hline Arizona & 8 & 10 & 16 & 16 & 16 & 13 \\
\hline Arkansas & 0 & 0 & 0 & 2 & $\mathrm{~N} / \mathrm{A}$ & 1 \\
\hline California & 8 & 10 & 11 & 11 & 11 & 10 \\
\hline Colorado & 10 & 10 & 12 & 16 & $\mathrm{~N} / \mathrm{A}$ & 12 \\
\hline Connecticut & $\mathrm{N} / \mathrm{A}$ & $\mathrm{N} / \mathrm{A}$ & $\mathrm{N} / \mathrm{A}$ & $\mathrm{N} / \mathrm{A}$ & $\mathrm{N} / \mathrm{A}$ & $\mathrm{N} / \mathrm{A}$ \\
\hline Delaware & 4 & 3 & 6 & 6 & 7 & 5 \\
\hline Florida & 0 & 0 & 0 & 6 & 4 & 2 \\
\hline Georgia & 12 & 10 & 10 & 10 & 10 & 10 \\
\hline Hawaii & 4 & 4 & 14 & 8 & 8 & 8 \\
\hline Idaho & 12 & 12 & 10 & 12 & $\mathrm{~N} / \mathrm{A}$ & 12 \\
\hline Illinois & 3 & 3 & 4 & 5 & N/A & 4 \\
\hline Indiana & N/A & $\mathrm{N} / \mathrm{A}$ & $\mathrm{N} / \mathrm{A}$ & $\mathrm{N} / \mathrm{A}$ & $\mathrm{N} / \mathrm{A}$ & $\mathrm{N} / \mathrm{A}$ \\
\hline lowa & 1 & 9 & 13 & 11 & $\mathrm{~N} / \mathrm{A}$ & 9 \\
\hline Kansas & 3 & 3 & 3 & 3 & $\mathrm{~N} / \mathrm{A}$ & 3 \\
\hline Kentucky & 2 & 2 & 2 & 4 & N/A & 3 \\
\hline Louisiana & 7 & 4 & 6 & 9 & 9 & 7 \\
\hline Maine & $\mathrm{N} / \mathrm{A}$ & $\mathrm{N} / \mathrm{A}$ & 11 & $\mathrm{~N} / \mathrm{A}$ & N/A & 11 \\
\hline Maryland & 10 & 14 & 14 & 14 & 14 & 13 \\
\hline Massachusetts & $\mathrm{N} / \mathrm{A}$ & $\mathrm{N} / \mathrm{A}$ & $\mathrm{N} / \mathrm{A}$ & $\mathrm{N} / \mathrm{A}$ & $\mathrm{N} / \mathrm{A}$ & $\mathrm{N} / \mathrm{A}$ \\
\hline Michigan & 6 & 6 & 6 & 8 & 5 & 6 \\
\hline Minnesota & $\mathrm{N} / \mathrm{A}$ & $\mathrm{N} / \mathrm{A}$ & 11 & $\mathrm{~N} / \mathrm{A}$ & $\mathrm{N} / \mathrm{A}$ & 11 \\
\hline Mississippi & 13 & 7 & 2 & 8 & 11 & 8 \\
\hline Missouri & 0 & 0 & 2 & 0 & $\mathrm{~N} / \mathrm{A}$ & 1 \\
\hline Montana & 14 & 16 & 16 & 16 & $\mathrm{~N} / \mathrm{A}$ & 16 \\
\hline Nebraska & 10 & 10 & 10 & 10 & $\mathrm{~N} / \mathrm{A}$ & 10 \\
\hline Nevada & $\mathrm{N} / \mathrm{A}$ & $\mathrm{N} / \mathrm{A}$ & $\mathrm{N} / \mathrm{A}$ & $\mathrm{N} / \mathrm{A}$ & $\mathrm{N} / \mathrm{A}$ & $\mathrm{N} / \mathrm{A}$ \\
\hline New Hampshire & 8 & 16 & 14 & 14 & 15 & 13 \\
\hline New Jersey & $\mathrm{N} / \mathrm{A}$ & $\mathrm{N} / \mathrm{A}$ & $\mathrm{N} / \mathrm{A}$ & $\mathrm{N} / \mathrm{A}$ & $\mathrm{N} / \mathrm{A}$ & $\mathrm{N} / \mathrm{A}$ \\
\hline New Mexico & $\mathrm{N} / \mathrm{A}$ & $\mathrm{N} / \mathrm{A}$ & $\mathrm{N} / \mathrm{A}$ & $\mathrm{N} / \mathrm{A}$ & $\mathrm{N} / \mathrm{A}$ & $\mathrm{N} / \mathrm{A}$ \\
\hline New York & $\mathrm{N} / \mathrm{A}$ & $\mathrm{N} / \mathrm{A}$ & 12 & 16 & 14 & 14 \\
\hline North Carolina & 4 & 3 & 3 & 3 & 7 & 4 \\
\hline North Dakota & 5 & 7 & 10 & 12 & 8 & 8 \\
\hline Ohio & 7 & 5 & 9 & 9 & $\mathrm{~N} / \mathrm{A}$ & 8 \\
\hline Oklahoma & 10 & 10 & 10 & 8 & 8 & 9 \\
\hline Oregon & 11 & 17 & 15 & 17 & 17 & 15 \\
\hline Pennsylvania & 6 & 6 & 6 & 6 & 9 & 7 \\
\hline Rhode Island & 9 & $\mathrm{~N} / \mathrm{A}$ & $\mathrm{N} / \mathrm{A}$ & $\mathrm{N} / \mathrm{A}$ & 11 & 10 \\
\hline South Carolina & 5 & 5 & 8 & 14 & 8 & 8 \\
\hline South Dakota & 8 & 7 & 7 & 11 & $\mathrm{~N} / \mathrm{A}$ & 8 \\
\hline Tennessee & 10 & 14 & 11 & 10 & 8 & 11 \\
\hline Texas & 5 & 5 & 5 & 5 & 5 & 5 \\
\hline Utah & $\mathrm{N} / \mathrm{A}$ & N/A & $\mathrm{N} / \mathrm{A}$ & $\mathrm{N} / \mathrm{A}$ & N/A & $\mathrm{N} / \mathrm{A}$ \\
\hline Vermont & $\mathrm{N} / \mathrm{A}$ & $\mathrm{N} / \mathrm{A}$ & $\mathrm{N} / \mathrm{A}$ & $\mathrm{N} / \mathrm{A}$ & $\mathrm{N} / \mathrm{A}$ & $\mathrm{N} / \mathrm{A}$ \\
\hline Virginia & 6 & 6 & 10 & 8 & 8 & 8 \\
\hline Washington & $\mathrm{N} / \mathrm{A}$ & $\mathrm{N} / \mathrm{A}$ & $\mathrm{N} / \mathrm{A}$ & $\mathrm{N} / \mathrm{A}$ & $\mathrm{N} / \mathrm{A}$ & $\mathrm{N} / \mathrm{A}$ \\
\hline West Virginia & 12 & $\mathrm{~N} / \mathrm{A}$ & 12 & 12 & 12 & 12 \\
\hline Wisconsin & 11 & 8 & 12 & 12 & $\mathrm{~N} / \mathrm{A}$ & 11 \\
\hline Wyoming & $\mathrm{N} / \mathrm{A}$ & N/A & $\mathrm{N} / \mathrm{A}$ & $\mathrm{N} / \mathrm{A}$ & $\mathrm{N} / \mathrm{A}$ & $\mathrm{N} / \mathrm{A}$ \\
\hline
\end{tabular}

Table 10: Raw Wirth and Luzar 2000 Dataset for Regulatory Stringency Source: Amended Wirth and Luzar 2000 


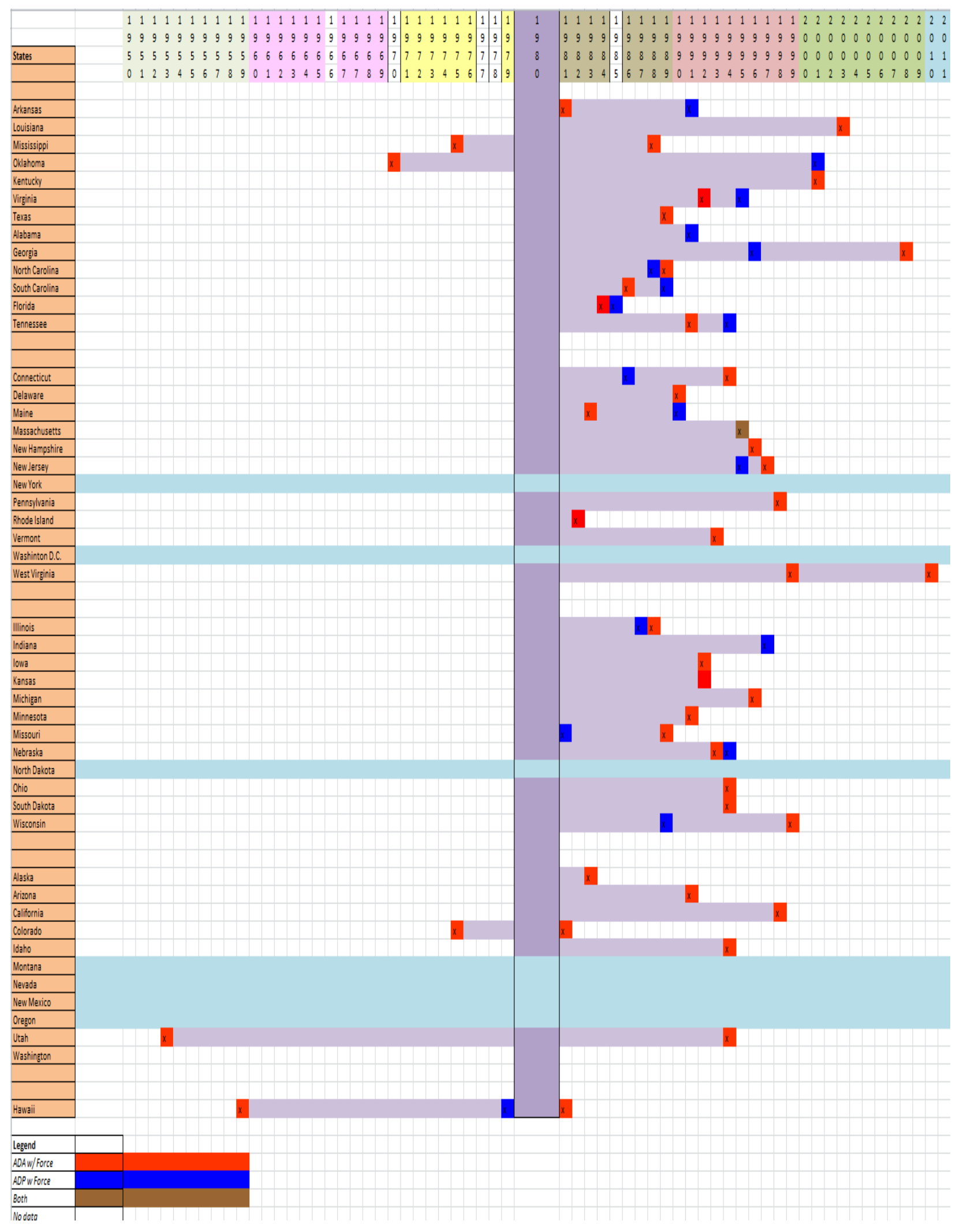

Table 11: Individual U.S. State Aquaculture Regulatory Time Dataset Source: Amended Westlaw Review 


\begin{tabular}{|c|c|c|c|c|c|c|c|}
\hline & $\begin{array}{c}\text { Has the } \\
\text { State } \\
\text { enacted } \\
\text { developme } \\
\text { nt } \\
\text { legislation? }\end{array}$ & \begin{tabular}{|c|} 
\\
Date of \\
Formal \\
Legislative \\
Enactment
\end{tabular} & $\begin{array}{l}\text { Has the } \\
\text { State } \\
\text { enacted a } \\
\text { developm } \\
\text { ent act? }\end{array}$ & \begin{tabular}{|c|} 
If Yes, \\
when was \\
the \\
developm \\
ent act \\
completed \\
$?$
\end{tabular} & \begin{tabular}{|} 
Has the \\
State \\
completed \\
a \\
developm \\
ent plan?
\end{tabular} & $\begin{array}{c}\text { Year } \\
\text { Complete } \\
\mathrm{d} \\
\text { Developm } \\
\text { ent Plan }\end{array}$ & $\begin{array}{c}\text { Length of } \\
\text { Time for } \\
\text { Completio } \\
\mathrm{n}\end{array}$ \\
\hline \multicolumn{8}{|c|}{$\begin{array}{ll} \\
\end{array}$} \\
\hline Alabama & Yes & 1991 & No & $\mathrm{N} / \mathrm{A}$ & Yes & 1991 & 1 Yrs. \\
\hline Alaska & Yes & 1983 & No & $\mathrm{N} / \mathrm{A}$ & $\mathrm{N} / \mathrm{A}$ & N/A & N/A \\
\hline Arizona & Yes & 1989-1991 & Yes & 1991 & $\mathrm{~N} / \mathrm{A}$ & $\mathrm{N} / \mathrm{A}$ & N/A \\
\hline Arkansas & Yes & 1981 & N/A & N/A & Yes & 1991 & 1 Yrs. \\
\hline California & Yes & 1982-1998 & Yes & 1998 & NO & No & No \\
\hline Colorado & Yes & 1975-1981 & Yes & 1981 & N/A & N/A & $\mathrm{N} / \mathrm{A}$ \\
\hline Connecticut & Yes & 1994 & Yes & 1994 & Yes & 1986 & 2 Yrs. \\
\hline Delaware & Yes & 1990 & Yes & 1990 & $\mathrm{~N} / \mathrm{A}$ & $\mathrm{N} / \mathrm{A}$ & N/A \\
\hline Florida & Yes & 1985 & Yes & 1984 & Yes & 1985 & 2Yrs. \\
\hline Georgia & Yes & 1996-2008 & Yes & 2008 & Yes & 1996 & 4 Yrs. \\
\hline Hawaii & Yes & 1959-1981 & Yes & 1981 & Yes & 1979 & 2 Yrs. \\
\hline Idaho & Yes & 1992-1994 & Yes & 1994 & $\mathrm{~N} / \mathrm{A}$ & N/A & $\mathrm{N} / \mathrm{A}$ \\
\hline Illinois & Yes & 1988 & Yes & 1988 & Yes & 1987 & 2 Yrs. \\
\hline Indiana & Yes & 1995-1997 & Yes & N/A & Yes & 1997 & 2 Yrs. \\
\hline Iowa & Yes & 1992 & $\mathrm{~N} / \mathrm{A}$ & $\mathrm{N} / \mathrm{A}$ & N/A & N/A & N/A \\
\hline Kansas & Yes & 1992 & Yes & 1992 & N/A & $\mathrm{N} / \mathrm{A}$ & N/A \\
\hline Kentucky & Yes & 1998-2002 & Yes & 2001 & N/A & $\mathrm{N} / \mathrm{A}$ & N/A \\
\hline Louisiana & Yes & 2003 & Yes & 2003 & Yes & 2000 & $5-10$ yrs. \\
\hline Maine & Yes & 1983 & Yes & N/A & Yes & 1990 & 1 Yrs. \\
\hline Maryland & Yes & 1987 & Yes & 1988 & $\mathrm{~N} / \mathrm{A}$ & N/A & N/A \\
\hline Massachusetts & Yes & 1995 & Yes & 1995 & Yes & 1995 & 1 \\
\hline Michigan & Yes & 1996 & Yes & 1996 & N/A & N/A & N/A \\
\hline Minnesota & Yes & 1991 & Yes & 1991 & N/A & $\mathrm{N} / \mathrm{A}$ & N/A \\
\hline Mississippi & Yes & 1975 & Yes & 1988 & No & No & No \\
\hline Missouri & Yes & 1989 & Yes & 1989 & Yes & 1991 & N/A \\
\hline Montana & $\mathrm{NO}$ & N/A & N/A & N/A & $\mathrm{N} / \mathrm{A}$ & N/A & N/A \\
\hline Nebraska & Yes & 1987 & Yes & 1993 & Yes & 1994 & $\mathrm{~N} / \mathrm{A}$ \\
\hline Nevada & $\mathrm{N} / \mathrm{A}$ & N/A & $\mathrm{N} / \mathrm{A}$ & N/A & $\mathrm{N} / \mathrm{A}$ & N/A & $\mathrm{N} / \mathrm{A}$ \\
\hline New Hamsphire & Yes & 1978 & Yes & 1992 & $\mathrm{~N} / \mathrm{A}$ & $\mathrm{N} / \mathrm{A}$ & $\mathrm{N} / \mathrm{A}$ \\
\hline New Jersey & Yes & 1997 & Yes & 1997 & Yes & 1995 & 3 \\
\hline New Mexico & N/A & N/A & N/A & N/A & $\mathrm{N} / \mathrm{A}$ & N/A & $\mathrm{N} / \mathrm{A}$ \\
\hline New York & N/A & N/A & N/A & N/A & $\mathrm{N} / \mathrm{A}$ & N/A & N/A \\
\hline North Carolina & Yes & 1989 & Yes & 1989 & Yes & 1988 & 1 \\
\hline North Dakota & N/A & N/A & N/A & N/A & N/A & $\mathrm{N} / \mathrm{A}$ & N/A \\
\hline Ohio & Yes & N/A & No & No & Yes & 2010 & 2 Yrs. \\
\hline Oklahoma & Yes & $1970-2002$ & $\mathrm{~N} / \mathrm{A}$ & $\mathrm{N} / \mathrm{A}$ & Yes & 2001 & $\mathrm{~N} / \mathrm{A}$ \\
\hline Oregon & $\mathrm{N} / \mathrm{A}$ & N/A & $\mathrm{N} / \mathrm{A}$ & $\mathrm{N} / \mathrm{A}$ & $\mathrm{N} / \mathrm{A}$ & $\mathrm{N} / \mathrm{A}$ & $\mathrm{N} / \mathrm{A}$ \\
\hline Pennsylvania & Yes & 1998 & Yes & 1998 & N/A & N/A & $\mathrm{N} / \mathrm{A}$ \\
\hline Rhode Island & Yes & $1982-2001$ & N/A & N/A & N/A & N/A & N/A \\
\hline South Carolina & Yes & 1986-2003 & Yes & 1988 & Yes & 1989 & 4 \\
\hline South Dakota & Yes & 1994 & N/A & N/A & N/A & N/A & N/A \\
\hline Tennessee & Yes & 1991 & Yes & 1991 & Yes & 1994 & 1 \\
\hline Texas & Yes & 1989 & Yes & 1989 & N/A & N/A & $\mathrm{N} / \mathrm{A}$ \\
\hline Utah & Yes & 1953 & Yes & 1994 & Yes & 1994 & N/A \\
\hline Vermont & Yes & 1993 & No & No & No & No & No \\
\hline Virginia & Yes & 1992 & Yes & 1992 & Yes & 1995 & 2 \\
\hline Washington & Yes & N/A & Yes & N/A & $\mathrm{N} / \mathrm{A}$ & N/A & N/A \\
\hline West Virginia & Yes & 1999-2010 & Yes & 2010 & NO & NO & NO \\
\hline Wisconsin & Yes & 1999 & N/A & $\mathrm{N} / \mathrm{A}$ & Yes & 1988 & 2 \\
\hline Wyoming & $\mathrm{N} / \mathrm{A}$ & N/A & $\mathrm{N} / \mathrm{A}$ & N/A & N/A & N/A & N/A \\
\hline
\end{tabular}

Table 12: State Summary Review Dataset (A.)

Source: Amended Westlaw Review 


\begin{tabular}{|c|c|c|c|c|}
\hline & $\begin{array}{c}\text { Does the } \\
\text { state } \\
\text { have a } \\
\text { lead } \\
\text { agency? }\end{array}$ & Which agency acts as "lead agency"? & \begin{tabular}{|c|} 
Does the \\
state have \\
an \\
aquacultu \\
fe \\
coordinat \\
of Expert \\
Contact?
\end{tabular} & Does the state have an advisory board council committee? \\
\hline \multicolumn{5}{|l|}{ States } \\
\hline Alabama & Yes & AL Department of Agriculture \& Industries-(AL DOA) & Yes & Aquaculture Task Force Appointed \\
\hline Alaska & Yes & AK Department of Agriculture (AK DOA) \& AK Department of Fish \& Game (AK DFG) & Yes & N/A \\
\hline Arizona & Yes & AZ Department of Agriculture (AZ DOA) & Yes & N/A \\
\hline Arkansas & Yes & AR Department of Agriculture (AR DOA) \& AR Fish \& Game Commisssion (AR GFC) & Yes & Agricultural Ancillary Development Committee \\
\hline Califormia & Yes & CA Department of Fish \& Game (CA DFG) & Yes & Aquaculture Industry Advisory Committee \\
\hline Colorado & Yes & CO Department of Agriculture (CO DOA) & Yes & Aquaculture Board \\
\hline Connecticut & Yes & CT Department of Agriculture (CT DOA) & Yes & Interagency Aquaculture Coordinating Committee \\
\hline Delaware & Yes & DE Department of Agriculture (DE DOA) & Yes & Aquaculture Council \\
\hline Florida & Yes & FL Deparment of Agriculture (FL DOA) & Yes & Aquaculture Review Council \& Interagency Coordinating Council \\
\hline Georgia & Yes & GA Department of Natural Resources (GA DNR) & Yes & Aquaculture Focused Development Commission \\
\hline Hawaii & Yes & HI Department of Agriculture (HI DOA) & Yes & Aquaculture Advisory Council \\
\hline Idaho & Yes & ID Department of Agriculture (ID DOA) & Yes & Agricultural Development Commission \\
\hline Illinois & Yes & IL Department of Agriculture (L DOA) & Yes & Aquaculture Advisory Committee \\
\hline Indiana & Yes & NN Department of Agriculture (NDOA) & Yes & Invasive Species Control Council \\
\hline Iowa & Yes & Department of Natural Resources \& Department of Agriculture & Yes & $\mathrm{N} / \mathrm{A}$ \\
\hline Kansas & Yes & KS Department of Agriculture (KS DOA) & Yes & Aquaculture Advisory Council \\
\hline Kentucky & Yes & KY Department of Agriculture (KY DOA) & Yes & KY Aquaculture Task Force \\
\hline Louisiana & Yes & LA Department of Agriculture (LADOA) & Yes & Aquaculture Task Force, Seafood Safety Task Force, Legislative Development Commission \\
\hline Maine & Yes & ME Department of Marine Resources (ME DMR) & Yes & Aquaculture Advisory Council, Shellfish Advisory Council, etc. \\
\hline Maryland & Yes & MD Department of Agriculture (MD DOA) \& MD Department of Natural Resources (MD DNR) & Yes & Aquaculture Review Board and Coordinating Council \\
\hline Massachusetts & Yes & MA Department of Agriculture (MA DOA) \& MA Department of Marine Fisheries (MA DMF) & Yes & State Aquaculture Advisory Committee \\
\hline Michigan & Yes & MI Department of Agriculture (MIDOA) & Yes & $\mathrm{N} / \mathrm{A}$ \\
\hline Minnesota & Yes & MN Department of Agriculture (MN DOA) & Yes & MN Aquaculture Association-Advisory Committee \\
\hline Mississippi & Yes & MS Department of Agniculture (MS DOA) & Yes & Aquaculture Task Force \\
\hline Missouri & Yes & MO Department of Agriculture (MO DOA) & Yes & Industry Advisory Council \\
\hline Montana & $\mathrm{N} / \mathrm{A}$ & $\mathrm{N} / \mathrm{A}$ & N/A & $\mathrm{N} / \mathrm{A}$ \\
\hline Nebraska & Yes & NB Department of Agriculture (NB DOA) & Yes & Aquaculture Board \\
\hline Nevada & N/A & $\mathrm{N} / \mathrm{A}$ & $\mathrm{N} / \mathrm{A}$ & N/A \\
\hline New Hamsphire & Yes & NH Fish and Game Commission (NH FGC) & Yes & Interagency Cooperative Shellfish Program \\
\hline New Jersey & Yes & NJ Department of Agriculture (NJ DOA) & Yes & Aquaculture Development Task Force \\
\hline New Mexico & $\mathrm{N} / \mathrm{A}$ & $\mathrm{N} / \mathrm{A}$ & $\mathrm{N} / \mathrm{A}$ & $\mathrm{N} / \mathrm{A}$ \\
\hline New York & Yes & NY Department of Agriculture & Yes & $\mathrm{N} / \mathrm{A}$ \\
\hline North Carolina & Yes & NC Department of Agriculture (NC DOA) & Yes & Aquaculture Advisory Board, Joint Legislative Commission on Seafood and Aquaculture \\
\hline North Dakota & $\mathrm{N} / \mathrm{A}$ & $\mathrm{N} / \mathrm{A}$ & N/A & $\mathrm{N} / \mathrm{A}$ \\
\hline Ohio & Yes & OH Department of Agriculture (OH DOA) & Yes & Aquaculture Development Task Force \\
\hline Oklahoma & Yes & OK Department of Agriculture (OK DOA) & Yes & Aquaculture Advisory Council \\
\hline Oregon & $\mathrm{N} / \mathrm{A}$ & $\mathrm{N} / \mathrm{A}$ & $\mathrm{N} / \mathrm{A}$ & $\mathrm{N} / \mathrm{A}$ \\
\hline Pennsylvania & Yes & PA Department of Agriculture (PA DOA) & Yes & Advisory Committee \\
\hline Rhode Island & Yes & RI Department of Fish and Widdlife (RI DFW) & Yes & $\mathrm{N} / \mathrm{A}$ \\
\hline South Carolina & Yes & SC Department of Agriculture (SCDOA) \& SC Department of Natural Resources (SC DNR) & Yes & SC Aquaculture Association \\
\hline South Dakota & Yes & SD Department of Natural Resources (SD DNR) & Yes & $\mathrm{N} / \mathrm{A}$ \\
\hline Tennessee & Yes & TN Department of Agriculture (TN DOA) & Yes & Aquaculture Advisory Board \\
\hline Texas & Yes & TX Department of Agriculture (TXDOA) & Yes & Aquatic Animal Health Commission, Aquaculture Advisory Board \\
\hline Utah & Yes & UT Department of Agriculture (UT DOA) & Yes & Aquaculture Advisory Board, Fish Health Policy Board \\
\hline Vermont & Yes & VT Department of Agriculture (VT DOA) \& VT Department of Fish and Wildlife (VT DFW) & Yes & No \\
\hline Virginia & Yes & VA Department of Agniculture (VA DOA) & Yes & VA Aquaculture Association, VA Marine Resource Commission \\
\hline Washington & Yes & WA Department of Agriculture (WA DOA) & Yes & $\mathrm{N} / \mathrm{A}$ \\
\hline West Virginia & Yes & WV Department of Agriculture (WV DOA) & Yes & Aquaculture Advisory Board \\
\hline Wisconsin & Yes & WS Department of Agriculture (WIDOA) & Yes & Advisory Board \\
\hline Wyoming & N/A & $\mathrm{N} / \mathrm{A}$ & N/A & N/A \\
\hline
\end{tabular}

Table 13: State Summary Review Dataset (B.)

Source: Amended Westlaw Review 


\begin{tabular}{|c|c|c|c|c|c|}
\hline & \begin{tabular}{|l|} 
Has the State Enacted \\
More Stringent \\
Discharge Regulation?
\end{tabular} & Has the state enacted more stringent discharge regulation? & \begin{tabular}{|c|} 
Has State \\
Enacted \\
more \\
stringent \\
regulation \\
pertaining \\
to \\
AAHM?
\end{tabular} & Has the state enacted more stringent aquatic animal health standards? & $\begin{array}{l}\text { Does the } \\
\text { state have } \\
\text { higher } \\
\text { edicucation } \\
\text { involved? }\end{array}$ \\
\hline \multicolumn{6}{|c|}{ gong } \\
\hline Alaboma & No & Follows State Driven B.MPS \& ELG's from EPA & Yes & Regs for Importation of Fingerfings from MS, Catfish Testing Compliance w/ compliance USDA APHIS (S & Yes \\
\hline Alaska & $\mathrm{N}_{0}$ & Effluent Limitation Guideline Requirement from EPA & NA & N/A & Yes \\
\hline Arizona & Yes & State Driven NPDES Permit Program & Yes & Importation Certification Required & Yes \\
\hline Arkansas & $\mathrm{N}_{0}$ & Effluent Limitation Guidedine Requirement from EPA & Yes & Voluntary Exportation Certification & Yes \\
\hline California & Yes & State Discharge Program & Yes & Facility Certification and Disease Testing & Yes \\
\hline Colorado & Yes & Plannwide Discharge Permit & Yes & Aquatic Disease Importation Certification & Yes \\
\hline Connecticut & Yes & Discharge Permit Requirement by the State & Yes & Facility Certification Requirement for Invasive Species & Yes \\
\hline Delaware & Yes & Discharge Permit for NPDES & NA & NA & Yes \\
\hline Florida & Yes & NPDES Permit Program & NA & Best Nanangement Practice Requirement for Health Certification by APHIS & Yes \\
\hline Georgia & NA & BMPs & NA & B.MPs & Yes \\
\hline Hawaii & Yes & Water Usage Permits & Yes & Importation Requirements & Yes \\
\hline Idaho & Yes & NPDES Permit Program & Yes & Management Rules for Insprection and Certification & Yes \\
\hline Illinois & N/A & $\mathrm{NA}$ & Yes & State Importation Certification Requirements & Yes \\
\hline Indiana & Yes & NPDES Permit Program & Yes & Invasive Species Inventory \& Importation Certification Requirements & Yes \\
\hline Iowa & & N/A & 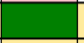 & NA & Yes \\
\hline Kansas & $\mathrm{N}_{0}$ & State Follows Federal NPDES & $\mathrm{NAA}$ & $\mathrm{N} / \mathrm{A}$ & Yes \\
\hline Kentucky & No & Follows Federal NPDES Mandate & Yes & State Importation Certification Requirements & Yes \\
\hline Louisiana & $\mathrm{N}_{0}$ & Follows Federal Dischargeg Guidedines & Yes & Requirement for Transportation and Importation of Live Species & Yes \\
\hline Maine & Yes & State Waste Discharge Permit for Harcheries & Yes & Shellishs Health Monitoring Program & Yes \\
\hline Maryland & Yes & State Monitored Discharge Program & Yes & Transpoortation and Importation Certification Rquirement & Yes \\
\hline Massachusetts & Yes & State Discharge Program & Yes & Shellfish Monitoring Requirements & Yes \\
\hline Michigan & Yes & State Discharge Program & Yes & Facility Inspection \& Importation Cerification Requirements & Yes \\
\hline Nimesosta & Yes & State NPDES permit requirement & $N_{0}$ & APHIS USDA requirements & Yes \\
\hline Missisisppi & Yes & State Monitiored Discharge Program & Yes & Importation and Exportation Certification Requirementsts For Catrish & Yes \\
\hline Missouri & Yes & Water Dischargese Permit requirement & No & VHS Nandates by APHIS (USDA) & Yes \\
\hline Montana & & NA & & NA & Yes \\
\hline Nebraska & No & Follows Federal Discharge Guidditines & Yes & Facility Inspection Requirements & Yes \\
\hline Nerada & & NA & & NA & Yes \\
\hline New Hamsphire & N/A & NA & $\mathrm{N} / \mathrm{A}$ & N/A & Yes \\
\hline New Jersey & Yes & State Waste Discharge Permit & Yes & Transpoortation and Importation Certification Rquirement & Yes \\
\hline New Mexico & & NA & & NA & Yes \\
\hline New York & & NA & & $\mathrm{NA}$ & Yes \\
\hline North Carolina & Yes & NPDES Cold Water Production & Yes & Importation and Exportation Certification requirements & Yes \\
\hline North Dakota & & $\mathrm{N} / \mathrm{A}$ & & NA & Yes \\
\hline Ohio & No & In Development Phase & Yes & State Monitored Plantridide Certification Requirment & Yes \\
\hline Oklahoma & Yes & Agriculuture Pollutunt Discharge Program (AGPDES) & Yes & Importation and Exportation Certification requirements & Yes \\
\hline Oregon & & N/A & & NA & Yes \\
\hline Pennsylvania & 1.0 & ollows Federal Mandates Until State DrivenProgram is Completete & Yes & State Monited Plantwide Certification Requirements & Yes \\
\hline & & NA & & Required Pathogen Certification & Yes \\
\hline South Carolina & Yes & Coastal Zone Manngement Plan applies NPDES & Yes & Mandatory Facility Inspection Requirements & Yes \\
\hline South Dakota & Yes & State Monitored Discharge Program & Yes & Importation and Exportation Certifiction requirements & Yes \\
\hline Temnesset & Yes & State Driven NPDES Permit Program & Yes & General Heath management certicication & Yes \\
\hline Texas & Yes & Waste Water Discharge Program & Yes & State Monitored Certification Requirements & Yes \\
\hline Utah & $\mathrm{NA}$ & $\mathrm{NA}$ & Yes & State Mandated Facility Inspection \& Health Nanangement Certification Requirement & Yes \\
\hline Vermont & No & Follows Federal NPDES Mandate & Yes & Mandatory Pathogen Testing Requirements For Live Specimens & Yes \\
\hline Virgimia & Yes & State Promoted NPDES Program & Yes & State Monitored General Health Certicication Program & Yes \\
\hline Washington & Yes & State NPDES permit requirement (Finfish Cullure) & No & State Monitored Certification follows APHIS & Yes \\
\hline West Virginia & No & In Development Phase & $\mathrm{N}_{0}$ & In Develoomment Phase & Yes \\
\hline Wisconsin & No & In Development Phase & $\mathrm{N}_{0}$ & In Develooment Phase & Yes \\
\hline & & N/A & & NA & Yes \\
\hline
\end{tabular}

Table 14: State Summary Review Dataset (C.) Source: Amended Westlaw Review 


\section{STATE SUMMARY “QUICK SHEETS”}

\section{PURPOSE}

This section will provided quick access information for each state evaluated. The state summaries are purported to be a general representative illustration of the states reviewed. This information will aid the research of industry experts" or potential aquaculturists seeking additional knowledge.

The U.S. states that comprise the survey area now are published as the summaries for the appendices. The following areas were evaluated as indicators of industry development:

1.) Legislative Acknowledgment through:

a. Statutes,

b. Administrative Rules and other pertinent regulation,

2.) Development Criteria,

3.) Wirth \& Luzar Ranking,

4.) Species Cultured (i.e. most predominant cultured),

5.) State Production Values based on NASS 2007 Census of Aquaculture,

6.) State Regulatory Agencies Influencing Aquaculture,

7.) Commentary,

8.) Sources of Information,

a. Expert Contacts

b. Further References Utilized

This summary section collates over two-years of intensive research into one reference. Seven states: Montana, Nevada, New Mexico, New York, North Dakota, Oregon, and Wyoming were found to possess minimal or no statutory references. Based on this finding, the states with no statutory records were removed from this appendix. 


\section{States}

Alabama- $(A L)$

- Applicable Statutes:

Code 1975 §2-3A-2,

$\S 2-11-33$, $\S 9-12-54.1$,

- Other Rules \& Regulation:

ALA. ADMIN. CODE Chapter 80- Agriculture

$\S 80-3-8$ et seq. (Livestock Markets \& Disease Control), \$80-8-6 et seq. (Catfish Promotional), $\S 80-8-10$ et seq. (Shrimp Promotional),

- Evaluation Criteria:

1.) Has the State enacted development legislation?- (Yes),

2.) Date of formal legislative enactment?- (1991),

3.) Has the State enacted a development act?- (No),

4.) If Yes, when was the development act completed?- (N/A),

5.) Has the State completed a development plan?- (Yes),

6.) If Yes, when was the development plan completed?- (1991),

7.) What was the timeframe for completion?- (1yr),

8.) Does the State have a tead agency?"- (Yes),

9.) Which agency is tead agency?"- [Alabama Department of Agriculture \& Industries] (AL DOA),

10.) Does the State have an aquaculture coordinator/Expert contact?- (Yes),

11.) Does the State have an advisory board/council/committee/task force?- (Yes),

12.) If Yes, does the panel still exist?- (NO),

13.) Has the State enacted more stringent discharge regulation?- (NO),

14.) What has the state enacted?- [Follows Best Management Practices (BMP's) and Effluent Limitation Guidelines (ELG's) created by EPA],

15.) Has the State enacted more stringent aquatic animal health standards (AAHM)(Yes),

16.) What is the AAHM regulation?- [Certification requirement for importation of fingerlings from Mississippi], \& [Catfish are tested in compliance with USDA APHIS. State certified],

17.) Does the State have higher education participation?- (Yes),

- Wirth \& Luzar (2000) Regulatory Stringency Value: “3”

- Species Cultured:

catfish, yellow perch, crayfish, tilapia, shrimp, largemouth bass, bluegill, etc. 
- Regulatory Agencies:

a.) Alabama Department of Agriculture \& Industries (AL DOA)- Lead Agency,

b.) Alabama Department of Environmental Management (ADEM),

c.) Alabama Department of Conservation \& Natural Resources (AL DNR).

- Production Value (2007):

Catfish- $\$ 95,675,000$,

Trout- N/A

Foodfish- $\$ 99,458$,

Baitfish- N/A,

Crustaceans- $\$ 592,000$,

Ornamental- \$299,000,

Mollusks- N/A

Sport fish- $\$ 2,677,000$,

- Commentary:

-Three central processors exist in the state to handle the large amount of production taking place. Small amount of regulation exists but large production occurs.

- Sources:

James Carlisle- ALFA Farmers Organization

1-334-288-3900

jcarlisle@,alfafarmers.org

Mitt Walker- ALFA Farmers Organization (Catfish)

1-800-392-5705 ext. 4757

James McAfee- Alabama Department of Environmental Management (ADEM)

$1-334-394-4301$

John Gamble- Alabama Department of Agriculture \& Industries (AL DOA), Marketing \& Economics Department

1-334-240-7245

john.gamble@agi.alabama.gov

-Alabama Administrative Code: Search Aquaculture Regulation”-

http://alabamaadministrativecode.state.al.us/alabama.html 
Alaska- (AK)

- Applicable Statutes:

Const. Art. 8, §15, (State Water Access Legislation)

AK ST $§ 16.05 .055$ (1-15), (AK DFG, lead agency designation \& duties)

\$38.04.015, Agricultural Designation Classification

$\$ 38.04 .035$, State Promotion Declaration

$\S 41.21 .302$, Marine aquaculture development in regulated sanctuaries

- Other Rules \& Regulation:

$-\mathrm{N} / \mathrm{A}$

- Evaluation Criteria:

1.) Has the State enacted development legislation?- (Yes,

2.) Date of formal legislative enactment?- (1983),

3.) Has the State enacted a development act?- (No), but relies on [State Aquatic Farm Act- (1998)],

4.) If Yes, when was the development act completed?- (N/A),

5.) Has the State completed a development plan?- (N/A),

6.) If Yes, when was the development plan completed?- (N/A),

7.) What was the timeframe for completion?- (N/A),

8.) Does the State have a tead agency?"- (Yes),

9.) Which agency is tead agency?"- [-Joint Appointment"-Alaska Department of Agriculture (AK DOA) \& Alaska Department of Fish \& Game (AK DFG)],

10.) Does the State have an aquaculture coordinator/Expert contact?- (Yes),

11.) Does the State have an advisory board/council/committee/task force?- (N/A),

12.) If Yes, does the panel still exist?- (N/A),

13.) Has the State enacted more stringent discharge regulation?- (NO),

14.) What has the state enacted?- [Follows Effluent Limitation Guidelines (ELG's) created by EPA],

15.) Has the State enacted more stringent aquatic animal health standards (AAHM)?(N/A),

16.) What is the AAHM regulation?- (N/A),

17.) Does the State have higher education participation?-(Yes),

- Wirth \& Luzar (2000) Regulatory Stringency Value: —XA"

- Species Cultured:

Salmon, smolt, shellfish, trout, etc.

- Regulatory Agencies for Aquaculture:

a.) Alaska Department of Fish \& Game (AK DFG), Lead Agency

b.) Alaska Department of Natural Resources (AK DNR), 
- Production Values (2007):

Catfish- N/A,

Trout- N/A,

Foodfish- $\$ 27,785,000$,

Baitfish- N/A,

Crustacean- N/A,

Ornamentals- N/A,

Mollusks- $\$ 745,000$,

Sportfish- N/A

- Commentary:

Alaska lacks a central processor and overall production is small. Disputes over product classification (i.e. wild v. domestic) continue to plague the industry. Water leasing may present a hindrance to development.

- Sources:

Cynthia Pring-Ham- Alaska Department of Fish \& Game (commercial fisheries division) $1-907-465-6150$

Cynthia.pring-ham@alaska.gov

John Thiede- Alaska Department of Natural Resources

1-907-269-8543, 1-907-269-8600.

John.thiede@alaska.gov 
Arizona- (AZ)

- Applicable Statutes:

ARS §3-102, (AZ DOA, legislation authorization for development)-(1989)

\$3-1201, (Agricultural tivestock" classification)

$\$ 3-1202$

ARS T3, Ch.16. Aquaculture Development Act. (1991)

§3-2901, (Duties of AZ DOA)

\$3-2902, (Aquaculture Supervisor)

\$3-2093, (Research \& Dissemination Provisions)

\$3-2904, (Quarantine \& Disease Provisions)

§3-2905, (Inspection \& Certification)

\$3-2907, (Facility Licensure Compliance)

§3-2908, (Special Educational Licensure)

§3-2909, (Water Supply Restriction)

ARS §17-373 Storage/ Transportation Requirements,

$\S 49-248$. (BMP requirements)

- Other Rules \& Regulation:

ARIZ. ADMIN.CODE Title 3 Agriculture. Article 10: Aquaculture

R3-2-1002 (Fees, Licensure)

R3-2-1003 (General Licensure)

R3-2-1004 (Aquaculture Facility Special Licensure)

R3-2-1005 (Fee Fishing Facility)

R3-2-1006 (Processor Licensure)

R3-2-1007 (Transportation)

R3-2-1009 (Disease Certification)

R3-2-1010 (Importation Requirements)

Wildlife

ARIZ ADMIN.CODE Title 12 Natural Resources, Article 3: Taking \& Handling of
R12-4-310 (Permits)
R12-4-311 (Exemptions)
R12-4-312 (Special Use Permits)
R12-4-313 (Wildlife Takings)
R12-4-315 (Possession)
R12-4-316 (Transportation)
R12-4-317-318 (Seasons)

ARIZ ADMIN.CODE Title 18 Environmental Quality, Article 9: Pollutant Discharge Elimination System

Part A. General Requirements

R18-9-A902. AZPDES Permit Transition, Applicability, and Exclusions

R18-9-A903. Prohibitions

R18-9-A904. Effect of a Permit

R18-9-A905. AZPDES Program Standards

R18-9-A906. General Pretreatment Regulations

R18-9-A908. Public Participation, EPA Review, EPA Hearing 
Part B. Individual Permits

R18-9-B901. (Individual Permit Application)

R18-9-B902.( Requested Coverage Under a General Permit)

R18-9-B903. (Individual Permit Issuance or Denial)

R18-9-B904. (Individual Permit Duration, Reissuance, and Continuation)

R18-9-B905. (Individual Permit Transfer)

R18-9-B906. (Modification, Revocation, Reissuance, \& Termination)

R18-9-B907. (Individual Permit Variances)

Part C. General Permits

R18-9-C901. (General Permit Issuance)

R18-9-C902. (Required and Requested Coverage Under an Individual Permit)

R18-9-C903. (General Permit Duration, Reissuance, and Continuation)

R18-9-C904. (Change of Ownership or Operator Under a General Permit)

R18-9-C905. (General Permit Modification and Revocation and Reissuance)

ARIZ ADMIN.CODE Title 18 Environmental Quality, Article 10: Disposal, Use, \& Transportation of Biosolids

R18-9-1003. (General Requirements)

R18-9-1004. (Applicator Registration, Bulk Biosolids)

R18-9-1005. (Pollutant Concentrations)

R18-9-1006. (Class A and Class B Pathogen Reduction Requirements)

R18-9-1007. (Management Practices and General Requirements)

R18-9-1008. (Management Practices)

R18-9-1009. (Site Restrictions)

R18-9-1010. (Vector Attraction Reduction)

R18-9-1011. (Transportation)

R18-9-1012. (Self-monitoring)

R18-9-1013. (Recordkeeping)

R18-9-1014. (Reporting)

R18-9-1015. (Inspection)

- Evaluation Criteria:

1.) Has the State enacted development legislation?- (Yes),

2.) Date of formal legislative enactment?- (1989-1991),

3.) Has the State enacted a development act?- (Yes),

4.) If Yes, when was the development act completed?- (1991),

5.) Has the State completed a development plan?- (N/A),

6.) If Yes, when was the development plan completed?- (N/A),

7.) What was the timeframe for completion?- (N/A),

8.) Does the State have a tead agency?"- (Yes),

9.) Which agency is — lad agency?"- [Arizona Department of Agriculture (AZ DOA)],

10.) Does the State have an aquaculture coordinator/Expert contact?- (Yes),

11.) Does the State have an advisory board/council/committee/task force?- (N/A),

12.) If Yes, does the panel still exist?- (N/A),

13.) Has the State enacted more stringent discharge regulation?- (Yes),

14.) What has the state enacted?- [State Driven NPDES Program], 
15.) Has the State enacted more stringent aquatic animal health standards (AAHM)?(Yes),

16.) What is the AAHM regulation?- [Importation Certification Requirements],

17.) Does the State have higher education participation?- (Yes),

- Wirth \& Luzar (2000) Regulatory Stringency Value: “13”

- Species Cultured:

Catfish, Trout, Crustaceans, Ornamentals, Sport fish, Baitfish, etc.

- Production Values (2007):

Catfish- N/A,

Trout- $\$ 1,349,000$,

Foodfish- N/A,

Baitfish- N/A,

Crustaceans- N/A,

Mollusks- N/A,

Ornamentals- N/A,

Sport fish- $\$ 5,000$

- Regulatory Agencies:

a.) Arizona Department of Agriculture (AZ DOA), Łead Agency,"

b.) Arizona Department of Environmental Quality (AZ DEQ),

c.) Arizona Department of Fish \& Game (AZ DFG),

- Commentary:

During the research phase, Arizona was found to have a friendly" website, full of information on state production. While the contacts were difficult to reach, the state outreach program from the University of Arizona presents loads of useful information.

- Sources:

Dr. John Hall, Arizona Department of Agriculture

$1-602-542-4293$

jhunt@azda.gov

Dr. Kevin Fitzsimmons, Environmental Research Lab (University of Arizona) 1-520-626-3324

kevfitz@ag.arizona.edu

Arizona Administrative Code: Search -Aquaculture Regulation"http://www.azsos.gov/public services/table_of contents.htm 
Arkansas- (AR)

- Applicable Statutes:

A.C.A. §2-1-206, (Ancillary Development Committee) (2003)

\$2-4-102, (Aquaculture is Agriculture) Classification

\$14-144-204, (Capital Investment Access)

$\S 15-5-103$, (Financial Access Provisions)

\$20-61-302, (Catfish Industry Legislation)

\$25-38-203, (2007 Research parks Authorities Act Endorsement)

$\S 25-38-204$, (Transfer Authority Provisions to ARDOA)

§25-38-207, (Arkansas Agriculture Board)

- Other Rules \& Regulation:

SECTION 42.00 - FISH FARMER REGULATIONS

42.01 Fish Farmer (Aquaculturist) Permit Requirements.

42.02 Fish Farmer (Aquaculturist) Sales Records Requirements.

42.03 Fish Farmer (Aquaculturist) Bill of Lading Requirements.

42.04 Fish Farmer (Aquaculturist)Tackle Requirements.

42.05 Transportation or Sale of White Crappie Prohibited.

42.06 Rearing or Propagating Aquatic Wildlife in Confinement

Restricted.

42.07 Fishing in Caged Fish Confinements Prohibited.

42.08 Operating Lakes as a Fish Farm Prohibited.

42.09 Possession, Rearing, Propagation or Sale By Fish Farmers

(Aquaculturist) of Restricted and Unlisted Aquaculture

Species Prohibited.

42.10 Paddlefish and Sturgeon Roe Regulations.

42.11 Viral Hemorrhagic Septicemia Virus (VHSV) Fish

Importation Regulation.

- Evaluation Criteria:

1.) Has the State enacted development legislation?- (Yes),

2.) Date of formal legislative enactment?- (1981),

3.) Has the State enacted a development act?- (N/A),

4.) If Yes, when was the development act completed?- (N/A),

5.) Has the State completed a development plan?- (Yes),

6.) If Yes, when was the development act completed?- (N/A),

7.) What was the timeframe for completion?- (1 Yr),

8.) Does the State have a tead agency?"- (Yes),

9.) Which agency is tead agency?"- [-Joint"-AR DOA \& AR Fish \& Game Commission],

10.) Does the State have an aquaculture coordinator/Expert contact?- (Yes),

11.) Does the State have an advisory board/council/committee/task force?- (Yes)[Aquaculture Ancillary Development Committee],

12.) If Yes, does the panel still exist?- (N/A)

13.) Has the State enacted more stringent discharge regulation?- (No), 
14.) What has the state enacted?- [Effluent Limitation Guidelines (ELG's) by EPA],

15.) Has the State enacted more stringent aquatic animal health standards (AAHM)?(Yes),

16.) What is the AAHM regulation?- [Voluntary Exportation Certification Requirement],

17.) Does the State have higher education participation?- (Yes),

- Wirth \& Luzar (2000) Regulatory Stringency Value: “1”

- Species Cultured:

Catfish, Baitfish, Trout, Ornamentals, Shrimp, Largemouth Bass, Carp, Bluegill, Turtles, Tilapia, Crawfish, Paddlefish, etc.

- Production Values (2007):

Catfish- $\$ 78,133,000$

Trout- $\$ 3,367,000$

Foodfish- $\$ 2,844,000$

Baitfish- $\$ 21,545,000$

Crustaceans- $\$ 308,000$

Ornamental- $\$ 2,584,000$

Sport fish- $\$ 8,933,000$

- Regulatory Agencies:

1.) Arkansas Game \& Fish Commission (Fisheries Division) (AR GFC),

2.) Arkansas Department of Agriculture (AR DOA)- Lead Agency),

- Commentary:

Aquaculture in Arkansas has been occurring at least since early 1960 with the introduction and production of grass carp. While Arkansas lacks major aquaculture focused legislation, the state industry has managed to thrive on the voluntary participation of its producers. The state follows many of the EPA's requirements for effluent based limitation a guideline for discharge since much of the production is static occurring in ponds rather than traditional flow-through systems. Similarly, animal health certification occurs on a voluntary basis since much production is export-based to meet demand for stock overseas and also in states nearby. Interstate transportation and importation regulation requires certification before export. The state contact was friendly and helpful in disseminating information quickly.

- Sources:

Ted McNulty, Arkansas Department of Agriculture

$1-870-575-8111$

tmnculty@uaex.edu 
Nathan Stone, Fisheries Specialist, University of Arkansas (Pine Bluff)

$1-870-575-8138$

nstone@uaex.edu

North Central Regional Aquaculture Center (NCRAC), Arkansas Importation Regulation, -http://www.ncrac.org/Info/StateImportRegs/arkansas 
California- (CA)

- Applicable Statutes:

Ca. Fish \& Game Code, D.05, Aquaculture.

Cal. Fish \& G. Code \$2116 (Definition).

CA. Fish \& Game Code, D. 12, Aquaculture.

$\S 1700(f)$.

$\S 15001$.

$\S 15101-05$.

$\S 15100$ et seq.

$\S 15500-16$.

$\S 15502-03$.

CA. C.C.P. Pt. 3, T. 13.

Cal. Health \& Safety Code $§ 112165(1)$. $\S 114775$ et seq.

Cal. Fish \& G. Code $\S 6301$. Stats.2007, c. 285 (A.B. 1729), §108.

CA. Fish \& Game Code, D. 12, Aquaculture § 15600-05. $\$ 2270.5$ (w/ exemption provision). $\S 15400$, et seq.

$\S 1123.5$

CA LEGIS 810 (1995)(1).

CA LEGIS, Infra note 276 at 27.

Cal.Pub. Res.Code D.1, Ch.4 Aquaculture Development Act.

CA. Fish \& Game Code, D. 12, Aquaculture § 15700-03. $\S 15800-03$, repealed by Stat. 1995 , c. 810 (A.B. $1636 \S 10$ ).

Cal. Fish \& G. Code $\$ 54.5$.

$\S 61$.

$\S 15900-08$, repealed by Stat. 1995, c. 677 (S.B. $1176 \S 6$ ). $\S 2859(\mathrm{~d})$.

Stats. 1999, c. 1015(A.B. 993), §1, later amended by Stat. 2001, c. 753 (A.B. 1673), §3; Stats.2002, c. 559(A.B.892), §2.

Cal. Fish \& G. Code $§ 5654(a)(1), \&(f)(2)$. $\S 6954$ et seq.

Cal. Fish \& G. Code $§ 7050(4)(7)$. $\S 15400$. $\$ 15411$.

Cal. Water Code $\S 13382.5$

- Other Rules \& Regulation:

14 CCR $§ 165$, (Harvest of Aquatic Plants), $\$ 227$, (Sale of Live Aquaculture Products), $\S 235$, (Aquaculture Registration), $\S 235.2$, (Anadromous Fish Facility Permit) §236, (Importation- Live Aquatic Plants, Mollusks), \$236.1, (Importation of Live Bi-value Mollusks), $\$ 237$, (Leasing Regulation for State Water Bottoms), 
§238, (Sale \& Transportation of Aquatic Plants \& Animals),

$\$ 238$ et seq., (Stocking of aquaculture products),

$\S 239$, (Transportation, Sale of Sturgeon, Striped Bass, Hybrid striped bass),

$\S 240$, (Importation of Salmonids)

\$245, (Aquaculture Disease Control),

\$671.1, (Permits for Restricted Species),

\$671.1, (Permits for aquaculture and fish),

§703, (Misc, Applications, Tags, Licensure)

23 CCR §667, (Aquaculture Use),

$\S 3920$, (Water Quality Control Plans),

- Evaluation Criteria:

1.) Has the State enacted development legislation?- (Yes),

2.) Date of formal legislative enactment?- (1982-1998),

3.) Has the State enacted a development act?- (Yes)

4.) If Yes, when was the development act completed?- (1998),

5.) Has the State completed a development plan?- (No),

6.) If Yes, when was the development plan completed?- (No),

7.) What was the timeframe for completion?- (No),

8.) Does the State have a lead agency?"-(Yes),

9.) Which agency is tead agency?- [California Department of Fish \& Game-(CA DFG)],

10.) Does the State have an aquaculture coordinator/Expert contact?- (Yes),

11.) Does the State have an advisory board/council/committee/task force?- (Yes)[Aquaculture Industry Advisory Committee],

12.) If Yes, does the panel still exist?-(Yes),

13.) Has the State enacted more stringent discharge regulation?- (Yes),

14.) What has the state enacted?- [State Discharge Program],

15.) Has the State enacted more stringent aquatic animal health standards (AAHM)?(Yes),

16.) What is the AAHM regulation?- [State Monitored Facility Certification and Disease Testing Program],

17.) Does the State have higher education participation?-(Yes),

- Wirth \& Luzar (2000) Regulatory Stringency Value: “10"

- Species Cultured:

Aquatic Plants, Catfish, Trout, Salmonids, largemouth bass, striped bass, sturgeon, mollusks, etc. 
- Production Values (2007):

Catfish- $\$ 12,529,000$

Trout- $\$ 17,913,000$

Other food fish- $\$ 20,200,000$

Baitfish- $\$ 1,096,000$

Mollusks- $\$ 11,724,000$

Ornamental- $\$ 13,415,000$

Sport fish/ Game fish- $\$ 3,871,000$

Other products- $\$ 13,835,000$

- Regulatory Agencies:

a.) California Department of Fish \& Game (CA DFG)

b.) California Department of Food \& Agriculture (CA DOA)

c.) California Department of Natural Resources (CA DNR)

- Commentary: industry.

Confusing regulatory history mixed with tremendous redundant regulation for the

- Sources:

Heather McIntire, California Department of Fish \& Game

$1-916-539-2028$

hmcintire@dfg.ca.gov

Duane Schnabel, Senior Agriculture Biologist (Aquaculture Coordinator)

California Department of Food \& Agriculture

$1-916-654-0768$

California Administrative Code-(Rules and Regulation), Search -Aquaculture"

http://weblinks.westlaw.com/result/default.aspx?action=Search\&cfid=1\&db=CA\%2DAD $\mathrm{C} \&$ eq $=$ search $\& \mathrm{fmqv}=\mathrm{s} \& \mathrm{fn}=\% 5 \mathrm{Ftop} \&$ method $=\mathrm{TNC} \&$ origin $=$ Search\&query $=$ AQUACULTURE \&rlt=CLID\%5FQRYRLT32621443014411\&rltdb=CLID\%5FDB64247443014411\&rp=\%2FSea rch\%2Fdefault \%2Ewl\&rs=GVT1\%2E0\&service=Search\&sp=CCR\%2D1000\&srch=TRUE\&ssk ey=CLID $\% 5 F S S S A 80263443014411 \&$ sv $=$ Split\&tempinfo=word\&vr=2\%2E0 
Colorado- $(\mathrm{CO})$

- Applicable Statutes:

C.R.S.A. §24-1-123 (1975)- (Development Declaration),

CO ST §35-24.5-100, (Development Act Legislation)(1991)

$\S 35-24.5-102$, (Aqua is Ag Classification)

\$35-73-103, (AG Development Act,) (1981)

$\S 5-24.5-106$, (Advisory Board),

\$35-24.5-107, (Regulation Tasked)

CO ST §33-4-102, (Permits, Fees, Licensure), $\S 33-5.5-101$, (Aquatic Health Provisions), §33-5.5-102, (Importation Requirements)

- Other Rules \& Regulation:

2 CCR 406-1 Chapter 1- Fishing Regulation

8 CCR 1201-1221, (Administrative Enforcement of Colorado Aquaculture Act)

Chapter 0, Article VII: Aquatic Wildlife Regulation (Colorado Wildlife Commission Regulation) \#010: Transportation of Aquatic Wildlife,

\#011: Importation of Aquatic Wildlife,

\#012: Possession of Aquatic Wildlife,

\#013: Release of Aquatic Wildlife,

\#014: Aquatic Wildlife Health Management

- Evaluation Criteria:

1.) Has the State enacted development legislation?- (Yes),

2.) Date of formal legislative enactment?- (1975-1981),

3.) Has the State enacted a development act?- (Yes),

4.) If Yes, when was the development act completed?- (1981),

5.) Has the State completed a development plan?- (N/A),

6.) If Yes, when was the development plan completed?- (N/A),

7.) What was the timeframe for completion?- (N/A),

8.) Does the State have a tead agency?"- (Yes),

9.) Which agency is tead agency?"- [Colorado Department of Agriculture-(CO DOA)],

10.) Does the State have an aquaculture coordinator/Expert contact?- (Yes),

11.) Does the State have an advisory board/council/committee/task force?(Yes)- [Aquaculture Board],

12.) If Yes, does the panel still exist?- (N/A),

13.) Has the State enacted more stringent discharge regulation?- (Yes),

14.) What has the state enacted? - State Driven Plant wide Discharge Permit Requirements,

15.) Has the State enacted more stringent aquatic animal health standards (AAHM)?-Yes,

16.) What is the AAHM regulation?- State Driven Aquatic Disease Importation Certification Requirements,

17.) Does the State have higher education participation?-Yes, 
- Wirth \& Luzar (2000) Regulatory Stringency Value: "12"

- Species Cultured:

Trout, Bass, Bluegill, Catfish, Grass, Carp, Walleye, Baitfish, etc.

- Production Values (2007):

Catfish- $\$ 12,529,000$,

Trout- $\$ 7,471,000$,

Other Food fish- N/A,

Crustaceans- N/A,

Baitfish- $\$ 181,000$,

Mollusks- N/A,

Sportfish-N/A,

Ornamental- N/A

- Regulatory Agencies:

1.) Colorado Department of Agriculture (CO DOA),

2.) Colorado Department of Natural Resources (CO DNR),

3.) Colorado Division of Wildlife (CO DOW),

- Commentary:

Contact with state regulatory agencies took multiple attempts with limited answers to questions. Colorado has small industry production with tremendous regulatory structure.

- Sources:

Scott Leach, Colorado Department of Agriculture

1-303-239-4295

Scott.leach@ag.state.co.us

Karl Mauch

$1-303-239-5713$

Andrew Ross

$1-303-692-3395$

North Central Regional Aquaculture Center, Colorado Importation Requirements, - http://www.ncrac.org/Info/StateImportRegs/colorado.htm 
Connecticut- $(C T)$

- Applicable Statutes:

C.G.S.A. \$22-11, (Aqua is AG Classification), $\S 22-416$, (Development Declaration), $\$ 22-11(\mathrm{~d}),($ CT DOA Lead Agency), $\S 22-11$ (e), (Inter-agency Aquaculture Coordinating Committee), §22-11(f), (Development legislation) (1998), $\S 22 \mathrm{a}-430$, (Water Pollution Control), \$22a-361-367, (Transportation \& Import/ Export of Products). $\S 10-64-65$, (Research \& Education), $\S 19 a-102$, (Turtle Restriction),

- Other Rules \& Regulation:

$-\mathrm{N} / \mathrm{A}$

- Evaluation Criteria:

1.) Has the State enacted development legislation?- (Yes),

2.) Date of formal legislative enactment?- (1994),

3.) Has the State enacted a development act?- (Yes),

4.) If Yes, when was the development act completed?- (1994),

5.) Has the State completed a development plan?-(Yes),

6.) If Yes, when was the development plan completed?- (1986),

7.) What was the timeframe for completion?- (2Yrs.),

8.) Does the State have a tead agency?"- (Yes),

9.) Which agency is tead agency?"- [ Connecticut Department of Agriculture-(CT DOA)],

10.) Does the State have an aquaculture coordinator/Expert contact?- (Yes),

11.) Does the State have an advisory board/council/committee/task force?(Yes)-[Interagency Aquaculture Coordinating Council],

12.) If Yes, does the panel still exist?- (N/A),

13.) Has the State enacted more stringent discharge regulation?- (Yes),

14.) What has the state enacted?- [State Driven Discharge Permit],

15.) Has the State enacted more stringent aquatic animal health standards (AAHM)?- (Yes),

16.) What is the AAHM regulation?- [State Mandated Facility Certification Requirement for Invasive Species],

17.) Does the State have higher education participation?- (Yes),

- Wirth \& Luzar (2000) Regulatory Stringency Value: —XA"

- Species Cultured:

Shellfish (Oysters, Mussels, Clams), Salmon, Marine Ornamentals, Trout, etc. 
- Production Values (2007):

Catfish- N/A,

Trout- $\$ 3,440,000$,

Other Food Fish- N/A

Baitfish-N/A,

Crustaceans- N/A,

Mollusks- $\$ 11,570,000$,

Ornamentals- N/A,

Sportfish- N/A,

- Regulatory Agencies:

1.) Connecticut Department of Agriculture (CT DOA) - Lead Agency,

2.) Connecticut Department of Environmental Protection (CT DEP),

- Commentary:

Connecticut has a great reference website that is -aquaculture-friendly." Any potential aquaculturist can easily obtain necessary the requirements for industry entry from this site.

- Sources:

David Carey, CT Department of Agriculture,

P: 1-203-874-0696,

davcarey@snet.net

dept.agric@snet.net

Tessa Getchis, Connecticut Sea Grant College Progam

1-860-405-9127

Tessa.getchis@uconn.edu 
Delaware- $(D E)$

- Applicable Statutes:

DE ST T.3, §401, (ADA)(1990)

$\S 403$, (Lead Agency Designation- DE DOA),

$\S 404$, (Marketing Mandate),

$\S 405$, (Aquaculture Marketing Council),

3 DEL. C. $\S 407$, (Non-tidal waters production Regulation), $\$ 409$ (Facility Regulation)

7 DEL. C. $\S 903$, (Permitting) $\S 6010$, (Proposed NPDES)

- Other Rules \& Regulation:

$-\mathrm{N} / \mathrm{A}$

- Evaluation Criteria:

1.) Has the State enacted development legislation?- (Yes),

2.) Date of formal legislative enactment?- (1990),

3.) Has the State enacted a development act?- (Yes)

4.) If Yes, when was the development act completed?- (1990),

5.) Has the State completed a development plan?- (N/A),

6.) If Yes, when was the development plan completed?- (N/A),

7.) What was the timeframe for completion?- (N/A),

8.) Does the State have a lead agency?"- (Yes),

9.) Which agency is tead agency?"- [Delaware Department of Agriculture (DE DOA)],

10.) Does the State have an aquaculture coordinator/Expert contact?- (Yes),

11.) Does the State have an advisory board/council/committee/task force?(Yes)- [Aquaculture Council],

12.) If Yes, does the panel still exist?- (N/A),

13.) Has the State enacted more stringent discharge regulation?- (Yes),

14.) What has the state enacted?- [State Driven Discharge Permit],

15.) Has the State enacted more stringent aquatic animal health standards (AAHM)?- (N/A),

16.) What is the AAHM regulation?- (N/A),

17.) Does the State have higher education participation?-(Yes),

- Wirth \& Luzar (2000) Regulatory Stringency Value: “5”

- Species Cultured:

Catfish, Crappie, Koi, Largemouth, Smallmouth, \& Striped Bass, Sunfish, Tilapia, Yellow Perch, Various Minnows \& Baitfish, Oysters, Speckled Trout, etc. 
- Production Values (2007):

Catfish-N/A,

Trout- N/A,

Other Food Fish- N/A,

Baitfish-N/A,

Crustaceans- N/A,

Mollusks- N/A,

Ornamentals- N/A,

Sportfish- N/A,

- Regulatory Agencies:

1.) Delaware Department of Agriculture (DE DOA) - Lead Agency,

2.) Delaware Department of Natural Resources \& Environmental control (DE DNR),

3.) Delaware Department of Fish and Wildlife (DE DFW)

- Commentary:

Delaware is a relatively small industry as a whole. However, its location to nearby major cities in the U.S. should increase the marketability of its marine food fish production.

- Sources:

Dr. John Ewart, University of Delaware, (Aquaculture Resources Center) $1-302-645-4060$

ewart@udel.edu

G. Robert Moore, DE Department of Agriculture, (Aquaculture Coordinator)

1-302-698-4566

Robert.moore@state.de.us

Delaware Aquaculture Act,

- http://delcode.delaware.gov/title3/c004/

McIntosh, D., \& Ewart, J. (2009). Aquaculture sitation and Outlook Report 2009:

Delaware. College Park, MD: University of Maryland. 
Florida- $(F L)$

- Applicable Statutes:

F.S.A. $\$ 187.201$, (Comprehensive Plan)

$\$ 253.68-.69$,

$\S 161.73$,

$\S 161.74$,

$\S 161.231$, (AG Exemption),

$\S 258.42$,

$\$ 373.4595$, (Water Resources Legislation)

$\$ 376$ et seq. (Pollutant Discharge Prevention and Control Act)

\$379.2521, (Marine Aquaculture Regulation),

$\$ 379.2523$, (Saltwater Licensure)

$\$ 597.001-020$, (Aquaculture Policy Act)

$\$ 597.003$, (Lead Agency Designation- FL DOA)

\$597.004, (Certification/ Registration),

$\$ 597.005$, (Aquaculture Review Council),

\$597.006, (State Interagency Coordinating Council),

$\$ 597.010$, (Shellfish regulation),

\$57.020, (Shellfish Processor Regulation)

FL ST $\S 403.0885$, (NPDES),

\$403.814, (General NPDES Permits),

\$403.927, (Storm water Exemption),

\$570.061, (Aquaculture Division in FLDOA)

- Other Rules \& Regulation:

5L-1, (Comprehensive Shellfish Control Code),

5L-3, (Aquaculture Best Management Practices),

18-21, (Sovereignty submerged lands management policy)

- Evaluation Criteria:

1.) Has the State enacted development legislation?- (Yes),

2.) Date of formal legislative enactment?- (1985),

3.) Has the State enacted a development act?- (Yes),

4.) If Yes, when was the development act completed?- (1984),

5.) Has the State completed a development plan?- (Yes),

6.) If Yes, when was the development plan completed?- (1985),

7.) What was the timeframe for completion? - (2 Yrs.),

8.) Does the State have a tead agency?"-(Yes),

9.) Which agency is — lad agency?"

- [Florida Department of Agriculture- (FL DOA)],

10.) Does the State have an aquaculture coordinator/Expert contact?- (Yes),

11.) Does the State have an advisory board/council/committee/task force?-

(Yes) [Aquaculture Review Council],

12.) If Yes, does the panel still exist?- (N/A),

13.) Has the State enacted more stringent discharge regulation?- (Yes), 
14.) What has the state enacted?- [State Driven NPDES Program],

15.) Has the State enacted more stringent aquatic animal health standards (AAHM)?- (N/A),

16.) What is the AAHM regulation?- [Best Management Practice (BMP's) enforced by APHIS],

17.) Does the State have higher education participation?- (Yes),

- Wirth \& Luzar (2000) Regulatory Stringency Value: “2”

- Species Cultured:

Catfish, trout, ornamental, baitfish, alligators, aquatic plants, sturgeon, clams, etc.

- Production Values (2007):

Catfish- $\$ 979,000$

Other food fish- $\$ 3,412,000$

Baitfish- $\$ 71,000$

Crustaceans- $\$ 2,520,000$

Mollusks- $\$ 15,251,000$

Ornamental- $\$ 32,192,000$

Sport fish/ Game fish- $\$ 622,000$

- Regulatory Agencies:

1.) Florida Department of Agriculture (FL DOA) - Lead Agency,

2.) Florida Fish \& Wildlife Conservation Commission (FL FWC),

3.) Florda Department of Fish and Wildlife (FL DFW),

4.) Florida Department of Environmental Protection (FL DEP)

- Commentary:

Due to an overabundance of readily available information for use by the public, Florida's industry promotion often receives praise. Its information dissemination model utilizes an extension service with multiple locations and contact personnel to distribute and promote all matters aquaculture throughout the state. Florida's active promotion is largely to credit for its booming ornamental production industry. Though the state lacks a centralized processor for food fish production, its tropical production balances its shortcomings.

- Sources:

Paul Zajicek, Florida Department of Agriculture (Aquaculture)

1-850-488-5471

Paul.Zajicek@,freshfromflorida.com

Florida Administrative Code, Search -Aquacultue Regulation" https://www.flrules.org/gateway/result.asp 
Georgia- (GA)

- Applicable Statutes:

GA. Code Ann. §2-15-1, (Pacific Shrimp Aquaculture Development Act)

§2-15-4, (Inspection Requirement),

$\S 2-15-6$, (Registration Requirement),

\$12-5-31, (Water Use Permitting)

\$15-5-288, (Economic Development Provisions)

\$391-4-14-.01-.03, (Aquaculture - GADNR)

GA. Code Ann, T.27, Ch.4, (ADA)

§27-4-253, (Aquaculture Development Commission),

$\$ 27-4-255$, (Registration req.),

\$27-4-262, (Rules/ Regs of GA DNR),

$\$ 27-4-263$, (Inspection Mandate)

- Other Rules \& Regulation:

391-4-14-.01 Application for Aquaculture Registration, 391-4-14-.02 Disqualification or Revocation.

391-4-14-.03 Registration Certificates.

- Evaluation Criteria:

1.) Has the State enacted development legislation?- (Yes),

2.) Date of formal legislative enactment?- (1996-2008),

3.) Has the State enacted a development act?-(Yes),

4.) If Yes, when was the development act completed?- (2008),

5.) Has the State completed a development plan?- (Yes),

6.) If Yes, when was the development plan completed?- (1996),

7.) What was the timeframe for completion? - (4 Yrs.),

8.) Does the State have a tead agency?"- (Yes),

9.) Which agency is tead agency?"- [Georgia Department of Natural Resources(GA DNR)],

10.) Does the State have an aquaculture coordinator/Expert contact?- (Yes),

11.) Does the State have an advisory board/council/committee/task force?(Yes)- [Aquaculture Focused Development Commission],

12.) If Yes, does the panel still exist?- (N/A),

13.) Has the State enacted more stringent discharge regulation?- (N/A),

14.) What has the state enacted?- [(BMP'S) Program for Discharge],

15.) Has the State enacted more stringent aquatic animal health standards (AAHM)?- (N/A),

16.) What is the AAHM regulation?- [(BMP's) Program for AAHM],

17.) Does the State have higher education participation?-(Yes),

- Wirth \& Luzar (2000) Regulatory Stringency Value: +10

- Species Cultured:

Catfish, Trout, Freshwater Prawns, etc. 
- Production Values:

Catfish- $\$ 1,313,000$

Trout- $\$ 1,629,000$

Other Food fish- $\$ 369,000$

Crustacean- $\$ 44,000$

Mollusks- $\$ 450,000$

Ornamental- $\$ 92,000$

Sport fish/ Game fish- $\$ 984,000$

- Regulatory Agencies:

1.) Georgia Department of Agriculture (GA DOA),

2.) Georgia Department of Natural Resources (GA DNR)- Lead Agency

- Commentary:

Political influence has altered the course of development for this state industry. Originally, under strong legislative backing, the state pacific shrimp development program was heavily vested to fully develop the industry in Georgia, then due to fiscal appropriation all of the legislature's investment resulted in wasted legislation that never allowed aquaculture to reach its maximum potential. The resulting development legislation promoted by the GADNR applies solely to fish aquaculture represent a renewed interest in this industry.

- Sources:

Michael Spencer, Georgia Department of Natural Resources

1-770-918-6406

Michael_spencer@dnr.state.ga.us

Randy Walker, University of Georgia, (Marine Extension Expert)

1-706-542-8838

walker@uga.edu

Georgia Aquaculture Development Plan (1996),

http://warnell.forestry.uga.edu/service/library/index.php3?docID $=33 \&$ docHistory $\% 5 \mathrm{~B} \% 5$

$\underline{\mathrm{D}=1}$

Georgia Administrative Rules and Regulations,

http://rules.sos.state.ga.us/cgi-bin/search.cgi?d=1\&query=aquaculture 
Hawaii- (HI)

- Applicable Statutes:

HHCA Const. Art. §11-6, (Condemnation for Agriculture Development), $\$ 207$, (Residential Agriculture Development Promotion), \$219-220, (Aquaculture -xpert” appropriation (1921)), $\S 221$, (Access to government owned waters), $\S 171-36$, (Leasing Program for Agricultural Sectors), $\S 174$, (Water Code), \$26-16 et seq., (Aquaculture Development, HI DOA), \$141, (Aquaculture Codified), §148D, (Aquaculture Advisory Council)- Now Repealed, §187A1-3.5, (Aqua cultural Enterprise Regulation), $\$ 201-19$ et seq., (Economic Development Program), $\S 205-2$ et seq., (Land Use Restriction), $\S 190 \mathrm{D}$ et seq., (Submerged lands leasing program), $\S 219$ et seq., (Fiscal Access provisions),

HRS §302A-431.7et seq. (Education Promotional Program), $\S 344$, (HEPA- NEPA Variant Provisions),

- Other Rules \& Regulation:

Aquaculture Loan Program $\S 4-9-1$ Rules,

§4-9-2 Purpose and intent, $\S 4-9-3$ Definitions, $\S 4-9-4$ Loan; eligibility, $\S 4-9-5$ Restrictions, §4-9-6 Application procedure, §4-9-7 Conditions, §4-9-8 Security for loans, $\S 4-9-9$ Interest rate, $\S 4-9-10$ Disbursements, \$4-9-11 Repayment; refinancing, $\S 4-9-12$ Appraisals, §4-9-13 Administration, Aquaculture Development Special Fund- §4-170-1 Purpose, \$4-170-2 Definitions, $\S 4-170-3$ Fees for Diagnostic Services, $\S 4-170-4$ Fee for Certificate of Health, $\S 4-170-5$ Fees for Technical Services, $\S 4-170-6$ Waiver, $\S 4-170-7$ Development Special Fund, 
- Evaluation Criteria:

1.) Has the State enacted development legislation?- (Yes),

2.) Date of formal legislative enactment?- (1959-1981),

3.) Has the State enacted a development act?- (Yes),

4.) If Yes, when was the development act completed?- (1981),

5.) Has the State completed a development plan?- (Yes),

6.) If Yes, when was the development plan completed?- (1979),

7.) What was the timeframe for completion? - (2 Yrs.),

8.) Does the State have a tead agency?"- (Yes),

9.) Which agency is tead agency?"- [Hawaii Department of Agriculture- (HI DOA)],

10.) Does the State have an aquaculture coordinator/Expert contact?- (Yes),

11.) Does the State have an advisory board/council/committee/task force?(Yes)- [Aquaculture Advisory Council],

12.) If Yes, does the panel still exist?- (N/A),

13.) Has the State enacted more stringent discharge regulation?- (Yes),

14.) What has the state enacted?- [Water Use Permits],

15.) Has the State enacted more stringent aquatic animal health standards (AAHM)?- (Yes),

16.) What is the AAHM regulation?- [Importation Requirements],

17.) Does the State have higher education participation?-(Yes),

- Wirth \& Luzar (2000) Regulatory Stringency Value: “8”

- Species Cultured:

Yellowtail, Pacific Threadfin, Yellow fin Tuna, Algae, Catfish, etc.

- Production Values (2007):

Catfish- $\$ 116,000$,

Trout- N/A,

Other Food Fish- $\$ 4,513,000$,

Baitfish- N/A,

Crustaceans- $\$ 4,057,000$,

Mollusks- N/A,

Ornamental- $\$ 2,418,000$,

Sportfish- N/A,

- Regulatory Agencies:

1.) Hawaii Department of Agriculture (HI DOA),

- Commentary:

Hawaii for three decades has always been considered an agricultural progressive state. This idea comes from the understanding that the state as a barrier island must either import or grow its food. Therefore, for almost a century, Hawaii has utilized some form of aquaculture to produce its fish products for its people. Today, many states create industries based on their development model and outreach program through the HI DOA. 
- Sources:

Todd Low, HI Department of Agriculture, (Aquaculture Development Program) 1-808-483-7130

Todd.e.low@hawaii.gov

Hawaii Administrative Rules and Regulations, http://hawaii.gov/hdoa/admin-

rules/Aquaculture\%20Development $\% 20$ Special $\% 20$ Fund $\% 20$ Admin $\% 20$ Rules.pdf 
Idaho- (ID)

- Applicable Statutes:

I.C. §22-103, (Legislative Declaration of Aquaculture),

$\$ 22-1102$, (Organic Food Code Acknowledgment),

$\$ 22-4401-4409$ et seq., (Aquaculture Commission),

$\S 22-4603$, (Facility Management Licensure, AAHM),

$\$ 39-118$ et seq., (Animal Waste Provisons),

\$39-3602, (Water Oversight Regulation),

$\S 42-706$, (Water Management Districts)

- Other Rules \& Regulation:

$-\mathrm{N} / \mathrm{A}$,

- Evaluation Criteria:

1.) Has the State enacted development legislation?- (Yes),

2.) Date of formal legislative enactment?- (1992-1994),

3.) Has the State enacted a development act?- (Yes),

4.) If Yes, when was the development act completed?- (1994),

5.) Has the State completed a development plan?- (N/A),

6.) If Yes, when was the development plan completed?- (N/A),

7.) What was the timeframe for completion?- (N/A),

8.) Does the State have a lead agency?"- (Yes),

9.) Which agency is tead agency?"- [Idaho Department of Agriculture- (ID DOA)],

10.) Does the State have an aquaculture coordinator/Expert contact?- (Yes),

11.) Does the State have an advisory board/council/committee/task force?(Yes)- [Agriculture Development Council],

12.) If Yes, does the panel still exist?- (N/A),

13.) Has the State enacted more stringent discharge regulation?- (Yes),

14.) What has the state enacted?- [NPDES Discharge Permit],

15.) Has the State enacted more stringent aquatic animal health standards (AAHM)?- (Yes),

16.) What is the AAHM regulation?- [State Monitored Inspection and Certification Requirement],

17.) Does the State have higher education participation?- (Yes),

- Wirth \& Luzar (2000) Regulatory Stringency Value: “12"

- Species Cultured:

Trout, etc. 
- Production Values (2007):

Catfish- N/A,

Trout- $\$ 53,782,000$,

Other Food fish- $\$ 1,895,000$,

Baitfish- N/A,

Crustaceans- N/A,

Mollusks- N/A,

Ornamentals- N/A,

Sportfish- N/A,

Other- $\$ 96,000$

- Regulatory Agencies:

1.) ID Department of Agriculture (ID DOA),

2.) ID Department of Environmental Quality (ID DEQ),

3.) ID Department of Natural Resources (ID DNR),

4.) ID Department of Water Resources (ID DWR),

5.) ID Department of Fish \& Game (ID DFG)

- Commentary

- Trout is king in Idaho!

- Sources:

Debra Lawrence, ID Department of Agriculture

1-208-332-8540

Debra.lawrence@agri.idaho.gov 
Illinois- (IL)

- Applicable Statutes:

20 ILCS 205/ 205-60, (Aquaculture)

215/ 1, (ADA),

215/5, (Lead Agency- IL DOA),

215/6, (Advisory Committee)

55 ILCS 215/5.5,

17 ILCS $\$ 870.50$,

25 ILCS, Act. 225

415 ILCS 60/4,

505 ILCS 5/3.02 et seq.,

$19 / 5$,

515 ILCS 5/10-10.5 et seq., (IL DNR Importation Req.),

5/5-5, (Permits),

5/20-90, (Aquaculture Facility Regulation)

- Other Rules \& Regulation:

Administrative Code 805: Injurious Species,

810: Sport fishing regulation,

870: Aquaculture, Transportation, Importation, \& Possession

875: Viral Hemorrhagic Septicemia (VHS)

890: Fish Removal Using Chemicals,

- Evaluation Criteria:

1.) Has the State enacted development legislation?- (Yes),

2.) Date of formal legislative enactment?- (1988),

3.) Has the State enacted a development act?- (Yes),

4.) If Yes, when was the development act completed?- (1988),

5.) Has the State completed a development plan?- (Yes),

6.) If Yes, when was the development plan completed?-(1987),

7.) What was the timeframe for completion? - (2 Yrs.),

8.) Does the State have a tead agency?"- (Yes_,

9.) Which agency is tead agency?"- [Illinois Department of Agriculture- (IL DOA)],

10.) Does the State have an aquaculture coordinator/Expert contact?(Yes),

11.) Does the State have an advisory board/council/committee/task force?- (Yes)- [Aquaculture Advisory Committee],

12.) If Yes, does the panel still exist?-N/A,

13.) Has the State enacted more stringent discharge regulation?- (N/A),

14.) What has the state enacted?- (N/A),

15.) Has the State enacted more stringent aquatic animal health standards (AAHM)?- (Yes),

16.) What is the AAHM regulation?- [State Importation Requirements], 
17.) Does the State have higher education participation?- (Yes),

- Wirth \& Luzar (2000) Regulatory Stringency Value: "4”

- Species Cultured:

Catfish, Trout, etc.

- Production Values (2007):

Catfish- $\$ 115,000$,

Trout- N/A,

Baitfish- \$1,895,000,

Crustaceans- $\$ 7,000$,

Mollusks- N/A,

Other Food fish- $\$ 284,000$

Sport fish/ Game fish- \$2,235,000

- Regulatory Agencies:

1.) IL Department of Agriculture (IL DOA)- Lead Agency,

2.) IL Department of Natural Resources (IL DNR),

3.) IL Department of Environmental Quality (IL DEQ),

- Commentary:

Biosecurity is primary focus to protect Illinois aquaculture stock from pathogen contamination. The state industry has published many primers on prevention measures for producers from VHS.

- Sources:

Delayne Reeves, IL Department of Agriculture (Aquaculture Coordinator)

1-217-524-9129

Delayne.reeves@illinois.gov

Illinois Aquaculture Biosecurity Manual (2010),

-http://fishdata.siu.edu/secure/bioman.pdf 
Indiana- (IN)

- Applicable Statutes:

IN ST 4-4-3.8, (Aquaculture Chapter),

4-4-3.8(2), (Duties),

4-4-3.8(3), (Financial Assistance),

4-4-15(7), (Indiana Financial Development Authority),

15-16-10-5, (Invasive Species Control Council),

15-11-7-1, (Revised Aquaculture Chapter),

15-11-7-4, (Revised Duties),

15-7-2-26 et seq., (Domestic Animal Classification),

IC 14-22-6, (Bait Dealers License),

IAC 9-10-15, (Fish Importation Permit),

9-10-17, (General Aquaculture Permit),

312 IAC 9-10-7, (Fish Hauler \& Supplier Permits),

9-10-8, (IN Fish stocking Permits),

- Other Rules \& Regulation:

$-\mathrm{N} / \mathrm{A}$,

- Evaluation Criteria:

1.) Has the State enacted development legislation?- (Yes),

2.) Date of formal legislative enactment?- (1995-1997),

3.) Has the State enacted a development act?- (Yes),

4.) If Yes, when was the development act completed?- (N/A),

5.) Has the State completed a development plan?- (Yes),

6.) If Yes, when was the development plan completed?- (1997),

7.) What was the timeframe for completion? - (2 Yrs.),

8.) Does the State have a tead agency?"- (Yes),

9.) Which agency is tead agency?"- [Indiana Department of Agriculture- (IN DOA)],

10.) Does the State have an aquaculture coordinator/Expert contact?(Yes),

11.) Does the State have an advisory board/council/committee/task force?- (Yes)- [Invasive Species Control Council],

12.) If Yes, does the panel still exist?- (N/A),

13.) Has the State enacted more stringent discharge regulation?- (Yes),

14.) What has the state enacted?- [State Driven NPDES Program],

15.) Has the State enacted more stringent aquatic animal health standards (AAHM)?- (Yes),

16.) What is the AAHM regulation?- [Invasive Species Inventory \& Importation Certification Requirement],

17.) Does the State have higher education participation?- (Yes),

- Wirth \& Luzar (2000) Regulatory Stringency Value: —XA" 
- Species Cultured:

Catfish, Trout, Baitfish, Freshwater Mollusks \& Crustaceans, etc.

- Production Values (2007):

Catfish-\$145,000,

Trout- N/A,

Other Food Fish- $\$ 573,000$,

Baitfish- $\$ 7,000$,

Crustacean-N/A,

Mollusk-N/A,

Ornamental-N/A,

Sport fish/ Game fish- $\$ 581,000$

- Regulatory Agencies:

1.) Indiana Department of Agriculture (IN DOA)-(Lead Agency),

2.) Indiana Department of Natural Resources (IN DNR),

- Commentary:

- Like Hawaii and Florida, Indiana has taken the initiative to create an efficient website for the IN DNR to disseminate information to the public. Here inquiry into permits and licensure can be addressed for all compliance regulation. By having this information readily available, the state has reduced the energy (i.e. time and money) expenditure for potential aquaculturists seeking to either remain in compliance or choose to start-up an aquaculture enterprise. West Virginia would benefit from developing a structured information —deot" such as Indiana.

- Sources:

Dr. Kwamena Quagrainie, Purdue University School of Agriculture

1-765- 494-4200

kquagrai@purdue.edu

Martha Render, Indiana Aquaculture Association

1-219-275-8851

1hoosiers@ffni.com

Indiana Department of Natural Resources Website (Permits and Commercial Licensure), http://www.in.gov/dnr/fishwild/2371.htm

North Central Regional Aquaculture Center (NCRAC), Indiana Aquaculture Regulation, http://www.ncrac.org/Info/StateImportRegs/indiana.htm\#baitfish

Indiana State Board of Animal Health (Veterinary Advisory- State Importation Requirements for Fish),

http://www.ncrac.org/NR/rdonlyres/EA92F3E7-9944-43CE-9737-

436D3070FA33/77635/ImportVetadvy20707.pdf 
Iowa- (IA)

- Applicable Statutes:

I.C.A. $§ 175(\mathrm{~K})$, (Aquaculture is Agriculture Designation) (1980).

$\S 481$ A.2, (Ownership IA DNR),

§481A.141, (Licensure),

$\S 481$ A.142, (Aquaculture License),

\$481A.144-.145 et seq., (Bait Dealers Licensure),

$\S 483$ A.1 et seq., (Aquaculture unit licensure)

- Other Rules \& Regulation:

Administrative Code 517-577.2 et seq., (Harvest of Threatened or Endangered Species Listing)

571-89.1(481A), (Approved Aquaculture Species Listing), 571-89.3(2), (Reportable Diseases), 571-89.3(3), (Inspection)

- Evaluation Criteria:

1.) Has the State enacted development legislation?- (Yes),

2.) Date of formal legislative enactment?- (1992),

3.) Has the State enacted a development act?- (N/A),

4.) If Yes, when was the development act completed?- (N/A),

5.) Has the State completed a development plan?- (N/A),

6.) If Yes, when was the development plan completed?- (N/A),

7.) What was the timeframe for completion?- (N/A),

8.) Does the State have a tead agency?"- (Yes),

9.) Which agency is tead agency?"-[-Joint" Iowa Department of Agriculture (IA DOA) \& Iowa Department of Natural Resources (IA DNR)],

10.) Does the State have an aquaculture coordinator/Expert contact?- (Yes),

11.) Does the State have an advisory board/council/committee/task force?(N/A),

12.) If Yes, does the panel still exist?- (N/A),

13.) Has the State enacted more stringent discharge regulation?- (N/A),

14.) What has the state enacted?- (N/A),

15.) Has the State enacted more stringent aquatic animal health standards (AAHM)?- (N/A),

16.) What is the AAHM regulation?- (N/A),

17.) Does the State have higher education participation?- (Yes),

- Wirth \& Luzar (2000) Regulatory Stringency Value: “9”

- Species Cultured:

Catfish, Trout, Minnows, Perch, Pike, Herring, Suckers, Sunfish, Bass, etc. 
- Production Values (2007):

Catfish- $\$ 270,000$,

Trout- $\$ 633,000$,

Other Food fish- $\$ 22,000$,

Baitfish- $\$ 55,000$,

Crustacean- N/A,

Mollusk- N/A,

Ornamental- N/A,

Sport fish/ Game fish- $\$ 1,381,000$

- Regulatory Agencies:

1.) Iowa Department of Natural Resources (IA DNR),

2.) Iowa Department of Agriculture (IA DOA)

- Commentary:

While no formal designation exists to assert which regulatory agency is the principal agency in Iowa, research suggest the IA DNR acts as lead agency based on its involvement with licensure and permitting. Originally the state classified aquaculture as a form of agriculture, but the majority of regulation appears to come from the IA DNR.

- Sources:

Rich Clayton, Aquaculture Specialist, Department of Natural Resource Ecology and

Management, Iowa State University

$1-515-294-8616$

rclayton@iastate.edu

\section{Iowa Aquaculture Association}

www.iowafishfarmers.com/

Iowa Natural Resources Commission, Approved Species List, Chapter 89 Aquaculture, http://www.legis.state.ia.us/Rules/2001/iac/571 iac/57189/57189.pdf\#xml=http://staffweb. legis.state.i 
$\operatorname{Kansas}(K S)$

- Applicable Statutes:

KS ST 47-1905, (Aquaculture Chapter),

47-1902, (Lead Agency-KSDOA)

47-1905, (Financial Funding),

47-1903-1904 et seq. (Advisory Council) now repealed.

- Other Rules \& Regulation:

KAN.ADMIN.REGS. §115-18-10, (Importation \& Transportation of Aquatic Animals), $\S 115-18-10$, (Prohibited Species Listing), \$32-974, (Private Water Fishing Impoundment), 115-17-(2-14) et seq., (Commercial Aquaculture Permits)

- Evaluation Criteria:

1.) Has the State enacted development legislation?- (Yes),

2.) Date of formal legislative enactment?- (1992),

3.) Has the State enacted a development act?- (Yes),

4.) If Yes, when was the development act completed?- (1992),

5.) Has the State completed a development plan?- (N/A),

6.) If Yes, when was the development plan completed?- (N/A),

7.) What was the timeframe for completion?- (N/A),

8.) Does the State have a tead agency?"-(Yes),

9.) Which agency is tead agency?"- [Kansas Department of Agriculture (KS DOA)],

10.) Does the State have an aquaculture coordinator/Expert contact? - Yes,

11.) Does the State have an advisory board/council/committee/task force?(Yes)- [Aquaculture Advisory Council],

12.) If Yes, does the panel still exist?-(No- Repealed),

13.) Has the State enacted more stringent discharge regulation?- (No),

14.) What has the state enacted?- [Follows Federal NPDES Mandates],

15.) Has the State enacted more stringent aquatic animal health standards (AAHM)?- (N/A),

16.) What is the AAHM regulation?- (N/A),

17.) Does the State have higher education participation?- (Yes),

- Wirth \& Luzar (2000) Regulatory Stringency Value: “3”

- Species Cultured:

Bluegill, Catfish, Trout, etc.

- Production Values (2007):

Catfish- $\$ 458,000$,

Trout- N/A,

Other Food fish- $\$ 57,000$,

Baitfish- N/A, 
Crustaceans- $\$ 13,000$,

Mollusks- N/A,

Ornamental- N/A,

Sport fish/ Game fish- $\$ 1,476,000$

- Regulatory Agencies:

1.) Kansas Department of Agriculture (KS DOA),

2.) Kansas Department of Wildlife, Parks, \& Tourism (KS DWP)

- Commentary:

The majority of production in the state of Kansas occurs as a means fulfilling recreational restocking needs. The lack of food fish market infrastructure drastically affects the production potential for the state. Overall, Kansas is a small aquaculture production state.

- Sources:

Randy Nelson, KS Department of Wildlife \& Parks

$1-620-326-4166$

randyn@wp.state.ks.us

Kansas Aquaculture Association

www.kansasaquaculture.org/

North Central Regional Aquaculture Center (NCRAC), Kansas Aquaculture Regulation, http://www.ncrac.org/Info/StateImportRegs/kansas.htm

Kansas Aquaculture Strategic Development Plan, http://www.kansasaquaculture.org/documents/ksaquaculturestrategydevelopment.pdf 
Kentucky- $(K Y)$

- Applicable Statutes:

KRS T. XXI Ch. $246 \& 247, \S 1$ - (Aquaculture Task Force),

KY ST §260.960, (Aquaculture Development Chapter), $\$ 260.960(3),($ Lead Agency Designation), $\$ 132.010$ et seq., $\S 132.480$ et seq., $\S 148.840$ et seq., 200 KAR 35: 200,

- Other Rules \& Regulation:

$-\mathrm{N} / \mathrm{A}$,

- Evaluation Criteria:

1.) Has the State enacted development legislation?- (Yes),

2.) Date of formal legislative enactment?- (1998-2002),

3.) Has the State enacted a development act?- (Yes),

4.) If Yes, when was the development act completed?- (2001),

5.) Has the State completed a development plan?- (N/A),

6.) If Yes, when was the development plan completed?- (N/A),

7.) What was the timeframe for completion?- (N/A),

8.) Does the State have a tead agency?"-(Yes),

9.) Which agency is tead agency?"- [Kentucky Department of Agriculture (KY DOA)],

10.) Does the State have an aquaculture coordinator/Expert contact?- (Yes),

11.) Does the State have an advisory board/council/committee/task force?(Yes)- [KY Aquaculture Task Force],

12.) If Yes, does the panel still exist?- (N/A),

13.) Has the State enacted more stringent discharge regulation?- (No),

14.) What has the state enacted?- [Follows Federal NPDES Mandate],

15.) Has the State enacted more stringent aquatic animal health standards (AAHM)?- (Yes),

16.) What is the AAHM regulation?- [State Importation/ Exportation Certification Requirements],

17.) Does the State have higher education participation?- (Yes),

- Wirth \& Luzar (2000) Regulatory Stringency Value: “3”

- Species Cultured:

Baitfish, Bass, Bluegill, Carp, Catfish, Crappie, Paddlefish, Trout, Walleye, Tilapia, Sturgeon, Crayfish, Freshwater Prawns, etc. 
- Production Values (2007):

Catfish- $\$ 579,000$,

Trout- N/A,

Other Food fish- $\$ 32,000$

Crustacean- $\$ 96,000$,

Mollusks- N/A,

Ornamental-N/A,

Sport fish/ Game fish- $\$ 1,145,000$

- Regulatory Agencies:

1.) KY Department of Agriculture (KY DOA) (Lead Agency)

- Commentary:

Originally Kentucky has a central processor for the industry, but due to a lack of infrastructure, the processor failed. This outcome mimics West Virginia.

- Sources:

Angela Caporelli, KY Department of Agriculture, (Aquaculture Coordinator) 1-502-564-4983

Angela.caporelli@ky.gov 
Louisiana- (LA)

- Applicable Statutes:

LSA-R.S. 3:262, (State Agriculture Finance Act

3:559 (et seq.), (LA Aquaculture Development ACT)

3:559(4-5), (LA Aquaculture coordinating council)

3:2091, (Louisiana Board of Animal Health),

3:2358.1, (Turtle Management),

3:4502 (LA Product disparagement Control),

3:4732 (Catfish Marketing Law),

9:1104, (Riparian Ownership, Use of Surface waters),

49:214.21, (CZM provisions),

49:214.34, (CZM Use- Permits),

214:34(3), (CZM Use Permits),

56:360, (Louisiana Task Force on Aquatic Invasive Species),

56:412, (Issuance/ Permits),

56:413, (Harvest/ Sale),

$56: 327$,

LA LEGIS 865 (2004), Originally §559.4).

- Other Rules \& Regulation:

$-\mathrm{N} / \mathrm{A}$,

- Evaluation Criteria:

1.) Has the State enacted development legislation?- (Yes),

2.) Date of formal legislative enactment?- (2003),

3.) Has the State enacted a development act?- (Yes),

4.) If Yes, when was the development act completed?- (2003),

5.) Has the State completed a development plan?- (Yes),

6.) If Yes, when was the development plan completed?- (2000),

7.) What was the timeframe for completion?- (5-10Yrs.),

8.) Does the State have a tead agency?"- (Yes),

9.) Which agency is tead agency?"- [Louisiana Department of Agriculture (LA DOA)],

10.) Does the State have an aquaculture coordinator/Expert contact?(Yes),

11.) Does the State have an advisory board/council/committee/task force?- (Yes)- [LA Aquaculture Task Force]

12.) If Yes, does the panel still exist?- (N/A),

13.) Has the State enacted more stringent discharge regulation?- (No),

14.) What has the state enacted?- [Follows Federal Discharge Guidelines],

15.) Has the State enacted more stringent aquatic animal health standards (AAHM)?- (Yes), 
16.) What is the AAHM regulation?- [State Requirement for Transportation \& Importation of Live Cultured Specimens],

17.) Does the State have higher education participation?- (Yes),

- Wirth \& Luzar (2000) Regulatory Stringency Value: “7”

- Species Cultured:

Catfish, crawfish, alligators, oysters, tilapia, baitfish, bass, crabs, and turtles etc.

- Production Values (2007):

Catfish- $\$ 579,000$,

Trout- N/A,

Other Food fish- $\$ 32,000$,

Baitfish- N/A,

Crustacean- $\$ 96,000$,

Mollusk- N/A,

Ornamentals- N/A,

Sport fish/ Game fish- \$1,145,000,

- Regulatory Agencies:

1.) LA Department of Agriculture (LA DOA) Lead Agency,

2.) LA Department of Wildlife and Fisheries (LA DWF),

- Commentary:

In 2003 a legislative surge attempted to promote the establishment of an aquaculture advisory council, later to be vetoed by the Governor. By 2004, support regarding additional legislation culminated into a piece of legislation that based on expert opinions has not changed industry status.

- Source:

C. Greg Lutz, LA State University (Specialist/ Professor),

P: $1-225-765-2848$

glutz@agctr.lsu.edu 
Maine- (ME)

- Applicable Statutes:

5 MRSA $§ 3331$ et seq. (Land \& Water Resources Council).

7 MRSA $\S 125$ et seq. (Board of Agriculture),

$\S 4214$, (Nutrient Management Plan, Waste Discharge"),

$\S 401-404$, (Agriculture Marketing Program),

10 MRSA $\$ 947$, (Economic Development Fund),

12 MRSA $§ 12004$, (Aquaculture Advisory Council),

$\S 13141$ et seq. (Maine Aquaculture Innovations Center),

$\S 15301,($ State Technology Institute),

$\S 6085$, (License Marine Organisms),

$\$ 6071$, (Importation of Live Marine Organisms),

$\$ 6072$ et seq., (Research \& Aquaculture Leases),

$\S 6074$, (Specialty Licensure),

$\S 6075$, (Pathology Program),

$\S 6076$, (Shellfish Health Program),

$\S 6077$, (Aquaculture Monitory Program),

$\S 6078$, (Antibiotic Regulation),

$\S 6080$, (Advisory Council),

$\S 6081$, (Research Council),

§6073, (Municipal Shellfish Permit),

§1872, (Submerged/ Intertidal Lands Exemption),

$\S 6601$, (Commercial Licensure),

$\S 6306$,

38 MRSA §413, (Waste Discharge Licenses),

- Other Rules \& Regulation:

ME DMR Rules-Ch. 1 Watercraft Excise Tax Decal

- Ch. 2 Aquaculture Lease Regulations

- $\underline{\text { Ch. } 3}$ Foreign Fish Processing within Maine's Territorial Sea

- $\underline{\text { Ch. } 4}$ Certification, Recertification, Revocation of Certification for Municipal Shellfish Conservation Warden

- $\quad$ Ch. 5 Confidentiality of Fisheries Statistics

- $\quad$ Ch. 6 Lobster Processing

- $\underline{\text { Ch. } 7}$ Requirements for Municipalities Having Shellfish Conservation Programs

- Ch. 8 Landings Program

- $\quad$ Ch. 9 Harvester: Shellstock Harvesting, Handling and Sanitation

Ch. 10 Clams and Quahogs

Ch. 11 Scallops

- $\quad$ Ch. 12 Mussels

- Ch. 13 Whelks and Periwinkles

- Ch. 14 Oyster Regulations

- Ch. 15 General Shellfish Sanitation Requirements

- $\underline{\text { Ch. } 16}$ Uniform Physical Plant Equipment and Operation Requirements 
- $\quad$ Ch. 17 Shucker-Packer

- Ch. 18 Shellstock Shipper

- $\quad$ Ch. 19 Reshipper

- $\underline{\text { Ch. } 20}$ Depuration

- Ch. 21 Shellfish Relay

- $\underline{\text { Ch. } 22}$ Retail Shellfish

- Ch. 23 Standards for Closure of Contaminated or Polluted Flats

- Ch. 24 Importation of Live Marine Organisms

- Ch. 25 Lobster and Crab

- Ch. 26 Sea Urchins

- $\quad$ Ch. 27 Sea Cucumbers

- Ch. 28 Marine Worms

- Ch. 29 Seaweed

- Ch. 30 Alewives

- Ch. 31 Horseshoe Crabs

- Ch. 32 Eels

- Ch. 34 Groundfish Regulations

- Ch. 36 Herring Regulations

- Ch. 37 Freshwater Fish Regulations

- Ch. 39 Sturgeon - Minimum Length Limit for Shortnose and Atlantic Sturgeon and Closed Area

- Ch. 40 Smelt

- Ch. 41 Menhaden

- $\underline{\text { Ch. } 42}$ Striped Bass

- Ch. 43 Bluefish Rules

- Ch. 44 American Shad

- Ch. 45 Shrimp Ch. 49 Shellfish Bait Permit

- $\underline{\text { Ch. } 50}$ Spiny Dogfish and Coastal Sharks

- Ch. 55 Gear Restrictions

- Ch. 65 Burnt Island, Living Lighthouse and Facilities

- Ch. 70 Hancock County, Dragging Prohibited in Cable Area

- $\underline{\text { Ch. } 75}$ Protected Resources

- $\underline{\text { Ch. } 80}$ Commercial Pelagic and Anadromous Fishing License

- Ch. 85 Saltwater Fishing Registry

- Ch. 90 Conservation Areas

- Ch. 95 Closed Areas - Due to Pollution

- Ch. 96 Closed Areas - Paralytic Shellfish Poisoning

-

- Ch. 105 Safety Regulations

- Ch. 100 Grievance Procedures for the Handicapped

- Ch. 110 Marine Harvesting Demonstration License 
- Evaluation Criteria:

1.) Has the State enacted development legislation?- (Yes),

2.) Date of formal legislative enactment?- (1983),

3.) Has the State enacted a development act?- (Yes),

4.) If Yes, when was the development act completed?- (N/A),

5.) Has the State completed a development plan?- (Yes),

6.) If Yes, when was the development plan completed?- (1990),

7.) What was the timeframe for completion? - (1 Yr.),

8.) Does the State have a tead agency?"- (Yes),

9.) Which agency is tead agency?"- [Maine Department of Marine Resources (ME DMR),

10.) Does the State have an aquaculture coordinator/Expert contact?- (Yes),

11.) Does the State have an advisory board/council/committee/task force?- (Yes)[Aquaculture Advisory Council/ Shellfish Advisory Council],

12.) If Yes, does the panel still exist?- (N/A),

13.) Has the State enacted more stringent discharge regulation?- (Yes),

14.) What has the state enacted?- [State Waste Discharge Program for Hatcheries],

15.) Has the State enacted more stringent aquatic animal health standards (AAHM)?(Yes),

16.) What is the AAHM regulation?- [State Monitored Shellfish Culture Program],

17.) Does the State have higher education participation?-(Yes),

- Wirth \& Luzar (2000) Regulatory Stringency Value: "11”

- Species Cultured:

Salmon, (Marine) Shellfish, and Trout etc.

- Production Values (2007):

Trout- $\$ 2,718,000$

Other Food fish- $\$ 19,771,000$,

Baitfish- \$211,000,

Crustacean- N/A,

Mollusk-\$3,286,000,

Ornamental-N/A,

Sport fish/ Game fish- N/A,

- Regulatory Agencies:

1.) ME Department of Marine Resources (Lead Agency),

- Commentary:

The state of Maine had profitable production until early 2000's when the pathogen ISA infected Salmon throughout the state and nearby regions, introduced from Norway. USDA through APHIS mandated updated aquatic health measures which resulted in stifled production until recently when the state has finally begun to see more profitable times. 
- Sources:

Diantha Robinson, ME Department of Marine Resources,

P: 1-207-633-9500,

Diantha.Robinson@maine.gov

Marcy Nelson, ME DMR, Division of Ecology and Aquaculture, P: 1-207-633-9502

Marcy.nelson@maine.gov

Maine Department of Marine Resources Administrative Rules, http://www.maine.gov/sos/cec/rules/13/chaps13.htm 
Maryland- (MD)

- Applicable Statutes:

MD Code Agriculture, T. 10 Sub.T. 10, (Seafood \& Aquaculture Development Program), MD Code \$2-106, (Aquaculture Review Council), $\S 10-1001$, (Department of Agriculture Duties), $\S 10-1002$, (Marketing \& Financial Fund), $\S 10-1101$, (Seafood Marketing Advisory Commission), \$10-1301, (MD DOA, Lead Agency Designation), \$10-1302, (Aquaculture Review Council), $\S 10-1303$, (Aquaculture Coordinating Council), \$10-1301 et seq., (University of Maryland, Lead Research Agency), \$5-301, (Financial Assistance), $\$ 5-901$ et seq., (Aquaculture Non-tidal Wetlands Delineation), \$4-205.1, (Nuisance Provisions), \$4-215, (Fisheries Management Program), $\S 4-1103$, (Oyster Management Program), $\S 4-1909$, (Oyster Shell Purchase Program),

MD Code NATRES T.4 SubT.11-A, (Natural Resource Code- Aquaculture), §4-11A-12, (Shellfish Importation Regulation),

- Other Rules \& Regulation:

$-\mathrm{N} / \mathrm{A}$

- Evaluation Criteria:

1.) Has the State enacted development legislation?- (Yes),

2.) Date of formal legislative enactment?- (1987),

3.) Has the State enacted a development act?- (Yes),

4.) If Yes, when was the development act completed?- (1988),

5.) Has the State completed a development plan?- (N/A),

6.) If Yes, when was the development plan completed?-N/A,

7.) What was the timeframe for completion?-N/A,

8.) Does the State have a tead agency?"-(Yes),

9.) Which agency is - $æ$ agency?"

- [-Joint MD Department of Agriculture (MD DOA) \& MD Department of Natural Resources (MD DNR)],

10.) Does the State have an aquaculture coordinator/Expert contact?- (Yes),

11.) Does the State have an advisory board/council/committee/task force?(Yes)- [Aquaculture Review \& Coordinating Council],

12.) If Yes, does the panel still exist?- (N/A),

13.) Has the State enacted more stringent discharge regulation?- (Yes),

14.) What has the state enacted?- [State Monitored Discharge Program],

15.) Has the State enacted more stringent aquatic animal health standards (AAHM)?- (Yes),

16.) What is the AAHM regulation?- [State Monitored Transportation \& Exportation Certification Requirement], 
17.) Does the State have higher education participation?-(Yes),

Wirth \& Luzar (2000) Regulatory Stringency Value: “13”

- Species Cultured:

Trout and oysters, etc.

- Production Values (2007):

Catfish- N/A,

Trout- $\$ 93,000$,

Other Food fish- N/A,

Baitfish-N/A,

Crustacean- $\$ 768,000$,

Mollusk- $\$ 615,000$,

Ornamental-N/A,

Sport fish/ Game fish- N/A

- Regulatory Agencies:

1.) MD Department of Agriculture (MD DOA)- Lead Agency,

2.) MD Department of Natural Resources (MD DNR),

- Commentary:

- It was recently discovered that the State legislature delegated authority to the Department of Natural Resources; which was originally held by the Department of Agriculture.

- Sources:

Karl Roscher, MD Department of Agriculture,

P: $1-410-841-5724$

roschekr@mda.state.md.us 
Massachusetts- (MA)

- Applicable Statutes:

M.G.L.A. 130 §57, (Shellfish Regulation),

$\S 65$, (Animal Report Requirement for Shellfish),

$40 \mathrm{~A} \S$, (Zoning Ordinance Exemption,

- Other Rules and Regulation:

322 MA ADC 15.01, (Fish Regulation)

- Evaluation Criteria:

1.) Has the State enacted development legislation?- (Yes),

2.) Date of formal legislative enactment?- (1995),

3.) Has the State enacted a development act?- (Yes),

4.) If Yes, when was the development act completed?- (1995),

5.) Has the State completed a development plan?- (Yes),

6.) If Yes, when was the development plan completed?- (1995),

7.) What was the timeframe for completion? (1 Yr.),

8.) Does the State have a tead agency?"- (Yes),

9.) Which agency is tead agency?"- [-Joint" MA Department of Agriculture (MA DOA) \& MA Department of Marine Fisheries (MA DMF)],

10.) Does the State have an aquaculture coordinator/Expert contact?-Yes,

11.) Does the State have an advisory board/council/committee/task force?(Yes)- [State Aquaculture Advisory Committee],

12.) If Yes, does the panel still exist?- (N/A),

13.) Has the State enacted more stringent discharge regulation?- (Yes),

14.) What has the state enacted?- [State Discharge Program],

15.) Has the State enacted more stringent aquatic animal health standards (AAHM)?- (Yes),

16.) What is the AAHM regulation?- [State Monitored Shellfish Culture Program]

17.) Does the State have higher education participation?- (Yes),

- Wirth \& Luzar (2000) Regulatory Stringency Value: —XA"

- Species Cultured:

Trout, salmon, oysters, and barramundi etc.

- Production Values (2007):

Catfish- N/A,

Trout- $\$ 3,455,000$,

Other Food fish- $\$ 3,802,000$,

Baitfish- $\$ 1,000$,

Crustacean- $\$ 9,000$,

Mollusk- $\$ 11,176,000$,

Ornamental-N/A, 
Sport fish/ Game fish- N/A,

- Regulatory Agencies:

1.) MA Department of Agriculture Services (MA DOA),

2.) MA Department of Marine Fisheries (MA DMF),

- Commentary:

Massachusetts has a great website that elaborates publications and general regulatory compliance. The State has placed a guidance document for the troubling areas as follows:

1.) BMP's

a. Shellfish Culture,

b. Freshwater Finfish Culture,

2.) Permits,

3.) Operation Specific Compliance,

4.) Industry Education,

- Sources:

Sean Bowen, MA DOA,

P: 1-617-626-1724

Sean.bowen@state.ma.us 
Michigan- (MI)

- Applicable Statutes:

MCLA Ch. 286, (Aquaculture Development)

$\$ 286.872$ et seq., (Lead Agency Designation),

$\$ 286.874$ et seq., (Aquaculture Classification),

$\$ 286.875$ et seq., (Approved Species Listing),

$\$ 286.876$ et seq., (Permits/ Registration),

$\S 286.879$ et seq., (Inspection),

\$286.878, (Unapproved Species Research),

Ch. 287, (Animal Industries Act - Idalth"),

$\$ 287.703$ et seq., (Aquaculture Reference),

$\$ 287.709$, (Michigan DOA Lead Agency),

$\$ 287.707$ et seq. (State Veterinarian),

$\S 287.708$,

$\$ 287.709$,

$\S 287.729 \mathrm{a}$

Ch. 324 (Act 451), (Natural Resources, \& Environmental Protections Act), $\$ 324.413$, $\$ 324.45909$ et seq., (Fish Rearing Propagation), $\$ 324.48702$ et seq., (Exception for MI DNR),

- Other Rules and Regulation:

Fisheries Division Rules: R299.981-299.989, (Importation of Fish \& Eggs),

- Evaluation Criteria:

1.) Has the State enacted development legislation?- (Yes),

2.) Date of formal legislative enactment?-(1996),

3.) Has the State enacted a development act?- (Yes),

4.) If Yes, when was the development act completed?- (1996),

5.) Has the State completed a development plan?- (N/A),

6.) If Yes, when was the development plan completed?-(N/A),

7.) What was the timeframe for completion?- (N/A),

8.) Does the State have a tead agency?"- (Yes),

9.) Which agency is — lad agency?"- [MI Department of Agriculture (MI DOA)],

10.) Does the State have an aquaculture coordinator/Expert contact?- (Yes),

11.) Does the State have an advisory board/council/committee/task force?(N/A),

12.) If Yes, does the panel still exist?- (N/A),

13.) Has the State enacted more stringent discharge regulation?- (Yes),

14.) What has the state enacted?- [State Discharge Permits],

15.) Has the State enacted more stringent aquatic animal health standards (AAHM)?- (Yes),

16.) What is the AAHM regulation?- [State Facility Inspection \& Importation Certification Requirement],

17.) Does the State have higher education participation?- (Yes), 
- Wirth \& Luzar (2000) Regulatory Stringency Value: “6”

- Species Cultured:

- Production Values:

Catfish- $\$ 113,000$

Trout- $\$ 2,122,000$,

Other Food fish- $\$ 1,895,000$,

Baitfish-\$1,046,000,

Crustacean- N/A,

Mollusk-N/A,

Ornamental- \$249,000,

Sport fish/ Game fish- $\$ 349,000$,

- Regulatory Agencies:

1.) MI Department of Agriculture (MI DOA) (Lead Agency),

2.) MI Department of Natural Resources (MI DNR),

- Commentary:

- Missouri aquaculture has the benefit of a tivestock" classification under Chapter 277 for its products. West Virginia could use this designation as it moves forward with its industry development.

- Sources:

Nancy Frank, MI DOA,

P: $1-517-373-1077$

frankn@michigan.gov 
Minnesota- (MN)

- Applicable Statutes:

MN ST §17.46 et seq., (Aquaculture Development Act),

$\$ 17.47$ et seq., (Duties \& Declarations),

$\$ 17.491$ et seq., (Classification),

M.S.A. $\S 13.643$ et seq.,

$\$ 17.494$ et seq., (Permits \& Licensure),

$\S 17.4986$,

$\S 17.4988$,

$\S 17.496$,

$\S 17.497$,

$\S 17.4985$,

$\$ 17.4981$ et seq. ( Subtitle 1: Farm Licensure),

$\S 17.4984$ et seq. (Subtitle 3: Species Listing),

$\S 17.4989$ et seq. (Waste Disposal),

$\S 103 \mathrm{~B} .335(\mathrm{a})(5)$,

$\S 103 \mathrm{G} .2241(5)$.

- Other Rules and Regulation:

$-\mathrm{N} / \mathrm{A}$,

- Evaluation Criteria:

1.) Has the State enacted development legislation?- (Yes),

2.) Date of formal legislative enactment?- (1991),

3.) Has the State enacted a development act?- (Yes),

4.) If Yes, when was the development act completed?- (1991),

5.) Has the State completed a development plan?- (N/A),

6.) If Yes, when was the development plan completed?- (N/A),

7.) What was the timeframe for completion?- (N/A),

8.) Does the State have a tead agency?"- (Yes),

9.) Which agency is — l agency?"- [MN Department of Agriculture (MN DOA),

10.) Does the State have an aquaculture coordinator/Expert contact?- (Yes),

11.) Does the State have an advisory board/council/committee/task force?-

(Yes)-[MN Aquaculture Association Acting Advisory Committee"],

12.) If Yes, does the panel still exist?- (Yes),

13.) Has the State enacted more stringent discharge regulation?- (Yes),

14.) What has the state enacted?- [State Driven NPDES Permit Program],

15.) Has the State enacted more stringent aquatic animal health standards (AAHM)?-(No),

16.) What is the AAHM regulation?- [Follows APHIS AAHM Requirements],

17.) Does the State have higher education participation?-(Yes),

- Wirth \& Luzar (2000) Regulatory Stringency Value: "11" 
- Species Cultured:

Tilapia, Trout, Baitfish, and Game fish etc.

- Production Values(2007):

Catfish- N/A,

Trout- $\$ 692,000$,

Other Food fish- $\$ 127,000$,

Baitfish- $\$ 3,807,000$,

Crustacean- N/A,

Mollusk- N/A,

Ornamental-\$106,000,

Sport fish/ Game fish- $\$ 5,282,000$,

- Regulatory Agencies:

1.) MN Department of Agriculture (Lead Agency),

2.) MN Department of Natural Resources (MN DNR),

- Commentary:

-It was indicated that Minnesota is a tough state to produce aquaculture largely due to is immense regulatory pressure from importation and federal oversight with regards to interstate commerce. Health certification is costly and time consuming and since 1988 relatively low production figures have resulted.

- Sources:

David Weinand, MN Department of Agriculture,

P: 1-651-201-6646

David.weinand@stat.mn.us

Greg Oswald, Oswald Fisheries (Producer Owned),

P:1-507-684-2608

Greg@,oswaldfisheries.com 
Mississippi- (MS)

- Applicable Statutes:

MS ST 49-7-53, (Game Animal Shipment Rules),

49-15-76, (Sale of Game Fish),

69-1-253, (Council on Agricultural Product Disparagement),

69-7-601, (Catfish Marketing Law of 1975 Section),

69-7-602, Đescriptions",

69-7-605 et seq. (Lead Agency Designation),

69-7-611, (Rules/ Regulations),

69-7-612, (Certification/Testing Mandate),

79-22 et seq., (Aquaculture Development Act of 1988),

79-22-2, (Lead Agency Designation),

79-22-7, (Marketing Permits),

79-22-9, (Plant/ Animal Products Permits Regulation),

79-22-15, (Brood stock Rules/ Regulation),

79-22-23, (Leasing/ One-Stop Permits/ Aquaculture Coordinator),

79-22-31, (State Educational Institutions),

79-22-25, (Aquaculture Venture Center),

79-22-23, (Catfish Farming Industry Regulation),

79-22-25, (Tilapia Regulation),

- Other Rules and Regulations:

Title 22: MS DMR Rules (Marine) (2006)

Ch.4: Applicable Regulation to all Aquaculture Operations, (100.01-100.10),

Ch.5: Specific Finfish \& Crustacean Rules, (100-102),

Ch.6: Regulation for Mollusk Aquaculture, (100-102),

Ch.7: Monitoring,

Ch.8: Industry Research,

Ch.9:Penalties,

- Evaluation Criteria:

1.) Has the State enacted development legislation?- (Yes),

2.) Date of formal legislative enactment?- (1975),

3.) Has the State enacted a development act?- (Yes),

4.) If Yes, when was the development act completed?- (1988),

5.) Has the State completed a development plan?- (No),

6.) If Yes, when was the development plan completed?- (No),

7.) What was the timeframe for completion?- (No),

8.) Does the State have a tead agency?"- (Yes),

9.) Which agency is - $\$$ d agency?"- [MS Department of Agriculture (MS DOA)],

10.) Does the State have an aquaculture coordinator/Expert contact?- (Yes),

11.) Does the State have an advisory board/council/committee/task force?-

(Yes)- [Aquaculture Task Force],

12.) If Yes, does the panel still exist?- (No),

13.) Has the State enacted more stringent discharge regulation?- (Yes), 
14.) What has the state enacted?- [State Monitored NPDES Program,

15.) Has the State enacted more stringent aquatic animal health standards (AAHM)?- (Yes),

16.) What is the AAHM regulation?- [State Monitored Importation/Exportation Program for Catfish],

17.) Does the State have higher education participation?- (Yes),

- Wirth \& Luzar (2000) Regulatory Stringency Value: —8

- Species Cultured:

Catfish, oysters, baitfish, and other food and game fish etc.

- Production Values (2007):

Catfish- $\$ 229,400,000$,

Trout- $\$ 1,000$,

Other Food fish- $\$ 648,000$,

Baitfish- $\$ 502,000$,

Crustacean- $\$ 87,000$,

Mollusk- N/A,

Ornamental-\$73,000,

Sport fish/ Game fish- N/A,

- Regulatory Agencies:

1.) MS Department of Agriculture (MS DOA) (Lead Agency),

2.) MS Department of Environmental Quality (MS DEQ),

3.) MS Department of Marine Resources (MS DMR),

4.) MS Department of Wildlife and Fisheries (MS DWF),

- Commentary:

Catfish is King in Mississippi!

- Sources:

Gene Robertson, NASAC Contact

P:1-601-359-1102 
Missouri- (MO)

- Applicable Statutes:

VAMS 275.450, (Aquaculture Marketing Council),

$.450(\mathrm{c})$, (Duties and Goals),

.644.016, (State Discharge Program),

.644.051(4), (General Permits),

.644.051(9), (Site-Specific Permits),

MO ST 275.452, (Mandatory Fees/Duties),

.454-.455, (Aquaculture Marketing Fund),

277.024, (Aquaculture Classification under Title 17),

- Other Rules and Regulation:

$-\mathrm{N} / \mathrm{A}$,

- Evaluation Criteria:

1.) Has the State enacted development legislation?- (Yes),

2.) Date of formal legislative enactment?- (1989),

3.) Has the State enacted a development act?- (Yes),

4.) If Yes, when was the development act completed?- (1989),

5.) Has the State completed a development plan?- (Yes),

6.) If Yes, when was the development plan completed?- (1991),

7.) What was the timeframe for completion?- (N/A),

8.) Does the State have a tead agency?"- (Yes),

9.) Which agency is — lad agency?"- [MO Department of Agriculture (MO DOA)],

10.) Does the State have an aquaculture coordinator/Expert contact?- (Yes),

11.) Does the State have an advisory board/council/committee/task force?(Yes)- [Industry Advisory Council],

12.) If Yes, does the panel still exist?- (Yes),

13.) Has the State enacted more stringent discharge regulation?-(Yes),

14.) What has the state enacted?- [State Water Discharge Permit Requirement],

15.) Has the State enacted more stringent aquatic animal health standards (AAHM)?- (No),

16.) What is the AAHM regulation?- [VHS Mandates by APHIS],

17.) Does the State have higher education participation?-(Yes),

- Wirth \& Luzar (2000) Regulatory Stringency Value: “1”

- Species Cultured:

Catfish, trout, goldfish, koi, baitfish, pike, and prawns etc. 
- Production Value(2007):

Catfish- $\$ 2,028,000$,

Trout- $\$ 3,910,000$,

Other Food fish- N/A,

Baitfish-\$596,000,

Crustaceans- $\$ 5,000$,

Mollusk- N/A,

Ornamental-N/A,

Sport fish- $\$ 457,000$

- Regulatory Agencies:

1.) MO Department of Agriculture (MO DOA) (Lead Agency),

- Commentary:

Missouri lacks a state owned processor which hinders industry development. State expert contact is an extremely knowledgeable source.

- Sources:

Bart Hawcroft, MO DOA,

P: $1-573-526-6666$

Bart.hawcroft@mda.mo.gov 
Nebraska- (NE)

- Applicable Statutes:

Neb. Rev. ST §2-3804, (Aquaculture Classification),

\$2-3815, (Agriculture Development Promotional Program),

\$2-5001, (Agriculture Development Act)

$\S 2-5003$, (State Aquaculture Board),

$\S 2-5005$, (Board Duties),

$\S 2-5006$,

\$37-203, (Game \& Parks Code- Definitions),

$\$ 37-204$, (Permits),

$\$ 37-416$,

$\$ 37-469$, (Reporting Moderated),

$\$ 37-470$, (Quarantine Provisions),

\$37-471, (Sale Allowed Under Permit),

$\S 37-4106$, (Non-Resident Licensure),

- Other Rules and Regulation:

$-\mathrm{N} / \mathrm{A}$,

- Evaluation Criteria:

1.) Has the State enacted development legislation?- (Yes),

2.) Date of formal legislative enactment?- (1987),

3.) Has the State enacted a development act?- (Yes),

4.) If Yes, when was the development act completed?- (1993),

5.) Has the State completed a development plan?- (Yes),

6.) If Yes, when was the development plan completed?- (1994),

7.) What was the timeframe for completion?- (N/A),

8.) Does the State have a tead agency?"- (Yes),

9.) Which agency is tead agency?"- [NB Department of Agriculture (NB DOA)],

10.) Does the State have an aquaculture coordinator/Expert contact?- (Yes),

11.) Does the State have an advisory board/council/committee/task force?(Yes)- [State Aquaculture Board],

12.) If Yes, does the panel still exist?- (N/A),

13.) Has the State enacted more stringent discharge regulation?- (No),

14.) What has the state enacted?- [Follows Federal NPDES Guidelines- Most production is small static restocking],

15.) Has the State enacted more stringent aquatic animal health standards (AAHM)?-(Yes),

16.) What is the AAHM regulation?- [State Facility Inspection Requirements],

17.) Does the State have higher education participation?- [Yes],

- Wirth \& Luzar (2000) Regulatory Stringency Value: +10" 
- Species Cultured:

Catfish, Trout, Baitfish, Yellow Perch, and Ornamentals etc.

- Production Value(2007):

Catfish- $\$ 96,000$,

Trout-\$2,231,000,

Other Food Fish-\$50,000,

Baitfish- $\$ 16,000$,

Crustaceans- N/A,

Mollusk-N/A,

Ornamental- $\$ 14,000$,

Sport fish- $\$ 1,413,000$

- Regulatory Agency:

1.) NB Department of Agriculture (NB DOA) (Lead Agency),

2.) NB Department of Environmental Quality (NB DEQ),

3.) NB Game and Parks Commission (NB GFC),

- Commentary:

- It was expressed that traditionally Nebraska is a beef state. This notion overshadows any surge in promotion for aquaculture. Approximately, eight years ago, the State industry saw a surge in yellow perch production, but has since dropped off. The lack of centralized processor for the state has caused financial hardship among the small food fish production sector. Also, competition from overseas continues constrain Nebraska's development. All-in-all, the quality is said to be there!

- Sources:

Steve Martin, NB DOA,

P: $1-402-471-4876$

Steve.martin@nebraska.gov 
New Hampshire- (NH)

- Applicable Statutes:

N.H. Rev. Stat §21:34-a, (Aquaculture Classification),

$\S 211: 62-\mathrm{e},($ Development Legislation),

$\S 206: 8(1)$,

§211:62-e(11a), (Lead Agency, NH-Fish \& Game Commission),

\$211:62-e(iii) et seq., (Licensure/ Permitting Overview),

$\S 214: 2(1)$, Licensure Requirement under NH Fish \& Game Code),

\$487.34(ii), (NH Health Tidal Waters/ Shellfish Protection Program),

- Other Rules and Regulation:

$-\mathrm{N} / \mathrm{A}$,

- Evaluation Criteria:

1.) Has the State enacted development legislation?- (Yes),

2.) Date of formal legislative enactment?- (1978),

3.) Has the State enacted a development act?- (Yes),

4.) If Yes, when was the development act completed?- (1992),

5.) Has the State completed a development plan?- (N/A),

6.) If Yes, when was the development plan completed?- (N/A),

7.) What was the timeframe for completion?- (N/A),

8.) Does the State have a tead agency?"-(Yes),

9.) Which agency is - lad agency?"- (NH Fish and Game Commission (NHFGC)],

10.) Does the State have an aquaculture coordinator/Expert contact?- (Yes),

11.) Does the State have an advisory board/council/committee/task force?(Yes)- [Interagency Cooperative Shellfish Program],

12.) If Yes, does the panel still exist?- (N/A),

13.) Has the State enacted more stringent discharge regulation? - (N/A),

14.) What has the state enacted?- (N/A),

15.) Has the State enacted more stringent aquatic animal health standards (AAHM)?- (N/A),

16.) What is the AAHM regulation?- (N/A),

17.) Does the State have higher education participation?- (Yes),

- Wirth \& Luzar (2000) Regulatory Stringency Value: +3”

- Species Cultured:

Catfish, Ornamentals, Shellfish, and varied Sport fish etc.

- Regulatory Agencies:

1.) NH Fish and Game Commission (NH FGC) (Lead Agency),

2.) NH Department of Agriculture (NH DOA), 
- Production Value (2007):

Catfish- $\$ 95,675,000$

Crustaceans- $\$ 592,000$

Ornamental- $\$ 299,000$

Sport fish- $\$ 2,677,000$

- Commentary:

- The state of New Hampshire originally codified the majority of its aquaculture focused legislation in 1978. Almost 20 years later, it amended a significant portion of its law to fit the needs of the industry. Having promulgated legislation prior to 1980 makes the State very progressive from a historical standpoint.

- Sources:

Dr. Ken La Valley, NH Sea Grant/ University of NH, NASAC Contact

P: 1-603-862-4343

Ken.LaValley@unh.edu 
New Jersey- (NJ)

- Applicable Statutes:

N.J.S.A. $\S 4: 1-6$ et seq.,

(L.1997, c.312, §1), (N.J. Aquaculture Association),

(L.1997, c. 236, §25),

$\S 4: 27-(1-24)$ et seq., (Aquaculture Development Legislation, enacted 1997),

$\S 4: 27-3$, (Task Force for Aquaculture Development Act),

$\S 4: 27-4$, (Office of Aquaculture Coordination),

$\S 4: 27-5$, (Council Advisory),

$\S 4: 27-6$, (Lead Agency),

$\S 4: 27-7$, (Memorandum Interagency Agreement),

$\S 4: 27-12$, (Inland Wetland Protection),

$\S 4: 27-13$, (Coastal Wetlands Protection),

$\S 4: 27-10$, (Rule/ Regulations Review),

$\S 4: 27-18$, (Aquatic Waste Management Plans),

$\S 4: 27-19$, (Animal Waste Management Plans),

$\S 4: 27-20$, (Planning/ Zoning Ordinances),

$\S 4: 27-22$, (Promotion Investment in Aquaculture),

N.J.S.A. T.23, Ch.2B, (Marine Fisheries Code),

N.J. ADC §7:25-24.1,

$\S 50: 1-18(\mathrm{a}, \mathrm{b}, \mathrm{d})$,

$\S 50: 2-2$,

$\S 50: 2-12-18$, (Shellfish Industry Regulation),

$\S 58: 1 \mathrm{~A}$ et seq. (Water Supply Provisions),

$\S 58: 1 \mathrm{~A}-13$, (NJ Water Management Plan),

§5:10A-3, (Water Pollution Control Provisions),

$\S 58: 10 \mathrm{~A}-6$, (Waste Discharge Regulation),

$\S 58: 10 \mathrm{~A}-7$, (Discharge Permits),

- Other Rules and Regulation:

$-\mathrm{N} / \mathrm{A}$,

- Evaluation Criteria:

1.) Has the State enacted development legislation?- (Yes),

2.) Date of formal legislative enactment?- (1997),

3.) Has the State enacted a development act?- (Yes),

4.) If Yes, when was the development act completed?- (1997),

5.) Has the State completed a development plan?- (Yes),

6.) If Yes, when was the development plan completed?- (1995),

7.) What was the timeframe for completion?- (3Yrs.),

8.) Does the State have a lead agency?"- (Yes),

9.) Which agency is — lad agency?"- [NJ Department of Agriculture (NJ DOA)],

10.) Does the State have an aquaculture coordinator/Expert contact?- (Yes),

11.) Does the State have an advisory board/council/committee/task force?(Yes)- [Aquaculture Development Task Force], 
12.) If Yes, does the panel still exist?- (Yes),

13.) Has the State enacted more stringent discharge regulation?- (Yes),

14.) What has the state enacted?- [State waste discharge permit],

15.) Has the State enacted more stringent aquatic animal health standards (AAHM)?- (Yes),

16.) What is the AAHM regulation?- [Transportation and importation certification requirement],

17.) Does the State have higher education participation?- (Yes),

- Wirth \& Luzar (2000) Regulatory Stringency Value: -N/A"

- Species Cultured:

Catfish, Mollusks, and Ornamentals etc.

- Regulatory Agencies:

1.) NJ Department of Agriculture (NJ DOA) Lead Agency,

2.) NJ Department of Environmental Protection (NJ DEP),

- Production Value (2007):

Catfish- $\$ 3,000$,

Trout-N/A,

Other Food Fish-N/A,

Baitfish-N/A,

Crustaceans- N/A,

Mollusks- $\$ 4,504,000$,

Ornamental- $\$ 1,115,000$,

Sport fish- N/A,

- Commentary:

- New Jersey is a state that mandates reports to be directed to be the governor and legislature as part of an annual review program meant to ensure adequate bookkeeping." West Virginia needs to consider mandating a reporting-type record basis.

- Sources:

Joe Myers, NJ DOA,

P: 1-609-984-2502

Joseph.myers@ag.state.nj.us 
New York- $(N Y)$

- Applicable Statutes:

NY AGRI \& MKTS §293 (2004), (Marketing of Agriculture Products),

ENVIR CONSER §13-0105(7), (Endorsement for Industry Growth), \$24-0701(3), (Permits for Freshwater Aquaculture), \$25-0401(3), (Tidal Wetlands Regulation),

- Other Rules and Regulation:

- Evaluation Criteria:

1.) Has the State enacted development legislation?- (N/A),

2.) Date of formal legislative enactment?- (N/A),

3.) Has the State enacted a development act?- (N/A),

4.) If Yes, when was the development act completed?- (N/A),

5.) Has the State completed a development plan?- (N/A),

6.) If Yes, when was the development plan completed?- (N/A),

7.) What was the timeframe for completion?- (N/A),

8.) Does the State have a lead agency?"- (Yes),

9.) Which agency is tead agency?"- [New York Department of Agriculture \& Industries (NY DOA)],

10.) Does the State have an aquaculture coordinator/Expert contact?-Yes,

11.) Does the State have an advisory board/council/committee/task force?(N/A),

12.) If Yes, does the panel still exist?- (N/A),

13.) Has the State enacted more stringent discharge regulation?- (N/A),

14.) What has the state enacted?- (N/A),

15.) Has the State enacted more stringent aquatic animal health standards (AAHM)?- (N/A),

16.) What is the AAHM regulation?- (N/A),

17.) Does the State have higher education participation?- (N/A),

- Wirth \& Luzar (2000) Regulatory Stringency Value: 44"

- Species Cultured:

Bluegill, Carp, Trout, Catfish, Minnows, Koi, Bass, Crawfish, and Perch etc.

- Regulatory Agencies:

1.) NY Department of Agriculture \& Industries (Lead Agency),

- Production Value (2007):

Catfish- $\$ 9,000$,

Trout- $\$ 6,144,000$,

Other Food Fish- N/A,

Baitfish- $\$ 169,000$,

Crustaceans- N/A, 
Mollusks- \$7,408,000,

Ornamental-\$2,013,000,

Sport fish- \$687,000,

- Commentary:

- Sources:

Philip Hulbert, NY DOA,

P: 1-518-402-8894

pxhulbert@gw.dec.state.ny.us 
North Carolina- (NC)

- Applicable Statutes:

NC ST $§ 106$ et seq., (NC Aquaculture Development Act),

$\S 106-759$, (Lead Agency),

\$106-760, (Advisory Board),

\$106-761, (Facility Registration \& Approved Species Listing),

\$106-581:1(4), (Aquaculture Classification),

\$106-762, (Aquatic Fish Disease Management Regulation),

\$113-168.4, (Fish Sales Pursuant to Licensure),

$\S 113-202$, (Shellfish Leasing Program),

$\S 113-182.1$ (c1-e), (Fishery Management Plan),

\$113-200, (Fishery Resource Grant Program),

\$113-202.1, (Water Column Leasing Program; extended for shellfish),

$\S 113-203$, (Transport lawful for oysters and clams),

$\$ 120-70.60$ et seq. (Joint Legislative Commission on Seafood and Aquaculture),

§143B-279.8, (Coastal Habitat Protection Plan),

- Other Rules and Regulation:

$-\mathrm{N} / \mathrm{A}$,

- Evaluation Criteria:

1.) Has the State enacted development legislation?- (Yes),

2.) Date of formal legislative enactment?- (1989),

3.) Has the State enacted a development act?- (Yes),

4.) If Yes, when was the development act completed?- (1989),

5.) Has the State completed a development plan?- (Yes),

6.) If Yes, when was the development plan completed?- (1988),

7.) What was the timeframe for completion?- (1yr),

8.) Does the State have a lead agency?"- (Yes),

9.) Which agency is — $æ$ d agency?"- [NC Department of Agriculture (NC DOA)],

10.) Does the State have an aquaculture coordinator/Expert contact?- (Yes),

11.) Does the State have an advisory board/council/committee/task force?-

(Yes)- [Aquaculture Advisory Board/ Joint Legislative Commission on Seafood \& Aquaculture],

12.) If Yes, does the panel still exist?- (Yes),

13.) Has the State enacted more stringent discharge regulation?- (Yes),

14.) What has the state enacted?- [State NPDES Program/ Cold Water Production Requirements],

15.) Has the State enacted more stringent aquatic animal health standards (AAHM)?- (Yes),

16.) What is the AAHM regulation?- [State Monitored Importation Certification Program].

17.) Does the State have higher education participation?- (Yes),

- Wirth \& Luzar (2000) Regulatory Stringency Value: -4" 
- Species Cultured:

Trout, catfish, oysters, clams, bass, crawfish, baitfish, and ornamentals etc.

- Regulatory Agencies:

1.) NC Department of Agriculture (Lead Agency),

- Production Value(2007):

Catfish- $\$ 9,000$,

Trout- $\$ 6,144,000$,

Other Food Fish-\$15,354,000,

Baitfish-\$169,000,

Crustaceans- $\$ 312,000$,

Mollusk- $\$ 1,009,000$,

Ornamental- $\$ 177,000$,

Sport fish- $\$ 74,000$,

- Commentary:

- North Carolina markets itself as -aquaculture friendly." This has been proven to stimulate development of aquaculture related activities. West Virginia should begin to heavily market its industry in an effort to seek out economic development opportunities that ultimately results in a sustained effort to promote the longevity of the industry.

- Sources:

Debra Sloan, NC DOA,

P: $1-828-524-1264$

Debrasloan@earthlink.net 
Ohio- $(\mathrm{OH})$

- Applicable Statutes:

R.C. $\$ 1.61$, (Aquaculture Classification), §303.01, (Redevelopment Blighted Areas for Agriculture Purpose), $\$ 1533.301$, (General Permit Requirements), $\S 1533.632$, (Aquaculture Code), $\S 2807.81(\mathrm{~b})(3)$, (Food Disparagement Clause),

- Other Rules and Regulation:

$-\mathrm{N} / \mathrm{A}$,

- Evaluation Criteria:

1.) Has the State enacted development legislation?- (Yes),

2.) Date of formal legislative enactment?- (N/A),

3.) Has the State enacted a development act?- (No),

4.) If Yes, when was the development act completed?- (No),

5.) Has the State completed a development plan?- (Yes),

6.) If Yes, when was the development plan completed?- (2010),

7.) What was the timeframe for completion?- (2 Yrs.),

8.) Does the State have a Head agency?"- (Yes),

9.) Which agency is tead agency?"- [OH Department of Agriculture (OH DOA)],

10.) Does the State have an aquaculture coordinator/Expert contact?- (Yes),

11.) Does the State have an advisory board/council/committee/task force?(Yes)- [Aquaculture Development Task Force],

12.) If Yes, does the panel still exist?- (No)- [Disbanded Upon Completion of ADP],

13.) Has the State enacted more stringent discharge regulation?- (No- In Development Phase),

14.) What has the state enacted?- [State Follows Federal NPDES Guidelines],

15.) Has the State enacted more stringent aquatic animal health standards (AAHM)?- (Yes),

16.) What is the AAHM regulation?

- [State Monitored Plant wide Certification Requirement].

17.) Does the State have higher education participation?-(Yes),

- Wirth \& Luzar (2000) Regulatory Stringency Value: 8”

- Species Cultured:

Catfish, trout, baitfish, ornamentals, and sport fish etc.

- Regulatory Agencies:

1.) $\mathrm{OH}$ Department of Agriculture (Lead Agency),

2.) $\mathrm{OH}$ Department of Natural Resources, Division of Wildlife (OH DNR),

3.) $\mathrm{OH}$ Department of Natural Resources; Division of Water (OH DNR), 
- Production Value(2007):

Catfish- $\$ 189,000$,

Trout- $\$ 1,723,000$,

Other Food Fish-\$753,000,

Baitfish-\$924,000,

Crustaceans- N/A,

Mollusk- N/A,

Ornamental- $\$ 166,000$,

Sport fish- $\$ 2,455,000$,

- Commentary:

- Sources:

Lindsey Mandau, OH DOA,

P: 1-614-325-0735

lmandau@agri.ohio.gov

Laura, Tiu, Ph.D., OSU Aquaculture Specialist,

P:1-800-297-2072, ext. 121

Tiu.2@osu.edu 
Oklahoma- (OK)

- Applicable Statutes:

29 OKL. ST. Ann. §4-102, (Historical Perspective),

$\S 4-105-115$, (Minnow Licensure),

\$7-602, (Importation/Exportation Requirements),

2 OKL. ST. Ann. §2-4(16)(a)(3), (NPDES Requirements),

$\S 3-85(\mathrm{~h})(1)(\mathrm{c})$, (OK DEQ Authority),

§6-311, (State Licensure Regulation),

$\S 8-41: 16$, (OK DEQ Jurisdiction over Environment),

- Other Rules and Regulation:

Title 35-Oklahoma Department of Agriculture, Food, and Forestry Administrative Code:

Chapter 44 et seq., (Agriculture Environmental Permitting and AGPDES),

Section 35:44-1-1 Purpose and jurisdiction

Chapter 50 et seq., (Aquaculture-Private Commercial Production),

Section 35:50-1-30

Initial licensing requirements

Section 35:50-1-31 Renewal licensing requirements

Section 35:50-1-32 Inspections

Section 35:50-1-33 Annual report

Section 35:50-1-34 Facility expansion requirements

Section 35:50-1-35 Record keeping

Section 35:50-1-36 Emergency notifications

Section 35:50-1-37 Technical services

Section 35:50-1-38 Complaints

Title 800-Department of Wildlife Conservation:

Chapter 15 et seq., (Commercial Harvest Rules; Aquatic Species),

Section 800:15-11-1 Purpose

Section 800:15-11-2 List of restricted aquatic species

Section 800:15-11-3 Inspection authority

Section 800:15-11-4 Penalties

Chapter 20 et seq. (Restriction on Aquatic Species Introduction),

Subchapter 1 Restricted Exotic Fish

Subchapter 2 Fish Introductions in Waters of the State

Subchapter 3 Noxious Aquatic Plants

Subchapter 4 Aquatic Nuisance Species Restrictions

- Evaluation Criteria:

1.) Has the State enacted development legislation?- (Yes),

2.) Date of formal legislative enactment?- (1970- 2002

3.) Has the State enacted a development act?-(N/A),

4.) If Yes, when was the development act completed?-N/A, 
5.) Has the State completed a development plan?- (Yes),

6.) If Yes, when was the development plan completed?- (2001),

7.) What was the timeframe for completion?-(N/A)

8.) Does the State have a tead agency?"-(Yes),

9.) Which agency is tead agency?"- [OK Department of Agriculture (OK DOA)],

10.) Does the State have an aquaculture coordinator/Expert contact?(Yes),

11.) Does the State have an advisory board/council/committee/task force?- (Yes),-

12.) If Yes, does the panel still exist?- (N/A),

13.) Has the State enacted more stringent discharge regulation?- (Yes),

14.) What has the state enacted?- [Agriculture Pollutant Discharge Program (AGPDES)],

15.) Has the State enacted more stringent aquatic animal health standards (AAHM)?- (Yes),

16.) What is the AAHM regulation? - [State Monitored Importation Certification Requirement].

17.) Does the State have higher education participation?- (Yes),

- Wirth \& Luzar (2000) Regulatory Stringency Value: -9"

- Species Cultured:

Catfish, Paddlefish, crawfish, frogs, shrimp, bass, tilapia, trout, salmon, and baitfish etc.

- Regulatory Agencies:

1.) OK Department of Agriculture (OK DOA) (Lead Agency),

2.) OK Department of Environmental Quality (OK DEQ),

3.) OK Department of Wildlife Conservation (OK DWC),

- Production Value(2007):

Catfish- $\$ 442,000$,

Trout- N/A,

Other Food Fish- N/A,

Baitfish- $\$ 64,000$,

Crustaceans- N/A,

Mollusk- N/A,

Ornamental- $\$ 742,000$,

Sport fish- $\$ 1,616,000$,

- Commentary:

The lack of a processor has placed financial burden on the producers of the state of

Oklahoma. It has been suggested that the placement of such infrastructure is eminent to allow for adequate industry growth for the state.

- Sources: 
Janice Montgomery, OK DOA,

P: 1-405-522-6125

Janice.montgomery@oda.state.ok.us

Dr. Rod Hall, OK State Veterinarian, OK DOA

1-405-522-6126 
Pennsylvania- $(P A)$

- Applicable Statutes:

3 Pa.C.S.A. $\S 4201$ et seq. (PA Aquaculture Development Legislation (1998)), $\S 4202$, (Added by 1998. Oct 16, P.L. 768, No. 94 §),

$\S 4211$, (Aquaculture Classification), $\S 4216$, (Advisory Committee), $\S 4218$, (Development Account (fiscal), $\S 4217$, (Biennial Survey Mandate), 35 P.S. §6018.103, (Solid Waste Management Provisions), 7 Pa.C.S.A. §106:1, (Development Plan),

- Other Rules and Regulation:

7 Pa. Code $\S 106.52$. (Application).

$\S 106.61$. (Grant amount).

$\S 106.63$. (Application).

$\S 106.64$. (Review of applications).

$\S 106.65$. (Processing of applications).

$\S 106.82$. (Limitations).

$\S 106.84$. (Information to be solicited).

\$46.247. (Shell stock identification).

12 Pa. Code \$73.112a. (Agricultural enterprises).

$25 \mathrm{~Pa}$. Code $\S 92 \mathrm{a} .31$. (Aquaculture projects).

$58 \mathrm{~Pa}$. Code $\S 63.17$. (Importation and sale of hard clams).

$\$ 63.45$, (Tagging, branding, marking and fin clipping of fish.),

$\S 71.3$, (Closed system propagation),

\$79.11, (Introduction).,

\$79.12. (Color morphs of native species).,

$\S 79.3$, (Season and daily possession limits).,

\$79.8, (Artificial propagation and dealers of live reptiles and amphibians).,

61 Pa. Code §155.2, (Family farm corporation exemption).,

- Evaluation Criteria:

1.) Has the State enacted development legislation?- (Yes),

2.) Date of formal legislative enactment?- (1998),

3.) Has the State enacted a development act?- (Yes),

4.) If Yes, when was the development act completed?- (1998),

5.) Has the State completed a development plan?- (N/A),

6.) If Yes, when was the development plan completed?- (N/A),

7.) What was the timeframe for completion?- (N/A)

8.) Does the State have a tead agency?"-(Yes), 
9.) Which agency is tead agency?"- [PA Department of Agriculture (PA DOA)],

10.) Does the State have an aquaculture coordinator/Expert contact?(Yes),

11.) Does the State have an advisory board/council/committee/task force?- (Yes)-[PA Advisory Committee],

12.) If Yes, does the panel still exist?- (Yes),

13.) Has the State enacted more stringent discharge regulation?- (No),

14.) What has the state enacted?- [Follows Federal NPDES Mandates Until State Driven Program Completed],

15.) Has the State enacted more stringent aquatic animal health standards (AAHM)?- (Yes),

16.) What is the AAHM regulation?- [State Monitored Plant wide Certification Requirement].

17.) Does the State have higher education participation?- (Yes),

- Wirth \& Luzar (2000) Regulatory Stringency Value: - 7

- Species Cultured:

Trout, carp, and baitfish etc.

- Regulatory Agencies:

1.) PA Department of Agriculture (PA DOA) (Lead Agency),

2.) PA Department of Environmental Protection (PA DEP),

3.) PA Department of Natural Resources (PA DNR),

- Production Value(2007):

Catfish- $\$ 51,000$,

Trout- $\$ 28,408,000$,

Other Food Fish-\$2,904,000,

Baitfish-\$687,000,

Crustaceans- N/A,

Mollusk- N/A,

Ornamental- $\$ 990,000$,

Sport fish- $\$ 11,366,000$,

- Commentary:

- Pennsylvania has now implemented a -ne-stop shop" permit structure after the state reclassified its waste designation. The reclassification from aquacultural to agricultural allows production enterprises (producers) to practice less intensive disposal measures achieving a more profitable business structure.

- Sources:

Charlie Conklin, PA DOA,

P: 1-570-460-0804

charlieconklin@verizon.net 
Rhode Island- (RI)

- Applicable Statutes:

Gen. Laws 1956, §2-23-4(a), (Aquaculture classification), $\S 20-1-3$, (Aquaculture Product Possession), $\S 20-2-45$ (c), (Aquaculture Coordinator),

RI ST. T.20, Ch.10, (R.I. Aquaculture Development Legislation), \$20-10-1.1, (Biosecurity Board \& CRMC), $\$ 20-10-2(3)$, (Lead Agency), \$20-10-3, (CRMC Permits \& Grants), \$20-10-4, (Permit Application), $\S 20-10-5$, (Approval Guidelines), $\S 20-10-6$, (Lease Program), \$20-10-(7\& 9), (Fees/ Restrictions), $\S 20-10-8$, (Performance Board Requirements), \$20-10-11, (RI DEM Rules \& Regulations), $\S 20-10-12$, (Licensure), $\S 20-10-15$, (Delegated Inspection Authority), \$22-7.4-78, (Blount Aquaculture Research Facility), §46-23-1, (CRMC Rules),

- Other Rules and Regulation:

- N/A,

- Evaluation Criteria:

1.) Has the State enacted development legislation?- (Yes),

2.) Date of formal legislative enactment?- (1982-2001),

3.) Has the State enacted a development act?- (N/A),

4.) If Yes, when was the development act completed?- (N/A),

5.) Has the State completed a development plan?- (N/A),

6.) If Yes, when was the development plan completed?- (N/A),

7.) What was the timeframe for completion?- (N/A),

8.) Does the State have a tead agency?"- (Yes),

9.) Which agency is tead agency?"- [RI Department of Environmental Management (RI DEM)],

10.) Does the State have an aquaculture coordinator/Expert contact?(Yes),

11.) Does the State have an advisory board/council/committee/task force?- (Yes)- [Coastal Resources Management Council]

12.) If Yes, does the panel still exist?- (Yes),

13.) Has the State enacted more stringent discharge regulation?-(Yes),

14.) What has the state enacted?- [State Monitored Performance Permit System -Encompassing Waste Disposal],

15.) Has the State enacted more stringent aquatic animal health standards (AAHM)?- (Yes), 
16.) What is the AAHM regulation?-[State Monitored Plant wide Certification Requirement].

17.) Does the State have higher education participation?- (Yes),

- Wirth \& Luzar (2000) Regulatory Stringency Value: - 10

- Species Cultured:

Striped Bass, Shellfish, etc.

- Regulatory Agencies:

1.) RI Department of Environmental Management (RI DEM) (Lead Agency),

2.) RI Department of Fish and Wildlife (RI DFW),

- Production Value(2007):

Catfish- N/A,

Trout- N/A,

Other Food Fish- N/A,

Baitfish- N/A,

Crustaceans- N/A,

Mollusk- N/A,

Ornamental- N/A,

Sport fish- N/A,

- Commentary:

- Sources:

David Alves, Coastal Resources Management Council,

P: 1-401-783-3370

P: 1-978-281-9216

David.alves@noaa.gov 


\section{South Carolina- (SC)}

- Applicable Statutes:

Code 1976, §46-1-10, (Aquaculture Classification),

$\S 46-51-10$, (Aquaculture Permit Office Enactment (1988)),

Act. No. 587 (1988), (Lead Agency),

$\S 46-14-40$, (Land Disturbance Exemption),

\$48-39-80, (Coastal Zone Management Program (CZM)),

$\S 50-1-10$, (Property of State Designation: 1993 Act. No. 181, §1251),

$\S 50-18-210$, (SC Aquaculture Enabling Act),

§50-18-215, (SC DNR Permitting/ Law Enforcement),

$\S 50-18-225$, (Permit Application for Licensure),

§50-18-230, (Freshwater Culture Regulation),

$\S 50-18-250$, (Mandatory Inspection Regulation),

§50-18-270, (Importation Regulation),

$\S 50-18-245$, (Non-indigenous Requirement),

$\S 50-18-260$, (Permit Transfer Program),

$\S 50-18-255$, (Wholesale Licensure),

- Other Rules and Regulation:

- N/A,

- Evaluation Criteria:

1.) Has the State enacted development legislation?- (Yes),

2.) Date of formal legislative enactment?- (1986- 2003),

3.) Has the State enacted a development act?- (Yes),

4.) If Yes, when was the development act completed?- (1988),

5.) Has the State completed a development plan?- (Yes),

6.) If Yes, when was the development plan completed?- (1989),

7.) What was the timeframe for completion? - (4 Yrs.),

8.) Does the State have a lead agency?"- (Yes),

9.) Which agency is lead agency?"- [Joint"- SC Department of Natural Resources (SC DNR) \& SC Department of Agriculture (SC DOA)],

10.) Does the State have an aquaculture coordinator/Expert contact?(Yes),

11.) Does the State have an advisory board/council/committee/task force?- (Yes)- [SC Aquaculture Association]

12.) If Yes, does the panel still exist?- (Yes),

13.) Has the State enacted more stringent discharge regulation?- (Yes),

14.) What has the state enacted?-[State Monitored EZM" NPDES Program],

15.) Has the State enacted more stringent aquatic animal health standards (AAHM)?- (Yes),

16.) What is the AAHM regulation?- [State Mandatory Facility Inspection Requirements],

17.) Does the State have higher education participation?- (Yes), 
- Wirth \& Luzar (2000) Regulatory Stringency Value: “8”

-

- Species Cultured:

Catfish, Trout, Baitfish, Ornamentals, and Sport fish etc.

- Regulatory Agencies:

1.) SC Department of Agriculture (SC DOA) (Lead Agency),

2.) SC Department of Natural Resources (SC DNR) (Lead Agency),

3.) SC Wildlife and Marine Resources Department (SC WMD),

- Production Value(2007):

Catfish- $\$ 189,000$,

Trout- $\$ 1,723,000$,

Other Food Fish-\$753,000,

Baitfish-\$924,000,

Crustaceans- N/A,

Mollusk- N/A,

Ornamental- $\$ 166,000$,

Sport fish- $\$ 2,455,000$,

- Commentary:

- South Carolina is a state that utilizes the -one-stop-shop" permit system that allows for more efficient regulatory compliance.

- Sources:

Chad Truesdale, SC DOA,

P: $1-803-734-2218$

ctruesd@scda.sc.gov 
South Dakota- (SD)

- Applicable Statutes:

SDCL §20-10A-1, (Product Liability Disparagement),

- Other Rules and Regulation:

- N/A,

- Evaluation Criteria:

1.) Has the State enacted development legislation?- (Yes),

2.) Date of formal legislative enactment?- (1994),

3.) Has the State enacted a development act?- (N/A),

4.) If Yes, when was the development act completed?- (N/A),

5.) Has the State completed a development plan?- (N/A),

6.) If Yes, when was the development act completed?- (N/A),

7.) What was the timeframe for completion?- (N/A),

8.) Does the State have a tead agency?"- (Yes),

9.) Which agency is tead agency?"- [SD Department of Natural Resources (SD DNR_],

10.) Does the State have an aquaculture coordinator/Expert contact?(Yes),

11.) Does the State have an advisory board/council/committee/task force?- (N/A),

12.) If Yes, does the panel still exist?- (N/A),

13.) Has the State enacted more stringent discharge regulation?- (Yes,

14.) What has the state enacted?- [State Monitored NPDES Program],

15.) Has the State enacted more stringent aquatic animal health standards (AAHM)?-(Yes),

16.) What is the AAHM regulation?- [State Monitored Importation Certification Requirement],

17.) Does the State have higher education participation?- (Yes),

- Wirth \& Luzar (2000) Regulatory Stringency Value: “8”

- Species Cultured:

-Trout, Tilapia, and Flathead Minnows, etc.

- Regulatory Agencies:

1.) SD Department of Natural Resources, (SD DNR) (Lead Agency),

2.) SD Department of Agriculture (SD DOA),

3.) SD Department of Fish and Game (SD DFG),

- Production Value(2007):

Catfish- N/A,

Trout-\$380,000,

Other Food Fish- N/A, 
Baitfish- N/A,

Crustaceans- N/A,

Mollusk- N/A,

Ornamental- $\$ 1,334,000$,

Sport fish- $\$ 2,455,000$,

- Commentary:

- South Dakota has varied production. Much of the culture that occurs in the Black Hills" area is rainbow trout by private pond for food fish markets. Eastern and central state production is mostly occurring for recreational restocking purposes. Interesting point to note is for a state claimed to possess a regulatory stringency of 8 ": only one statute was found during the extensive review and after on review of the state administrative rules.

- Sources:

Sarah Jorgensen, SD DOA,

P: 1-605-773-5436

Sarah.jorgensen@,state.sd.us

John Lott, SD DFG,

P: 1-605-773-6508

Garland Erbley,

P: $1-605-773-3352$

Geno Adams, SD DFG,

P: $1-605-773-4501$

Kelly Buscher

P: 1-605-773-3351 
Tennessee- (TN)

- Applicable Statutes:

TN ST §43-33-101 (TN Aquaculture Policy Act of 1991: Added by 1991 Pub.Acts, c.401§1),- (Later Repealed by 2008Pub.Acts.c.622, §2),

$\S 43-33-102$, (Advisory Board),

$\S 43-33-103$, (Board Powers/Duties),

§43-33-104, (Plans/ Specifications),

$\S 43-33-105$,

$\S 43-33-12.6$, (Fish Farming: Hybrid Striped Bass),

T.C.A. §53-1-102(17), (Catfish Legislation),

\$67-5-1604, (Agriculture Income Designation (Tax Code)),

§68-221-803(1), (Discharge Regulation for Water Reuse Technology),

- Other Rules and Regulation:

TN Wildlife Resources Agency, Chapter 1660-1-26-(.01-.04) et seq., (Fish

Farming, Catch-Out Operations, and Bait Dealer Rules),

- Evaluation Criteria:

1.) Has the State enacted development legislation?- (Yes),

2.) Date of formal legislative enactment?- (1991),

3.) Has the State enacted a development act?- (Yes),

4.) If Yes, when was the development act completed?- (1991),

5.) Has the State completed a development plan?- (Yes),

6.) If Yes, when was the development plan completed?- (1994),

7.) What was the timeframe for completion?- (1 Yr.),

8.) Does the State have a lead agency?"- (Yes),

9.) Which agency is tead agency?"- [TN Department of Agriculture (TN DOA)],

10.) Does the State have an aquaculture coordinator/Expert contact?(Yes),

11.) Does the State have an advisory board/council/committee/task force?- (Yes)- [Advisory Board],

12.) If Yes, does the panel still exist?- (N/A),

13.) Has the State enacted more stringent discharge regulation?-(Yes),

14.) What has the state enacted?- [State Driven NPDES Program],

15.) Has the State enacted more stringent aquatic animal health standards (AAHM)?- (Yes),

16.) What is the AAHM regulation?- [State Monitored General" Certification Requirement],

17.) Does the State have higher education participation?- (Yes),

- Wirth \& Luzar (2000) Regulatory Stringency Value: -1’1

- Species Cultured:

Catfish, Trout, and Tilapia etc. 
- Regulatory Agencies:

1.) TN Department of Agriculture, (TN DOA)- (Lead Agency),

2.) TN Department of Environmental Protection and Conservation, (TN DEPC),

- Production Value(2007):

Catfish- $\$ 235,000$,

Trout- $\$ 3,222,000$,

Other Food Fish- N/A,

Baitfish- N/A,

Crustaceans- N/A,

Mollusk- N/A,

Ornamental- \$32,000,

Sport fish- $\$ 880,000$,

- Commentary:

- The industry expert eluded that the lack of a state-owned, centralized processor was the reason the state freshwater prawn production culture failed and it moved towards a mariculture focus.

- Sources:

Dan Strasser, TN DOA

P: 1-615-837-5160

Pick.TN@tn.gov

David K. Amonett, Morgan County Extension Agent \& Director"

University of Tennessee Institute of Agriculture,

P: $1-423-346-3000$

Damonett1@tennessee.edu

Tennessee Wildlife Resources Agency, Rules and Regulation Pertaining to Aquaculture, http://state.tn.us/sos/rules/1660/1660-01/1660-01-26.pdf 
Texas- $(T X)$

- Applicable Statutes:

TX AGRIC §11.005(b)(2), (Aquaculture Classification), $\S 134.002$, (Lead Agency),

TX AGRIC T.6, SubT.A, Ch. 134, (Texas Aquaculture Development Legislation), $\$ 134.004$, (Inter Agency Cooperation), $\S 134.005$, (TX PWD Regulation), $\$ 134.020$, (Exotic Species Listing), $\$ 134.011$, (Licensure), $\$ 134.031$, (MOA Relationship), $\S 134.013$, (CZM Shrimp Culture), $\$ 134.018$, (Licensure for Specific Species), $\S 134.019$, (Redfish/ Seatrout Provisions), $\S 134.021$, (Federal Grant Access),

TX CIV PRAC \& REM §96.001, (False Disparagement Protection),

V.T.C.A. Education Code $\$ 143.003$, (Higher Education Promotion Provisions), Government Code $\$ 418.073$, (Emergency Disaster),

TX Parks \& Wild \$47.009, (Wholesale Bait Dealer Exemption), $\$ 47.010$, (Truck Licensure Requirement), $\$ 47.011$, (Conditional Retail Licensure), $\S 47.014$, (Bait Dealer's Licensure), $\S 66.007$, (Exotic Harmful Species to Aquaculture),

TX Water $\$ 26.0345$, (Discharge Permits), $\$ 26.0292$, (Fees),

- Other Rules and Regulation:

TX Administrative Code Title IV, $§ 1.41$ et seq., (Private Real Property Rights), $\$ 1.208$ et seq., (Shrimp Marketing Assistance), $\S 1.330$ et seq., (MOU- TX NRC, TX PWD, \& TX

DOA),

$\$ 16.2$ et seq., (License Application), Title XXV, §241.54 et seq., (Molluscan Shellfish Aquaculture), $\S 241.55$ et seq., (Land Based Aquaculture),

- Evaluation Criteria:

1.) Has the State enacted development legislation?- (Yes),

2.) Date of formal legislative enactment?- (1989),

3.) Has the State enacted a development act?- (Yes),

4.) If Yes, when was the development act completed?- (1989),

5.) Has the State completed a development plan?- (N/A),

6.) If Yes, when was the development plan completed?-(N/A),

7.) What was the timeframe for completion?- (N/A),

8.) Does the State have a lead agency?"- (Yes),

9.) Which agency is tead agency?"- [TX Department of Agriculture (TX DOA)], 
10.) Does the State have an aquaculture coordinator/Expert contact?(Yes),

11.) Does the State have an advisory board/council/committee/task force?- (Yes)- [Aquatic Animal Health Board/ Aquaculture Advisory Board],

12.) If Yes, does the panel still exist?- (N/A),

13.) Has the State enacted more stringent discharge regulation?- (Yes),

14.) What has the state enacted?- [State Monitored Waste Water Discharge Program],

15.) Has the State enacted more stringent aquatic animal health standards (AAHM)?- (Yes),

16.) What is the AAHM regulation?- [State Monitored Certification Requirement],

17.) Does the State have higher education participation?- (Yes),

- Wirth \& Luzar (2000) Regulatory Stringency Value: -5"

- Species Cultured:

Catfish, Baitfish, Shrimp, Redfish, and Sea Trout etc.,

- Regulatory Agencies:

1.) TX Department of Agriculture (TX DOA)-(Lead Agency),

2.) TX Natural Resource Conservation Commission (TX NRCC),

3.) TX Animal Health Commission (TX AHC),

4.) TX Parks and Wildlife Department (TX PWD),

- Production Value(2007):

Catfish- $\$ 12,123,000$,

Trout- N/A,

Other Food Fish-\$14,692,000,

Baitfish-\$398,000,

Crustaceans- $\$ 12,501$,

Mollusk- N/A,

Ornamental- $\$ 892,000$,

Sport fish- $\$ 4,182,000$,

- Commentary:

- During the research phase it was found that much of the state code pertaining to finfish culture had been repealed; the reason was never found.

- Sources:

Joe Benavides, TX DOA,

P: $1-512-463-7401$

Joe.benavides@texasagriculture.gov 
Utah- (UT)

- Applicable Statutes:

UT ST §4-37-101, (Utah Aquaculture Act), $\S 4-37-102$, (Aquaculture Classification), \$4-37-103-104, (Rules/ Regulations, Lead Agency), $\S 4-37-106$, (Memorandum of Understanding), $\S 4-37-107$, (Advisory Board), \$4-37-109, (Prohibited Activities), $\S 4-37-110$, (Inspection of Facilities), $\S 4-37-201$, (Facility Certifications), §4-37-203, (Transportation Requirement), $\S 4-37-204$, (Sale), $\S 4-37-301$, (Certification/ Transfer), $\S 4-37-302$, \$4-37-303, (Transportation to Restocking), $\S 4-37-304$, (Sale), $\S 4-37-305$, (Licensure), $\S 4-37-401$, (Certification Requirements), $\S 4-37-402$, (Documentation for Importation of Species), $\S 4-37-501$, (Health Approval), \$4-37-502, (Inspection), \$23-15-10, (Private Fishpond Requirements), \$23-19-1, (Taking; Tags), §23-15-10, (Exemption from §501, Health Approval),

- Other Rules and Regulation:

UT Administrative Code R657-16-1-14 et seq., (Aquaculture \& Fish Stocking), R58-17-1-20 et seq., (Aquaculture \& Aquatic Animal Health), R657-59-1-17 et seq., (Private Fish Pond Rules),

- Evaluation Criteria:

1.) Has the State enacted development legislation?- (Yes),

2.) Date of formal legislative enactment?- (1953),

3.) Has the State enacted a development act?- (Yes),

4.) If Yes, when was the development act completed?- (1994),

5.) Has the State completed a development plan?- (Yes),

6.) If Yes, when was the development plan completed?- (1994),

7.) What was the timeframe for completion?- (N/A),

8.) Does the State have a tead agency?"- (Yes),

9.) Which agency is tead agency?"- [UT Department of Agriculture (UT DOA)],

10.) Does the State have an aquaculture coordinator/Expert contact?(Yes),

11.) Does the State have an advisory board/council/committee/task force?- (Yes)- [Aquaculture Advisory Board/ Fish Health Policy Board], 
12.) If Yes, does the panel still exist?- (No- Repealed),

13.) Has the State enacted more stringent discharge regulation?- (N/A),

14.) What has the state enacted?- (N/A),

15.) Has the State enacted more stringent aquatic animal health standards (AAHM)?-(Yes),

16.) What is the AAHM regulation?- [State Mandated Facility Inspection \& Health Management Certification Requirement],

17.) Does the State have higher education participation?- (Yes),

- Wirth \& Luzar (2000) Regulatory Stringency Value: —XA"

- Species Cultured:

Catfish and Trout etc.

- Regulatory Agencies:

1.) UT Department of Agriculture (UT DOA) (Lead Agency),

2.) UT Department of Natural Resources (UT DNR),

- Production Value(2007):

Catfish- N/A,

Trout- $\$ 4,036,000$,

Other Food Fish- N/A,

Baitfish- N/A,

Crustaceans- N/A,

Mollusk- N/A,

Ornamental- N/A,

Sport fish- N/A,

- Commentary:

- Utah is not associated as a major aquaculture producing state; with that said, nor it is known to have a longstanding industry, statutory-wise. It was not until the research phase of this project occurred, that it found, Utah has been acknowledging aquaculture at least since 1953. Normal industry acknowledgment by state legislatures have been associated following the passage of the National Aquaculture Policy Act in 1980; like Hawaii, Utah's progressive agriculture nature pre-dates other states, yet it not considered a major producer based on production numbers.

$-$

- Sources:

Kent Hauck, UT DOA,

P: $1-801-528-7025$

khauck@utah.gov

Utah Division of Administrative Rules, Search Aquaculture", http://www.rules.utah.gov/search/UACsearchresults.htm?cx $=013817919410579482056 \%$ 3Ayakwgxkxsoa\&cof=FORID\%3A10\&ie=UTF-

$8 \& q=$ aquaculture \&siteurl=www.rules.utah.gov\%2Fpublicat $\% 2$ Fcode.htm $\# 850$ 
Vermont- $(V T)$

- Applicable Statutes:

6 V.S.A. $\$ 1154(\mathrm{a}),($ Testing of Cultured Fish),

10V.S.A. $§ 5207(b),(V T D O A / V T D F W$ authority to enforce testing),

- Other Rules and Regulation:

$-\mathrm{N} / \mathrm{A}$

- Evaluation Criteria:

1.) Has the State enacted development legislation?- (Yes),

2.) Date of formal legislative enactment?- (1993),

3.) Has the State enacted a development act?- (No),

4.) If Yes, when was the development act completed?- (No),

5.) Has the State completed a development plan?- (No),

6.) If Yes, when was the development plan completed?- (No),

7.) What was the timeframe for completion?- (N/A),

8.) Does the State have a lead agency?"- (Yes),

9.) Which agency is tead agency?"- [-Joint"- VT Department of Agriculture (VT DOA) and VT Department of Fish and Wildlife (VT DFW),

10.) Does the State have an aquaculture coordinator/Expert contact?(Yes),

11.) Does the State have an advisory board/council/committee/task force- (No),

12.) If Yes, does the panel still exist?- (No),

13.) Has the State enacted more stringent discharge regulation?- (No),

14.) What has the state enacted?- [Follows Federal NPDES Mandate],

15.) Has the State enacted more stringent aquatic animal health standards (AAHM)?- (Yes),

16.) What is the AAHM regulation?- [State Mandated Pathogen Testing for Live Specimens],

17.) Does the State have higher education participation?- (Yes),

- Wirth \& Luzar (2000) Regulatory Stringency Value: N/A"

- Species Cultured:

Trout, Tilapia, Baitfish, Ornamentals, and Sport fish for Restocking Purposes etc.

- Regulatory Agencies:

1.) VT Department of Agriculture (Lead Agency),

2.) VT Department of Fish and Wildlife (Lead Agency),

- Production Value(2007):

Catfish- N/A,

Trout- N/A,

Other Food Fish- N/A, 
Baitfish-N/A,

Crustaceans- N/A,

Mollusk- N/A,

Ornamental- N/A,

Sport fish- N/A,

- Commentary:

- Minimal statutory record can be paired with a legislative history full of gapped information.

- Sources:

Thomas Jones, VT DFW,

P: $1-802-241-3708$

Tom.jones@state.vt.us 
Virginia- $(V A)$

- Applicable Statutes:

VA Code Ann. \$3.2-108, (Aquaculture Promotion Chapter), $\$ 3.2-400$, (Aquaculture Classification),

VA ST T.3.2, SubT.II Pt. Ch.26, (Aquaculture Advisory Board), \$3.2-2602, (Lead Agency),

VA ST §28.2-245, (Fisheries Grant Access),

$\$ 28.2-246$, (Advisory Board for Grant Program),

$\$ 28.2-520$, (Shellfish Culture Regulation),

$\S 28.2-501$, (Licensure),

$\$ 28.2-603$, (Oyster Production Areas for Aquaculture),

\$28.2-603.1-613, (Oyster Leasing Program),

\$28.2-1600-1623, (Water Column Leasing Program),

- Other Rules and Regulation:

2VAC5-20-20, (Previous and current use, and exceptions),

2VAC5-20-30, (Conservation of land resources; management and prod),

2VAC5-405-10, (Definitions),

2VAC5-585-410, (Shell stock identification),

4VAC15-330-190, (Trout artificially raised for sale),

4VAC15-360-20, (Taking minnows and chubs for sale),

4VAC20-200-30, (Reports required)

4VAC20-252-170, (Aquaculture of striped bass; permit required),

4VAC20-252-180, (Water supply; outfall),

4VAC20-252-190, (Acquisition of fish, fingerlings, fry, and eggs),

4VAC20-252-200, (Inspection of facilities; diseased fish),

4VAC20-252-210, (Sale, records, importation, release

4VAC20-260-30, (Minimum cull size),

4VAC20-335, (Pertaining to On-Bottom Shellfish Aquaculture),

4VAC20-335-10, (Purpose),

4VAC20-336-20, (Discussion),

4VAC20-336-30, (Procedures),

4VAC20-336-40, (Authorization and conditions),

4VAC20-510-33, (Exceptions to possession limits and minimum size),

4VAC20-510-35, (Aquaculture of cobia; permit required),

4VAC20-510-37, (Sale, records, importation, release),

4VAC20-610-20, (Definitions),

4VAC20-610-25, (Oyster and Clam Aquaculture permit requirements),

4VAC20-610-60, (Mandatory harvest reporting),

4VAC20-610-65, (Noncompliance),

4VAC20-1020-30, (Moratorium),

4VAC20-1090-30, (License fees),

4VAC20-1130-50, (Special conditions),

4VAC20-1230-30, (Public health and warm water harvest restrictions),

4VAC20-1250-30, (Shellfish dentification), 
9VAC25-31-150, (Aquaculture projects),

9VAC25-740-90, (Minimum standard requirements for reuses of reclaim),

12VAC5-421-410, (Shell stock identification)

- Evaluation Criteria:

1.) Has the State enacted development legislation?- (Yes),

2.) Date of formal legislative enactment?- (1992),

3.) Has the State enacted a development act?- (Yes),

4.) If Yes, when was the development act completed?- (1992),

5.) Has the State completed a development plan?- (Yes),

6.) If Yes, when was the development plan completed?- (1995),

7.) What was the timeframe for completion? - (2 Yrs.),

8.) Does the State have a lead agency?"- (Yes),

9.) Which agency is tead agency?"- [VA Department of Agriculture (VA DOA)],

10.) Does the State have an aquaculture coordinator/Expert contact?(Yes),

11.) Does the State have an advisory board/council/committee/task force?- (Yes)- [VA Marine Resources Commission/ Aquaculture Association],

12.) If Yes, does the panel still exist?- (Yes),

13.) Has the State enacted more stringent discharge regulation?- (Yes),

14.) What has the state enacted?- [State Promoted NPDES Program],

15.) Has the State enacted more stringent aquatic animal health standards (AAHM)?- (Yes),

16.) What is the AAHM regulation?-[State Monitored General" Health Management Certification Program],

17.) Does the State have higher education participation?- (Yes),

- Wirth \& Luzar (2000) Regulatory Stringency Value: "8"

- Species Cultured:

- Striped Bass, Soft shelled crabs, oysters, trout, and little neck clams, tilapia, etc.

- Regulatory Agencies:

1.) VA Department of Agriculture (Lead Agency),

- Production Value(2007):

Catfish- $\$ 17,000$,

Trout- $\$ 3,358,000$,

Other Food Fish- N/A,

Baitfish- N/A,

Crustaceans- \$669,000,

Mollusk- \$36,948,000,

Ornamental- N/A,

Sport fish- N/A, 
- Commentary:

- The expert was extremely helpful in navigating the complexities of the state industry. Marine production predominates, while freshwater production does still occur. In the early 1990's production for hybrid striped bass was the big species for the state, now the demand for this food fish has leveled off.

- Sources:

T. Robins Buck, VA DOA,

P: 1-804-371-6094

Robins.buck@vdacs.virginia.gov

Virginia Adminstrative Codes Search Aquaculture"--http://leg1.state.va.us/000/lst/LS215889.HTM 
Washington- (WA)

- Applicable Statutes:

WA ST T.15, Ch.15.85, (Washington State Aquaculture Marketing Chapter),

$\$ 15.85 .010$, (Legislative Declarations),

$\$ 15.85 .020$, (Cultured Species Listing),

$\$ 15.85 .030$, (Lead Agency),

$\S 15.85 .040$, (Rulemaking),

WA ST §16.36, (Animal Health Care),

$\S 16.36 .010$, (Quarantine Measures),

$\$ 16.36 .040$, (Inspection \& Permitting Rules),

$\S 16.36 .050$, (Importation \& Transportation Oversight),

$\S 16.36 .045$,

$\S 16.36 .080$, (Mandatory Disease Reporting to WADFW),

$\S 16.36 .084$,

$\S 43.143 .005$, (Ocean Resource Management Program),

$\$ 43.143 .030$, (Permitting/ Draft Plan),

$\S 43.372 .005$, (Marine Waters \& Planning Management Provisions),

$\$ 43.372 .040$, (Comprehensive Marine Plan),

\$77.12.020, (Shellfish Regulation),

§77.65.020, (Licensure Exemption),

$\$ 77.95 .010$, (Salmon Regulation),

West. R.C.W.A. §28B.20.475, (Geoduck SeaGrant Research Program), $\S 79.135 .100$, (Leasing Program),

- Other Rules and Regulation:

WAC 16-603-0101, (Aquaculture Identification Requirements), 246-282-080, (Shellfish Act),

270-77-010-082 et seq., (Aquaculture Disease Control Rules),

RCW 75.58.010-040 et seq., (Disease Inspection \& Control for Aquatic Farmers),

- Evaluation Criteria:

1.) Has the State enacted development legislation?-(Yes),

2.) Date of formal legislative enactment?- (N/A),

3.) Has the State enacted a development act?- (Yes),

4.) If Yes, when was the development act completed?- (N/A),

5.) Has the State completed a development plan?- (N/A),

6.) If Yes, when was the development act completed?- (N/A),

7.) What was the timeframe for completion?- (N/A),

8.) Does the State have a tead agency?"- (Yes),

9.) Which agency is tead agency?"- [WA Department of Agriculture (WA DOA)],

10.) Does the State have an aquaculture coordinator/Expert contact?(Yes),

11.) Does the State have an advisory board/council/committee/task force?- (N/A), 
12.) If Yes, does the panel still exist?- (N/A),

13.) Has the State enacted more stringent discharge regulation?- (Yes),

14.) What has the state enacted?- [State NPDES Permit Required (finfish culture)],

15.) Has the State enacted more stringent aquatic animal health standards (AAHM)?- (No),

16.) What is the AAHM regulation?- [State Monitored Certification following APHIS Requirements],

17.) Does the State have higher education participation?- (Yes),

- Wirth \& Luzar (2000) Regulatory Stringency Value: —XA"

- Species Cultured:

-Geoduck, Salmon, Trout, etc.

- Regulatory Agencies:

1.) WA Department of Agriculture (WA DOA) (Lead Agency),

2.) WA Department of Fish and Wildlife (WA DFW),

- Production Value(2007):

Catfish- N/A, Trout- $\$ 21,848,000$, Other Food Fish-\$43,047,000,

Baitfish- N/A,

Crustaceans- N/A,

Mollusk- $\$ 85,201,000$,

Ornamental- $\$ 116,000$,

Sport fish- $\$ 8,910,000$,

- Commentary:

- It was indicated by the state expert that the greatest barrier to industry development or success is the convoluted permit structure the state implements. Ultimately long wait periods regarding permits during the application process hinders industry entry. Washington state is the largest exporter of trout eggs in the continental U.S.

- Sources:

Dan Swecker, WA Fish Growers Association,

P: $1-360-273-5890$

dans@,wfga.net

Washington State Administrative Code, Search, aquaculture regulation", http://apps.leg.wa.gov/wac/ 
West Virginia- (WV)

- Applicable Statutes:

W.Va. Code $§ 19-32$ et seq., (West Virginia Development Legislation (2010)), §19-32-4, (Lead Agency), $\S 19-32-5$, (Advisory Board),

WV ST §22-15-22, (Solid Waste Management),

§22-26-1, (Water Resources Protection \& Management Act),

- Other Rules and Regulation:

Agriculture - 61-23-1-11 et seq., (WV Aquaculture Farm Rules), 61-23A-1-22 et seq., (WV Fish Processing Rules), 61-23B-1-9 et seq., (WV Shellfish Rules), Animals Rules), 61-23D-1-7 et seq., (WV Inspection of Nontraditional Domesticated

61-27-1-3 et seq., (WV BMP's for Land Application of Waste Products from Aquaculture Facilities Rules),

- Evaluation Criteria:

1.) Has the State enacted development legislation?- (Yes),

2.) Date of formal legislative enactment?- (1999- 2010),

3.) Has the State enacted a development act?- (Yes),

4.) If Yes, when was the development act completed?- (2010),

5.) Has the State completed a development plan?- (No),

6.) If Yes, when was the development plan completed?- (No),

7.) What was the timeframe for completion?- (N/A),

8.) Does the State have a lead agency?"- (Yes)

9.) Which agency is tead agency?- [WV Department of Agriculture (WV DOA)],

10.) Does the State have an aquaculture coordinator/Expert contact?(Yes),

11.) Does the State have an advisory board/council/committee/task force?- (Yes)- [Advisory Board],

12.) If Yes, does the panel still exist?- (Yes),

13.) Has the State enacted more stringent discharge regulation?- No- In Development Process),

14.) What has the state enacted?- [State Developing NPDES for Agriculture Enterprises],

15.) Has the State enacted more stringent aquatic animal health standards (AAHM)?- (No- In development phase),

16.) What is the AAHM regulation?- [State currently requires facility inspection and certification measures],

17.) Does the State have higher education participation?- (Yes),

- Wirth \& Luzar (2000) Regulatory Stringency Value: “12” 
- Species Cultured:

-Trout, Catfish, Hybrid Striped \& Largemouth Bass, Salmon, Carp, Minnows, etc.

- Regulatory Agencies:

1.) WV Department of Agriculture (WV DOA)-(Lead Agency),

2.) WV Department of Natural Resources (WV DNR),

3.) WV Department of Environmental Protection (WV DEP)

- Production Value(2007):

Catfish- N/A,

Trout-\$2,402,000,

Other Food Fish- N/A,

Baitfish- N/A,

Crustaceans- N/A,

Mollusk- N/A,

Ornamental- N/A,

Sport fish- N/A,

- Commentary:

- West Virginia has potential to develop its aquaculture industry. A regulatory structure newly created will allow for adequate growth if the industry can sustain a pro-development focus. The lack of a development plan may hinder progress, but current efforts to draft and promulgate the next step in the process in the works. The state should invest in a processor to handle food fish. The usage of post-mine reclamation waters may create a profitable -niche" marketing strategy for the state as access to East coast markets makes increasing production economically feasible.

- Sources:

Rob Nichols, WV DOA (State Aquaculture Coordinator),

P: 1-304-558-3594

rnichols@ag.state.wv.us

Dr. Kenneth Semmens, West Virginia University Extension Specialist,

P: 1-304-239-2657

Ken.Semmens@mail.wvu.edu 
Wisconsin-(WI)

- Applicable Statutes:

W.S.A. 29.181, (Aquaculture is Agriculture Designation),

36.11(36) et seq., (Aquaculture Demonstration Facility),

91.01(a)(5) et seq., (Farmland Preservation Code),

93.01(1b)\&(1d) et seq., (Lead Agency Designation),

93.46(1-3) et seq., (Cooperative Regulatory Agreement),

- Other Rules and Regulation:

WIS. ADMIN. CODE (NR) 40.02(30) et seq., (Non-native fish regulation),

109.07 et seq., (Invasive and Nonnative Aquatic Plants), 182.075(1p) et seq., (Groundwater Standards), 214.02(1) et seq., (Waste Regulation Applicability),

- Evaluation Criteria:

1.) Has the State enacted development legislation?-(Yes),

2.) Date of formal legislative enactment?- (1999),

3.) Has the State enacted a development act?- (N/A),

4.) If Yes, when was the development act completed?- (N/A),

5.) Has the State completed a development plan?- (Yes),

6.) If Yes, when was the development plan completed?- (1988),

7.) What was the timeframe for completion?- (2 Yrs.),

8.) Does the State have a tead agency?"- (Yes)

9.) Which agency is — læd agency?- [WI Department of Agriculture (WI DOA)],

10.) Does the State have an aquaculture coordinator/Expert contact?- (Yes),

11.) Does the State have an advisory board/council/committee/task force?- (Yes)[Advisory Board],

12.) If Yes, does the panel still exist?- (Yes),

13.) Has the State enacted more stringent discharge regulation?- No- In Development Process),

14.) What has the state enacted?- [State Developing NPDES for Agriculture Enterprises],

15.) Has the State enacted more stringent aquatic animal health standards (AAHM)?(No- In development phase),

16.) What is the AAHM regulation?- [State currently requires facility inspection and certification measures],

17.) Does the State have higher education participation?- (Yes),

- Wirth \& Luzar (2000) Regulatory Stringency Value: -1"

- Species Cultured:

Trout, Salmon, Perch, and Walleye etc. 
- Regulatory Agencies:

1.) WI Department of Agriculture (WI DOA) (Lead Agency),

2.) WI Department of Natural Resources (WI DNR),

- Production Value(2007):

Catfish- N/A,

Trout- $\$ 2,402,000$,

Other Food Fish- N/A,

Baitfish- N/A,

Crustaceans- N/A,

Mollusk- N/A,

Ornamental- N/A,

Sport fish- N/A,

- Commentary:

- The Wisconsin Aquaculture Association avidly promotes the fish products produced within the State. This is a creative marketing scheme normally undertaken by state Departments of Agriculture. The website is very user-friendly!

- Sources:

Wisconsin Aquaculture Association

Cindy Johnson, Secretary/ Treasurer

P-1-715-373-2990

cindy@wisconsinaquaculture.com

website- $\mathrm{http}$ ://www.wisconsinaquaculture.com/index.cfm 